Mariane Silveira de Sousa-Baena

\title{
EvoluÇão e desenvolvimento de gavinhas em Bignonieae (Bignoniaceae)
}

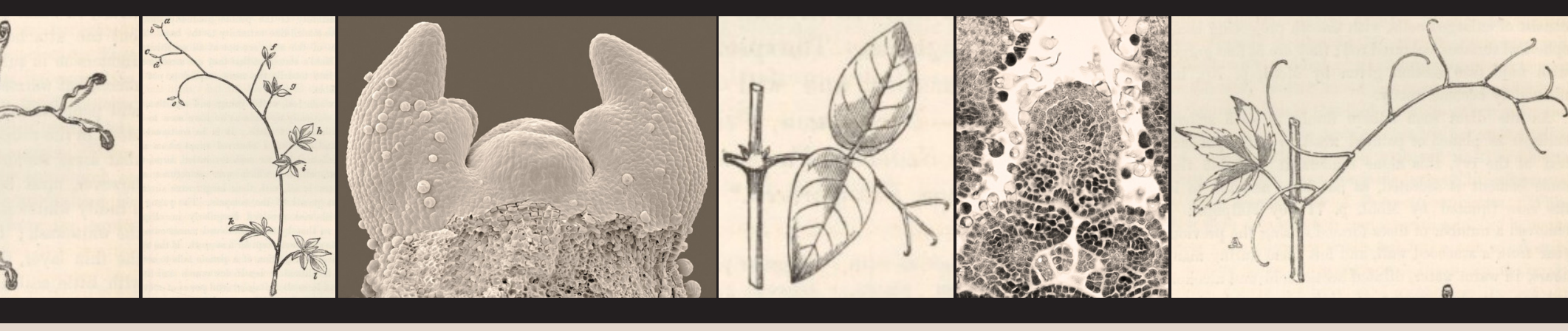

São Paulo 


\section{Mariane Silveira de Sousa-Baena}

\section{Evolução E DesenVolvimento DE gavinhas Em Bignonieae (Bignoniaceae)}




\section{Mariane Silveira de Sousa-Baena}

\section{Evolução E DesenVolvimento DE gavinhas em Bignonieae (Bignoniaceae)}




\section{Mariane Silveira de Sousa-Baena}

\section{Evolução E DESENVOLVIMENTo DE Gavinhas Em Bignonieae (Bignoniaceae)}

Tese apresentada ao Instituto de Biociências da Universidade de São Paulo, para a obtenção de Título de Doutor em Ciências, na Área de Botânica.

Orientadora: Profa. Dra. Lúcia G. Lohmann Co-orientadora: Profa. Dra. Neelima Roy Sinha 
SOUSA-BAENA, MARIANE SILVEIRA DE

2011

\section{EVOLUÇÃO E DESENVOLVIMENTO DE GAVINHAS EM BIGNONIEAE (BIGNONIACEAE)}

183 páginas

Tese (Doutorado) - Instituto de Biociências da Universidade de São Paulo.

Departamento de Botânica.

1. Gavinhas foliares 2. Desenvolvimento 3. Evolução 4. Folhas compostas

5. Bignoniaceae 6. SHOOTMERISTEMLESS 7. LEAFY/FLORICAULA 8. genes ARP

I. Universidade de São Paulo. Instituto de Biociências. Departamento de Botânica.

\section{Comissão JUlgadora:}

$\operatorname{Prof}(a) \cdot \operatorname{Dr}(a)$.

$\operatorname{Prof}(\mathrm{a}) \cdot \operatorname{Dr}(\mathrm{a})$.

Prof(a). Dr(a).

$\operatorname{Prof}(a) . \operatorname{Dr}(a)$.

Profa. Dra. Lúcia G. Lohmann 
Dedico esta tese, com muito amor e gratidão, ao Eduardo por ter me dado todo apoio, incentivo e ter sonhado junto comigo ... 
"Morphological innovations of land plants have profoundly changed the terrestrial biosphere. Plant innovations have affected global geochemistry, hydrology, atmospheric composition and the evolution of other biota. The study of plant evolution can therefore be viewed as a study of the way in which nucleotide changes have affected the functioning of the planet. These innovations result from alterations in the original developmental pathways responsible for the relatively simple construction of early land plants...." 
Segue o teu destino,

Rega as tuas plantas,

Ama as tuas rosas.

O resto é a sombra

De árvores alheias.

Fernando Pessoa 


\section{Agradecimentos}

Ao Conselho Nacional de Desenvolvimento Científico e Tecnológico - CNPQ, pela bolsa de doutorado concedida, e á Coordenação de Aperfeiçoamento de Pessoal de Nível Superior CAPES, pela bolsa PDEE concedida, a qual financiou meus estudos na UC Davis, Estados Unidos, por um ano.

Á Universidade de SãoPaulo e ao Instituto de Biociências, em especial: ao Laboratório de Sistemática Vegetal, ao Laboratório de Anatomia Vegetal e ao Laboratório de Genética Molecular de Plantas - GATE, por terem me recebido para que eu pudesse desenvolver as diversas partes deste trabalho.

Á UCDavis - Universidade da California-campus Davis, em especial ao laboratório da Dra. Neelima Sinha, que me recebeu e financiou o meu trabalhos por dois anos.

Á MORPH - Molecular and Organismic Research in Plant History, por ter me concedido um auxilio que financiou parte do meu trabalho na UCDavis.

Á American Society of Plant Biologists - ASPB, por conceder o auxílio que me permitiu participar da conferência "Plant Biology 2009, Hawaii", e ter minha primeira experiência numa conferência internacional.

Á minha orientadora, Lucia Garcez Lohmann, por ter compartilhado seu conhecimento de maneira tão generosa, por ter acreditado no meu trabalho, me incentivado e me ajudado de várias formas nesses quatro anos de trabalho. Com a sua competência, generosidade e trabalho incansável a Lúcia abre caminhos para que muitos possam crescer profissionalmente e será sempre um exemplo a ser seguido....por isso, por toda sua contribuição a Botânica, pela seriedade e brilho com que desenvolve a sua pesquisa, eu sempre a admirarei. A oportunidade que ela me deu de desenvolver esse projeto mudou minha carreira na Botânica pra sempre, me trouxe experiências profissionais e de vida muito enriquecedoras e por isso serei pra sempre grata.

Á minha co-orientadora, Neelima Roy Sinha, por ter me recebido em seu laboratório e me dado a oportunidade de aprender tanto, por ter tido tanta paciência com as minhas dificuldades com a língua inglesa logo que cheguei em Davis e também por ter me dado a oportunidade de permanecer por mais tempo desenvolvendo meus trabalhos em seu laboratório na UCDavis ao me contratar através da Universidade.

Aos colaboradores da minha tese, Magdalena Rossi e Andrew Doust, pelos conselhos, revisões e correções de projeto. Em especial á Magda, que me orientou durante o treinamento que fiz no GATE, me ensinando desde as coisas mais básicas como o design de primers até abrindo as portas de sua casa para que eu pucesse coletar Cuspidaria convoluta do seu lindo caramanchão. 
Á Teresa Terrazas Salgado pelo incentivo. Todo o interesse que a Tereza demonstrou pelos meu trabalhos ja concluídos e por meu projeto de doutorado em andamento me inspiraram muito pra seguir em frente.

Ao Marcelo Carnier Dornelas, por compartilhar seu conhecimento de maneira tão generosa através de suas disciplinas de pós-graduação, transmitindo não só o conhecimento teórico, mas também o amor e entusiasmo que sente pelo que faz.

Aos professores do Laboratório de Anatomia Vegetal Veronica Angyalossy, Nanuza Luiza de Menezes, Gladys Flávia de Albuquerque Melo de Pinna e Gregorio Ceccantini, por tudo que vêem me ensinando desde os tempos do mestrado, por terem apoiado meu projeto e por terem me permitido utilizar o laboratório para seccionar as plantas.

Aos professores do Laboratório de Sistemática Vegetal, José Rubens Pirani e Renato de Mello-Silva, pelos conselhos e oportunidades que me deram e pelo convívio sempre agradável.

Aos professores Renato de Mello-Silva, Gladys Flávia de Melo Pinna e Magdalena Rossi pelas ótimas sugestões no exame de qualificação.

Á Marie Anne Van Sluys, por ter me recebido e acolhido no GATE, de maneira tão carinhosa, me possibilitando dar os primeiros passos na biolobia molecular.

Á todos os amigos do laboratório da Dra. Neelima: Helena Garcês, Brad Townsley, Daniel Koenig, Jose Antonio Martinez, Jimmy Moses Tindanmanyire, Lauren Jones, Seisuke Kimura, Julie Kang, Ravi Kumar, Amos Emitati Alakonya, Daniel Chitwood, Yasunori Ichihashi, Aashish Rajan, Meilan Li, Andrea Yanez, Ciera Martinez, Rebekah Clarke, Duy Dang e Thinh Thiem, por toda a ajuda no dia-a-dia do laboratório, pelo excelente ambiente de trabalho, por todas as risadas e ótimos momentos que passamos juntos. Em especial à Helena Garcês e Daniel Koenig, que me ensinaram a fazer hibridizações in situ; ao Brad Townsley, por toda ajuda que me prestou enquanto eu tentava desenvolver um protocolo de VIGS pra Bignonieae e na preparação do manuscrito referente ao

primeiro capítulo da tese; a Ciera Martinez que me ensinou a técnica de microaplicação de auxina e ao Daniel Chitwood, pelas excelentes explicações sobre polaridade foliar.

Á Daniela Kajihara, por ter me ensinado com toda paciência e carinho, os procedimentos mais básicos em biologia molecular durante meu treinamento no GATE.

Á Alexandre Zuntini e Alberto Vicentini pela ajuda durante as coletas na Reserva da Companhia vale do Rio Doce, em Linhares-ES.

Ao Norberto Palacios, secretário do Departamento de Botânica, por ter sido sempre tão gentil e amigo, atendendo minhas solicitações de documentação (e não foram poucas!!) sempre prontamente.

Aos colegas e amigos do Laboratório de Sistemática: Benoît Francis Patrice Loeuille, Juliana Hanna Leite El Ottra, Maurício Watanabe, Cíntia Luiza da Silva Luz, Mariana Wagner 
Loeuille, Rebeca Viana, Maria Fernanda Calió, Juliana Lovo, Juliana Rando, Jenifer Lopes, Livia Echternacht Andrade, Herbert Serafim de Freitas, Euder Glendes Martins, Abel Cangussu Leandro Assis, Matheus (Bozo) Santos e Pedro Fiaschi, pelo ambiente de trabalho sempre agradável e divertido e pelo apoio durante a fase de término da tese. Em especial à Rebeca Viana, nossa excelente representante discente, pela ajuda durante as reuniões da $\mathrm{CCP}$ !

Aos integrantes do Grupo de Estudos em Evolução e Biologia Comparada - GEEBiC grupo coordenado pela Lúcia Lohmann. A composição do grupo vai mudando ao longo do tempo, então gostaria de agradecer especialmente aos meus comtemporâneos: Suzana Alcantara, Alice Calvente, Marcelo Rodrigo Pace, Flavio Gomes-Silva, Carolina Mittelstaedt, Fabiana Firetti, Richard Charles Winkworth, Hugo Cota-Sanchez, Alexandre Rizzo Zuntini, Anselmo Nogueira, Vânia Pretti, Miriam Kaehler, Luiz Henrique Fonseca, Dayane Tarabay e Melina Sakiyama. Obrigada por toda ajuda de vocês durante as prévias de qualificação e defesa, e por tudo que aprendi durante nossas discussões nas reuniões de sexta. Nesse grupo encontrei um ambiente heterogêneo em conhecimento que só encontrei lá, e que contribuiu muito para o meu crescimento e amadurecimento como Botânica. Além disso lá encontrei pessoas admiráveis e fiz amigos que levarei pra vida toda.

Ao meu marido Eduardo Baena, pelo apoio incondicional durante todo o tempo em que desenvolvi este trabalho...apoio espiritual, emocional, logístico, psicológico.....por ter tido tanta paciência comigo durante meus "stresses" de fim de tese. Especialmente, por me dar perspectiva e me trazer a realidade (das maneiras mais inusitadas e engraçadas!) nos momentos em que eu achava que se não colocasse "aquele" parágrafo na tese tudo estaria perdido...Por ter cuidado de mim com tanto amor quando tive problemas de saúde em Davis, por ter se aventurado nessa jornada comigo tornando-a possível.

Á minha mãe, Eliane Silveira, meu irmão Lucas Silveira Domingues, minha avó Wanda Silveira, meu avô Ivo Silveira e ao meu padrasto João Domingues, pelo amor e apoio incondicionais.... por entenderem e muitas vezes perdoarem a minha ausência, por torcerem pelo meu sucesso sempre e por vibrarem de alegria comigo nos dias em que a vida me dá um SIM! Por me darem um lar harmonioso e pacífico pra onde sempre posso voltar e recarregar minhas energias...AMO VOCÊS DE TODO MEU CORAÇÃO!

Ao meu sogro, Luiz Baena, por ter nos acolhido em sua casa, me dando meu segundo lar harmonioso e pacífico onde pude terminar minha tese com tranquilidade!

Á minha tia Leoni Siqueira, minha prima Lucia Siqueira e meu tio Paulo Assunção por todo apoio e pela ajuda financeira que me deram quando eu estava morando em Davis. A ajuda de vocês foi crucial para que essa tese pudesse ser concluída e por isso eu serei eternamente grata.

A minha flozinha, Gisele Rodrigues Costa, técnica do Laboratório de Anatomia Vegetal, por tudo...por ser essa profissional incrível, essa amiga maravilhosa, essa pessoa iluminada....por ter sempre torcido por mim de maneira tão sincera, por toda a ajuda no laboratório e durante as coletas na matinha 
do IB. Senti muita falta das nossas conversas e risadas (ou melhor gargalhadas!!) no tempo que passei em Davis.

Ao Marcelo Rodrigo Pace, pelo companheirismo e amizade. Por estar ao meu lado desde os tempos do mestrado, passando pelos cursos de pós-graduação do Marcelo Dornelas em Campinas e nossas viagens malucas e divertidas pra lá de manhã bem cedinho, pelas discussões botânicas, filosóficas e todas as outras....enfim por ser esse amigo pra todas as horas, por ser essa pessoa tão generosa, pesrpicaz, inteligente e com um senso de humor tão maravilhoso que alegra todos que estão em volta.

Á Suzana Alcantara por todo incentivo, amizade e carinho, por todas as conversas “científicas”, com as quais sempre aprendo muito, e por todas as outras conversas, que sempre acabam em ótimas risadas. Pelos e-mails e conversas no Skype no tempo que eu estava em Davis, que me fizeram sentir tão melhor por tantas vezes, e pelo dia ótimo dia que passamos juntas, chiquérrimas, em São Francisco. Também por todo apoio na fase final da tese, sendo meu "cérebro acessório" e me dando conselhos valiosos.

Ao Flavio Gomes-Silva, por todas as nossas conversas divertidíssimas. A companhia do Flavio principalmente nos dois primeiros anos do meu doutorado fez com que minha rotina ficasse muito mais leve e agradável.

Ás meus amigos das "antigas" e outros não tão "das antigas" assim do laboratório de anatomia vegetal: Vera Alves Lima, Deusa Abreu, Luciana Witovisk, Ana Maria Yoshitake, Viviane Jono, Marina Millanelo, Marina Cattai, André Lima, Tassia Santos, Gustavo Burin, Giuliano Locosseli, Cristiane Gonçalves e Paula Elbl. Infelizmente alguns desses amigos eu não vejo tão frequentemente quanto eu gostaria, mas eles me acompanharam em boa parte da minha caminhada na Botânica, fazem parte da minha história e contribuíram de maneiras variadas para o meu crecimento profissional e pessoal ao longo dos anos. 


\section{RESUMO}

As folhas das angiospermas sofreram grandes modificações funcionais e estruturais ao longo do tempo, e atualmente apresentam uma ampla diversidade de formas, tamanhos e arranjos. Por exemplo, na tribo Bignonieae (Bignoniaceae), as folhas são geralmente 2-3-folíoladas, e o folíolo terminal é frequentemente modificado em gavinha. As gavinhas dos representantes de Bignonieae apresentam formas variadas (simples, bífidas, trífidas ou multífidas) e estão possivelmente envolvidas na diversificação da tribo. Apesar da importância das gavinhas para as plantas escandentes, pouco ainda é conhecido sobre esses órgãos nas angiospermas. Atualmente, existem dados disponíveis sobre genes que controlam o desenvolvimento de gavinhas foliares apenas para Pisum sativum (ervilha). Embora a maioria das angiospermas tenha o desenvolvimento de suas folhas controlado pelos genes $K N O X 1$, em $P$. sativum, KNOX1 não é expresso nos primórdios foliares e seu desenvolvimento é regulado por $L E A F Y /$ FLORICAULA (LFY/FLO). Esses dados sugerem que folhas com gavinhas em outras espécies de planta também podem ser reguladas exclusivamente por $L F Y / F L O$. O presente estudo investigou a evolução e o desenvolvimento dos diferentes tipos de gavinhas em Bignonieae e visou entender como mudanças na morfogênese foliar geraram os padrões atuais de variação morfológica das mesmas. Analisou-se o padrão de expressão dos genes SHOOTMERISTEMLESS (STM, gene KNOX1), PHANTASTICA (PHAN) e $L F Y / F L O$ durante o desenvolvimento foliar de três espécies de Bignonieae com diferentes tipos de gavinhas (simples, trífidas e multífidas), buscando um melhor entendimento da estrutura geral, origem e base genética do desenvolvimento das gavinhas foliares neste grupo. Nossos resultados demonstraram que as folhas se desenvolvem de maneira acrópeta em Bignonieae, bem como indicaram que gavinhas trífidas são ancestrais na tribo, com a evolução dos outros tipos de gavinhas tendo envolvido mudanças heterocrônicas no padrão de desenvolvimento básico das folhas. Além disso, transcritos do gene STM foram detectados em folhas em desenvolvimento, revelando que as folhas em Bignonieae se desenvolvem de maneira diferente das folhas de $P$. sativum, embora ambas apresentem gavinhas. Analises anatômicas revelaram que as gavinhas apresentam simetria bilateral e possuem algumas características similares aos folíolos, corroborando indicações previas de que as gavinhas de Bignonieae representariam folíolos modificados. Estas conclusões foram reforçadas pelo padrão de expressão encontrado para o gene PHAN (gene de identidade adaxial), cujos transcritos estavam confinados ao domínio adaxial do primórdio de gavinha em espécies que possuem gavinhas ramificadas, num padrão muito similar ao padrão observado nos primórdios dos folíolos. Em B. callistegioides, espécie que possui gavinhas simples, PHAN é expresso uniformemente por toda a gavinha, indicando que o domínio adaxial não foi corretamente estabelecido. Assim, as diferenças encontradas nos padrões de expressão do gene $P H A N$ entre espécies com diferentes tipos de gavinhas em Bignonieae indica a existência de uma possível correlação entre a expressão do $P H A N$ com a ramificação de gavinhas. Além disso, o padrão de expressão encontrado sugere que $P H A N$ pode ter um papel importante no estabelecimento da polaridade em gavinhas e no surgimento dos vários tipos de gavinha encontrados na tribo. Além disso, o padrão de expressão do $L F Y / F L O$ em primórdios foliares nos levou a inferir que $L F Y / F L O$ pode ter um papel importante na separação de novos órgãos a partir de zonas meristemáticas. 


\begin{abstract}
Angiosperm leaves have undergone major functional and structural modifications over time, and currently exist in a wide diversity of forms, sizes, and arrangements. For example, in the tribe Bignonieae (Bignoniaceae), leaves are generally 2-3-foliolated, and the terminal leaflet is often modified into tendrils. These tendrils present varied morphologies (simple, bifid, trifid or multifid) and are thought to have been involved in the diversification of Bignonieae. Despite the importance of tendrils for climbing plants, little is still known about the biology of tendrils in the angiosperms. To date, no data is available on the genes that control tendrilled-leaf development in species other than pea (Pisum sativum). Even though $K N O X 1$ genes control leaf development in the majority of compound-leaved angiosperms, in pea, $K N O X 1$ is completely excluded from the leaf primordium and its development is regulated by $L E A F Y / F L O R I C A U L A$ (LFY/FLO). This observation suggests that the development of other tendrilled-leaves might also be exclusively regulated by $L F Y / F L O$ as well. This study investigated the evolution and development of tendril types in Bignonieae in order to further understand how changes in leaf morphogenesis led to current patterns of variation in tendril morphology. We further analyzed the expression patterns of SHOOTMERISTEMLESS (STM, KNOX1 gene), PHANTASTICA (PHAN) and $L F Y / F L O$ during leaf development in three representatives of Bignonieae with different tendril types in order to better understand the structure, origin and genetic basis of leaf tendrils in this plant clade. Our results demonstrate that leaves in Bignonieae develop acropetally, as well as indicates that trifid tendrils are ancestral in the tribe, with the evolution of other tendril types involving heterochonic shifts in the leaf basic developmental pathway. Furthermore, transcripts of STM were detected in developing leaves, revealing that tendrilled leaves of Bignonieae develop differently from those of pea. The anatomical analysis revealed that tendrils are bilaterally symmetrical and present some characteristics that are similar to leaflets, further corroborating earlier suggestions that tendrils indeed represent modified leaflets. This observation was further reinforced by the expression pattern of $P H A N$ (an adaxial identity gene), as $P H A N$ transcripts were confined to the adaxial domain of the tendril primordia in branched-tendrilled species, in a pattern very similar to that observed in leaflet primordia. In B. callistegioides, a simple-tendrilled species, $P H A N$ was expressed throughout the entire tendril, indicating a certain degree of disruption in the establishment of the adaxial domain. The differences encountered in the expression pattern of $P H A N$ amongst species with different tendril types indicate a possible correlation of the expression of $P H A N$ with tendril branching. Furthermore, it suggests an important role for PHAN in the establishment of tendril polarity and in the rise of the various tendril types encountered in Bignonieae. In addition, the pattern of expression of $L F Y / F L O$ in developing leaves has led us to infer that $L F Y / F L O$ may present an important role for the separation of new organs from meristematic zones.
\end{abstract}




\section{ÍNDICE}

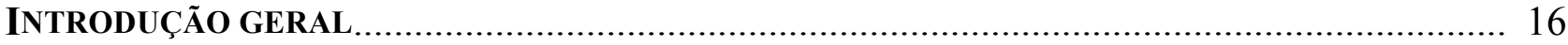

Regulação gênica do desenvolvimento de folhas............................................................ 17

Gavinhas: origens, desenvolvimento e regulação gênica.................................................. 20

A família Bignoniaceae e a tribo Bignonieae............................................................. 27

Referências bibliográficas........................................................................................ 31

Capítulo 1. EVOlution AND DEVElopment OF TENDRILS IN Bignonieae

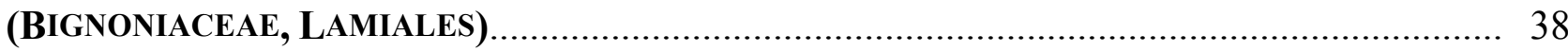

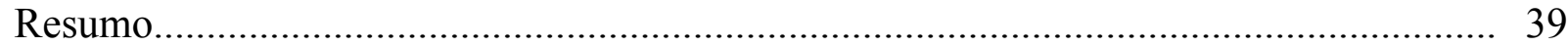

Manuscrito referente ao Capítulo 1............................................................................ 41

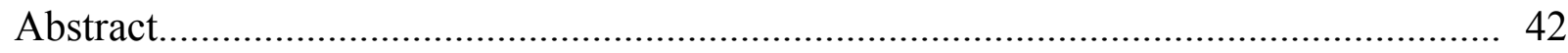

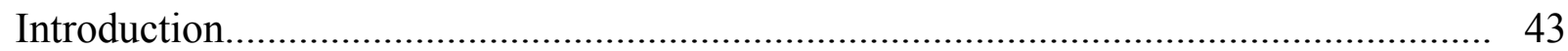

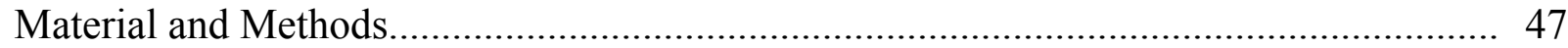

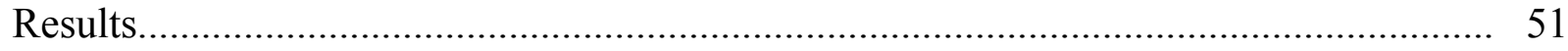

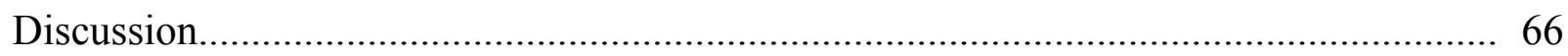

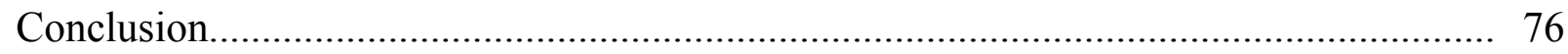

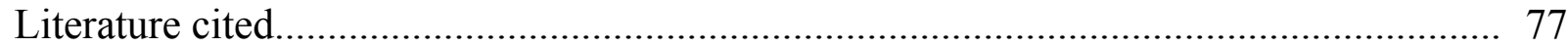

CAPÍtulo 2. NOT ALL TENDRILled LEAVES ARE REGULATED EXCLUSIVELY BY LEAFY/FLORICAULA: EXPRESSION PATTERNS OF STM, LFY/FLO AND PHAN IN BIGNONIEAE (BIGNONIACEAE, LAMIALES),................................................................ 85

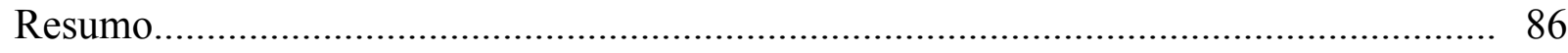

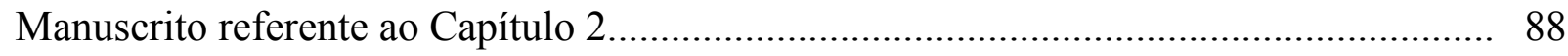

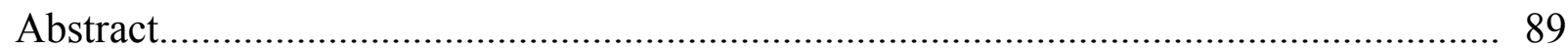

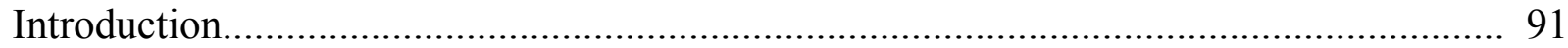

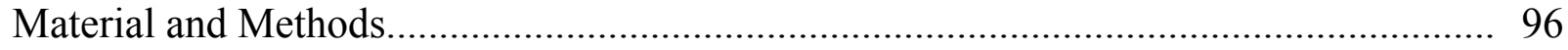

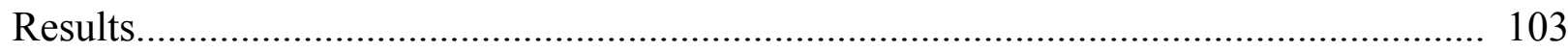

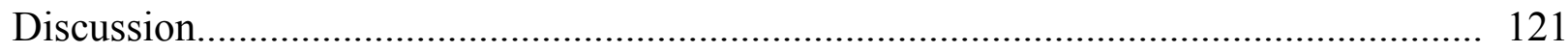

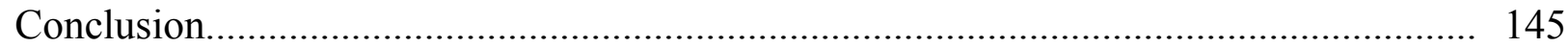

Literature cited............................................................................................... 147

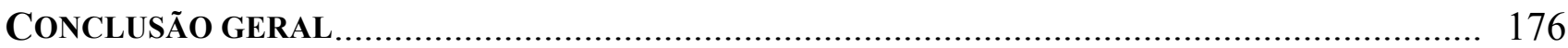




\section{INTRODUÇão GERAL}

This process I discovered by having accidentally left a piece of wool near a tendril. I then bound a guantity of Alax, moss, and wool (the wool must not be dyed, for these tendrils are excessively sensitive to some poisons) loosely round sticks, and placed them near tendrils. The hooked points soon caught the fibres, even loosely floating fibres, and now there was no recoiling; on the contrary, the excitement from the fibres caused the hooks to penetrate the fibrous matter and to curl inwards, so that each hook firmly caught one or two fibres, or a small bundle of them.

Charles Darwin, 1865, on Bignonia capreolata coiling.

"On the movements and habits of climbing plants"

Journal of the Linnean Society of London 9: 1-118. 


\section{INTROduÇão GERAL}

O estabelecimento de correspondências entre os processos de desenvolvimento permite uma visão mais acurada da identidade dos vários órgãos. Ao invés de simplesmente indicar uma certa identidade morfológica em uma estrutura madura, estudos de ontogênese e de genética molecular podem revelar quando e como estas identidades foram formadas (Gleissberg 2003). A genética molecular do desenvolvimento tem descoberto genes regulatórios com profunda influência sobre a morfologia das plantas, com mutantes destes genes sendo conhecidos há décadas. Por um longo tempo duvidava-se que estes genes desempenhassem um papel importante na evolução de estructuras morfológicas no entanto, seu papel na macroevolução já está bem estabelecido (Bachmann \& Gailing 2003). De fato, a maioria destes genes causa sérias deformações e reduzem severamente o "fitness" das plantas mutantes.

Um número considerável de biólogos têm discutido o papel dos "processos de desenvolvimento" na determinação de padrões evolutivos e na determinação da biodiversidade de aspectos fenotípicos. O tema principal desta discussão não é original. No entanto, a existência de novas técnicas em biologia molecular têm permitido com que se possa alcançar resultados que não eram sequer imaginados quando tais questões surgiram (Vergara-Silva, 2003). A “evolução do desenvolvimento", ou "Evo-Devo", visa o entendimento de como a diversidade morfológica surgiu através de mudanças nos programas genéticos de desenvolvimento (Love, 2003). A sua questão central é entender se homólogos morfológicos possuem ou não um mesmo "repertório genético molecular” como base para seu desenvolvimento.

A evolução das interações regulatórias entre genes pode ser a base de muitas novidades evolutivas. No entanto, ainda não sabemos como exatamente isso acontece (Tautz 2002). Os mecanismos de desenvolvimento são bastante complexos, visto que a mesma estrutura pode ser formada por repertórios moleculares diferentes em clados diferentes, ou que um mesmo gene pode atuar na formação de estruturas diferentes (Endress 2003). Porém, a biologia molecular já dispõe de técnicas que são refinadas o suficiente para que estes mecanismos possam ser melhor entendidos possibilitando assim, estudos comparativos e reconstruções filogenéticas detalhadas e confiáveis dos processos de desenvolvimento (Sarkar \& Robert 2003). 
Como a evolução do desenvolvimento é uma área comparativa do conhecimento, deve-se considerar a idéia de homologia em detalhe durante os estudos nesta área (Cracraft 2006). O conceito de homologia surgiu dentro da sistemática comparativa paleontológica e morfológica e permaneceu nesta área de estudo durante os últimos 150 anos (Cracraft 2006). Em sua forma mais básica, homologia significa equivalência de formas e é normalmente interpretada com base na similaridade de posições ou correspondência explicada por ancestralidade comum (Williams \& Humphries 2003). Segundo Pinna (1991), homologia deve ser analisada num contexto evolutivo e é equivalente à sinapomorfia. Cada proposta de homologia envolve dois estágios que estão associados com a criação de hipóteses e legitimação das mesmas. A criação das hipóteses de homologia baseadas em similaridade é denominada homologia primária, a qual pode ou não ser legitimizada posteriormente através de uma análise cladística (Pinna 1991).

O surgimento da evolução do desenvolvimento (Love \& Raff 2003; Gilbert 2003), levou a uma reavaliação de vários conceitos clássicos dentro da biologia, como heterocronia, homeose, heterotopia, novidade evolutiva e homoplasia, além de homologia (Muller \& Wagner 1991; Li \& Johnston 2000; Cronk 2002; Baum \& Donoghue 2002; Hall 2003; Rutishauser \& Moline 2005; Wagner et al. 2005). Em particular, novos dados demonstrando padrões de desenvolvimento semelhantes em organismos pouco relacionados tornaram evidente a necessidade de uma readequação dos conceitos clássicos mencionados acima (Laubichler \& Maienschein 2003; Hall 2003; Cracraft 2005; Brigandt \& Griffiths 2007; Jaramillo \& Kramer 2007; Wagner 2007). Essa readequação, levou a uma re-circunscrição de alguns desses conceitos e acabou por facilitar a análise de dados ontogenéticos a luz das filogenias, permitindo assim um melhor entendimento da evolução do desenvolvimento dos organismos (Raff 2000).

\section{Regulação gênica do desenvolvimento foliar}

A arquitetura primária das plantas é derivada do meristema apical caulinar (MAC), o qual produz folhas, internos, e gemas axilares. Diferenças aparentemente simples na iniciação dos órgãos a partir do meristema podem resultar em morfologias dramaticamente divergentes (Reiser et al. 2000). Ao longo da evolução, uma variedade de folhas com formas, tamanhos e arranjos variáveis surgiram através de 
modificações no padrão de atividade do MAC e também no padrão de desenvolvimento das próprias folhas (Champagne \& Sinha 2004). Imagina-se que a planta ancestral de todas as angiospermas tenha tido folhas simples, e acredita-se que folhas compostas tenham surgido numerosas vezes a partir deste grupo, com diversas reversões para o estado simples. Este padrão sugere que a conversão de folhas simples para folhas compostas e vice-versa pode acontecer com relativa facilidade (Kessler \& Sinha 2004). Progressos científicos recentes têm sido feitos no entendimento dos mecanismos moleculares que regulam o desenvolvimento da folha em algumas espécies-modelo (Champagne \& Sinha 2004). Nestes estudos, estabeleceu-se que dois tipos de fatores de transcrição envolvidos no controle do desenvolvimento de folha, os genes KNOTTED-like da classe 1 (KNOX da classe 1), e o gene LEAFY/ FLORICAULA (LFY/FLO; Hofer et al. 1997).

Os genes KNOX1 têm um papel importante na manutenção da indeterminação do MAC (Hay \& Tsiantis 2010). Análises moleculares indicam que os genes KNOX1 apresentam padrões de expressão diferentes em folhas simples e compostas, o que pode resultar de uma regulação diferencial da expressão dos genes $K N O X$ da classe 1 no MAC (Sinha 1997). Estudos de imunolocalização (Bharathan et al. 2002) revelaram que proteínas estão presentes em folhas em desenvolvimento de várias linhagens de eudicotiledôneas. Entretanto, estas proteínas estão presentes apenas em espécies com folhas compostas.

Uma exceção importante da tendência de expressão do gene $K N O X 1$ no primórdio de folhas compostas é observada em ervilhas, onde o homólogo do KNOX1 não é visto nos primórdios ou em folhas mais velhas (Sinha 1999). Em Pisum, o grau de dissectação da folha é controlado pelo PEAFLO, um homólogo do LEAFY de Arabidopsis (Reiser et al. 2000, Hofer et al. 1997). O gene PEAFLO se expressa em primórdios foliares jovens, e se torna restrito à regiões mais distais no primórdio mais velho. Deleções ou mutações no gene PEAFLO causam a mutação unifoliolata (Sinha 1999, Hofer \& Ellis 1998). A perda de função do PEAFLO impede a aquisição de uma fase transitória de indeterminação nas folhas de ervilha, impedindo a iniciação do folíolo (Hofer et al. 2001). Nestes mutantes ocorre a conversão da gavinha terminal em folíolo, a redução do número de pares de pinas formados, com os distais sendo eliminados primeiro, e a redução de folhas compostas para simples (DeMason 2005). 
Em Eschscholzia californica, eudicotiledônea basal, o desenvolvimento foliar é também regulado pelo gene FLORICAULA/LEAFY (EcFLO), além do gene KNOX1 (EcKNOX1). Especula-se que o controle redundante da dissectação da folha por diversos genes $K N O X$ da classe 1 e pelo gene $E c F L O$ possa ter permitido uma subfuncionalização de aspectos específicos do controle da dissectação das folhas (Groot et al. 2005). Assim, é possível que a presença de duas vias redundantes para a atividade da blastozona foliar, as vias $K N O X 1$ e $L F Y / F L O$, seja a condição ancestral nas eudicotiledôneas.

Outro gene regulador da morfogênese das folhas é o PHANTASTICA. Mutações neste gene causam perda da polaridade abaxial-adaxial em folhas e órgãos florais, gerando folhas filiformes, com características abaxiais em toda a circunferências que são morfologicamente semelhantes à gavinhas ou espinhos (Waites \& Hudson 1995). Pesquisas com plantas que possuem folhas simples sugerem que a justaposição de células destinadas à superfície adaxial da epiderme com células da superfície abaxial seja necessária para o desenvolvimento correto da lâmina foliar (Kim et al. 2003a, 2003b).

Em plantas com folhas simples, o gene PHAN expressa-se no primórdio foliar incipiente e em folhas em desenvolvimento, em um padrão que é mutuamente exclusivo ao padrão de expressão dos genes $K N O X 1$. Já em tomate, ambos $(K N O X$ e $P H A N)$ expressam-se concomitantemente no primórdio foliar, apresentando domínios de expressão temporal e espacialmente coincidentes, com funções que podem ser dependentes entre si. A aquisição de uma regulação positiva entre os genes $K N O X$ e $P H A N$ no primórdio foliar pode ter sido uma mudança evolutiva significativa no primórdio foliar das folhas simples da espécie ancestral para introduzir a formação de folíolos (Kim et al. 2003b).

Os estudos da morfogênese foliar estão progredindo rapidamente no campo da genética molecular e análise funcional. Investigações simultâneas de organismos-modelo como milho, Arabidopsis, Antirrhinum, ervilha e tomate podem permitir não só a montagem do "quebra-cabeças" de como as folhas são feitas, mas também a descoberta das relações de equivalência entre diferentes partes das folhas (Sinha 1999). O atual desafio é explorar se os mecanismos regulatórios, que controlam o desenvolvimento da folha em espécies-modelo, são conservados em outras espécies, e como estes mecanismos evoluíram e produzir as diversas formas atualmente existentes de folhas (Champagne \& Sinha 2004). 


\section{Gavinhas: origens, desenvolvimento e regulação gênica}

Ao se falar em gavinhas, as primeiras imagens que veem a cabeça são as gavinhas de abóbora (Cucurbitaceae) ou videira (Vitaceae), provavelmente devido ao nosso contato frequente com essas plantas por causa do seu antigo e extensivo uso na alimentação dos seres humanos (Maynard and Maynard 2000; Newman 2000). Contudo, gavinhas surgiram em várias famílias de angiospermas, representando um lindo exemplo de evolução convergente (Gerrath et al. 2008). Gavinhas são estruturas definidas por sua função, independentemente da sua origem ontogenética, representando órgãos vegetativos especializados para escalar, que prendem a planta num suporte, enrolando-se nele. Dentre as angiospermas, estas estruturas podem ser derivadas de folhas, ramos, inflorescências, folíolos ou estípulas (Tabela 1; Fig. 1; Putz \& Holbrook 1991).

A família Cucurbitaceae compreende muitas gêneros compostos basicamente por plantas de hábito lianescente, incluindo diversas espécies com gavinhas (Schaefer \& Renner 2011). Nesta família as gavinhas se desenvolvem na região axilar das folhas (Fig. 1H), e várias origens ontogenéticas já foram atribuídas a elas incluindo flores modificadas (Darwin 1875), caules modificados (Sensarma 1955), e órgãos de origem mista, derivados de folhas e caules (Sensarma 1955). Estudos sobre a anatomia nodal e a vascularização sugerem que as gavinhas de Cucurbitaceae podem ser divididas em duas categorias principais (Sensarma 1955): (1) Gavinhas nos quais o suplemento vascular é inteiramente derivado do sistema vascular da gema axilar, e (2) Gavinhas nas quais o suplemento vascular é derivado do traço vascular da gema axilar e do traço vascular da folha. No primeiro tipo de gavinhas, a organização do seu sistema vascular indica que estas gavinhas não podem ser consideradas folhas modificadas. Este tipo de gavinha apresenta um anel fechado de esclerênquima, típico dos caules de Cucurbitaceae, não representando pecíolos modificados ou a nervura principal de uma folha que não sofreu expansão da lamina. Além disso, por causa de características do seu suplemento vascular, estas gavinhas também não podem ser consideradas uma gema axilar com atividade modificada, sendo classificada como uma ramificação do eixo da gema axilar. Gavinhas com esse tipo de vascularização ocorrem em Cucumis e Cucurbita, dentre outros gêneros (Fig. 1H; veja tabela 1). No segundo caso de gavinhas, o suplemento 
vascular é derivado do traço vascular da gema axilar e do traço vascular da folha. Neste caso as gavinhas foram classificadas como tendo origem mista e sendo derivadas parcialmente de estipulas e parcialmente do caule. Esse tipo de gavinha foi detectado em Lupha e Thladiantha (tabela 1).

As classificações descritas acima foram criadas a partir do estudo das estruturas já maduras, porém uma análise recente do desenvolvimento das gavinhas de Echinocystis lobata através de microscopia de epi-iluminaçao revelou que as gavinhas desta espécie representam ramos axilares modificados, com as ramificações das gavinhas representando um ramo de segunda ordem (Gerrath et al. 2008). Nesta espécie, as gavinhas são originadas a partir de um complexo de gemas axilar, que apresenta um aspecto uniforme e inteiro ate o terceiro nó caulinar. No quarto nó, o complexo de gemas sofre uma divisão assimétrica que gera o primórdio de gavinha na região distal do complexo de gemas, enquanto a porção restante continua sendo um complexo de gemas. Uma segunda subdivisão ocorre no quinto nó caulinar, gerando o primórdio floral na região proximal, com o primórdio de gema lateral sendo proveniente da porção mais distal. As gavinha descritas para Echinocystis lobata (Gerrath et al. 2008) provavelmente correspondem às gavinha descritas como "ramificação do eixo da gema axilar" (Sensarma, 1955). No entanto, estudos com Echinocystis lobata não levaram em conta a anatomia nodal e a vascularização das gavinhas, de forma que dados sobre a vascularização são ainda necessários para uma completa elucidação da origem das gavinhas nesta espécie. Desta maneira, ainda não sabemos ao certo qual é a origem ontogenética das gavinhas de Cucurbitaceae.

Em Vitaceae, por outro lado, a origem das gavinhas é um pouco melhor compreendida. As gavinhas são opostas às folhas e podem ser simples, bífidas, trífidas ou ainda apresentarem um maior numero de ramificações, chegando a atingir 12 ramos (Fig. 1I; Wen 2007). Estas gavinhas são derivadas de um primórdio indefinido (do inglês, "uncommitted primordium"), que dá origem exclusivamente a gavinhas em plantas jovens mas, origina inflorescências em plantas maduras (Tucker \& Hoefert 1968; Wen 2007). Um fato que tem intrigado pesquisadores nessa área é que as o primórdio indefinido nunca aparece associado à folhas (Tucker \& Hoefert 1968; Shah \& Dave, 1970). Estudos ontogenéticos em Vitis vinifera mostraram que este primórdio é na realidade uma estrutura muito similar ao meristema apical caulinar, 
mas difere pelo crescimento indeterminado (versus crescimento determinado no MAC). Esta estrutura apresenta uma ou duas camadas de túnica, e produz rudimentos de folha durante seu desenvolvimento. Os primórdios indefinidos são produzidos nos flancos do meristema apical caulinar, sendo anatomicamente indistinguíveis dos primóridos foliares nos estágios iniciais do desenvolvimento. É apenas em estágios posteriores, que estes primórdios se diferenciam, quando o meristema da gavinha adquire as camadas típicas do meristema apical caulinar (Tucker \& Hoefert 1968). As ramificações das gavinhas em Vitis se originam da região axilar das folhas rudimentares, como gemas laterais na região axilar de folhas produzidas pelo meristema apical caulinar. Desta maneira, estudos anatômicos e ontogenéticos levaram a conclusão de que em várias espécies pertencentes a diferente gêneros de Vitaceae as gavinhas são um ramo extra-axilar modificado (Tucker \& Hoefert 1968; Shah \& Dave 1970; Tabela 1).

Embora evidências anatômicas indiquem que gavinhas são ramos vegetativos modificados, estudos moleculares utilizando um mutante L1 de Vitis, concluíram que as gavinhas são na realidade inflorescências modificadas (Boss \& Thomas 2003). Este mutante de Vitis é derivado da regeneração de células da camada L1 do meristema apical caulinar e desenvolve plantas anãs que produzem inflorescências ao longo do ramos, onde normalmente seriam produzidas gavinhas. A produção de gavinhas no lugar de inflorescências foi atribuída a uma incapacidade do mutante de apresentar uma resposta normal a giberelina (GA). A resposta alterada deste mutante a GA se deve a uma mutação no gene Vvgail, ortólogo do GAI de Arabidopsis, e plantas mutantes pra este gene se tornam insensíveis a GA. Assim, enquanto em Arabidopsis GAs promovem a floração em Arabidopsis (Blasquez et al. 1998), em Vitis, as plantas selvagens que apresentam uma resposta normal a GA desenvolvem gavinhas, e plantas mutantes insensíveis a GA desenvolvem inflorescências. Assim, em Vitis as GAs teria uma função oposta a função que desempenham em Arabidopsis, e as gavinhas seriam inflorescências modificadas impedidas de completar seu desenvolvimento por ação das GAs (Boss \& Thomas 2003).

Estudos da expressão dos genes ligados ao desenvolvimento floral em Vitis também indicaram que gavinhas são inflorescências modificadas (Calonje et al. 2004). Os genes FRUITFULL (FUL) e APETALA1 (AP1), em conjunto com outros genes, dentre eles o $L F Y$, controlam a identidade do 
Tabela 1. Alguns exemplos de espécies de angiosperma com gavinhas de diferentes origens.

\begin{tabular}{|c|c|c|c|c|}
\hline Ordem & Família & Gênero & Origem & Fonte \\
\hline \multirow[t]{6}{*}{ Ranunculales } & Papaveraceae & Dicentra & folíolo terminal modificado & Kadereit, 1993 \\
\hline & & Disocapnos & folíolo terminal modificado & Kadereit, 1993 \\
\hline & & Trigonocapnos & folíolo terminal modificado & Kadereit, 1993 \\
\hline & & Ceratocapnos & folíolo terminal modificado & Kadereit, 1993 \\
\hline & Ranunculaceae & Clematis & pecíolo volúvel e/ou raque volúvel & Tamura, 1993; Bell\&Brian, 2008 \\
\hline & & Naravelia & folíolo terminal modificado & Tamura, 1993 \\
\hline Ericales & Polemoniaceae & Cobaea & folíolo terminal modificado & Wilken, 2004 \\
\hline \multirow[t]{4}{*}{ Asterales } & Asteraceae & Mutisia & folíolo terminal modificado & Hind, 2007 \\
\hline & & Austrosynotis & pecíolo volúvel & Hind, 2007 \\
\hline & & Mikaniopsis & pecíolo volúvel & Hind, 2007 \\
\hline & & Cissampelopsis & pecíolo volúvel & Hind, 2007 \\
\hline \multirow[t]{3}{*}{ Fabaceae } & Fabaceae & Pisum & folíolo terminal modificado/prolongamentos da raque & Darwin, 1875; Tattersall et al., 2004 \\
\hline & & Vicia & folíolo terminal modificado/prolongamentos da raque & Darwin, 1875; Tattersall et al., 2004 \\
\hline & & Lathyrus & folíolo terminal modificado/prolongamentos da raque & Darwin, 1875; Tattersall et al., 2004 \\
\hline \multirow[t]{10}{*}{ Cucurbitales } & Cucurbitaceae & Cucurbita & ramificação do eixo da gema axilar/caule modificado & Sensarma, 1955; Schaefer\&Renner, 2011 \\
\hline & & Cucumis & ramificação do eixo da gema axilar/caule modificado & Sensarma, 1955; Schaefer\&Renner, 2011 \\
\hline & & Citrullus & ramificação do eixo da gema axilar/caule modificado & Sensarma, 1955; Schaefer\&Renner, 2011 \\
\hline & & Cocccinia & ramificação do eixo da gema axilar/caule modificado & Sensarma, 1955; Schaefer\&Renner, 2011 \\
\hline & & Lagenaria & ramificação do eixo da gema axilar/caule modificado & Sensarma, 1955; Schaefer\&Renner, 2011 \\
\hline & & Momordica & ramificação do eixo da gema axilar/caule modificado & Sensarma, 1955; Schaefer\&Renner, 2011 \\
\hline & & Mukia & ramificação do eixo da gema axilar/caule modificado & Sensarma, 1955; Schaefer\&Renner, 2011 \\
\hline & & Thladiantha & originada de um complexo caule-estípula & Sensarma, 1955 \\
\hline & & Lupha & originada de um complexo caule-estípula & Sensarma, 1955 \\
\hline & & Echinocyctis & ramo lateral modificado & Gerrath et al., 2008 \\
\hline \multirow[t]{5}{*}{ Vitales } & Vitaceae & Vitis & inflorescência ou caule modificado/ramo extra-axilar modificado & Wen, 2007; Boss\&Thomas, 2003;Tucker\&Hoefert, 1968; Shah\&Dave, 1970 \\
\hline & & Parthenocissus & inflorescência ou caule modificado/ramo extra-axilar modificado & Wen, 2007; Shah\&Dave, 1970 \\
\hline & & Tetrastigma & ramo extra-axilar modificado & Shah\&Dave, 1970 \\
\hline & & Ampelopsis & ramo extra-axilar modificado & Shah\&Dave, 1970 \\
\hline & & Cissus & inflorescência ou caule modificado & Wen, 2007 \\
\hline \multirow[t]{3}{*}{ Malpighiales } & Passifloraceae & Passiflora & pedicelo da flor central/derivada de um complexo de gemas & Feuillet\&MacDougal, 2007; Shah\&Dave, 1971a; Cultri, 2009 \\
\hline & & Adenia & pedicelo da flor central/gema caulinar & Feuillet\&MacDougal, 2007 \\
\hline & Lophopyxidaceae & Lophopyxis & Gavinha foliar & Stevens, 2001 (onwards); Takhtajan, 1997 \\
\hline \multirow[t]{2}{*}{ Rosales } & Rhamanceae & Gouania & derivada do pedúnculo da inflorescência & Medan\&Schirarend, 2004 \\
\hline & & Helinus & derivada do pedúnculo da inflorescência & Medan\&Schirarend, 2004 \\
\hline \multirow[t]{3}{*}{ Caryophyllales } & Polygonaceae & Brunnichia & porção terminal do pedúnculo da inflorescência & Brandbyge, 1993, \\
\hline & & Antigonon & porção terminal do pedúnculo da inflorescência & Brandbyge, 1993, Shah\&Dave, 1971b \\
\hline & Dioncophyllaceae & Triphyophyllum & bifurcação da nervura central nas pontas das folhas & Takhtajan, 1997 \\
\hline \multirow[t]{4}{*}{ Sapindales } & Sapindaceae & Lophostigma & associadas à inflorescência, par na base da raque & Acevedo-Rodriguez, 1993; Acevedo-Rodriguez et al., 2011 \\
\hline & & Serjania & gema caulinar & Acevedo-Rodriguez et al. 2011 \\
\hline & & Cardiospermum & associadas à inflorescência, par na base da raque & Acevedo-Rodriguez et al. 2011 \\
\hline & & Paullinia & associadas à inflorescência, par na base da raque & Acevedo-Rodriguez et al. 2011 \\
\hline \multirow[t]{4}{*}{ Liliales } & Smilacaceae & Smilax & duplicação do pecíolo/de origem estipular & Arber, 1920; Bell\&Brian, 2008 \\
\hline & Colchicaceae & Gloriosa & ponta da folha & Nordenstam, 1998 \\
\hline & & Littonia & ponta da folha & Nordenstam, 1998 \\
\hline & Petermanniaceae & Petermannia & inflorescência terminal transformada em gavinhas ramificadas & Takhtajan, 1997; Stevens, 2001 (onwards) \\
\hline Poales & Flagellariaceae & Flagellaria & extensao da nervura foliar central espessada & Takhtajan, 1997; Appel\&Bayer, 1998 \\
\hline
\end{tabular}


meristema floral (Weigel et al. 1992). FUL começa a se expressar no período de transição do meristema apical caulinar para meristema floral, sendo reprimido antes do início da formação dos meristemas florais propriamente ditos, enquanto $L F Y$ e $A P 1$ são expressos nos meristemas florais (Weigel et al. 1992). Em Vitis, transcritos de FUL e APl foram detectados em gavinhas, durante todo seu desenvolvimento e inclusive nas suas ramificações. Transcritos destes genes não foram detectados em nenhum outro órgão vegetativo, como folhas, raízes ou meristema apical caulinar em fase vegetativa. Desta maneira, a expressão de genes de identidade floral em gavinhas levou os autores a concluírem que em Vitis as gavinhas são órgãos reprodutivos modificados (Calonje et al. 2004). Além disso, estudos mostram que o gene $L F Y$ também é expresso em gavinhas de videira em desenvolvimento (Carmona et al. 2002)

Passifloraceae é uma outra família dentre as angiospermas em que muitos membros apresentam gavinhas (Feuillet \& MacDougal 2007). Em várias espécies de Passiflora, as gavinhas estão posicionadas nas axilas das folhas, juntamente com flores e ramos vegetativos, ou podem estar diretamente associadas às inflorescências, possivelmente representando o pedicelo da flor central modificado (Fig. 1J; Feuillet \& MacDougal 2007). Assim como acontece em Vitis e Echinocystis, em Passiflora as gavinhas se desenvolvem a partir de um complexo de gemas (Shah \& Dave 1971a). A diferenciação deste complexo de gemas em primórdios de gavinha e gemas florais ocorre em geral no segundo nó caulinar. Além disso, ainda na região axilar da folha, uma terceira gema acessória se desenvolve. Porém, esta gema acessória se desenvolve entre o primórdio de gavinha e o eixo caulinar, independente do complexo de gemas, somente após o complexo de gemas ter se diferenciado em gemas de gavinha e flores (Shah \& Dave 1971a). O desenvolvimento dos primórdios de gavinha e florais a partir de uma gema inicialmente comum também foi demonstrado em Passiflora suberosa e Passiflora edulis (Cultri 2009). Nestas duas espécies o gene $L F Y$ se expressa no complexo de gemas, tanto na parte que originará flores quanto na região que originará gavinhas. Em estágios mais avançados de desenvolvimento a expressão de $L F Y$ foi confinada as pontas das gavinhas (Cultri 2009). Desta maneira as gavinhas de Vitaceae e Passifloraceae compartilham muitas características em comum quanto ao seu desenvolvimento. Assim, é possível que como acontece em videira (Carmona et al. 2002; Calonje et al. 2004), outros genes ligados ao desenvolvimento floral, além do $L F Y$ (Cultri 2009), se expressem durante o desenvolvimento de gavinhas em Passiflora. 


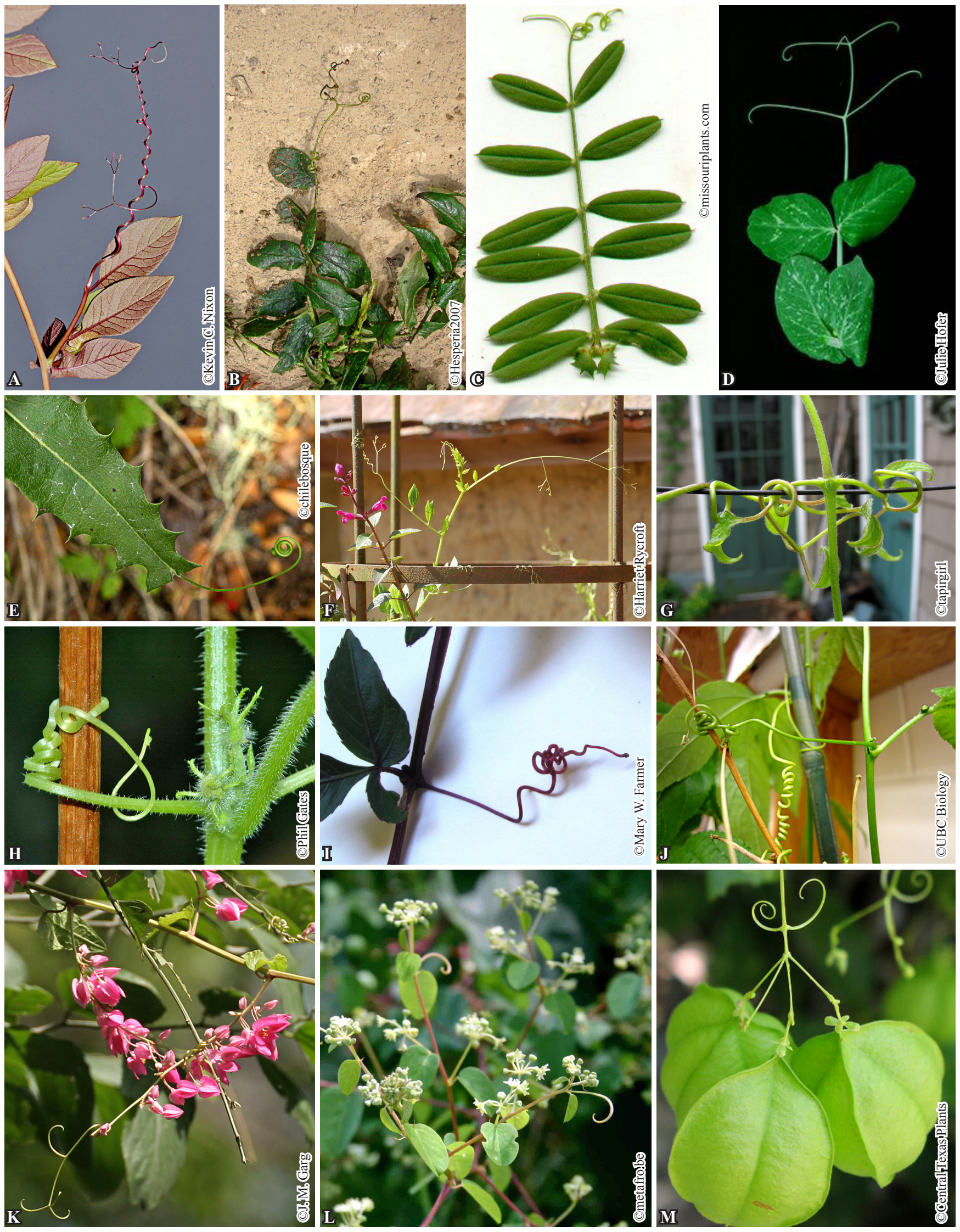


Algumas outras famílias de plantas apresentam gavinhas claramente associadas à inflorescências, porem estas foram muito menos estudadas e não existem dados sobre o desenvolvimento de gavinhas nessas plantas. É o caso de espécies da família Sapindaceae, em particular espécies dos gêneros Lophostigma, Cardiospermum e Paullinia, que apresentam um par de gavinhas na base da raque da inflorescência (Fig. 1M; Acevedo-Rodriguez 1993, Acevedo-Rodriguez et al. 2011). Gavinhas associadas ao pedúnculo da inflorescência são encontradas em gêneros da família Polygonaceae (Fig. 1K; Shah \& Dave 1971b) e da família Rhamnaceae (Fig. 1L; Medan \& Schirarend 2004). Dentre as monocotiledôneas, gavinhas derivadas de inflorescências modificadas são encontradas em Petermanniaceae (Tabela 1; Takhtajan 1997).

A principal função das folhas é a realização da fotossíntese, porem em varias famílias de plantas, folíolos inteiros ou partes da folha são modificados em gavinhas. Gavinhas que são aparentemente derivadas de folíolos ocorrem em Asteraceae (Fig. 1B; Hind 2007), Polemoniaceae (Fig. 1A; Wilken 2004), Papaveraceae (Kadereit 1993) e Ranunculaceae (Tamura 1993), além de em Bignoniaceae e Fabaceae (Fig. 1C-D; Darwin 1875).

A espécie com gavinhas foliares mais extensivamente estudada até o momento foi Pisum sativum (ervilha, Fabaceae). A exata origem das gavinhas nesta espécie ainda é incerta, podendo estas serem derivadas de folíolos ou representar prolongamentos da raque foliar (Tattersal et al. 2004). Os estudos moleculares com folhas de ervilha vêm elucidando como as gavinhas se desenvolvem, e quais genes regulam sua formação. Porem, o desenvolvimento das folhas em ervilha é regulado pelo gene $L F Y$, e

Figura 1: Exemplos de orgãos de angiospermas utilizados para escalar. A-D. Gavinhas foliares derivadas do folíolo terminal modificado. A. Cobaea scandens, gavinhas multífidas. B. Mutisia sp., gavinhas multífidas. C. Vicia sp., gavinhas simples. D. Pisum sativum, gavinhas simples. E. Mutisia araucana, ponta da folha modificada em gavinha. F. Cobaea sp., folíolo terminal modificado em gavinha. G. Clematis sp., folha com pecíolo e raque volúveis. H. Cucumis sp., gavinhas derivadas da gema axilar. I. Cissus sp., inflorescência modificada em gavinha. J. Passiflora sp., gavinha derivada de um complexo de gemas. K-M. Gavinhas associadas à inflorescências. K. Antigonon leptopus, gavinha originada na porção terminal do pedúnculo da inflorescência. L. Helinus mystacinus, gavinha derivada do pedúnculo da inflorescência. M. Cardiospermum halicacabum, par de gavinhas na base da inflorescência, provavelmente derivadas do pedúnculo. 
não pelos genes KNOX1, o que é considerado uma exceção dentre as angiospermas (Hofer et al. 1997). Assim, estudos com folhas portadoras de gavinhas em outras espécies poderiam levar a um melhor entendimento da biologia destas estruturas.

Gavinhas derivadas de outras partes da folha que não os folíolos são encontradas em Dioncophyllaceae (Takhtajan 1997). Em Triphyophyllum (Dioncophyllaceae), pares de gavinhas são formados pela bifurcação da nervura central nas pontas das folhas. Gavinhas similares a estas também são encontradas em algumas espécies de Mutisia (Fig.1E; Asteraceae). Dentre as monocotiledôneas, gavinhas de origem foliar são encontradas em membros da família Smilacaceae, Colchicaceae (Fig. 1L) e Flagellariaceae (tabela 1). Em Gloriosa, Littonia e espécies de Flagellariaceae, a gavinha se desenvolve na ponta das folhas (Arber 1920; Takhtajan 1997; Nordenstam 1998). Em particular, as gavinhas em Flagellariaceae se tornam bastante enroladas em fibrosas após encontrar um suporte. Em Smilax são observadas duas gavinhas associadas ao pecíolo da folha, as quais são consideradas derivadas de estípulas modificadas (Arber 1920). Além disso, muitas famílias de plantas que não possuem gavinhas propriamente ditas desenvolveram pecíolos volúveis. Este é o caso de várias espécies de Clematis (Ranunculaceae) e também de Perianthomega vellozoi, espécie da tribo Bignonieae. Algumas espécies de Clematis apresentam raque e pecíolo volúveis (Fig. 1G; Bell \& Brian 2008).

As varias famílias que desenvolveram gavinhas foliares são distantemente relacionadas e estudos comparando a regulação genica dessas estruturas nas diversas famílias poderiam trazer resultados muito interessantes, e elucidar, por exemplo, se os mesmos genes participam da formação de gavinhas foliolares e das gavinhas que se desenvolvem nas pontas das folhas de monocotiledôneas. Estudos como este poderiam trazer um maior entendimento de como as convergências evolutivas são geradas e consequentemente de como mudanças na regulação genica geram a diversidade fenotípica.

\section{A família Bignoniaceae e a tribo Bignonieae}

As Bignoniaceae são essencialmente Pantropicais, com poucos representantes em zonas temperadas; a América tropical é o centro de diversidade da família (Lohmann 2004). O restante das 
Bignoniaceae tropicais occorre em Madagascar, África, e Ásia tropical. A família é abundante em diversos habitats tropicais, ocorrendo predominantemente em florestas úmidas (Lohmann 2004). A família foi tradicionalmente dividida em 8 tribos (Gentry 1991), mas uma filogenia recente publicada para a família levou a mudanças consideráveis na classificaçao das tribos (Olmstead et al. 2009). Atualmente, 8 linhagens são reconhecidas: Jacarandeae, Tourrettieae, Tecomeae, o "Palaeotropical clade”, Oroxyleae, Catalpeae, "Tabebuia alliance" e Bignonieae (Olmstead et al. 2009).

Apesar de novas linhagens terem sido estabelecidas atualmente em Bignoniaceae, a tribo Bignonieae é fortemente sustentada como uma linhagem monofilética e sua circunscrição tem se mantido constante (Spangler \& Olmstead 1999, Olmstead et al. 2002, Olmstead et al. 2009). A tribo como um todo inclui 22 gêneros e 383 espécies (Lohmann \& Ulloa 2006 onwards; Lohmann 2011) e constitui a maior tribo dentro das Bignoniaceae. A tribo inclui todas as Bignoniaceae lianescentes neotropicais com cápsulas septicidas, além de Bignonia capreolata L., que ocorre no sudoeste dos Estados Unidos. Bignonieae é caracterizada pela presença de um padrão distinto de desenvolvimento do floema, pelo hábito lianescente, e pela presença de gavinhas (Lohmann 2006). O grupo está amplamente distribuído pelos neotrópicos ocorrendo na América Central, Amazônia, Mata Atlântica, em áreas secas abertas, e nas savanas da Argentina, Bolivia, Brasil, e Paraguai (Lohmann 2006).

Lohmann (2006) utilizou sequências de DNA nuclear e do cloroplasto para reconstruir a filogenia da tribo Bignonieae. A análise combinada dos dados resultou em árvores similares aquelas geradas a partir da análise individual, mas forneceu uma maior sustentação para o parentesco sugerido entre as espécies. Foram reconstruídos 21 grupos de espécies bem sustentados, cada um dos quais foi corroborado por sinapormorfias morfólogicas. Estes grupos representam a base para uma revisão formal da tribo ao nível genérico (Lohmann 2011). A filogenia de Bignonieae, em conjunto com os dados morfológicos que já existem para a tribo, tornam este grupo um excelente modelo para o estudo da evolução de caracteres morfológicos, ecologia evolutiva, e biogeografia neotropical.

Trabalhos anatômicos com Bignoniaceae são escassos e trazem em geral análises superficiais de poucas espécies (Panizza 1967, Hyakutake \& Grotta 1965, Scareli-Santos \& Varanda 2003, Ogundipe 
\& Wujek 2004). A maioria dos trabalhos anatômicos são sobre anatomia do caule, uma característica notável das lianas (Dobbins 1971; Outer \& Veenendaal 1983; Carlquist 1985; Dobbins \& Fisher 1986; Santos \& Miller 1990; Gasson \& Dobbins 1991; Gabrielli 1993; Santos \& Miller 1997, Pace et al. 2009, 2011). Em lianas, o câmbio frequentemente apresenta uma atividade diferencial que leva a formação de um câmbio variante, o qual inclui quatro porções equidistantes que reduzem a taxa de produção de floema e aumentam a produção de xilema, resultando no desenvolvimento de 4, ou múltiplos de 4, cunhas de floema que interrompem o xilema secundário e possivelmente aumentam a flexibilidade do caule (Schenck 1893; Solereder 1908; Dobbins 1971; Pace et al. 2009).

Em particular, as folhas de Bignonieae apresentam grande variação morfológica. Estas são sempre opostas, variando de 2-3 foliolada com o folíolo terminal modificado em gavinha, a biternadas ou biternada-pinadas com a divisão terminal modificada em gavinha. Folhas compostas-palmadas ou simples são também encontradas no grupo, porém em menor frequência. Algumas espécies podem ainda produzir folhas simples e compostas no mesmo indivíduo, como é o caso de Fridericia samydoides (Cham.) L.G. Lohmann (Lohmann 2003, 2004). Gavinhas foliares são também encontradas em espécies da tribo Tourrettieae, uma pequena tribo da família Bignoniaeae que compreende apenas 4 espécies, cuja distribuição é restrita aos Andes (Gentry 1980; D’Arcy 1997; Olmstead et al. 2009). Espécies lianescentes de Bignoniaceae distribuídas nas regiões Paleotropicais não possuem gavinhas, fenômeno que pode estar relacionado com as taxas de especiação mais baixas das Bignoniaceae nessa região (Gentry 1991). Por outro lado, a aquisição de gavinhas nas espécies de Bignoniaceae neotropicais pode ter levado a incrível diversificação das espécies lianescentes de Bignoniaceae nesta região (Gentry 1991).

Em Bignonieae, as gavinhas são sempre folíolos modificados, cuja região terminal pode ser dividida de maneiras diferentes, podendo ser simples, trífidas, ou multífidas (várias vezes trifurcada). Uma única espécie, Tanaecium pyramidatum (Rich.) L.G. Lohmann, apresenta gavinhas bífidas (Lohmann 2003). Em algumas espécies de Bignonieae as gavinhas estão ausentes na maioria dos indivíduos e um folíolo terminal se desenvolve ao invés da gavinha, dando origem à uma folha trifoliolada. Este padrão sugere que os genes (ou gene) responsáveis pela mudança entre a produção de folíolos e gavinhas devem 
estar inativos nestas espécies (Lohmann 2003). Os diferentes tipos de gavinhas evoluíram múltiplas vezes em Bignonieae (Lohmann 2003). Apesar dos diferentes tipos de gavinhas terem evoluído diversas vezes, eles são bastante constantes dentro de clados, representando sinapomorfias úteis para a caracterização de gêneros (Lohmann 2003, 2011.).

A tribo Bignonieae é um grupo extremamente interessante para estudos da evolução do desenvolvimento pois já conta com uma filogenia molecular robusta (Lohmann 2006). Além disso, a tribo exibe considerável variação morfológica em caracteres vegetativos e reprodutivos. Dentre os caracteres que apresentam um padrão de evolução bastante interessante são as gavinhas, as quais apresentam morfologias bastante variáveis. Além disso, a aquisição de gavinhas pode ter sido uma inovação-chave (Gentry 1991), possibilitando uma grande diversificação de Bignonieae. No entanto pouco ainda se conhece sobre a anatomia e o desenvolvimento destas estruturas até o momento.

O objetivo deste estudo foi investigar os padrões de evolução e desenvolvimento das gavinhas foliares em Bignonieae. Além disso, este trabalho teve também por objetivo começar a desvendar os genes que regulam o desenvolvimento de gavinhas em Bignonieae, mais especificamente, determinar se os genes SHOOTMERISTEMLESS e LEAFY/FLORICAULA eram expressos durante o desenvolvimento dos diferentes tipos de gavinhas, e se o gene PHANTASTICA poderia estar relacionado com o surgimento de gavinhas em Bignonieae.

Esta tese está dividida em dois capítulos. No primeiro capitulo tratamos do desenvolvimento e evolução das gavinhas em Bignonieae. Neste capítulo apresentamos os padrões evolutivos obtidos através das reconstruções de caracteres ancestrais do tipo de gavinha através de vários métodos de reconstrução. Apresentamos também os dados obtidos com a análise do desenvolvimento de 11 espécies de Bignonieae, com diferentes tipos de gavinhas, através de microscopia eletrônica de varredura. Por fim, interpretamos os dados ontogenéticos à luz dos padrões de reconstrução de caracteres ancestrais com o intuito de entender como mudanças no padrão de desenvolvimento das folhas resultaram na diversidade de tipos de gavinhas encontradas atualmente na tribo Bignonieae.

No segundo capítulo focamos na regulação gênica do desenvolvimento e na identificação da 
origem de gavinhas em Bignonieae. Mais especificamente, apresentamos dados de hibridização in situ dos genes SHOOTMERISTEMLESS, PHANTASTICA e LEAFY/FLORICAULA durante o desenvolvimento de folhas de três espécies de Bignonieae portando diferentes tipos de gavinha. Além disso, também apresentamos os resultados de nossas investigações anatômicas sobre a polaridade das partes foliares. Na discussão, relacionamos os padrões de expressão gênica com o desenvolvimento, e também com as diferenças encontradas na polaridade, dos diferentes tipos de gavinhas. Discutimos também possíveis papéis dos genes STM, PHAN e LFY/FLO na formação das gavinhas em Bignonieae.

\section{REFERÊNCIAS BIBLIOGRÁFICAS}

ACEVEDO-RODRÍGUEZ, P. 1993. A revision of Lophostigma (Sapindaceae). Systematic Botany 18: 379-388.

ACEVEDO-RODRÍGUEZ, P., P.C VAN WELZEN, F. ADEMA, e R.W.J.M. VAN DER HAM. 2011. Sapindaceae. Pp. 357-407. In: Kubitzki, K. (ed.), The Families and Genera of Flowering Plants. X. Springer-Verlag, Berlin, Germany.

APPEL, O., e C. BAYER. 1998. Flagellariaceae. Pp. 208-211. In: Kubitzki, K. (ed.), The Families and Genera of Vascular Plants. IV. Springer-Verlag, Berlin, Germany.

ARBER, A. .1920. Tendrils of Smilax. Botanical Gazette 69: 438-442.

BACHMANN, K., e O. GAILING. 2003. The genetic dissection of the stepwise evolution of morphological characters. Pp. 35-62 in T.F. Stuessy, V. Mayer and E. Hörandl (eds.), Deep Morphology - Toward a Renaissance of Morphology in Plant Systematics. A.R.G. Gantner Verlag, Ruggell, Liechtenstein.

BAUM, D.A. e M.J. DONOGHUE. 2002. Transference of function, heterotopy, and the evolution of plant development. Pp. 52-69 in Q. Cronk, R. Bateman \& J. Hawkins (eds.), Developmental Genetics and Plant Evolution. Taylor and Francis, London.

BELL, A.D., e A. BRYAN. 2008. Plant Form: An Illustrated Guide to Flowering Plant Morphology, "New Edition". Timber Press, Portland, Oregon. 432pp.

BHARATHAN, G., T.E. GOLIBER, C. MOORE, S. KESSLER, T. PHAM, e N.R. SINHA. 2002. Homologies in leaf form inferred from KNOXI gene expression during development. Science 296: 1858-1860.

BLAZQUEZ, M.A., R. GREEN, O. NILSSON, M.R. SUSSMAN e D. WEIGEL. 1998. Gibberellins promote flowering of Arabidopsis by activating the LEAFY promoter. Plant Cell 10: 791-800.

BOSS, P.K. e M.R. THOMAS. 2002. Association of dwarfism and floral induction with a grape 'green revolution' mutation. Nature 416: 847-850. 
BRANDBYGE, J. 1993. Polygonaceae. Pp. 532-543. In Kubitzki, K., Rohwer, J. G., \& Bittrich, V. (eds), The Families and Genera of Vascular Plants. II. Springer-Verlag, Berlin, Germany.

BRIGANDT, I. e P.E. GRIFFITHS. 2007. The importance of homology for biology and philosophy. Biology and Philosophy 22: 633-641.

BUSCH, A. e S. GLEISSBERG. 2003. EcFLO, a FLORICAULA-like gene from Eschscholzia californica is expressed during organogenesis at the vegetative shoot apex. Planta 217: 841-848.

CALONJE, M., CUBAS, P., MARTÍNEZ-ZAPATER, J.M., E CARMONA, M.J. 2004. Floral meristem identity genes are expressed during tendril development in grapevine. Plant Physiology 135, 1-11.

CARLQUIST, S. 1985. Observations on functional wood histology of vines and lianas: vessel dimorphism, tracheids, vasicentric tracheids, narrow vessels, and parenchyma. Aliso 11:139-157.

CARMONA, M.J., P. CUBAS, e J.M. MATÍNEZ-ZAPATER. 2002. VFL, the grapevine FLORICAULA/LEAFY ortholog, is expressed in meristematic regions independently of their fate. Plant Physiology 130: 68-77.

CHAMPAGNE, C. e N.R. SINHA. 2004. Compound leaves: equal to the sum of their parts? Development 131: 4401-4412.

CRACRAFT, J. 2005. Phylogeny and evo-devo: Characters, homology, and the historical analysis of the evolution of development. Zoology 108: 345-356.

CRONK, Q.C.B. 2002. Perspectives and paradigms in plant evo-devo. Pp. 1-14 in Q. C. B. Cronk, R. M. Bateman \& J. A. Hawkins (eds.), Developmental Genetics and Plant Evolution. Taylor \& Francis, London.

CULTRI, L. 2009. Estudos da função do gene LEAFY (LFY) em duas espécies de Passiflora. Dissertação de mestrado. Universidade Estadual de Campinas, Insituto de Biologia. Campinas, São Paulo. 57 pp.

D'ARCY, W.G. 1997. A review of the genus Eccremocarpus (Bignoniaceae). Annals of the Missouri Botanical Garden 84: 103-111.

DARWIN, C. 1875. The movements and habits of climbing plants. 2d ed. John Murray, London. 118pp.

DEMASON, D.A. 2005. Auxin-cytokinin and auxin-gibberellin interactions during morphogenesis of the compound leaves of pea (Pisum sativum). Planta 222: 151-166.

DOBBINS, D.R. 1971. Studies on the anomalous cambial activity in Doxantha unguis-cati (Bignoniaceae). II. A case of differential production of secondary tissues. American Journal of Botany 58:697-705.

DOBBINS, D.R., e J.B. FISHER. 1986. Wound responses in girdled stems of lianas. Botanical Gazette 147:278289.

ENDRESS, P.K. 2003. What should a "complete" morphological phylogenetic analisys entail? Pp. 131-164, in T.F. Stuessy, V. Mayer and E. Hörandl (eds.), Deep Morphology - Toward a Renaissance of Morphology in Plant Systematics. A.R.G. Gantner Verlag, Ruggell, Liechtenstein.

FEUILLET, C., e J.M. MACDOUGAL. 2006. Passifloraceae. Pp. 270-281, in Kubitzki, K. (ed.), The Families and 
Genera of Vascular Plants. IX. Springer-Verlag, Berlin, Germany.

GABRIELLI, A.C. 1993. Estrutura caulinar secundária em Pyrostegia venusta (Ker.) Miers - Bignoniaceae. Revista Brasileira de Botânica 16:167-173.

GASSON, P. e D.R. DOBBINS. 1991. Wood anatomy of the Bignoniaceae, with a comparison of trees and lianas. IAWA Bulletin n.s. 12:389-417

GENTRY, A.H. 1980. Bignoniaceae. Part I (tribes Crescentieae and Tourrettieae). Flora Neotropica Monographs 25: $1-150$

GENTRY, A.H. 1991. The distribution and evolution of climbing plants. Pp 1-49, in F.E. Putz and H.A. Mooney (eds.), The Biology of Vines. Cambridge University Press, New York.

GERRATH, J.M., T.B. GUTHRIE, T.A. ZITNAK e U. POSLUSZNY. 2008. Development of the axillary bud complex in Echinocystis lobata (Cucurbitaceae): interpreting the cucurbitaceous tendril. American Journal of Botany 95: 773-781.

GILBERT, S.F. 2003. The morphogenesis of evolutionary developmental biology. International Journal of Developmental Biology 47: 467-477.

GLEISSBERG, S. 2003. Comparative morphology in relation to molecular genetics and phylogenetic systematics. Pp. 107-115, in T.F. Stuessy, V. Mayer and E. Hörandl (eds.), Deep Morphology - Toward a Renaissance of Morphology in Plant Systematics. A. R. G. Gantner Verlag, Ruggell, Liechtenstein.

GROOT, E. P., N. SINHA e S. GLEISSBERG. 2005. Expression patterns of STM-like KNOX and Histone H4 genes in shoot development of the dissected-leaved basal eudicot plants Chelidonium majus and Eschscholzia californica (Papaveraceae). Plant Molecular Biology 58: 317-331.

HALL, B.K. 2003. Descendent with modification: the unity underlying homology and homoplasy as seen through an analysis of development and evolution. Biological Reviews of the Cambridge Philosophical Society 78: 409-433.

HAY, A. e M. TSIANTIS. 2010. KNOX genes: versatile regulators of plant development and diversity. Development 137, 3153-3165.

HIND, D.J.N. 2007. Asteraceae. Pp. 90-122, In: K. Kubitzki, J.W. Kadereit, and C. Jeffrey (eds.). The Families and Genera of Vascular Plants. VIII. Springer-Verlag, Heidelberg.

HOFER, J.M.I. e T.H.N. ELLIS. 1998. The genetic control of patterning in pea leaves. Trends in Plant Science 3: 439-444.

HOFER, J.M.I., C.W. GOURLAY, A. MICHAEL e T.H.N. ELLIS. 2001. Expression of a class 1 Knotted1-like homeobox gene is down-regulated in pea compound leaf primordia. Plant Molecular Biology 45: 387-398.

HOFER, J.M.I., L. TURNER, R. HELLENS, M. AMBROSE, P. MATTHEWS, A. MICHAEL e T.H.N. ELLIS. 1997. UNIFOLIOLATA regulates leaf and flower morphogenesis in pea. Current Biology 7: 581-587. 
HYAKUTAKE, S. e A.S. GROTTA. 1965. Contribuição ao estudo morfológico e anatômico de Anemopaegma arvense (Vell.) Stellfeld. var. petiolata Bur. Bignoniaceae. Revista da Faculdade de Farmácia e Bioquímica da Universidade de São Paulo 3: 51-78.

JARAMILLO, M.A. e E.M. KRAMER. 2007. The role of developmental genetics in understanding homology and morphological evolution in plants. International Journal of Plant Sciences 168: 61-72.

KADEREIT, J.W. 1993. Papaveraceae. Pp. 494-505, In: K. Kubitzki, J.G. Rohwer, and V. Bittrich (eds.). The Families and Genera of Vascular Plants. II. Springer-Verlag, Heidelberg.

KELLY, A.J., M.B. BONNLANDER e D.R. MEEKS-WAGNER. 1995. NFL, the tobacco homolog of FLORICAULA and LEAFY is transcriptionally expressed in both vegetative and floral meristems. The Plant Cell 7: 225-234.

KESSLER, S. e N.R. SINHA. 2004. Shaping up: the genetic control of leaf shape. Current Opinion in Plant Biology 7: 65-72.

KIM, M., S. MCCORMICK, M. TIMMERMANS e N.R. SINHA. 2003a. The expression domain of PHANTASTICA determines leaflet placement in compound leaves. Nature 424: 438-443.

KIM, M., T. PHAM, A. HAMIDI, S. MCCORMICK, R. KUZOFF e N.R. SINHA. 2003b. Reduced leaf complexity in tomato wiry mutants suggests a role for PHAN and KNOX genes in generating compound leaves. Development 130: 4405-4415.

LAUBICHLER, M.D. e J. MAIESCHEIN. 2003. Ontogeny, anatomy, and the problem of homology: Carl Gegenbaur and the American tradition of cell lineages. Theory in Biosciences 122: 194-203.

LI, P. e M.O. JOHNSTON. 2000. Heterochrony in plant evolutionary studies through the twentieth century. The Botanical Review 66: 57-88.

LOHMANN, L.G. e C. ULLOA. 2006 onwards. Bignoniaceae in iPlants prototype checklist. Available at http:// www.iplants.org (accessed 02 October 2006 13:32 GMT).

LOHMANN, L.G. 2003. Phylogeny, classification, morphological diversification and biogeography of Bignonieae (Bignoniaceae, Lamiales). Tese de doutorado. University of Missouri-St. Louis, St. Louis, Missouri, USA.

LOHMANN, L.G. 2004. Bignoniaceae. Pp 51-53, in N. Smith, S.A. Mori, A. Henderson, D.W. Stevenson and S.V. Heald (eds.). Flowering Plants of the Neotropics. Princeton University Press and the New York Botanical Garden. Princeton and Oxford.

LOHMANN, L.G. 2006. Untangling the phylogeny of neotropical lianas (Bignonieae, Bignoniaceae). Americam Journal of Botany 93: 304-318.

LOHMANN, L.G. 2011. A new generic classification based on molecular phylogenetic data and morphological synapomorphies. Annals of Missouri Botanical Garden. (In Press)

LOVE, A.C. 2003. Evolutionary morphology, innovation, and the synthesis of evolutionary and developmental biology. Biology and Philosophy 18: 309-345. 
LOVE, A.C. e R.A. RAFF. 2003. Knowing your ancestors: themes in the history of evo-devo. Evolution and Development 5: 327-330.

MAYNARD, D. e D.N. MAYNARD. 2000. Cucumbers, melons, and watermelons. In: Kiple, K.F. e Ornelas, K.C. (eds.), The Cambridge World History of Food. Vol I. Cambridge University Press. Cambridge, New York, Melbourne, Madrid, Cape Town, Singapore, São Paulo, pp. 298-312.

MCHALE, N.A. e R.E. KONING. 2004. PHANTASTICA regulates development of the adaxial mesophyll in Nicotiana leaves. The Plant Cell 16: 1251-1262.

MEDAN, D. e C. SCHIRAREND. 2004. Rhamnaceae. Pp. 320-338. In: Kubitzki, K. (ed.), The Families and Genera of Vascular Plants. VI. Springer-Verlag, Berlin, Germany.

MULLER, G.B. e G.P. WAGNER. 1991. Novelty in evolution - restructuring the concept. Annual Review of Ecology, Evolution, and Systematics 22: 229-256.

MÜLLER, K.J., X. HE, R. FISCHER e D. PRÜFER. 2006. Constitutive Knoxl gene expression in dandelion (Taraxacum officinale, Web.) changes leaf morphology from simple to compound. Planta 224: 1023-1027.

NEWMAN, J.L. 2000. Wine. Pp. 730-740. In: Kiple, K.F. e Ornelas, K.C. (eds.), The Cambridge World History of Food. Vol I. Cambridge University Press. Cambridge, New York, Melbourne, Madrid, Cape Town, Singapore, São Paulo.

NORDENSTAM, B. 1998. Colchicaceae. Pp. 175-185. In: Kubitzki, K. (ed.), The Families and Genera of Vascular Plants. III. Springer-Verlag, Berlin, Germany.

OGUNDIPE, O.T. e D.E. WUJEK. 2004. Foliar anatomy on twelve genera of Bignoniaceae (Lamiales). Acta Botanica Hungarica 46: 337-361

OLMSTEAD, R.G., M. L. ZJHRA, L.G. LOHMANN, S.O. GROSE e A.J. ECKERT. 2009. A molecular phylogeny and classification of Bignoniaceae. American Journal of Botany 96: 1731-1743.

OLMSTEAD, R.G., M.J. ZJHRA, S.O. GROSE, A.J. ECKERT e R.E. SPANGLER. 2002. Molecular phylogeny, evolution and classification of the Bignoniaceae. Abstract of talk presented at the ASPT Botanical meeting: Botany 2002, Maddison, Wisconsin, USA. See: http://www.botany2002.org/section12/abstracts/240.shtml.

OUTER, R.W. e V. VEENENDAAL. 1983. Wood anatomy of Uncarina leandrii H. Humb. (Pedaliaceae) and its relation to Bignoniaceae. IAWA Bulletin n.s. 4:53-59

PACE, M.R., L.G. LOHMANN e V. ANGYALOSSY. 2009. The rise and evolution of the cambial variant in Bignonieae (Bignoniaceae). Evolution and Development 11: 465-479.

PACE, M.R., LOHMANN, L.G., e V. ANGYALOSSY. 2011. Evolution of disparity between the regular and variant phloem in Bignonieae (Bignoniaceae). American Journal of Botany 98: 602-618.

PANIZZA, S. 1967. Contribuição ao estudo morfológico e anatômico da Jacaranda caroba (Velloso) DC., (Bignoniaceae). Revista da Faculdade de Farmácia e Bioquímica da Universidade de São Paulo 5: 93-106. 
PINNA, M.C.C. 1991. Concepts and tests of homology in the cladistic paradigm. Cladistics 7: 367-394.

PUTZ, F.E. e N.M. HOLBROOK. 1991. Biomechanical studies of vines. Pp 73-97, in F.E. Putz, and H.A. Mooney (eds.), The Biology of Vines. Cambridge University Press, New York.

RAFF, R. A. 2000. Evo-devo: the evolution of a new discipline. Nature 1: 74-79.

REISER, L., P. SANCHEZ-BARACALDO e S. HAKE. 2000. Knots in the family tree: evolutionary relationship and function of Knox homeobox genes. Plant Molecular Biology 42: 151-166.

RUTISHAUSER, R. e P. MOLINE. 2005. Evo-devo and the search for homology ("sameness") in biological systems. Theory in Biosciences 124: 213-241.

SANTOS, G. e R.B. MILLER. 1990. Wood anatomy of Tecomeae. Flora Neotropica Monograph 25: 336-358.

SANTOS, G. e R.B. MILLER. 1997. Wood anatomy of Jacaranda (Bignoniaceae): systematic relationships in sections monolobos and dilobos as suggested by twig and stem wood rays. IAWA Journal 18: 369-383.

SARKAR, S. e J.S. ROBERT. 2003. Introduction. Biology and Philosophy 18: 209-217.

SCARELI-SANTOS, C. e E.M. VARANDA. 2003. Morphological and histochemical study of leaf galls of Tabebuia ochracea (Cham.) Standl. (Bignoniaceae). Phytomorphology 53: 207-214.

SCHAEFER, H. e S.S. RENNER. 2011. Cucurbitaceae. Pp. 112-174, In: Kubitzki, K. (ed.), The families and genera of vascular plants. X. Springer-Verlag, Berlin, Germany.

SCHENCK, H. 1893. Beiträge zur Biologie und Anatomie der Lianen im Besonderen der in Brasilien einheimischen Arten. II. Theil. Beiträge zur Anatomie der Lianen in A. F. W. Schimper (ed.), Botanische Mittheilungen aus den Tropen. Gustav Fisher, Jena.

SENSARMA, P. 1955. Tendrils of the Cucurbitaceae: their morphological nature on anatomical evidences. Proceedings of the National Institute of Science in India 21: 162-169.

SHAH, J.J., e DAVE, Y.S. 1970. Morpho-histogenic studies on tendrils of Vitaceae. American Journal of Botany 57: 363-373.

SHAH, J.J., e DAVE, Y.S. 1971a. Morpho-histogenic studies on tendrils of Passiflora. Annals of Botany 35: 627635.

SHAH, J.J., e DAVE, Y.S. 1971b. Ontogeny of tendrils in Antigonon leptopus H. \& Arn. Annals of Botany 35: 411-419.

SINHA, N.R. 1997. Simple and compound leaves: reduction or multiplication? Trends in Plant Science 2: 396401.

SINHA, N.R. 1999. Leaf development in angiosperms. Annual Review of Plant Physiology 50: 419-446.

SOLEREDER, H. 1908. Systematic Anatomy of the Dicotyledons, Vols. I and II. Clarenton Press, Oxford. 
SPANGLER, R. e R.G. OLMSTEAD. 1999. Phylogenetic analysis of Bignoniaceae based on the cpDNA gene sequences $r b c \mathrm{~L}$ and $n d h \mathrm{~F}$. Annals of the Missouri Botanical Garden 86:33-46.

STEVENS, P. F. 2001 onwards. Angiosperm Phylogeny Website. Version 9, June 2008 [and more or less continuously updated since].” will do. http://www.mobot.org/MOBOT/research/APweb/.

TAKHTAJAN, A. 1997. Diversity and Classification of Flowering Plants. Columbia University Press, New York. 620pp.

TAMURA, M. 1993. Ranunculaceae. Pp. 563-583, In: K. Kubitzki, J.G. Rohwer, and V. Bittrich (eds.). The Families and Genera of Vascular Plants. II. Springer-Verlag, Heidelberg.

TATTERSALL, A.D., L. TURNER, M.R. KNOX, M.J. AMBROSE, T.H.N. ELLIS, e J.M.I. HOFER. 2005. The mutant crispa reveals multiple roles for PHANTASTICA in pea compound leaf development. The Plant Cell 17: 1046-1060.

TAUTZ, D. 2002. Evo-devo graduates to new levels. Trends in Genetics 18: 66-67.

TUCKER, S.C. e L.L. HOEFERT. 1968. Ontogeny of tendril in Vitis Vinifera. American Journal of Botany 55: $1110-\&$.

VERGARA-SILVA, F. 2003. Plants and the conceptual articulation of evolutionary developmental biology. Biology and Philosophy 18: 249-284.

WAGNER, G. 2007. The developmental genetics of homology. Nature Reviews Genetics 8: 473-479.

WAGNER, G. P., J. MEZEY e R. CALABRETTA. 2005. Natural selection and the origin of modules. Pp. 33-49 in W. Callebaut \& D. Rasskin-Gutman (eds.), Modularity: Understanding the Development and Evolution of Natural Complex Systems. MIT Press, Cambridge, Massachussets.

WAITES, R. e A. HUDSON. 1995. phantastica: a gene required for dorsoventrality of leaves in Antirrhinum majus. Development 121: 2143-2154.

WEIGEL, D., J. ALVAREZ, D.R. SMYTH, M.F. YANOFSKY e E.M. MEYEROWITZ. 1992. LEAFY controls floral meristem identity in Arabidopsis. Cell 29: 843-859.

WEN, J. 2007. Vitaceae. Pp. 466 - 478, In: K. Kubitzki (ed.), The families and genera of vascular plants. IX. Springer-Verlag, Berlin, Germany.

WILKEN, D.H. 2004. Polemoniaceae. Pp. 300-312, In: K. Kubitzki (ed.). The Families and Genera of Vascular Plants. VI. Springer-Verlag, Heidelberg.

WILLIAMS, D.M. e C.J. HUMPHRIES. 2003. Homology and character evolution. Pp. 119-130, in T.F. Stuessy, V. Mayer and E. Hörandl (eds.), Deep Morphology - Toward a Renaissance of Morphology in Plant Systematics. A.R.G. Gantner Verlag, Ruggell, Liechtenstein. 


\section{Capítulo 1}

\section{Evolution AND DEVelopment of tendRils in Bignonieae (Bignoniaceae, Lamiales)}

The tendril strikes some object, and guickly curls round and firmly grasps it. In the course of some hours it contracts into a spire, dragging up the stem, and forming an excellent spring. All movements now cease. By growth the tissues soon become wonderfully strong and durable. The tendril has done its work, and done it in an admirable manner.

Charles Darwin, 1865

"On the movements and habits of climbing plants"

Journal of the Linnean Society of London 9: 1-118. 


\section{RESUMO}

A tribo Bignonieae engloba todas as Bignoniaceae lianescentes encontradas na região Neotropical. A maioria dos representantes desta tribo apresenta folhas 2-3-folioladas, com o folíolo terminal modificado em gavinha. Em Bignonieae, as gavinhas apresentam formas variadas e podem estar envolvidas na diversificação deste grupo. Entretanto, o conhecimento sobre a biologia e evolução das mesmas ainda é escasso. Neste trabalho, investigamos o padrão de evolução e o desenvolvimento das gavinhas com diferentes morfologias visando entender como mudanças ocorridas durante o desenvolvimento destas estruturas geraram os padrões atuais de variação morfológica encontrados atualmente. Para tal, utilizamos uma filogenia de Bignonieae recentemente publicada como uma base para reconstruir o padrão de evolução dos diferentes tipos de gavinhas. Estas reconstruções foram realizadas sob os princípios da máxima parcimônia (ACCTRAN e DELTRAN) e máxima verossimilhança. Além disso, investigamos a ontogênese em folhas de 11 espécies e 7 gêneros de Bignonieae (i.e., Bignonia, Cuspidaria, Fridericia, Tanaecium, Dolichandra, Mansoa, e Amphilophium) e uma ampla diversidade de tipos de gavinhas (i.e., simples, trífida e multífida). As reconstruções de estados de caráter ancestrais do tipo de gavinha sugerem que gavinhas trífidas são ancestrais na tribo, com os outros tipos de gavinha tendo evoluído através de uma série de mudanças nos padrões de desenvolvimento. Além disso, estudos ontogenéticos trouxeram informações importantes para a resolução das principais ambiguidades encontradas nas reconstruções de estados ancestrais. Especificamente: (1) Ambas espécies de Bignonia analisadas (B. prieurei e $B$. callistegioides; espécies com gavinhas simples) não apresentam qualquer vestígio de ramos laterais que pudessem ser interpretados como remanescentes de um suposto ancestral que possuía gavinhas trífidas, corroborando assim a otimização ACCTRAN a qual hipotetizou "gavinhas simples" como o ancestral desta linhagem; (2) O desenvolvimento das gavinhas de Tanaecium pyramidatum (gavinhas trífidas) inicialmente segue um padrão e taxa de diferenciação que é similar ao padrão de espécies que possuem gavinhas simples (i.e., Fridericia e Cuspidaria), apresentando um atraso no desenvolvimento dos ramos laterais em relação a outras espécies que possuem gavinhas trífidas, e assim corroborando a hipótese de que seu ancestral já apresentava gavinhas simples, como sugerido pelas reconstruções de ML e ACCTRAN. A interpretação dos dados ontogenéticos á luz de uma robusta filogenia de Bignonieae 
gerou hipóteses específicas sobre os processos evolutivos e mudanças na regulação gênica que podem estar associados á diversidade morfológica de gavinhas encontradas atualmente em Bignonieae. Em particular, sugerimos que a evolução das gavinhas envolveu processos heterocrônicos e hipotetizamos que mudanças no padrão de expressão de genes ligados ao desenvolvimento de folhas compostas podem ter gerado a diversidade morfológica das gavinhas encontrada atualmente em Bignonieae.

Palavras-chave: Bignonieae, Bignoniaceae, desenvolvimento, evolução, folhas compostas, gavinhas foliares, heterocronia, lianas, reconstrução de estados ancestrais de caráter. 


\title{
Evolution and development of tendrils in Bignonieae (Bignoniaceae, Lamiales)
}

\author{
Mariane Silveira de Sousa-Baena, ${ }^{1,2^{*}}$ Neelima Roy Sinha, ${ }^{2^{*}}$ and Lúcia G. Lohmann ${ }^{1^{*}}$
}

\section{ACKNOWLEDGements}

We thank Alexandre Zuntini, Marcelo Pace and Gisele Rodrigues Costa for assistance with field collections, Harri Lorenzi for allowing us to obtain specimens from his private collection, and "Companhia Vale do Rio Doce (CVRD)" for allowing us to collect at its natural reserve in Linhares (Espirito Santo). We also thank Brad Townsley, Marcelo Pace and Suzana Alcantara for valuable comments in this manuscript, and Andrew Doust for helpful suggestions in the early stages of the development of this project. This paper is part of the Ph.D. dissertation of M.S., which was supported by fellowships from the Conselho Nacional de Desenvolvimento Científico e Tecnológico (CNPq, Grant 140470/2007-7), and from the Coordenação de Aperfeiçoamento de Pessoal de Nível Superior (CAPES, Grant 4395-08-5), a crossdisciplinary training grant from MORPH (Molecular and Organismic Research in Plant History), and NSF Developmental Mechanisms award 0641696 (to N.S.).

${ }^{1}$ Universidade de São Paulo, Instituto de Biociências, Departamento de Botânica, Rua do Matão, 277, CEP 05508-090, São Paulo, SP, Brazil.

${ }^{2}$ Section of Plant Biology, University of California at Davis, 1 Shields Avenue, Davis, CA 95616, USA.

•E-mails for correspondence: m.sousabaena@yahoo.com; nrsinha@ucdavis.edu; 1lohmann@usp.br. 


\section{Abstract \\ The tribe Bignonieae includes all Neotropical lianescent Bignoniaceae. The leaves of Bignonieae} are generally 2-3-foliolated, with the terminal leaflet modified into a tendril. These tendrils present varied morphologies and are thought to have been involved in the diversification of Bignonieae. Little, however, is still known about the biology and evolution of tendrils. This study investigated the evolution and development of tendril types in Bignonieae in order to further understand how changes in leaf morphogenesis led to current patterns of variation in tendril morphology. We used a recently published phylogeny of Bignonieae as the basis to reconstruct the patterns of evolution of tendril types using maximum likelihood and maximum parsimony assumptions, with both ACCTRAN and DELTRAN optimization schemes implemented in the latter. In addition, we investigated the ontogeny of leaves from 11 different species of Bignonieae representing 7 different genera (i.e., Bignonia, Cuspidaria, Fridericia, Tanaecium, Dolichandra, Mansoa, and Amphilophium) and a wide diversity of tendril types (i.e., simple, trifid, and multifid). Ancestral character state reconstructions of tendril type suggests that trifid tendrils are ancestral in the tribe, with other tendril types evolving through a series of developmental changes. Furthermore, tendril ontogenetic studies provided key information for the resolution of major ambiguities in the ancestral state reconstructions of tendril type. In particular: (1) Both species of Bignonia analyzed (B. prieurei and B. callistegioides; simple tendrilled species) did not present any traces of lateral branches that could be a reminiscent of a trifid tendrilled ancestor, corroborating the ACCTRAN hypothesis of a "simple tendril" condition for the ancestor of that lineage; (2) Tanaecium pyramidatum (trifid tendrils) presented a pattern and rate of tendril differentiation that initially followed the same pattern of taxa with simple tendrils (i.e., Fridericia and Cuspidaria), presenting a developmental delay in relation to other trifid tendrilled species thus, favoring the hypothesis of a simple tendrilled ancestor, as suggested by the ML and ACCTRAN optimizations. The interpretation of the ontogenetic data in the light of a robust phylogenetic framework led to specific hypotheses about the evolutionary processes and respective changes in gene regulation that may have led to the current tendril morphology found in Bignonieae. In particular, we suggest that tendril evolution involved heterochrony, and hypothesize that changes in the expression of genes that are associated with compound leaf development may have led to the diversity of 
tendril morphology currently seen in Bignonieae.

Key words: ancestral character state reconstructions, Bignonieae, Bignoniaceae, compound leaves, foliar tendrils, development, evolution, heterochrony, lianas.

\section{INTRODUCTION}

The plant family Bignoniaceae is essentially pantropical, with few species in temperate zones (Gentry, 1991). The family is abundant in several tropical habitats, centered in tropical America, and especially common in lowland forests (Lohmann, 2004). The Bignoniaceae has been traditionally divided into 8 tribes (Gentry, 1991), but a recent phylogeny of the family has led to considerable changes in the tribal classification of the group (Olmstead et al., 2009). Currently, 8 main lineages are recognized: Jacarandeae, Tourrettieae, Tecomeae, the "Palaeotropical clade", Oroxyleae, Catalpeae, "Tabebuia alliance," and Bignonieae.

The tribe Bignonieae includes 383 species, and represents the largest tribe within the family (Lohmann \& Ulloa, 2006 onwards; Lohmann, 2011). The tribe is well supported as monophyletic (Spangler \& Olmstead, 1999; Lohmann, 2006; Olmstead et al., 2009), and includes 21 strongly supported clades (Lohmann, 2006) that are also supported by morphological synapomorphies and recognized as genera in a recent classification of the group (Lohmann, 2003; Lohmann, 2011). Most representatives of Bignonieae are woody lianas, with the tribe representing the most diverse and abundant clade of lianas in the Neotropics (Gentry, 1991).

Lianas account for a large percentage of the leaf biomass and floristic diversity in tropical forests (Gentry, 1991; Schnitzer et al., 2005), contribute $\sim 44 \%$ of the woody species in some regions of the Amazon Rainforest (Pérez-Salicrup et al., 2001), and are important for the dynamics of forest structure and composition (Isnard \& Silk, 2009; Schnitzer \& Bonger, 2002). The abundance and diversity of lianas rises considerably with forest disturbance (Schnitzer \& Bonger, 2002; Bradshaw et al., 2009), which has led to a recent increase in the interest in liana research (Pace et al., 2009; van der Heijden, et al., 2010; 
Zhu \& Cao, 2010; Alcantara \& Lohmann, 2010).

The lianoid habit and associated structural modifications have intrigued biologists since Darwin (1875). Considerable research has been conducted on the stem anatomy of lianas, which include an unusual pattern of cambium activity (Dobbins, 1971; Dobbins \& Fisher, 1986; Carlquist, 1988; Gasson \& Dobbins, 1991; Gabrielli, 1993; Pace et al., 2009; Pace et al., 2011). In liana species, the cambium often presents a differential activity that leads to the formation of a variant cambium that includes four equidistant portions that decrease the production of xylem while increase the production of phloem, resulting in the development of four to multiples of four phloem wedges that furrow the secondary xylem and presumably increase the flexibility of stems while climbing (Schenck, 1893; Solereder, 1908; Dobbins, 1971; Pace et al., 2009).

Leaf tendrils represent another key feature that is associated with the evolution of the climbing habit (Gentry, 1980; Lohmann, 2006). However, these structures have received much less attention and to date very little is known about their biology, evolution, and development. Tendrils are filiform organs that have the ability to twine around other structures, representing an efficient climbing strategy. These structures are defined by their function, and can present different ontogenetic origins, ranging from the modification of leaves, leaflets, stipules and branches, to inflorescences, or even roots (Putz \& Holbrook, 1991).

In Bignonieae, most tendrils arise by modifications of the terminal leaflets of the 1-3-ternated leaves, except for Perianthomega vellozoi that climbs exclusively with the aid of twinning petioles (Lohmann, 2006; Lohmann, 2011). Tendrils of the representatives of Bignonieae exhibit remarkable morphological diversity, varying from simple to bifid, trifid or multifid, with some species also presenting adhesive discs or hooks at the tip (Lohmann, 2006; Lohmann, 2011; see Fig. 1). Foliar tendrils are also found in representatives of tribe Tourrettieae, a tribe that is restricted to the Andes and includes four species with branched foliar tendrils (Gentry, 1980; D’Arcy, 1997; Olmstead et al., 2009). Tendrils are lacking in the Paleotropical liana Bignoniaceae, a phenomenom that has been thought to be associated with the lower speciation rates of the liana Bignoniaceae in that part of the world (Gentry, 1991). In contrast, the acquisition of tendrils in the Neotropics may represent a key innovation that may have led 
to the incredible diversification of liana Bignoniaceae in that region (Gentry, 1991).

Although simple in structure, tendrils undergo complex modifications during development that result from negative phototropism, circumnutation, thigmotropism, and contact coiling (Darwin, 1875; Monshausen et al., 2008; Jaffe \& Galston, 1968; Jaffe et al., 2002). During coiling, tendrils display an
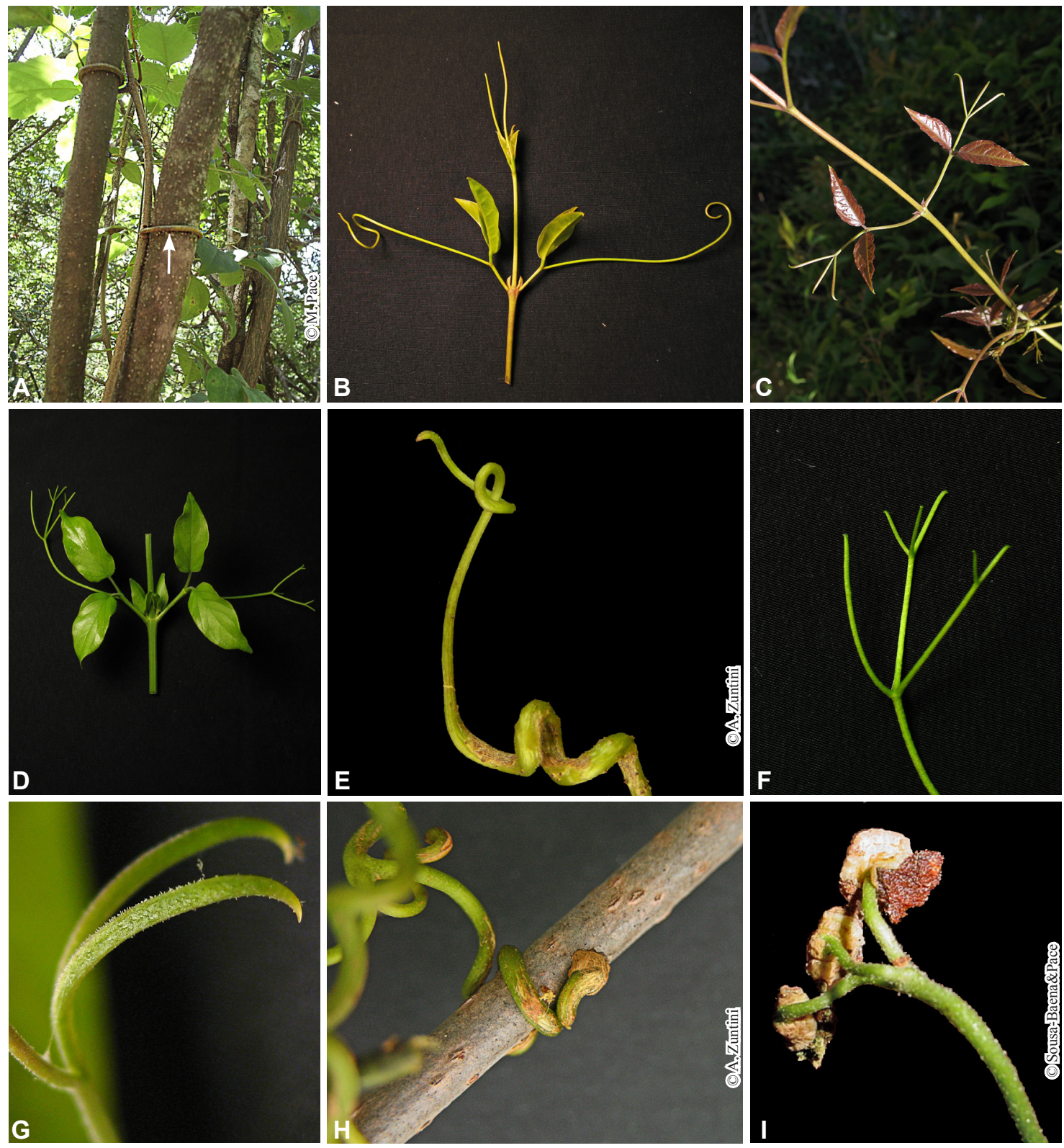

Figure 1. Sample of climbing organs found in Bignonieae. - A. Perianthomega vellozoi, twinning petioles (arrow). - B. Bignonia callistegioides, opposite leaves composed of two leaflets and a terminal simple tendril. - C. Dolichandra unguis-cati, compound leaves with terminal trifid tendril. - D. Amphilophium buccinatorium, terminal multifid tendril. - E. Adenocalymma bracteatum, detail of a simple tendril. - F. Amphilophium buccinatorium, detail of a multifid tendril. - G. Dolichandra unguiscati, detail of a trifid tendril showing the uncinate tips. - H. Amphilophium crucigerum, tendril tip with adhesive disc. - I. Tynanthus cognatus, detail of a trifid tendril tip showing the adhesive discs. 
increase in respiration rate after contacting a support (Riehl \& Jaffe, 1982). Furthermore, modifications in membrane permeability are coupled with an increase in solute efflux (Jaffe \& Galston, 1968; Jaffe, 1975; Liss \& Weiler, 1994; Engelberth, 2003). The appearance of cortical gelatinous fibers is also associated with tendril coiling in several plant species (Meloche et al., 2007; Bowling \& Vaughn, 2009). All of these processes are coordinated by an intricate hormonal regulation (Junker, 1976; DeMason \& Chawla, 2004) and are responsible for tendril development in the angiosperms.

Most developmental studies involving foliar tendrils were conducted on peas (Pisum sativa) and other species that belong to the IRLC Clade ("Inverted Repeat-Lacking Clade") of legumes (Gourlay et al., 2000; Champagne et al., 2007; Hofer et al., 2009). This clade also contains Vicia, Lathyrus and Lens, all of which bear foliar tendrils (Wojciechowski et al., 2004). Pea leaves are compound, comprised of a basal pair of stipules, one or more pairs of opposite leaflets, and a terminal branched tendril. Pea leaf primordia develop acropetally, with the tendril identity of the terminal leaflet primordium only being determined at the fourth plastochron (Gould et al., 1994).

Significant progress has been made towards a better understanding of the molecular mechanisms that regulate pea leaf development. While class 1 KNOTTED1-like (KNOX1) genes appear to control the development of compound leaves across angiosperms (Sinha, 1999; Champagne \& Sinha, 2004), UNIFOLIOLATA, a LEAFY/FLORICAULA ortholog, seems to regulate compound leaf development in peas (Hofer \& Ellis, 1998; Champagne \& Sinha, 2004). Recent studies on the garden pea (Pisum sp.) and on the sweet pea (Lathyrus sp.) indicated that interactions between UNIFOLIOLATA and TENDRILLESS prevent terminal leaflets from developing into a blade, leading to the formation of a terminal tendril instead (Hofer et al., 2009).

Despite the recent advances in molecular genetics of tendrils in model organisms, very little is still known about the anatomy, morphogenesis or evolution of tendrils in non-model organisms. The great diversity in tendril morphology encountered in representatives of Bignonieae, coupled with the availability of a robust phylogeny for the group (Lohmann, 2006), makes the tribe a very suitable model in which to investigate the evolution and development of tendrils.

Here, we study the development of different tendril types in various representatives of the tribe 
Bignonieae, and investigate the patterns of ontogenetic change within an evolutionary framework. We evaluate the historical order of change in morpho-anatomical features associated with tendrils, and suggest potential evolutionary processes that may have led to the diversity of tendrils currently encountered in the tribe. We further relate our findings to genes that are known to regulate leaf development in angiosperms, and discuss the potential role of those genes for the evolution of tendrils in Bignonieae.

\section{Materials ANd Methods}

\section{Ancestral character state reconstructions}

Phylogeny. We used the single tree that resulted from the maximum likelihood analysis of a combined molecular dataset $(P e p \mathrm{C}+n d h \mathrm{~F}$; Lohmann, 2006) as a framework in which to map the ancestral character states of the character "tendril type," and estimate the historical order of appearance of the various tendril types in Bignonieae. This tree included 104 terminals of Bignonieae for which $n d h \mathrm{~F}$ and PepC sequences were obtained for all taxa, plus Perianthomega vellozoi and Callichlamys latifolia, for which only $n d h \mathrm{~F}$ sequences were available. These two additional taxa were included in the analysis with PepC characters coded as "missing data" in order to include representatives of all genera currently recognized in the tribe.

Character coding. Coding of "tendril type" was extracted from the morphological matrix of Lohmann (2003) and Lohmann et al. (2011), which included the exact same 104 terminals as the combined molecular phylogeny (Lohmann, 2006). In addition, Perianthomega vellozoi and Callichlamys latifolia were included in this morphological matrix. Even though Perianthomega presents simple tendrils, the tendrils of this species are twinning petioles rather than modified leaflets and so, tendrils were coded as "absent" in this species. Tendrils of Callichlamys, on the other hand, were coded as "simple". The character "tendril type" and its respective character states were coded as discrete, non-overlapping and multi-state (for further details see Lohmann, 2003; Lohmann et al., 2011). When species presented polymorphic tendril types (T. pyramidatum, A. crucigerum, and A. buccionatorium; Table 1), coding used the majority rule criterion of Wiens (1999), and the most common character state. 
Ancestral character state reconstructions. Reconstructions of the character "tendril type" were conducted under maximum parsimony (Maddison \& Maddison, 1992), and maximum likelihood assumptions (Maddison \& Maddison, 2009), with "tendril type" treated as unordered and unweighted. Parsimony reconstructions used the "all most-pasimonious states" trace option, and implemented the accelerated (ACCTRAN) and delayed (DELTRAN) trace options (Maddison \& Maddison, 1992).

\section{Ontogenetic studies}

Taxon sampling. We selected eleven species (seven genera) that included a wide diversity of tendril morphologies and whose developmental data had greater potential to clarify ambiguities in tendril ancestral character state reconstructions for the ontogenetic studies (Table 1). This sampling scheme was

Table 1. Species sampled in the ontogenetic study, followed by their respective tendril type and phylogenetic placement. For species with polymorphic tendril types, the most common state is indicated first in the column.

\begin{tabular}{lcl}
\hline Species & Tendril type & Phylogenetic placement \\
\hline Bignonia prieurei DC & simple & Clade with ambiguous ancestral tendril type \\
Bignonia callistegioides Cham. & simple & Clade with ambiguous ancestral tendril type \\
Cuspidaria convoluta (Vell.) A.H. Gentry & simple & Clade with a simple tendrilled ancestor \\
Fridericia conjugata (Vell.) L.G. Lohmann & simple & Clade with a simple tendrilled ancestor \\
Fridericia samydoides (Cham.) L.G. Lohmann & simple & Clade with a simple tendrilled ancestor \\
Fridericia speciosa Mart. & simple & Clade with a simple tendrilled ancestor \\
Tanaecium pyramidatum (Rich.) L.G. Lohmann & bifid/trifid & Clade with ambiguous ancestral tendril type \\
Dolichandra unguis-cati (L.) L.G. Lohmann & trifid & Clade with a trifid tendrilled ancestor \\
Mansoa difficilis (Cham.) Bureau \& K. Schum & trifid & Clade with a trifid tendrilled ancestor \\
Amphilophium crucigerum (L.) L.G. Lohmann & trifid/multifid & Clade with a trifid tendrilled ancestor \\
Amphilophium buccinatorium (DC.) L.G. Lohmann & trifid/multifid & Clade with a trifid tendrilled ancestor \\
\hline
\end{tabular}

intended to cover the breath of variation in tendril morphology encountered in Bignonieae, as well as to help resolve ambiguities in the ancestral character state reconstructions. More specifically, we sampled six species with simple tendrils (Bignonia prieurei, Bignonia callistegioides, Cuspidaria convoluta, 
Fridericia conjugata, Fridericia samydoides, and Fridericia speciosa), four species with trifid tendrils (Tanaecium pyramidatum, Dolichandra unguis-cati, Mansoa difficilis, and Amphilophium crucigerum), and one species with multifid tendrils (Amphilophium buccinatorium). Apart from representing a wide diversity of tendril types, these taxa were also selected in order to include representatives of clades with well-established tendril conditions (i.e., homogeneous lineages in terms of tendril morphology and whose ancestral tendril condition was clear), and representatives of clades with ambiguous ancestral tendril types. Samples from clades with well-defined ancestors aimed at characterizing the typical pattern of development of each tendril type. On the other hand, sampling of species belonging to clades with ambiguous ancestral tendril reconstructions aimed at contributing further data for the resolution of these ambiguities.

We used the phylogeny of Bignonieae (Lohmann, 2006) with the character tendril type mapped onto it (Fig. 2) as basis to select taxa for the ontogenetic study. Overall, we sampled four species belonging to two genera with well-established simple tendrils (Cuspidaria and Fridericia), and three species belonging to three genera with well-established trifid tendrils (Dolichandra, Mansoa, and Amphilophium). In addition, we sampled representatives from two genera that presented major ambiguities in the ancestral state reconstructions of tendril type (Bignonia and Tanaecium). Furthermore, our sampling scheme included a species with multifid tendrils (Amphilophium buccinatorium), a species with hooked tendril tips (Dolichandra unguis-cati), and two species with adhesive discs at the tendril tip (Amphilophium buccinatorium and Amphilophium crucigerum) so that a complete picture of tendril development in Bignonieae could be obtained. A complete list of vouchers for all sampled taxa is presented in Table 2.

Ontogenetic studies. Fresh shoot apices were fixed under vacuum for 48 hours in glutaraldehyde and formaldehyde (Karnovsky, 1965) or 4\% paraformaldehyde (Garcês \& Sinha, 2009). Apices were dehydrated in a graded ascending series of ethanol and critical point dried with $\mathrm{CO}_{2}$. Samples were then mounted on SEM stubs with epoxy, sputter-coated with a layer of gold, and observed using scanning electron microscopy (SEM). For the histological analyses, shoot apices were dehydrated in a graded ascending series of tertiary butanol, and gradually embedded in paraffin for the anatomical studies (Johansen, 1940). Embedded specimens were sectioned using a rotary microtome, mounted on slides, and 
stained with toluidine blue (O’Brien et al., 1964). Sections were permanently mounted with "permount" (Fisher Scientific).

Table 2. Taxa sampled for the ontogenetic study, followed by the voucher information and collection localities.

\begin{tabular}{|c|c|c|}
\hline Taxon & Voucher information & Localities \\
\hline \multirow[t]{2}{*}{ Bignonia prieurei DC } & Zuntini 13 (SPF, CVRD) & Brazil. Espírito Santo. Linhares. \\
\hline & & $\begin{array}{l}\text { Companhia Vale do Rio Doce's } \\
\text { reserve. }\end{array}$ \\
\hline Bignonia callistegioides & Sousa-Baena 3 (DAV) & United States. California. Davis. UC- \\
\hline Cham. & & Davis Arboretum Terrace Garden. \\
\hline Cuspidaria convoluta (Vell.) & Pace 48 (SPF) & Brazil. São Paulo. Nova Odessa. \\
\hline A.H. Gentry & & Instituto Plantarum's collection. \\
\hline Fridericia conjugata (Vell.) & Pace $44(\mathrm{SPF})$ & Brazil. São Paulo. Nova Odessa. \\
\hline L.G. Lohmann & & Instituto Plantarum's collection. \\
\hline $\begin{array}{l}\text { Fridericia samydoides } \\
\text { (Cham.) L.G. Lohmann }\end{array}$ & Pace $49(\mathrm{SPF})$ & $\begin{array}{l}\text { Brazil. São Paulo. Nova Odessa. } \\
\text { Instituto Plantarum's collection. }\end{array}$ \\
\hline Fridericia speciosa Mart. & Pace 40 (SPF) & $\begin{array}{l}\text { Brazil. São Paulo. Nova Odessa. } \\
\text { Instituto Plantarum's collection. }\end{array}$ \\
\hline Tanaecium pyramidatum & Pace 14 (SPF) & Brazil. São Paulo. São Paulo. Reserve \\
\hline (Rich.) L.G. Lohmann & Pace 35 (SPF) & of University of São Paulo campus. \\
\hline Dolichandra unguis-cati (L.) & Groppo 322 (SPF) & Brazil. São Paulo. São Paulo. Reserve \\
\hline L.G. Lohmann & & of University of São Paulo campus. \\
\hline
\end{tabular}


Mansoa difficilis (Cham.) $\quad$ Pace 35 (SPF)

Bureau \& K. Schum

Zuntini 4 (SPF, CVRD)
Brazil. São Paulo. São Paulo. Reserve

of University of São Paulo campus.

Brazil. Espírito Santo. Linhares.

Companhia Vale do Rio Doce's

reserve.

Brazil. São Paulo. São Paulo. Reserve

of University of São Paulo campus.

(L.) L.G. Lohmann

Pace 1 (SPF)

United States. California. Davis. UC-

Amphilophium

Sousa-Baena 4 (DAV)

Davis campus.

buccinatorium (DC.) L.G.

Lohmann

\section{RESULTS}

\section{Ancestral character state reconstructions of tendril type}

Maximum parsimony reconstructions. Parsimony ancestral character state reconstructions of "tendril type" using the "all most-pasimonious states" trace option suggest that the ancestral condition for the tribe is ambiguous, with trifid tendrils representing the ancestral condition of the "Core Bignonieae" clade (all Bignonieae excluding Perianthomega), and simple tendrils having evolved at least three times from ancestors with trifid tendrils: once in the ancestor of Adenocalymma, once in the ancestor of Bignonia, and once in the ancestor of the "Fridericia and allies" clade (Fig. 2). Furthermore, at least three independent evolutions of multifid tendrils were reconstructed within Neojobertia, Bignonia, and Manaosella. A single evolution of bifid tendrils was hypothesized within Tanaecium pyramidatum, which presents bifid and trifid tendrils.

Ambiguous reconstructions of tendril type are observed in the ancestral node of Bignonia and at the earliest diverging lineages of the "Fridericia and allies" clade (Fig. 2). Most of these ambiguities are resolved as "simple tendrils" under ACCTRAN optimization, except for the ancestor of Lundia, 


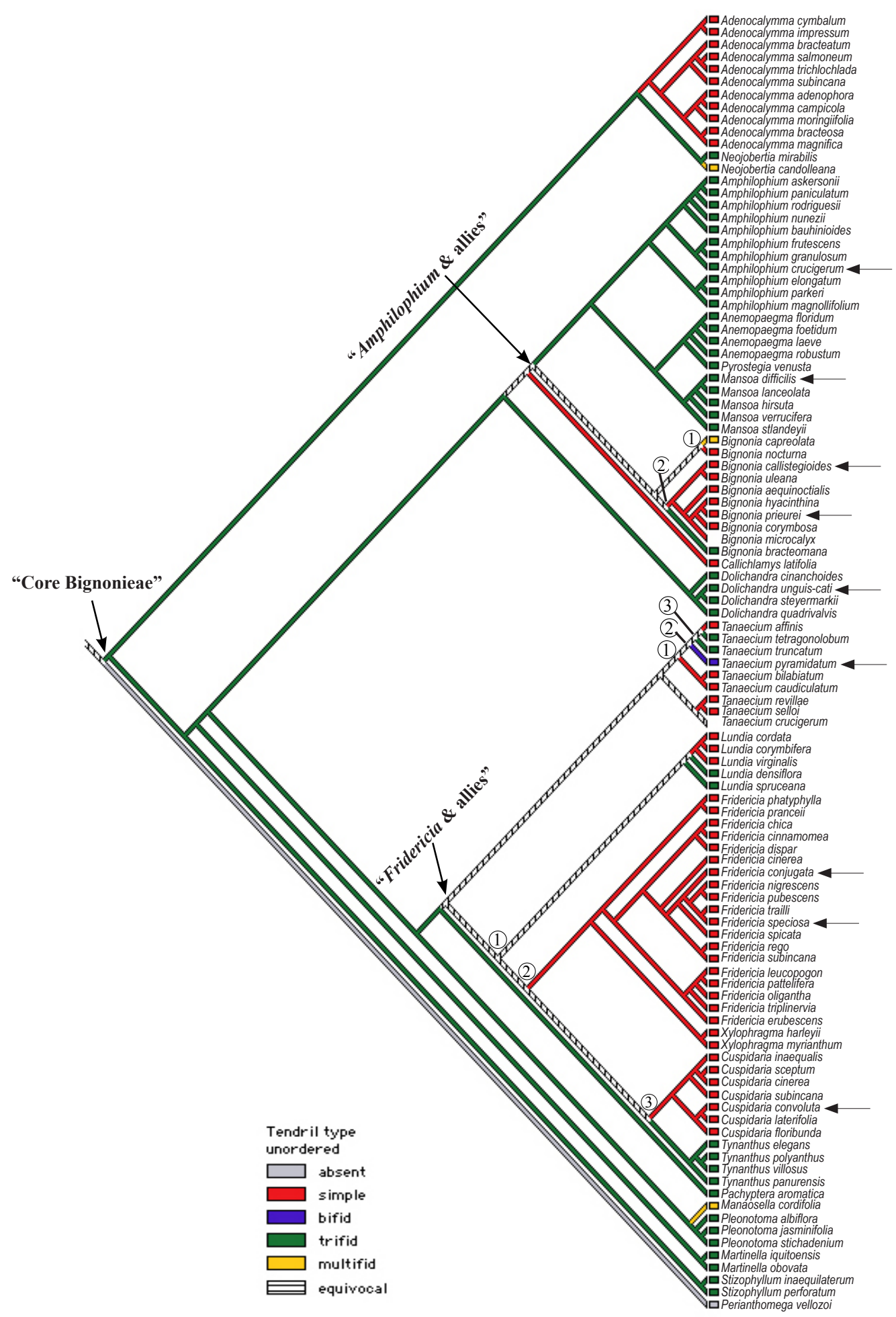

Figure 2. Phylogeny of Bignonieae (from Lohmann, 2006) with parsimony ancestral state reconstruction of the character "tendril type" showing all ambiguous reconstructions. Arrows indicate the phylogenetic placement of species selected for the ontogenetic study, except for Amphilophium buccinatorium and Fridericia samydoides which were not included in this phylogeny. Clade names follow Lohmann (2006). (n)=internal node number "n." 


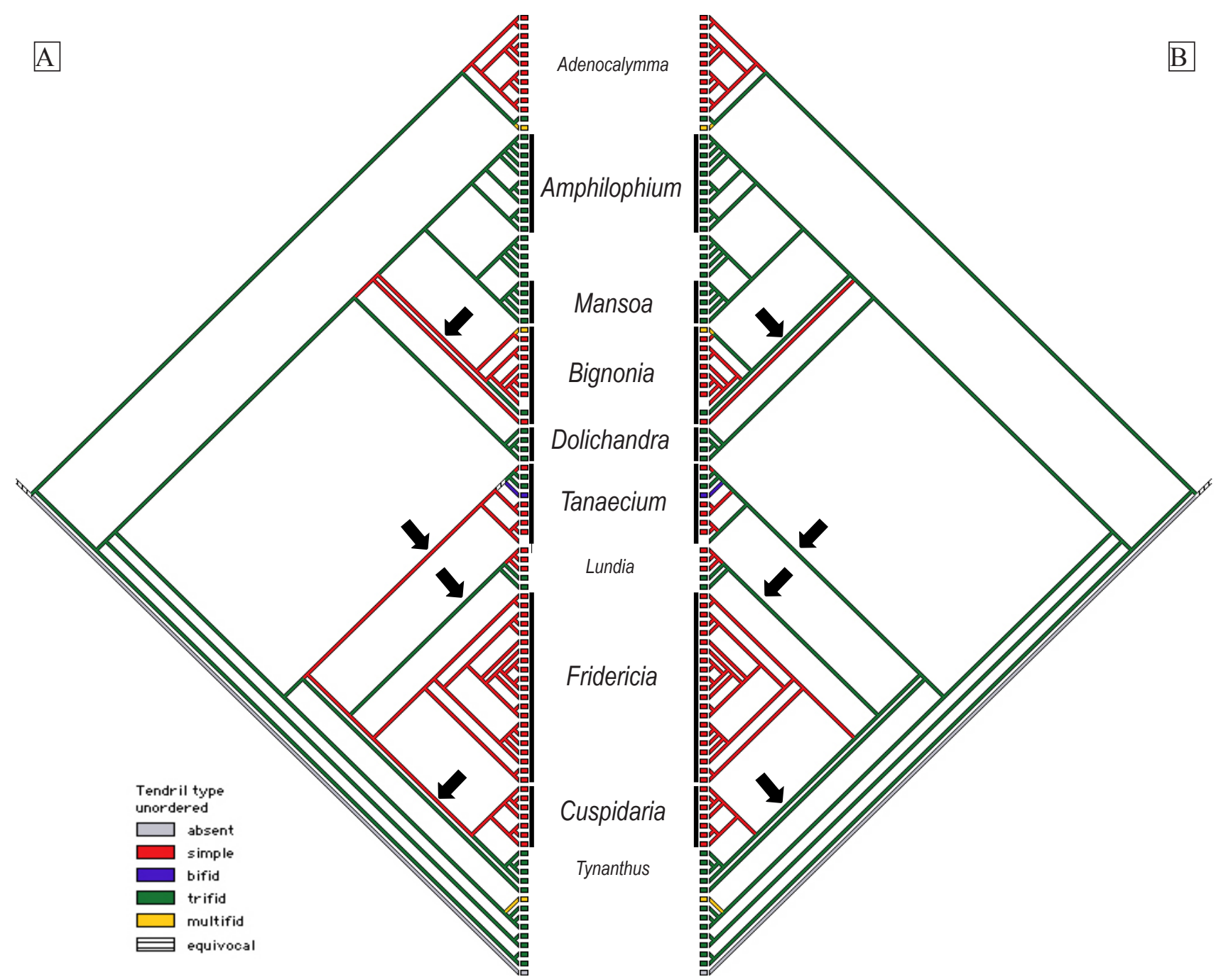

Figure 3. Phylogeny of Bignonieae (from Lohmann, 2006) with parsimony ancestral state reconstruction of the character "tendril type" showing ACCTRAN (A) and DELTRAN (B) optimization schemes. Black bars indicate the genera selected for the ontogenetic study, and black arrows indicate branches with equivocal reconstructions under the "all most-parsimonious states" trace option.

whose tendril type was reconstructed as trifid (Fig. 3A; Table 3). On the other hand, all ambiguities are resolved as "trifid tendrils" under DELTRAN optimizations (Fig. 3B; Table 3). The trifid tendril condition reconstructed at the ancestor of the "Fridericia and allies" clade by DELTRAN implies six independent evolutions of simple tendrils within this clade (three independent evolutions in Tanaecium, one evolution in Lundia, one in Fridericia, and one in Cuspidaria; Fig. 3B). On the other hand, the simple tendril condition reconstructed by ACCTRAN for the ancestor of the "Fridericia and allies" clade, implies three subsequent evolutions of trifid tendrils (one in Tanaecium, one in Lundia, and one in Tynanthus; Fig. 3A). 
Table 3. Tendril types reconstructed at the ancestral node of clades with ambiguous reconstructions under simple parsimony reconstructions. Data for the Bayesian ancestral reconstructions were retrieved from Lohmann et al. (2011). AN=Ancestral Node. IN=Internal Node. For the exact placement of the individual INs, see Fig. 2. - = inexistent node.

\section{DELTRAN ACCTRAN ML BAYESIAN}

\begin{tabular}{|c|c|c|c|c|c|}
\hline \multirow[t]{4}{*}{ Fridericia \& allies clade } & $\mathrm{AN}$ & Trifid & Simple & Simple & Simple \\
\hline & IN 1 & Trifid & Simple & Simple & Simple \\
\hline & IN 2 & Trifid & Simple & Simple & Simple \\
\hline & IN 3 & Trifid & Simple & Simple & Simple \\
\hline \multirow[t]{4}{*}{ Tanaecium } & AN & Trifid & Simple & Simple & Simple \\
\hline & IN 1 & Trifid & Simple & Ambiguous & Simple \\
\hline & IN 2 & Trifid & Simple & Simple & - \\
\hline & IN 3 & Trifid & Ambiguous & Simple & Simple \\
\hline Lundia & AN & Trifid & Trifid & Simple & Simple \\
\hline \multirow[t]{3}{*}{ Bignonia } & AN & Trifid & Simple & Simple & Simple \\
\hline & IN 1 & Trifid & Simple & Trifid & Simple \\
\hline & IN 2 & Trifid & Simple & Trifid & Simple \\
\hline Amphilophium \& allies clade & AN & Trifid & Simple & Trifid & Trifid \\
\hline Callichlamys & AN & Trifid & Simple & Trifid & - \\
\hline
\end{tabular}

Overall, four evolutions of simple tendrils from ancestors with trifid tendrils are hypothesized under ACCTRAN, while ten evolutions of simple tendrils from ancestors with trifid tendrils are hypothesized under DELTRAN (Fig. 3; Table 4). Furthermore, three independent evolutions of multifid tendrils are hypothesized under ACCTRAN and DELTRAN, two of which are derived from ancestors with trifid tendrils and one of which is derived from an ancestor with simple tendrils under both optimization criteria. In addition, five reversals to trifid tendrils from simple tendril ancestors are hypothesized under ACCTRAN, while a single evolution of trifid tendrils (no reversals) is hypothesized under DELTRAN, 


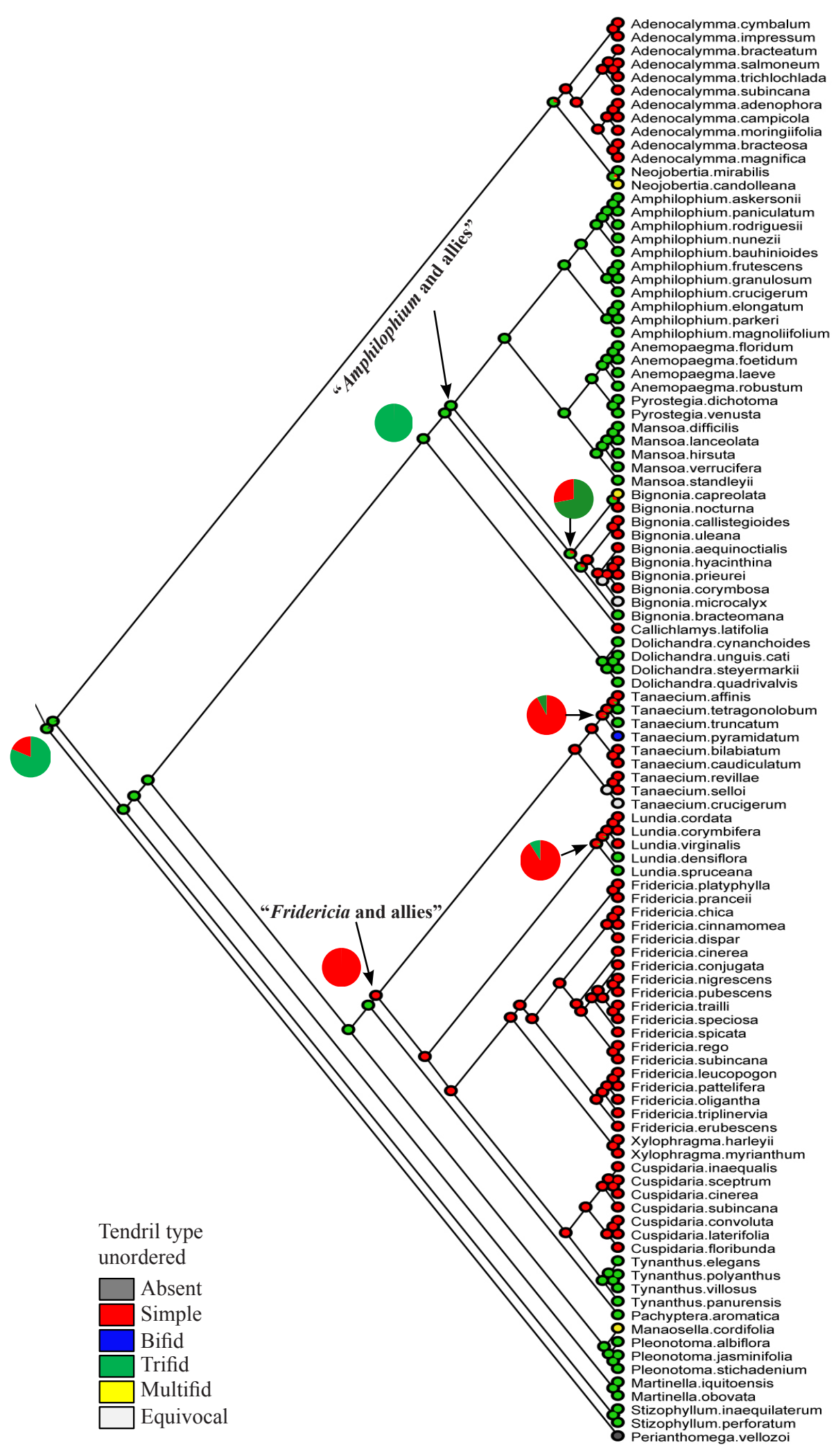

Figure 4. Phylogeny of Bignonieae (from Lohmann, 2006) with maximum likelihood ancestral state reconstruction of the character "tendril type." Pie charts are proportional to the likelihoods of the individual reconstructions. 
Table 4. Number of evolutions of each tendril type under different methods of ancestral character state reconstruction. Data for the Bayesian ancestral reconstructions were retrieved from Lohmann et al. (2011).

\begin{tabular}{|c|c|c|c|c|}
\hline & Simple & Bifid & Trifid & Multifid \\
\hline ACCTRAN & $\begin{array}{c}\mathbf{4} \\
\text { (from ancestor with } \\
\text { trifid tendrils) }\end{array}$ & $\begin{array}{c}1 \\
\text { (from an ancestor } \\
\text { with ambiguous } \\
\text { reconstruction) }\end{array}$ & $\begin{array}{c}\mathbf{6} \\
\text { (1 evolution at the base } \\
\text { of Bignonieae and } 5 \\
\text { reversals from ancestors } \\
\text { with simple tendrils) }\end{array}$ & $\begin{array}{c}\mathbf{3} \\
\text { (2 evolutions from } \\
\text { ancestors with trifid } \\
\text { tendrils and } 1 \text { evolution } \\
\text { from an ancestor with } \\
\text { simple tendrils) }\end{array}$ \\
\hline DELTRAN & $\begin{array}{c}\mathbf{1 0} \\
\text { (from ancestors with } \\
\text { trifid tendrils) }\end{array}$ & $\begin{array}{c}\mathbf{1} \\
\text { (from an ancestor } \\
\text { with trifid } \\
\text { tendrils) }\end{array}$ & $\begin{array}{c}1 \\
\text { (no reversals) }\end{array}$ & $\begin{array}{c}\mathbf{3} \\
\text { (2 evolutions from } \\
\text { ancestors with trifid } \\
\text { tendrils and } 1 \text { evolution } \\
\text { from an ancestor with } \\
\text { simple tendrils) }\end{array}$ \\
\hline ML & $\begin{array}{c}\mathbf{5} \\
\text { (from ancestors with } \\
\text { trifid tendrils) }\end{array}$ & $\begin{array}{c}\mathbf{1} \\
\text { (from an ancestor } \\
\text { with trifid } \\
\text { tendrils) }\end{array}$ & $\begin{array}{c}\mathbf{6} \\
\text { (1 evolution at the base } \\
\text { of Bignonieae and } 5 \\
\text { reversals from ancestors } \\
\text { with simple tendrils) }\end{array}$ & $\begin{array}{c}\mathbf{3} \\
\text { (from ancestors with } \\
\text { trifid tendrils) }\end{array}$ \\
\hline BAYESIAN & $\begin{array}{c}\mathbf{5} \\
\text { (4 evolutions from } \\
\text { ancestors with trifid } \\
\text { tendrils and 1 } \\
\text { evolution from an } \\
\text { ancestor with multifid } \\
\text { tendrils) }\end{array}$ & $\begin{array}{c}\mathbf{1} \\
\text { (from an ancestor } \\
\text { with trifid } \\
\text { tendrils) }\end{array}$ & $\begin{array}{c}\mathbf{4} \\
\text { (1 evolution at the base } \\
\text { of Bignonieae and } 3 \\
\text { reversals from ancestors } \\
\text { with simple tendrils) }\end{array}$ & $\begin{array}{c}\mathbf{3} \\
\text { (2 evolutions from } \\
\text { ancestors with trifid } \\
\text { tendrils and } 1 \text { evolution } \\
\text { from an ancestor with } \\
\text { simple tendrils) }\end{array}$ \\
\hline
\end{tabular}

suggesting that trifid tendrils might be homologous in all lineages. A single evolution of bifid tendrils arising from an ancestor with trifid tendrils is hypothesized within Tanaecium under both optimization criteria. However, ACCTRAN optimization fails to reconstruct the ancestor of an internal node of Tanaecium that gives rise to a heterogeneous clade that includes taxa with simple, bifid and trifid tendrils 
respectively, while DELTRAN optimization reconstructed a trifid tendrilled ancestor for this clade.

Maximum likelihood reconstructions. Maximum likelihood optimizations of the character "tendril type" (Fig. 4) reconstructed an ancestral Bignonieae with trifid tendrils (81,31\%), and four evolutions of simple tendrils (in Adenocalymma, Bignonia, Callichlamys, and in the "Fridericia and allies" clade) from ancestors that presented trifid tendrils. Reversals to trifid tendrils are found in Tanaecium, Lundia, and Tynanthus. Furthermore, three independent evolutions of multifid tendrils (in Neojobertia, Bignonia, and Tanaecium), and one evolution of bifid tendrils (within Tanaecium) are also hypothesized.

ML reconstructed the tendril condition for the most recent ancestor of the clade that includes Amphilophium/Anemopaegma/Pyrostegia/Mansoa/Bignonia as trifid (99,93\%). The tendril condition at deep nodes within this clade were also reconstructed as trifid, as well as was the tendril condition of the ancestor of Bignonia (71,73\%; see pie chart in Fig. 4). Furthermore, two independent evolutions of simple tendrils were hypothesized within Bignonia. On the other hand, the ML reconstruction of tendril type suggested that the ancestor of the "Fridericia and allies" clade very likely presented simple tendrils $(99,96 \%)$, as did the ancestors of most genera within this lineage, except for Tynanthus whose direct ancestor was hypothesized to have trifid tendrils (99,82\%). Apart from Tynanthus, four other reversals to trifid tendrils were hypothesized: two in a subclade within Tanaecium, and two in Lundia. In Tanaecium, a high probability for a simple tendrilled ancestor was hypothesized $(99,96 \%)$, with the direct ancestor of Tanaecium pyramidatum being also reconstructed as simple (92,13\%; pie chart in Fig. 4).

\section{Tendril development}

All species studied have 2-foliolated leaves, with the terminal leaflet modified into a simple, trifid or multifid tendril. In addition, one species with hooked tendril tips (Dolichandra unguis-cati) and two species with adhesive discs at the tendril tip (Amphilophium buccinatorium and A. crucigerum) were also sampled. In all species studied, the leaf primordia emerge from the flanks of the shoot apex as a rounded protuberance (Figs. 5E, 5G, 6G), and become more triangular and flattened as development progresses (Figs. 5A, 6A, 6E, 7A, 10A). At the second stage of development (P2) leaflets are already defined in the leaf primordium, and the tendril is evident as the distal terminal part of the leaf primordium. Because 

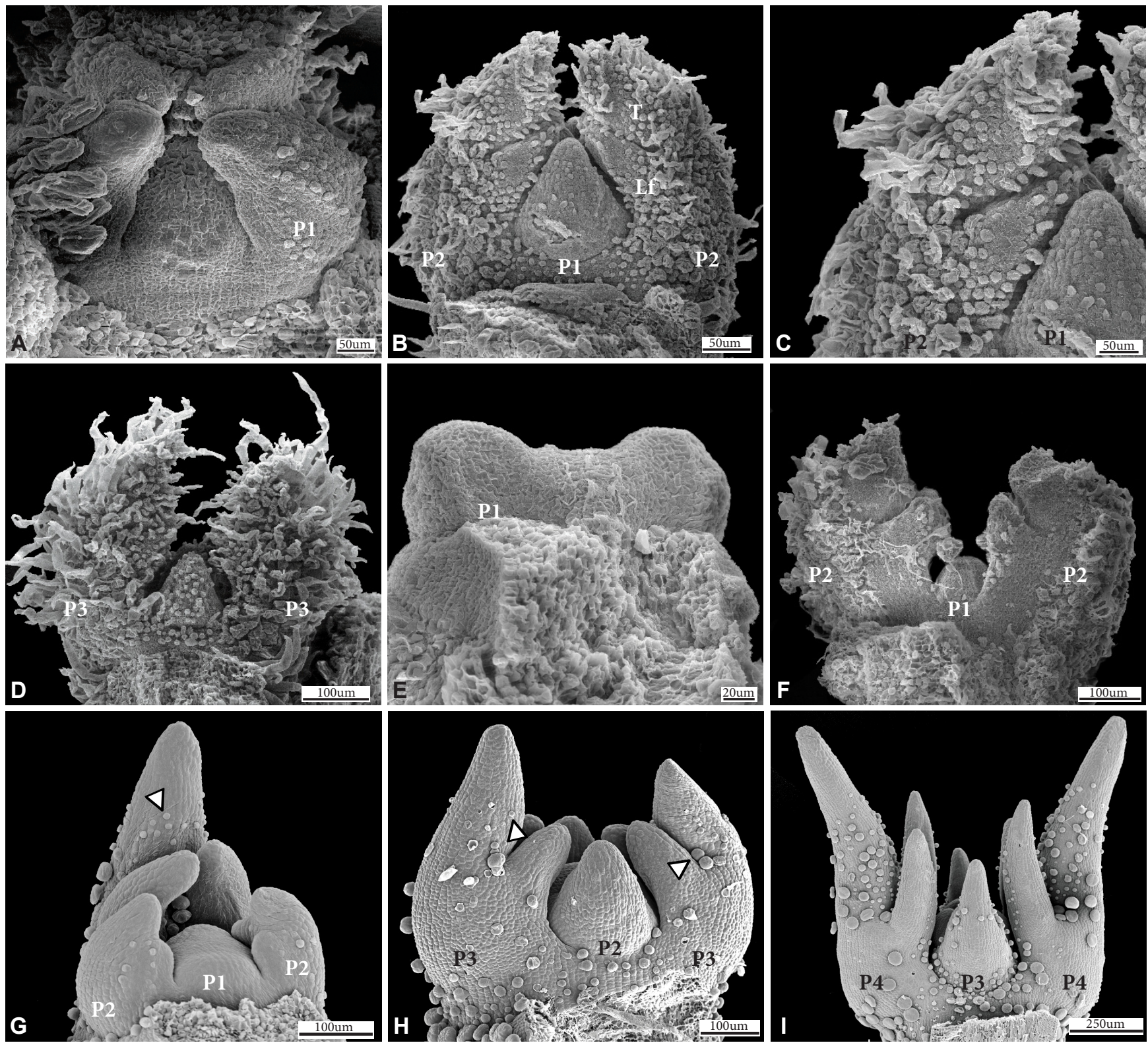

Figure 5. SEM micrographs of shoot apices illustrating the pattern of leaf development in representatives of the tribe Bignonieae (Bignoniaceae) with simple tendrils. A - D. F. speciosa. - A. Shoot apex with P1. - B. Shoot apex with P2. - C. Detail of P2, showing epidermal differentiation in the adaxial surface of the tendril epidermis. - D. Shoot apex with P2 and P3, abaxial and adaxial surfaces of the P3 epidermis covered by trichomes. - E - F. F. conjugata. - E. Shoot apex with P1. - F. Shoot apex with P2. Abaxial surface of the epidermis of a P2 tendril showing high degree of differentiation, and adaxial surface starting to develop trichomes. - G - I. B. callistegioides. - G. Shoot apex with P1, P2 and P3. Arrowhead indicates trichome differentiation in the adaxial surface of P3 tendril epidermis - H. Shoot apex showing P3 in lateral view. Arrowhead indicates trichomes. - I. Shoot apex with P3 and P4, illustrating P4 with well developed leaflets and tendrils and a higher degree of differentiation in the tendril epidermis. $\mathrm{Lf}=$ leaflet, $\mathrm{T}=$ tendril, $\mathrm{Pb}=$ tendril primary branch, $\mathrm{Lb}=$ tendril lateral branch, $\mathrm{Tb}=$ tendril tertiary branch. 

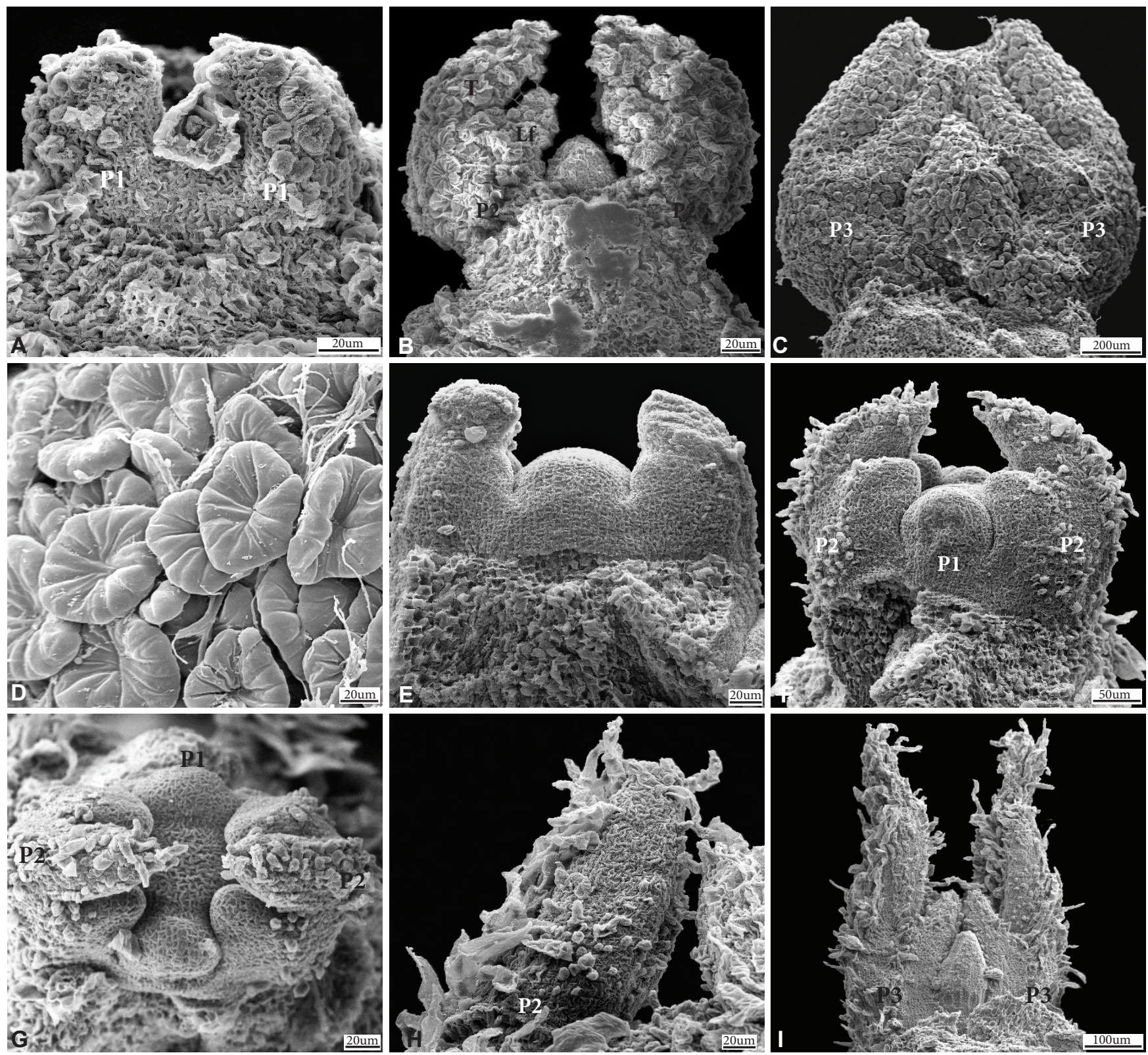

Figure 6. SEM micrographs of shoot apices illustrating the pattern of leaf development in representatives of the tribe Bignonieae (Bignoniaceae) with simple tendrils. A - D. Bignonia prieurei. - A. Shoot apex with P1. - B. Shoot apex with P2, showing leaf epidermis completely differentiated and covered by peltate trichomes. - C. Shoot apex with P2 and P3. - D. Shoot apex with P3, showing detail of a peltate trichome. - E - I. C. convoluta. - E. Shoot apex with P1. - F. Shoot apex with P2. - G. Frontal view of shoot apex, showing epidermal differentiation in P2, mainly in the abaxial surface of the tendril epidermis. - H. Shoot apex with P2 showing tendril detail, and trichomes starting to develop in the adaxial surface of the epidermis. - I. Shoot apex with P2 and P3, showing both surfaces of P3 epidermis covered by trichomes. Lf=leaflet, $\mathrm{T}=$ tendril, $\mathrm{Pb}=$ tendril primary branch, $\mathrm{Lb}=$ tendril lateral branch, $\mathrm{Tb}=$ tendril tertiary branch. 
the plants are 2-foliolated, and the tendril represents a modified terminal leaflet (Figs. 1B-D), the tendril already becomes discernible when the leaflets differentiate from the base at P1 (Figs. 5B-C, 5F, 6B, 6F, 7A, 8A, 10A). Independently of the tendril type, the leaf primordium always develops acropetally.

In all simple tendrilled species studied (Bignonia prieurei, Bignonia callistegioides, Cuspidaria convoluta, Fridericia conjugata, Fridericia samydoides, and Fridericia speciosa) the epidermis becomes precociously covered by trichomes during leaf development (Figs. 5B, 5F, 6B, 6G, 6H), indicating early loss of organogenetic capacity. This differentiation wave starts at the abaxial surface, and continues toward the adaxial surface (Figs. 5A, 5G, 6A). At the second stage of development (P2), leaf primordia show
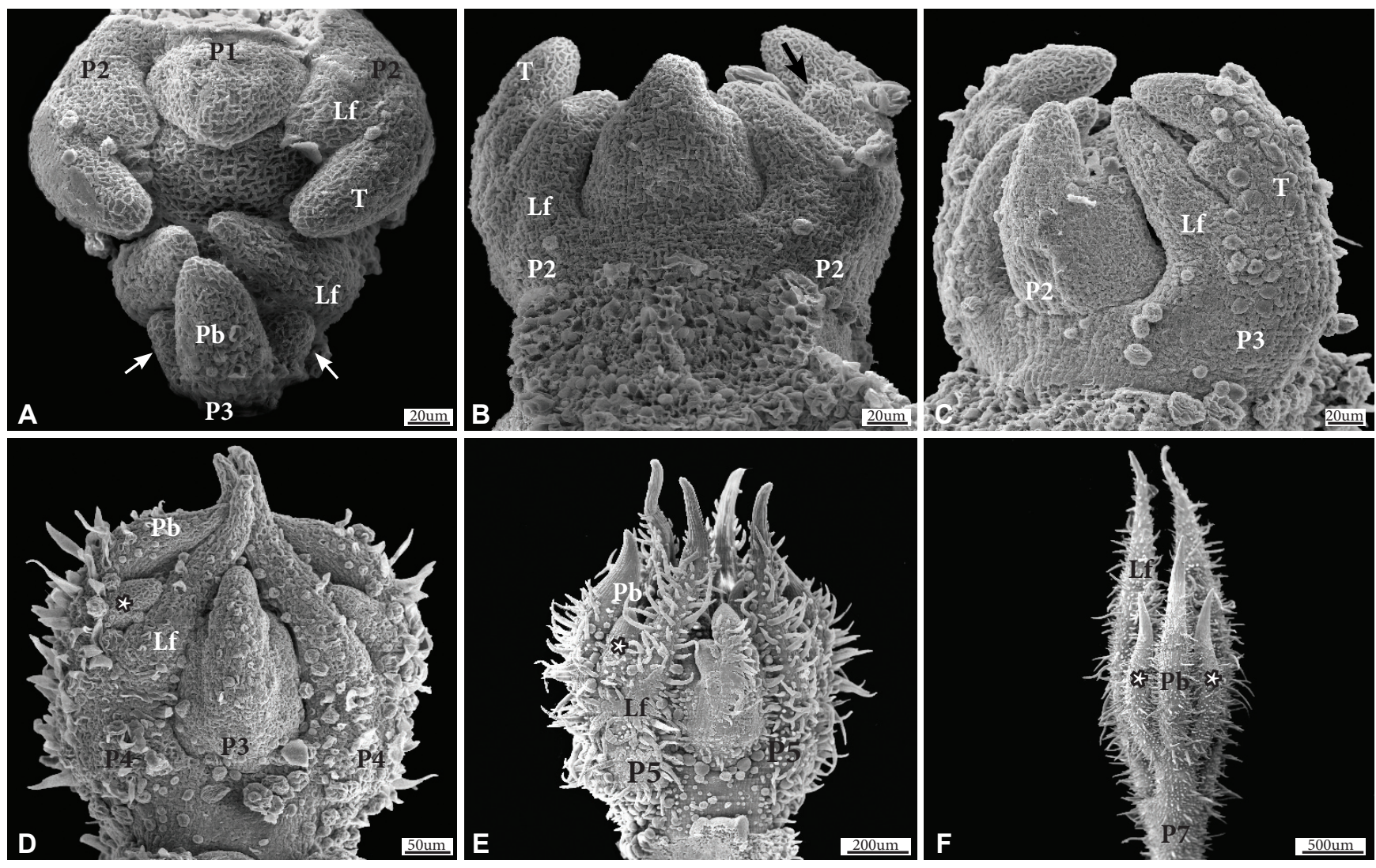

Figure 7. SEM micrographs of a shoot tip of Dolichandra unguis-cati, showing the pattern of development in a trifid tendril. - A. Shoot apex with P1, P2 and P3. Arrows indicate the lateral branches of tendrils in P3. - B. Detail of early P2. Arrows indicate the tissue proliferation that will form the tendril lateral branches. - C. Shoot apex with P3, showing the epidermal differentiation in the tendrils. - D. Shoot apex with P4, showing well developed tendril lateral branches (asterisks) and a higher degree of epidermal differentiation. - E. Shoot apex with P5, showing higher degree of differentiation, with primordia covered by tector and peltate trichomes. Asterisks indicate tendril lateral branches - F. Shoot apex with P7, showing tendril tips starting to become uncinate. Asterisks indicate tendril lateral branches. $\mathrm{Lf}=$ leaflet, $\mathrm{T}=$ tendril, $\mathrm{Pb}=$ tendril primary branch, $\mathrm{Lb}=$ tendril lateral branch, $\mathrm{Tb}=$ tendril tertiary branch. 

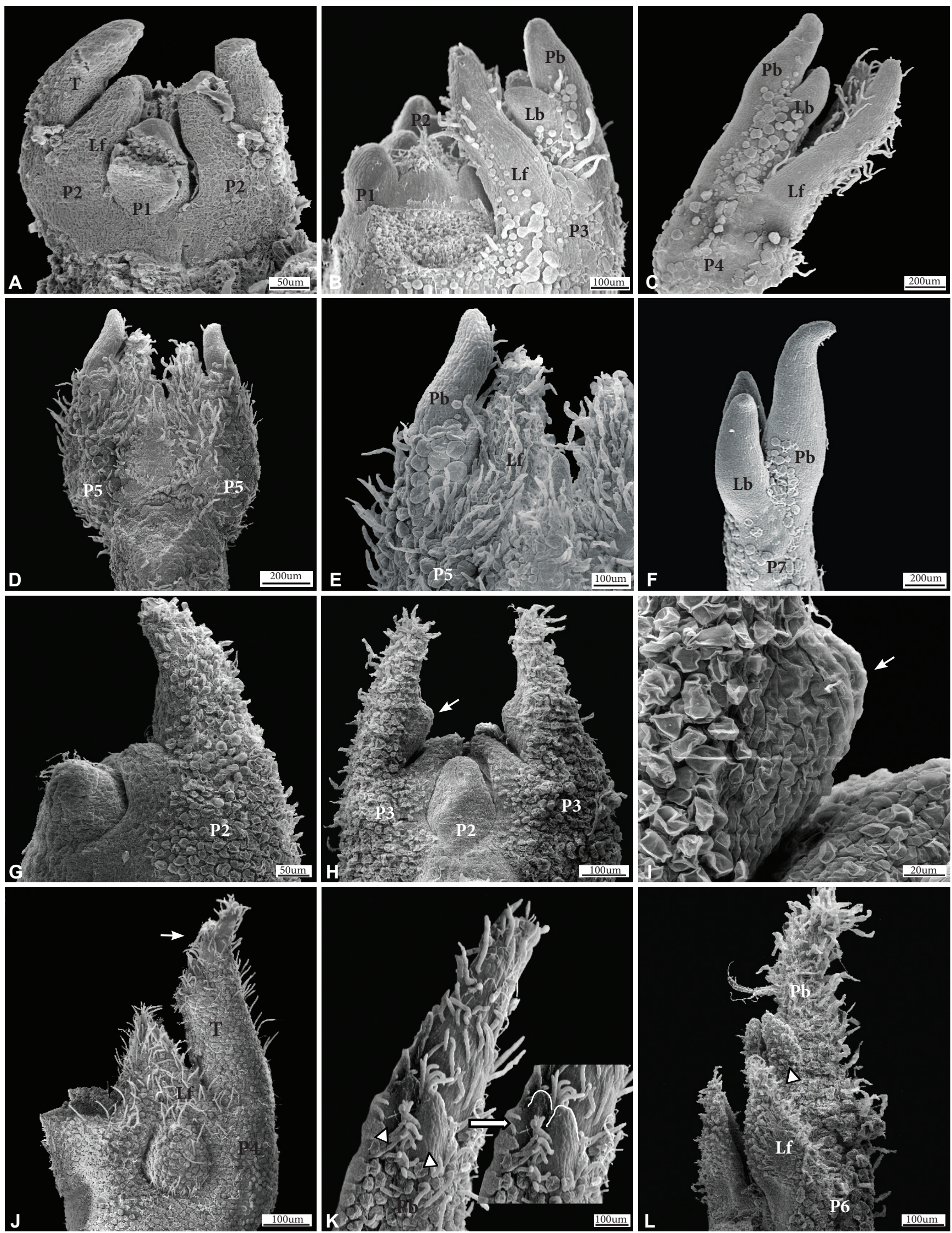
well-developed trichomes on the abaxial surface of the epidermis as well as start to develop trichomes on the adaxial surface (Figs. 5B-C, 6B, 6H). Leaf primordia become progressively covered by trichomes, and both the abaxial and adaxial surfaces of the epidermis show a higher degree of differentiation by P3 (Figs. 5D, 5G, 6C-D, 6I). By the third stage of development, most species already have tendril tips covered by trichomes, except for Bignonia callistegioides in which the tendril tip is always glabrous (Fig. 5I). In Bignonia prieurei, the most pubescent species sampled, the abaxial surface of the epidermis already presents a high density of trichomes at P1, while both surfaces of the epidermis are already completely covered by developing peltate trichomes at P2; these trichomes mature in P3 (Figs. 6A-D).

In all studied species with branched tendrils (Tanaecium pyramidatum, Dolichandra unguis-cati, Mansoa difficilis, Amphilophium buccinatorium, and Amphilophium crucigerum) leaflets are also clearly defined at stage P2, during which time all species start to develop trichomes on the surface of the leaf epidermis (Figs. 7A-B, 8A and 10A). As in the simple tendrilled species, the degree of differentiation of the epidermis is higher on the abaxial surface of the leaf primordium during the early stages of development. In Dolichandra unguis-cati, Mansoa difficilis, Amphilophium crucigerum and A. buccinatorium, the lateral branches of tendrils start to develop at late P2 stage (Fig. 7B), becoming well defined at the third stage of development (Figs. 7A, 7C, 8B, 10B-C). In these species, the formation of tendril lateral branches involves tissues from the lateral flanks of the base of the tendril's primary branch (Figs. 7A-C,

Figure 8. SEM micrographs of shoot apices illustrating the pattern of leaf development in representatives of the tribe Bignonieae (Bignoniaceae) with trifid tendrils . A - F. Mansoa difficilis. - A. Shoot apex with P1 and P2, showing the tendril still unbranched at P2. - B. Shoot apex with P1, P2 and P3, showing the tendril with clearly defined branches at P3. - C. Shoot apex with $\mathrm{P} 4$, illustrating the well-developed tendril lateral branches. $-\mathrm{D}$. Shoot apex with $\mathrm{P} 5$, with the degree of differentiation increasing drastically from the fourth stage (previous figure) to the fifth stage. -E. Shoot apex with P5; detail illustrates tector and peltate trichomes on the tendril epidermis. - F. Shoot apex with P7, with tendril detail showing glabrous branched tip. G - L. Tanaecium pyramidatum. -G. Shoot apex with late P2. Epidermis of tendril abaxial surface showing a high degree of differentiation. - H. Shoot apex with P2 and P3. Arrows indicate the tissue proliferation in the tendril primary branch that will lead to the formation of lateral branches at P3. -I. Detail of P3, showing the beginning of lateral branch formation. Arrow indicates the tissue proliferation in the adaxial surface of the tendril. The epidermis around the tissue protuberance is covered by trichomes. -J. Shoot tip with P4, showing epidermis covered by trichomes and presenting a high degree of differentiation. Tendril lateral branches not clearly defined (arrow). -K. P4, illustrating the tendril tip in detail. Arrowheads indicate the poorly defined lateral tendril branches. White lines delineate the limits of the lateral branches. - L. P6, showing primary branches $(\mathrm{Pb})$ and lateral branches (arrow) disproportionate in size, and completely covered by trichomes. 
$8 \mathrm{~B}, 10 \mathrm{C})$. In taxa with branched tendrils, the rate of epidermal differentiation is generally slower than that observed in the species with simple tendrils (Figs. 7D-E, 8C-E), maintaining their organogenetic capacity for a longer period of time. Furthermore, tendril tips of the taxa with branched tendrils never develop trichomes (Figs. 7F, 8F, 10F). In Dolichandra unguis-cati, tendril tips curve away from the shoot apex in P5 (Fig. 7E), becoming uncinate later, at P9 stage.

In Tanaecium pyramidatum, on the other hand, the tendril lateral branches emerge from the adaxial surface of the tendril primary branch. In this species, the blastozone (i.e., the organogenetic competent region located in the lateral margins of the leaf primordia; Hagemann \& Gleissberg, 1996), seems to have been contracted, occupying only the adaxial portion of the tendril primordium. Contrary to the other species that bear branched tendrils, the lateral branches of Tanaecium pyramidatum are not clearly defined at P3 (Fig. 8H). At this stage, tissue protuberance that gives rise to the tendril lateral
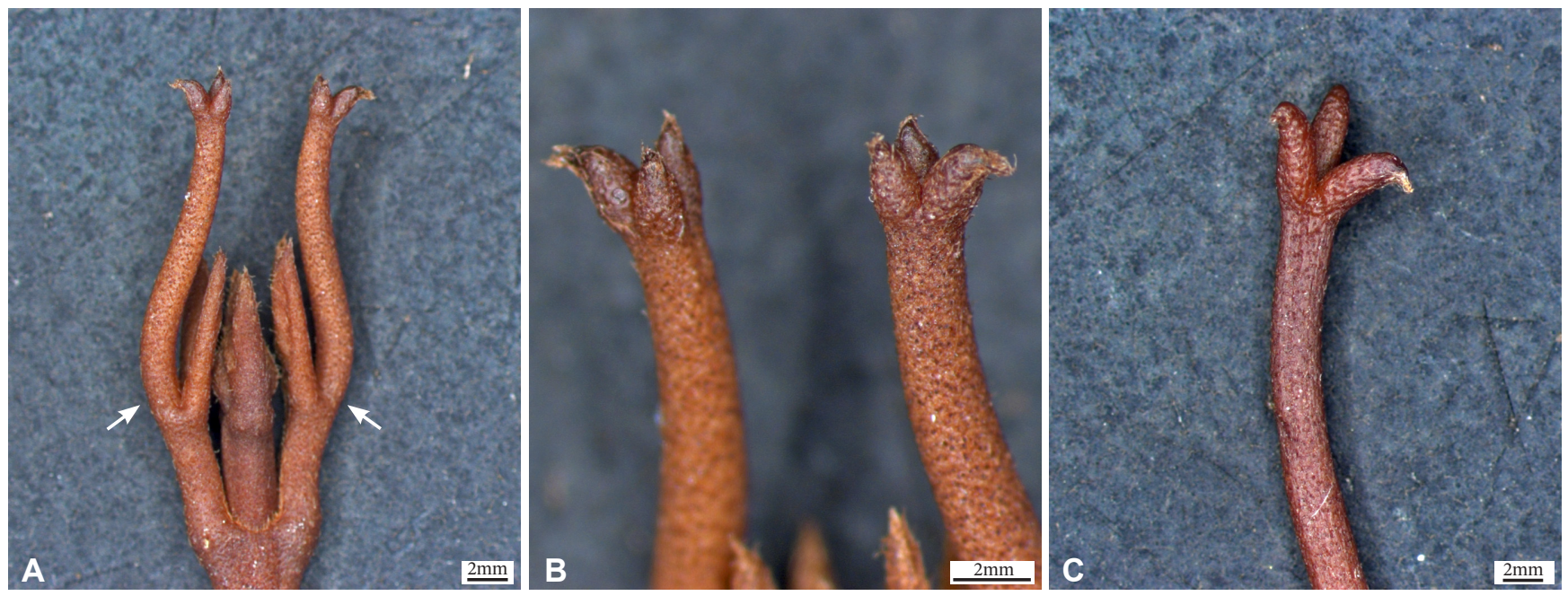

Figure 9. Tanaecium pyramidatum. - A. Shoot apex with P9 (arrows). - B. Higher magnification of the tendril tip at P9. - C. P10, showing a detail of the tendril tip, and the three branches of the tendril with similar sizes.

branches arise at the base of the tendril primary branch (Figs. 8H-I). An elongation of the region below the branch insertion occurs during the transition from P3 to $\mathrm{P} 4$, and the lateral branches are positioned at the tip of the tendril at P4 (Fig. 8J); however, tendrils are not yet clearly defined at this stage (Fig. 8K). It is only at P6 that the lateral branches of these tendrils become clearly visible, although lateral tendril branches remain disproportionate in size to the primary tendril branch at this stage (Fig. 8L).

The leaf primordia of Tanaecium pyramidatum also show an accelerated rate of epidermal 

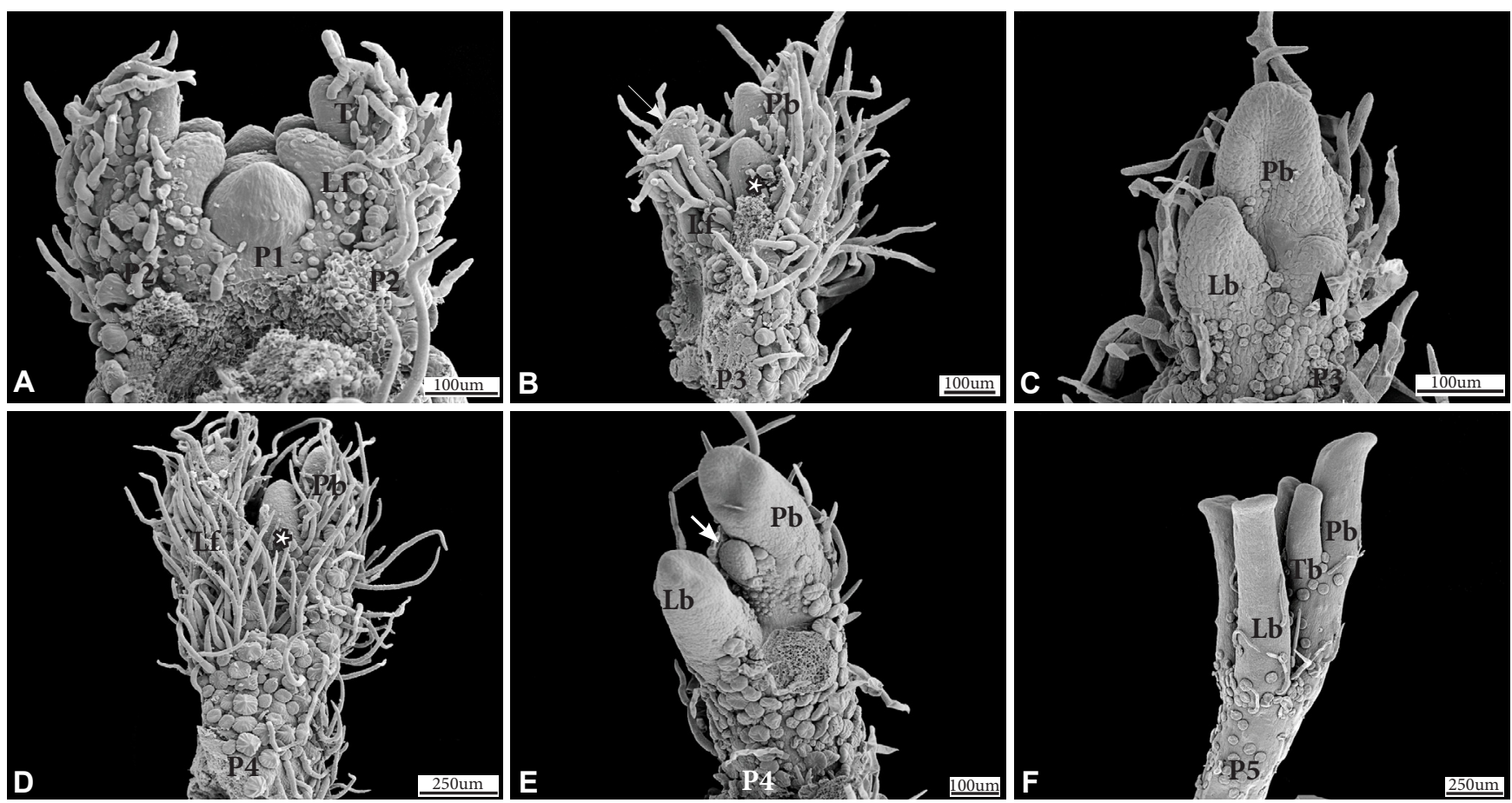

Figure 10. SEM micrographs of Amphilophium buccinatorium illustrating the development of a multifid tendril. - A. Shoot apex with P1 and P2. - B. P3 detached from shoot tip, showing the development of the lateral branches of the tendril (asterisk). - C. P3, showing the development of the asymmetrical lateral branches of the tendril (arrow). - D. P4, tendril lateral branches (asterisk) at a more advanced stage of development. Primordium covered by peltate and long tector trichomes. - E. P4, showing the asymmetrical development of the tertiary branches of the tendril (arrow). - F. P5, showing completely developed multifid tendrils.

differentiation when compared to other species with branched tendrils (e.g., Dolichandra unguis-cati, Mansoa difficilis, Amphilophium buccinatorium, and Amphilophium crucigerum). At stage P3, trichome density is high, reaching the tendril tip, with the region where the lateral branches arise remaining as the only glabrous portion. The degree of epidermal differentiation continues to increase during development, with the whole leaf (including the tip of the lateral branches of the tendril) being covered by trichomes by P6 (Fig. 8L). The other branched tendrilled species (i.e., Dolichandra unguis-cati, Mansoa difficilis, Amphilophium buccinatorium, and Amphilophium crucigerum) present tendril tips that remain glabrous until more advanced stages of development (Figs. 7F, 8F, 10F). The timing of differentiation of the epidermis of the tendrils of Tanaecium pyramidatum resembles the pattern seen in species with simple tendrils (i.e., Bignonia prieurei, Bignonia callistegioides, Cuspidaria convoluta, Fridericia conjugata, Fridericia samydoides, and Fridericia speciosa). Although the lateral branches show a delayed onset, 
the three tendril branches present similar sizes by P9 (Figs. 9A-B). By P10, the lateral branches are welldeveloped and homogeneous in size (Fig. 9C).

Histological analyses indicate that the tissues that proliferate from tendril lateral branches have a different origin in Tanaecium pyramidatum when compared to the other branched tendrilled species
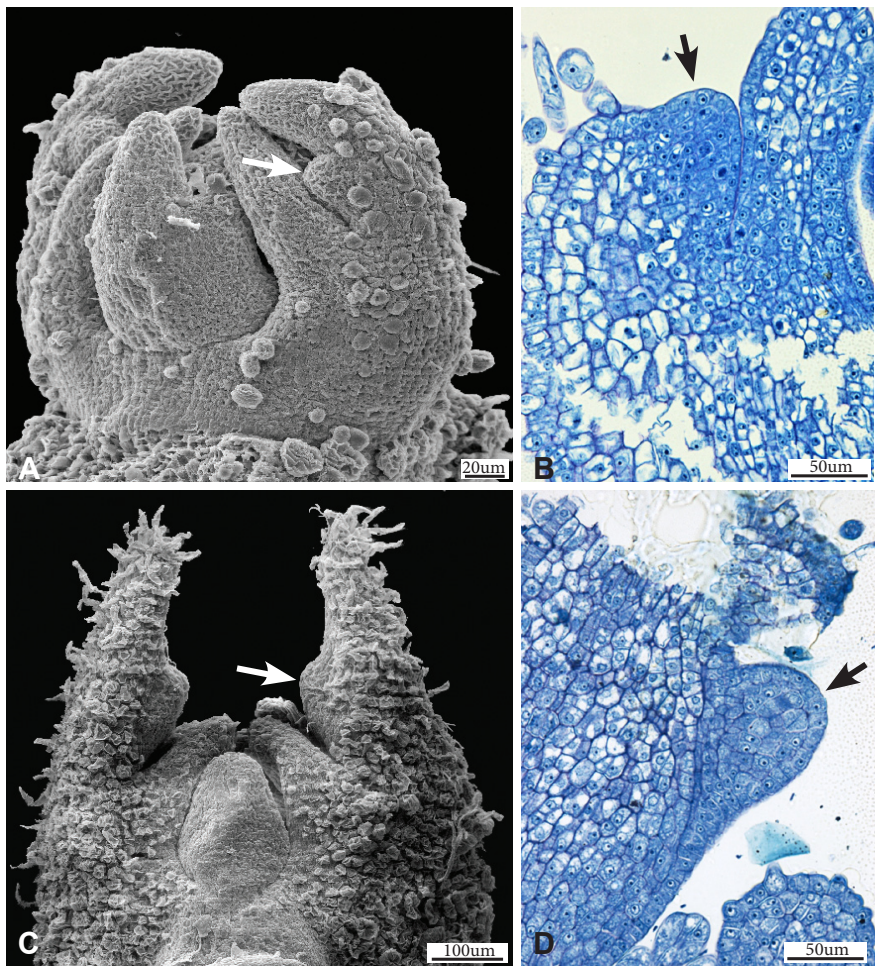

Figure 11. SEM micrographs and histological sections of leaf primordium of Dolichandra unguis-cati and Tanaecium pyramidatum. A - B. Dolichandra unguis-cati. C - D. Tanaecium pyramidatum. $-\mathrm{A}$ and C. Shoot apices with P3, showing trifid tendril with tissue proliferation that will lead to the formation of the tendril lateral branches (arrows). $\mathrm{B}$ and D. Longitudinal sections of the tissue bulge that will form the lateral tendril branches. - B. Formation of the tendril lateral branches involving the division of cells in the epidermal and ground tissue. - D. Tissue that will give rise to tendril lateral branches (arrow) seems to be originated mainly from superficial layers.

discs present in both species of Amphilophium that were investigated arise late in development, when leaves are already mature. investigated. In Dolichandra unguis-cati, Mansoa difficilis, Amphilophium buccinatorium, and Amphilophium crucigerum, the tissue protuberance seems to originate from the epidermis and ground tissue (Figs. 11A-B). On the other hand, this tissue seems to be derived mainly from the superficial in Tanaecium (Figs. 11C-D).

\section{In Amphilophium buccinatorium, the} only species with multifid tendrils investigated, tertiary branches start to emerge from the primary tendril branch during the fourth stage of development, after the tendril lateral branches have already appeared (Figs. 10D-E). In this species, the lateral and tertiary tendril branches may develop in an asymmetrical manner, with tendril branches developing at different rates, resulting in a difference in size between the two lateral and/or tertiary branches (Figs. 10C, 10E). The ramifications of the secondary branches develop later, whenever present. The adhesive 


\section{Discussion}

We studied the evolution of tendrils through an integrated approach that combined ancestral character state reconstructions and detailed developmental data. The character "tendril type" was mapped onto a robust phylogeny of Bignonieae (Lohmann, 2006) using maximum parsimony and maximum likelihood assumptions. We further described tendril development in eleven species that were selected according to their phylogenetic placement and tendril morphologies (i.e., simple, trifid and multifid tendrils). The interpretation of the ontogenetic data in the light of the ancestral character state reconstructions provided key insights for the resolution of ancestral tendril types at nodes in which reconstructions were ambiguous and problematic, especially in Bignonia and Tanaecium. Below we discuss our results and raise hypotheses about evolutionary processes and molecular mechanisms that may have led to the great diversity of tendril types currently seen in Bignonieae.

\section{Ancestral character state reconstructions}

Maximum likelihood reconstructed a trifid tendril condition for the ancestor of the whole tribe $(81,31 \%)$, and for the ancestor of the "Core Bignonieae" clade $(93,68 \%)$. Furthermore, all parsimony optimizations of the character "tendril type" also reconstructed a "trifid tendril" condition for the ancestor of the "Core Bignonieae" clade. On the other hand, parsimony reconstructions led to an ambiguous condition for the ancestor of the whole tribe. The trifid condition reconstructed for the ancestor of the "Core Bignonieae" clade corroborates earlier ancestral character state reconstructions using Bayesian assumptions conducted by Lohmann et al. (2011). However, this study did not include Perianthomega and did not reconstruct the ancestral condition for the whole tribe.

Parsimony reconstructions using the "all most-pasimonious states" trace option (Fig. 2) resulted in several ambiguous reconstructions while parsimony reconstructions using the ACCTRAN and DELTRAN optimization criteria led to mostly unambiguous ancestral character state reconstructions (Fig. 3).In particular, ancestral state reconstructions of tendril type using ACCTRAN optimization (Fig. 3A) suggested that: (1) Simple tendrils evolved four times, always from ancestors that presented trifid tendrils; (2) Bifid tendrils evolved a single time from an ancestor with uncertain tendril type; (3) Trifid 
tendrils evolved six times within the group, once at the base of Bignonieae, which was followed by five reversals from ancestors that presented simple tendrils; and (4) Multifid tendrils evolved at least three times, twice from ancestors that presented trifid tendrils, and once from an ancestor that presented simple tendrils. In contrast, parsimony reconstructions using DELTRAN optimization (Fig. 3B) suggested that: (1) Simple tendrils evolved ten times, always from ancestors that presented trifid tendrils; (2) Bifid tendrils evolved a single time from an ancestor that presented trifid tendrils; (3) Trifid tendrils evolved a single time (no reversals are observed); and (4) Multifid tendrils evolved at least three times, twice from ancestors that presented trifid tendrils, and once from an ancestor that presented simple tendrils.

Furthermore, likelihood reconstructions (Fig. 4) recovered: (1) Five evolutions of simple tendrils, always from ancestors that presented trifid tendrils; (2) A single evolution of bifid tendrils from an ancestor that presented trifid tendrils; (3) Six evolutions of trifid tendrils, once at the base of Bignonieae and five subsequent reversals to trifid tendrils from simple tendrilatted ancestors; and, (4) Three evolutions of mutlifid tendrils, always from ancestors that presented trifid tendrils. Earlier Bayesian reconstructions of "tendril type" (Lohmann et al., 2011) led to the following reconstructions: (1) Six evolutions of simple tendrils that were mostly derived from ancestors that presented trifid tendrils, except for one case in which the ancestor presented multifid tendrils; (2) A single evolution of bifid tendrils from an ancestor that presented a trifid tendril; (3) Four evolutions of trifid tendrils, once at the base of the phylogeny of Bignonieae, plus three reversals from ancestors with simple tendrils; and, (4) Three evolutions of mutlifid tendrils, twice from ancestors with trifid tendrils and once from an ancestor with simple tendrils.

As stated above, all reconstructions hypothesized a single evolution of bifid tendrils (most of which derived from an ancestor that presented trifid tendrils), and three evolutions of multifid tendrils. However, ML and DELTRAN reconstructions suggest that all three evolutions of multifid tendrils derived from ancestors that presented trifid tendrils, while ACCTRAN and Bayesian reconstructions favor two evolutions of multifid tendrils from ancestors that presented trifid tendrils, and one evolution from an ancestor that presented simple tendrils. The number of evolutions of trifid tendrils varied across methods, with a single evolution being hypothesized under DELTRAN, six evolutions under ML, five evolutions under Bayesian, and five evolutions under ACCTRAN. The ancestral tendril type for the 
"Core Bignonieae" clade was reconstructed as "trifid" under all methods, while the ancestor of the whole tribe was ambiguous in the parsimony reconstructions; all subsequent reversals were derived from ancestors that presented simple tendrils. Both ACCTRAN and Bayesian reconstructions hypothesized four evolutions of simple tendrils from ancestors that presented trifid tendrils, while ML reconstructions hypothesized six evolutions. Conversely, DELTRAN favored a much higher number of evolutions of simple tendrils (10), all of which were derived from ancestors that presented simple tendrils.

Overall, ACCTRAN and ML ancestral state reconstructions show very similar patterns of tendril evolution. In contrast, DELTRAN optimizations consistently led to divergent scenarios. Most of the ambiguity associated with the ACCTRAN, DELTRAN and ML reconstructions is associated with the ancestral tendril condition reconstructed for Bignonia, and with the tendril types reconstructed for the earliest diverging lineages of the "Fridericia and allies" clade. In all instances, the same ancestral tendril types were reconstructed by ACCTRAN and Bayesian approached, those of which are generally in agreement with the MLreconstructions (4 out of 6 nodes; Table 3). DELTRAN reconstructions, on the other hand, generally led to conflicting reconstructions. While ACCTRAN optimizations accelerate changes towards the root of the tree, increasing the number of reversals, DELTRAN optimizations delay changes away from the root, increasing independent gains (Swofford \& Maddison, 1987). Although DELTRAN and ACCTRAN optimizations were created as tools of equal value to infer evolutionary patterns, there has been a preference for resolving ambiguous reconstructions using ACCTRAN (Agnarsson \& Miller, 2008). This preference is associated with the notion that reversals are more likely than parallelisms and that the loss of complex traits is more likely than parallel gains (Pinna, 1991; Agnarsson \& Miller, 2008). In this study in particular, ACCTRAN, ML and Bayesian reconstructions favored multiple evolutions of simple tendrils, while DELTRAN favored a single evolution of trifid tendrils and a much higher number of evolutions of simple tendrils (at least 10). Even though the latter scenario is in agreement with the concept that loss of complex traits is more likely than repeated gains, all other reconstructions (ACCTRAN, ML and Bayesian) and ontogenetic data do not favor this hypothesis.

The differences encountered between the different methods of ancestral character state reconstruction were not surprising given that each of these methods is based on a different set of criteria 
and assumptions. For example, maximum parsimony prioritizes the smallest number of evolutionary changes and favors the least complex explanations for an observation. On the other hand, model based approaches such as maximum likelihood favors the most probable explanations for a given dataset, which may or may not represent the most parsimonious explanations (Cunningham et al., 1998; Pagel, 1999; Omland, 1999). Different evolutionary scenarios are reconstructed with the employment of distinct reconstruction methods and assumptions, changing the way we interpret how evolutionary events have occurred and what are the mechanisms responsible for them (Losos, 1999). Integrated approaches that combine ancestral character state reconstructions with ontogenetic data allow us to refine our evolutionary hypotheses as well as to raise subsequent hypotheses about the evolutionary processes and genetic mechanisms that can lead to the patterns of morphological diversity seen in extant species.

\section{Tendril development}

Blastozone activity. All species with simple tendrils studied here showed very similar patterns of development, including an early loss of organogenetic capacity and precocious epidermal differentiation during leaf development. On the other hand, leaf primordia of all species with branched tendrils studied (M. difficilis, D. unguis-cati, A. buccinatorium and A. crucigerum), present slower rates of epidermal differentiation and longer organogenetic capacity than species with simple tendrils. Furthermore, these species present tendril branches that start to appear at late P2 stage (Fig. 7B), becoming clearly defined at P3 (Figs. 7A, 7C, 8B, 10B-C). Species with branched tendrils also show glabrous tendril tips at late stages of development.

In Tanaecium pyramidatum, on the other hand, the three tendril branches become clearly visible only at the sixth stage of development, and a delay in the development of the tendril lateral branches is observed when compared to the other species with branched tendrils. Besides that, T. pyramidatum shows an accelerated rate of epidermal differentiation when compared with the other species with branched tendrils.

In most species with trifid tendrils (M. difficilis, D. unguis-cati, and A. crucigerum) the pattern of activity of the blastozone during the formation of lateral branches of tendrils seems to be a reiteration 
of the activity pattern employed to form leaflets. The blastozone is located in the same relative position (marginal) in tendril primary branch when compared to the leaf primordium and shows a similar pattern of fractionation. Thus, maintenance of the organogenetic competent tissue (blastozone) with similar properties in the primary tendril branch may be responsible for the morphogenesis of the most common leaf type in Bignonieae. Likewise, the ramification pattern of the multifid tendrils of $A$. buccinatorium is not random. These tendrils are trifurcated several times, representing a reiteration of the initial pattern of activity found in the blastozone during leaflet formation.

Conversely, the blastozone is restricted to a portion of the adaxial surface of the tendril primary branch in $T$. pyramidatum. The epidermal differentiation program is activated earlier during the development of tendrils in T. pyramidatum than it is in the other trifid tendrilled species of Bignonieae. On the other hand, the program to promote cell cycle activity in the blastozone is delayed in T. pyramidatum relative to other species with trifid tendrils. Thus, it is possible that the delay seen in the development of the lateral branches of T. pyramidatum may result from a dissociation between the differentiation/ indeterminacy program and the genetic program that promotes cell cycle activity in the blastozone. Thus, when the cell-division cycle activity is triggered in the blastozone at P3, the intense epidermal differentiation that has already progressed restrict the blastozone to a small portion of the adaxial surface of the tendril. Consequently, tendril lateral branches in this species are derived from a smaller pool of "meristematic" cells, resulting in the formation of lateral and primary tendril branches that are disproportional in size (Figs. 8K-L).

Genes involved in the regulation of the blastozone activity. The degree of blade elaboration in compound leaves is determined by the complex and delicate balancing of tissue differentiation and indeterminacy that is dynamically maintained during leaf development. Several genes regulate these processes, and the most general mechanism to maintain indeterminacy seems to involve the expression of KNOX1 genes (Smith et al., 1992; Bharathan et al., 2002). More recently, TCP genes (another family of transcription factors) were found to also play an important role in the control of indeterminate identity during leaf development (Efroni et al., 2008). In particular, TCP genes were shown to play a major role in promoting tissue differentiation in the simple leaves of Arabidopsis thaliana (Efroni et al., 2008). 
Furthermore, increases in TCP expression during the development of complex leaves of tomato result in a premature differentiation of leaf margins, leading to simplification (Ori et al., 2007). One possible hypothesis to explain the interaction between $K N O X 1$ and $T C P$ genes during leaf development is that the acquisition of KNOX1 expression during compound leaf development, coupled with a fine adjustment of the expression of TCP genes, in a developmental stage-dependent manner, would regulate the degree of leaf differentiation as a whole and specify the regions in the blastozone that form lateral outgrowths (Koenig \& Sinha, 2010; Floyd \& Bowman, 2010).

Assuming that KNOXI and TCP genes perform essentially the same functions in Bignonieae, some changes in the expression of TCP genes must have occurred in T. pyramidatum. More specifically, the expression of TCP genes in earlier stages of development or an increased TCP expression may have caused early primordium differentiation and restriction of organogenetic competent tissue, resulting in a delay in the onset of the tendril lateral branches, as well as a delay in the rate of development.

In Pisum sativum, leaf development is controlled by Unifoliolata/LEAFY instead of KNOX1 genes. In other species placed in the same clade (IRLC) leaf development is also controlled by $L E A F Y$, with tendril development being directly associated with TENDRIL-LESS expression, a Class I HDZIP gene (Hofer et al., 2001; Hofer et al., 2009). Bignonieae tendrils are modified terminal leaflets that are similar to pea tendrils, suggesting that $L E A F Y$ could also represent a major regulator of leaf development in representatives of the tribe. However, $S T M(K N O X 1$ gene) is expressed during leaf development in representatives of Bignonieae (M. Sousa-Baena et al., unpubl. data), indicating that it is unlikely that $L E A F Y$ is the primary regulator of leaf development in representatives of Bignonieae.

$A R P$ genes are responsible for the establishment of adaxial identity in developing leaves (Waites et al., 1998). In simple leaved plants $A R P$ genes are expressed in the developing leaves, repressing the expression of KNOX1 (McHale \& Koning, 2004; Champagne \& Sinha, 2004). However, in compound leaves of tomato, $K N O X 1$ and $A R P$ have overlapping expression patterns, suggesting that both genes regulate meristematic functions during leaf development in this species (Kim et al., 2003). Silencing of $A R P$ genes results in the formation of needle-like leaflets in several species of plants (Waites \& Hudson, 1995; Schneeberger et al., 1998; Timmermans et al., 1999; Byrne et al., 2000; McHale \& Koning, 2004). 
Even though needle-like leaflets are morphologically similar to tendrils, studies on the function of $A R P$ genes in pea tendril development showed that this gene does not play an important role in the formation of tendrils in this species (Tattersall et al., 2005). Since pea leaf development is controlled by $L F Y / F L O$ rather than $K N O X 1$ genes, it is reasonable to assume that genes that interact directly with $K N O X 1$ also do not play key roles during leaf development in peas. However, KNOX1 genes are expressed during leaf development of representatives of Bignonieae (M. Sousa-Baena et al., unpubl. data), suggesting that interactions between $S T M$ and $A R P$ genes may be involved in tendril determination in representatives of this clade. Furthermore, other genes that regulate the establishment of ab-adaxial identity (e.g., HD-zipIII genes, $Y A B B Y$ and $K A N A D I)$ may play important roles in tendril development as well.

Alternatively, changes in the hormonal regulation during key leaf developmental stages might be responsible for the delayed development of tendril branches observed in T. pyramidatum. In particular, the production of auxin maxima induces the formation of leaflet primordia along the leaf margin (Barkoulas et al., 2008; Koenig et al., 2009; Koenig \& Sinha, 2010; Floyd \& Bowman, 2010). These auxin peaks are associated with the promotion of cell cycle activity and a shift in the plane of cell division, events that together lead to outgrowth of lateral organs (Koenig \& Sinha, 2010). Hence, it is possible that a delayed auxin maximum might be associated with the delayed development of tendril lateral branches in T. pyramidatum.

\section{Integrating tendril developmental data and ancestral character state reconstructions}

Four out of the six simple tendrilled species studied (C. convoluta, F. conjugata, F. samydoides, and F. speciosa) are inserted within lineages with well-established simple tendrils. The remaining two species (B. prieurei, and B. callistegioides) are inserted within lineages whose ancestral tendril types are ambiguous. In addition, four species with branched tendrils are inserted in clades whose ancestors are unambiguously reconstructed as trifid (M. difficilis, D. unguis-cati, A. buccinatorium, and A. crucigerum;Figs. 2-4). On the other hand, T. pyramidatum, another species with branched tendrils, is inserted within a clade whose ancestor is ambiguously reconstructed as simple or trifid (Figs. 2-4; Table 1). 
Most representatives of Bignonieae present 2-foliolated leaves, with the terminal leaflet modified into a tendril (Lohmann, 2011). Ancestral state reconstructions of tendril type indicated that 2-foliolated leaves with terminal trifid tendrils represent the ancestral condition in the tribe, which was followed by multiple evolutions of different tendrils types, as well as reversals to trifid tendrils. However, ancestral state reconstructions of tendril type based on different algorithms led to ambiguous reconstructions in several nodes (Table 3). In particular, the ancestral tendril condition for Bignonia is ambiguous, as well as the ancestral tendril condition for the "Fridericia and allies" clade and those of several lineages included herein. Because Tanaecium represents the earliest diverging lineage within the "Fridericia and allies" clade, the resolution of the ancestral tendril condition for this genus is critical for a better understanding of the patterns of tendril evolution in all subsequent lineages.

As far as Bignonia is concerned, the tendril condition of the most recent ancestor of this clade was reconstructed as trifid under ML and DELTRAN optimizations, but as simple under ACCTRAN. Earlier Bayesian reconstructions corroborate the ACCTRAN reconstructions (Lohmann et al., 2011). Ontogenetic studies of two species of Bignonia with simple tendrils (B. prieurei, and B. callistegioides) indicated a developmental pattern for these species that is very similar to that of species of Fridericia and Cuspidaria, both of which belong to lineages with well established simple tendrils (i.e., homogeneous lineages in terms of tendril morphology, including simple tendrilled species exclusively, and a clear simple tendrilled ancestor). In particular, these species of Bignonia do not present any traces of lateral tendril branches that could be a reminiscent of a trifid tendrilled ancestor during development. Thus, based on ontogenetic analysis the evolution of simple tendrils must have happened early in the evolutionary history of this genus, suggesting that the ancestral condition for Bignonia is "simple tendril," corroborating the ACCTRAN and Bayesian ancestral character state reconstructions.

As far as Tanaecium is concerned, DELTRAN optimizations reconstructed a trifid tendril condition for the ancestor of this clade, while ML and ACCTRAN reconstructed a simple tendril condition for the ancestor of this clade. Earlier Bayesian reconstructions (Lohmann et al., 2011), corroborate the ML and ACCTRAN reconstructions. Under the latter scenario, the appearance of trifid tendrils in Tanaecium would represent subsequent reversal from simple tendrils. In this case, the simple tendrilled ancestor 
would have suppressed the genetic program that leads to the formation of lateral branches (i.e., cell cycle activity in the blastozone). Ontogenetic studies of T. pyramidatum (a species with trifid tendrils) indicated that this genetic program was indeed reactivated in this species. However, this activation was delayed when compared to other trifid tendrilled species. Furthermore, the pattern and rate of tendril differentiation in T. pyramidatum followed those found in lineages with well-established simple tendrils (i.e., Fridericia, and Cuspidaria), which includes early loss of organogenetic capacity. In other words, earlier stages of development in this species followed those of simple tendrilled taxa, while later stages followed those of trifid tendrilled species, leading to a mosaic of traits that are typical of simple tendrilled taxa (i.e., rapid differentiation of the epidermis of the leaf primordia), and trifid tendrilled taxa (i.e., the retention of organogenetic capacity in the primary branch of the tendril). While the reacquisition of trifid tendrils in this genus is homoplastic, it probably reflects some kind of underlying homology to form lateral branches that must have been retained from ancestral patterns of blastozone fractionation (Rutishauser \& Moline, 2005; Hall, 2003). On the other hand, the maintenance of characteristics that are typical of simple tendrils in the earlier stages of development supports the hypothesis that its direct ancestor would have presented simple tendrils, thus favoring the ML, ACCTRAN and Bayesian ancestral state reconstructions.

\section{Evolutionary processes that may have led to the current diversity in tendril morphology}

The emergence of a new area of scientific research, Evolutionary Developmental Biology (Love \& Raff, 2003; Gilbert, 2003), has prompted the reassessment of several classical concepts, such as homology, homoplasy, heterochrony, homeosis, heterotopy, and novelty (Muller \& Wagner, 1991; Li \& Johnston, 2000; Cronk, 2002; Baum \& Donoghue, 2002; Hall, 2003; Rutishauser \& Moline, 2005; Wagner et al., 2005). In particular, new findings about shared developmental pathways encountered among organisms that are not necessarily closely related led to new definitions of several of these classical concepts (Laubichler \& Maienschein, 2003; Hall, 2003; Cracraft, 2005; Brigandt \& Griffiths, 2007; Jaramillo \& Kramer, 2007; Wagner, 2007). The excitement generated by the possibility of linking gene function to phenotype has brought new interpretation to classical concepts. This facilitates the analysis of 
developmental data in the light of the newly available phylogenies allowing a better understanding of the evolution of development (Raff, 2000). Under this approach it is possible to infer how the dissociation between developmental modules could lead to evolutionary shifts, through processes like heterochrony, heterotopy and homeosis (Wagner et al., 2005; Cronk, 2002; Li \& Johnston, 2000; Baum \& Donoghue, 2002).

As stated above (see discussion under "Blastozone activity" for further details), the pattern of activity of the blastozone during the formation of tendril lateral branches in trifid tendrilled species seems to represent a reiteration of the pattern seen during the formation of leaflets. In the trifid tendrilled species, the blastozone is situated in the same relative position (marginal) in the tendril primary branch when compared with the leaf primordium. On the other hand, the activity and localization of the blastozone is different in T. pyramidatum when compared to other trifid tendrilled species, with the lateral branches showing a delayed onset and growth rate.

In this context, it seems likely that the evolution of trifid tendrils in Tanaecium may have resulted from paedomorphosis by post-displacement (i.e., a delay in the onset of development of some organ or structure in the organism; Alberch et al., 1979). The term post-displacement was coined by zoologists (Alberch et al., 1979), whose study organisms present determinate growth and hence, if the heterochronic structure kept the same developmental rate seen in the ancestor, it would be smaller in the adult animal (Alberch et al., 1979; McNamara, 1986). However, plants have indeterminate growth and sexual maturity cannot be used as an offset reference (Li \& Johnston, 2000). Adult tendrils of Tanaecium have branches with equal size (Fig. 9C), which might result from a delayed developmental onset being consumed by the inherent capacity of plants for indeterminate growth.

The revolutionary synthesis that reunited developmental and evolutionary biology, resulting in the emergence of the new discipline of evolutionary developmental biology, brought about a reappraisal of the concept of heterochrony (Smith, 2003). The use of the term "heterochrony" was extended, and is now also used to describe changes of the developmental timing at the molecular and genetic levels, apart from changes at the morphological level. Changes in the timing, rate or spatial patterns of gene expression during development have been shown to represent one of the underlying causes of phenotypic 
variation (Raff, 1996; Tautz, 2000; Carroll, 2000). Furthermore, heterochronic genes that specifically control developmental timing, have been isolated in plants and animals (Chuck et al., 2007; Sharbel et al., 2010; Efroni et al., 2008; Hunter et al., 2003; Ambros \& Horvitz, 1987; Slack \& Ruvkun, 1998).

In Tanaecium, heterochronic processes such as a delay of the auxin maxima formation in the blastozone coupled with an earlier onset of TCP expression, could be responsible for the evolution of trifid tendrils. Under this hypothesis, opposing types of heterochrony would be acting on tendrils, with post-displacement of auxin maxima formation and earlier onset of differentiation, resulting in a postdisplaced development of tendril lateral branches. It is likely that much of the phenotypic variation that we see in extant species may have arisen through heterochronic processes (Gould, 1992). Indeed, the evolution of one single structure in a certain group of plants can be the result of several, and sometimes contrary, heterochronic processes acting in concert (Alberch et al., 1979; Li \& Johnston, 2000).

Simple tendrils have evolved from trifid tendrils several times in Bignonieae. In these plants the epidermal differentiation is rapid, and the organogenetic competence appears to be lost early in development. Thus, changes in spatio-temporal patterns or levels of TCP expression could also be related to the precocious differentiation of the epidermis in simple tendrilled species, and ultimately responsible for the arising of simple tendrils in Bignonieae. Indeed, it seems that a gradual loss of organogenetic competent tissue in leaf primordia over evolutionary time may have led to the current diversity of tendril morphology.

\section{Conclusions}

The interpretation of tendril ontogenetic data in the light of a robust phylogenetic context revealed some interesting evolutionary trends. First, Mansoa and Dolichandra present trifid tendrils and arose within lineages whose immediate ancestors already had trifid tendrils. In these genera, the three tendril branches were already defined at the third stage of development. Second, Tanaecium belongs to a lineage whose immediate ancestors had simple tendrils. In this genus the three tendril branches are only clearly defined at the sixth stage of development and a considerable delay in tendril development is observed when compared to species with trifid tendrils whose immediate ancestors had trifid tendrils. 
In this species, tendril development is heterochronic, with the evolution of trifid tendrils involving the maintenance of simple tendril characteristics that were present in its immediate ancestor, as well as the reacquisition of traits that are typical of trifid tendrils. Third, Bignonia presents the same developmental pattern as Fridericia and Cuspidaria, two genera that belong to lineages with well-established simple tendrils, indicating that the evolution of simple tendrils happened early in the evolutionary history of these lineages.

Developmental studies contributed data that greatly improved the resolution of the ancestral character state reconstructions of tendril type in Bignonieae. These data corroborated ACCTRAN and Bayesian reconstruction in all instances and generally corroborated ML reconstructions, while did not support DELTRAN reconstructions in any instance. To date, detailed comparisons across methods of ancestral character state reconstructions are still limited, indicating the importance of using multiple methods when reconstructing ancestral character states. Furthermore, integrative approaches, combining data from multiple sources are more likely to lead to more accurate ancestral character state reconstructions and more robust evolutionary hypotheses. Ideally, those hypotheses should be tested at a molecular level, involving spatio-temporal changes in gene expression that may have led to the patterns of phenotypic variation currently observed. Gene expression studies using in situ RNA hybridizations and comparing species with varied tendril morphologies are bringing new insights on the role of STM, ARP, and LEAFY/ FLORICAULA genes in the regulation of tendril development in Bignonieae (M. Sousa-Baena et al., unpubl. data). Further studies using gene silencing and gain-of-function approaches could also contribute important information for a better understanding of the function of those genes in Bignonieae.

\section{LiTERATURE CiTED}

Agnarsson, I. \& J. A. Miller. 2008. Is ACCTRAN better than DELTRAN? Cladistics 24: 1032-1038.

Alberch, P., S. J. Gould, G. F. Oster \& D. B. Wake. 1979. Size and shape in ontogeny and phylogeny. Paleobiology 5: 296-317.

Alcantara, S. \& L. G. Lohmann. 2010. Evolution of floral morphology and pollination system in Bignonieae (Bignoniaceae). Am. J. Bot. 97: 782-796. 
Ambros, V. \& H. R. Horvitz. 1987. The lin-14 locus of Caenorhabditis elegans controls the time of expression of specific postembryonic developmental events. Genes Dev. 1:398-414.

Barkoulas, M., A. Hay, E. Kougioumoutzi \& M. Tsiantis. 2008. A developmental framework for dissected leaf formation in the Arabidopsis relative Cardamine hirsuta. Nat. Genet. 40: 1136-1141.

Baum, D. A. \& M. J. Donoghue. 2002. Transference of function, heterotopy, and the evolution of plant development. Pp. 52-69 in Q. Cronk, R. Bateman \& J. Hawkins (eds.), Developmental Genetics and Plant Evolution. Taylor and Francis, London.

Bharathan, G., T. E. Goliber, C. Moore, S. Kessler, T. Pham \& N. R. Sinha. 2002. Homologies in leaf form inferred from KNOXI gene expression during development. Science 296: 1858-1860.

Bowling, A. J. \& K. C. Vaughn. 2009. Gelatinous fibers are widespread in coiling tendrils and twining vines. Am. J. Bot. 96: 719-727.

Bradshaw, C. J. A., N. S. Sodhi \& B. W. Brook. 2009. Tropical turmoil: a biodiversity tragedy in progress. Front. Ecol. Environ. 7: 79-87.

Brigandt, I. \& P. E. Griffiths. 2007. The importance of homology for biology and philosophy. Biol. \& Phil. 22: 633-641.

Byrne, M.E., R. Barley, M. Curtis, J. M. Arroyo, M. Dunham, A. Hudson \& R. A. Martienssen. 2000. Asymmetric leaves1 mediates leaf patterning and stem cell function in Arabidopsis. Nature 408: $967-$ 971.

Carlquist, S. 1988. Comparative Wood Anatomy - Systematic, Ecological, and Evolutionary Aspects of Dicotyledon Wood. Springer-Verlag, Berlin.

Carroll, S. B. 2000. Endless forms: the evolution of gene regulation and morphological diversity. Cell 101: 577-580.

Champagne, C. \& N. R. Sinha. 2004. Compound leaves: equal to the sum of their parts? Development 131: 4401-4412.

Champagne, C., T. E. Goliber, M. F. Wojciechowski, R. W. Mei, B. T. Townsley, K. Wang, M. M. Paz, R. Geeta \& N. R. Sinha. 2007. Compound leaf development and evolution in the legumes. Plant Cell 19: $3315-3316$.

Chuck, G., A. M. Cigan, K. Saeteurn \& S. Hake. 2007. The heterochronic maize mutant Corngrass1 results from overexpression of a tandem microRNA. Nat. Genet. 39: 544-549.

Cracraft, J. 2005. Phylogeny and evo-devo: characters, homology, and the historical analysis of the evolution of development. Zoology 108: 345-356.

Cronk, Q. C. B. 2002. Perspectives and paradigms in plant evo-devo. Pp. 1-14 in Q. C. B. Cronk, R. M. Bateman \& J. A. Hawkins (eds.), Developmental Genetics and Plant Evolution. Taylor \& Francis, 
London.

Cunningham, C. W., K. E. Omland \& T. H. Oakley. 1998. Reconstructing ancestral character states: a critical reappraisal. Tree 13: 361-366.

D’Arcy, W. G. 1997. A review of the genus Eccremocarpus (Bignoniaceae). Ann. Missouri Bot. Gard. 84: 103-111.

Darwin, C. 1875. The Movements and Habits of Climbing Plants. 2d ed. John Murray, London.

DeMason, D. A. \& R. Chawla. 2004. Roles for auxin during morphogenesis of the compound leaves of pea (Pisum sativum). Planta 218: 435-448.

Dobbins, D. R. 1971. Studies on the anomalous cambial activity in Doxantha unguis-cati (Bignoniaceae). II. a case of differential production of secondary tissues. Am. J. Bot. 58: 697-705.

Dobbins, D.R. \& J.B. Fisher. 1986. Wound responses in girdled stems of lianas. Bot. Gaz. 147: 278-289.

Efroni, I., E. Blum, A. Goldshmidt \& Y. Eshed. 2008. A protracted and dynamic maturation schedule underlies Arabidopsis leaf development. Plant Cell 20: 2293-2306.

Engelberth, E. 2003. Mechanosensing and signal transduction in tendrils. Adv. Space Res. 32: 16111619.

Floyd, S. K. \& J. L. Bowman. 2010. Gene expression patterns in seed plant shoot meristems and leaves: homoplasy or homology? J. Plant Res. 123: 43-55.

Gabrielli, A. C. 1993. Estrutura caulinar secundária em Pyrostegia venusta (Ker.) Miers - Bignoniaceae. Rev. Bras. Bot. 16: 167-173.

Garcês, H. M. P. \& N. R. Sinha. 2009. Fixing and sectioning tissue from the Plant Kalanchö̈ daigremontiana. Cold Spring Harbor Protocols, Woods Hole.

Gasson, P. \& D. R. Dobbins. 1991. Wood anatomy of the Bignoniaceae, with a comparison of trees and lianas. IAWA Bull. 12: 389-417.

Gentry, A. H. 1980. Bignoniaceae. Part I (tribes Crescentieae and Tourrettieae). Flora Neotropica Monographs 25: 1-150.

Gentry, A. H. 1991. The distribution and evolution of climbing plants. Pp. 3-49 in F. E. Putz \& H. A. Mooney (eds.), The biology of vines. Cambridge University Press, Cambridge.

Gilbert, S. F. 2003. The morphogenesis of evolutionary developmental biology. Int. J. Dev. Biol. 47: 467-477.

Gould, K. S., E. G. Cutter \& J. P. Young. 1994. The determination of pea leaves, leaflets, and tendrils. Am. J. Bot. 81: 352-360.

Gould, S. J. 1992. Ontogeny and phylogeny - revisited and reunited. Bioessays 14: 275-279. 
Gourlay, C. W., J. M. I. Hofer \& T. H. N. Ellis. 2000. Pea compound leaf architecture is regulated by interactions among the genes UNIFOLIOLATA, COCHLEATA, AFILA and TENDRIL-LESS. Plant Cell 12: 1279-1294.

Hagemann, W. \& S. Gleissberg. 1996. Organogenetic capacity of leaves: the significance of marginal blastozones in angiosperms. Plant Syst. Evol. 199: 121-152.

Hall, B. K. 2003. Descent with modification: the unity underlying homology and homoplasy as seen through an analysis of development and evolution. Biol. Rev. 78: 409-433.

Hofer, J. M. I. \& T. H. N. Ellis. 1998. The genetic control of patterning in pea leaves. Trends P1. Sci. 3: 439-444.

Hofer, J. M. I., C. W. Gourlay, A. Michael \& T. H. N. Ellis. 2001. Expression of a class 1 Knottedl-like homeobox gene is down-regulated in pea compound leaf primordia. Plant Mol. Biol. 45: 387-398.

Hofer, J., L. Turner, C. Moreau, M. Ambrose, P. Isaac, S. Butcher, J. Weller, A. Dupin, M. Dalmais, C. Le Signor, A. Bendahmane \& N. Ellis. 2009. Tendril-less regulates tendril formation in pea leaves. Plant Cell 21: 420-428.

Hunter, C., H. Sun \& R. S. Poethig. 2003. The Arabidopsis heterochronic gene ZIPPY is an ARGONAUTE family member. Curr. Biol. 13: 1734-1739.

Isnard, S. \& W. K. Silk. 2009. Moving with climbing plants from Charles Darwin's time into the $21^{\text {st }}$ century. Am. J. Bot. 96: 1205-1221.

Jaffe, M. J. \& A. W. Galston. 1968. Physiological studies on pea tendrils .V. Membrane changes and water movement associated with contact coiling. Plant Physiol. 43: 537-542.

Jaffe, M. J. 1975. Role of auxin in early events of contact coiling of tendrils. Plant Sci. Lett. 5: 217-225.

Jaffe, M. J., A. C. Leopold \& R. C. Staples. 2002. Thigmo responses in plants and fungi. Am. J. Bot. 89: 375-382.

Jaramillo, M. A. \& E. M. Kramer. 2007. The role of developmental genetics in understanding homology and morphological evolution in plants. Int. J. Plant Sci. 168: 61-72.

Johansen, D. A. 1940. Plant microtechnique. McGraw-Hill Book Co. Inc., New York.

Junker, S. 1976. Auxin transport in tendril segments of Passiflora caerulea. Physiol. Plant. 37: 258-262.

Karnovsky M. J. 1965. A formaldehyde-glutaraldehyde fixative of high osmolality for use in electron microscopy. J. Cell Biol. 27: 137-138.

Kim, M., S. McCormick, M. Timmermans \& N. R. Sinha. 2003. The expression domain of PHANTASTICA determines leaflet placement in compound leaves. Nature 424: 438-443.

Koenig, D. \& N. Sinha. 2010. Evolution of leaf shape: a pattern emerges. Curr. Top. Dev. Biol. 91: 169183. 
Koenig, D., E. Bayer, J. Kang, C. Kuhlemeier \& N. Sinha. 2009. Auxin patterns Solanum lycopersicum leaf morphogenesis. Development 136: 2997-3006.

Laubichler, M. D. \& J. Maienschein. 2003. Ontogeny, anatomy, and the problem of homology: Carl Gegenbaur and the American tradition of cell lineages. Theory Biosci. 122: 194-203.

Li, P. \& M. O. Johnston. 2000. Heterochrony in plant evolutionary studies through the twentieth century. Bot. Rev. 66: 57-88.

Liss, H. \& E. W. Weiler. 1994. Ion-translocating atpases in tendrils of Bryonia dioica Jacq. Planta 194: 169-180.

Lohmann, L. G. \& C. Ulloa. 2006 onwards. Bignoniaceae in iPlants prototype checklist. Available at http://www.iplants.org (accessed 02 October 2006 13:32 GMT).

Lohmann, L. G. 2003. Phylogeny, classification, morphological diversification and biogeography of Bignonieae (Bignoniaceae, Lamiales). Ph.D. Dissertation. University of Missouri-St. Louis, St. Louis, Missouri, USA.

Lohmann, L. G. 2004. Bignoniaceae. Pp. 51-53 in N. Smith, S. A. Mori, A. Henderson, D. W. Stevenson \& S. V. Heald (eds.), Flowering Plants of the Neotropics. Princeton University Press and the New York Botanical Garden, Princeton.

Lohmann, L. G. 2006. Untangling the phylogeny of neotropical lianas (Bignonieae, Bignoniaceae). Am. J. Bot. 93:304-318.

Lohmann, L. G. 2011. A new generic classification of Bignonieae (Bignoniaceae) based on molecular phylogenetic data and morphological synapomorphies. Ann. Missouri Bot. Gard. In press.

Lohmann, L. G., P. F. Stevens \& E. A. Kellogg. 2011. Twists in the phylogeny of Neotropical lianas (Bignonieae, Bignoniaceae): Insights from morphology and molecules. Syst. Bot. In press.

Losos, J. B. 1999. Commentaries - Uncertainty in the reconstruction of ancestral character states and limitations on the use of phylogenetic comparative methods. Anim. Behav. 58: 1319-1324.

Love, A. C. \& R. A. Raff. 2003. Knowing your ancestors: themes in the history of evo-devo. Evol. Dev. 5: $327-330$.

Maddison, W. P. \& D. R. Maddison. 1992. MacClade: Analysis of phylogeny and character evolution, version 3.01. Sinauer. Sunderland, Massachusetts, USA.

Maddison, W.P. \& D.R. Maddison. 2009. Mesquite: a modular system for evolutionary analysis. Version 2.72. Available at http://mesquiteproject.org

McHale, N. A. \& R. E. Koning. 2004. PHANTASTICA regulates development of the adaxial mesophyll in Nicotiana leaves. Plant Cell 16: 1251-1262.

McNamara, K. J. 1986. A guide to the nomenclature of heterochrony. J. Paleontol. 60: 4-13. 
Meloche, C. G., J. P. Knox \& K. C. Vaughn. 2007. A cortical band of gelatinous fibers causes the coiling of redvine tendrils: a model based upon cytochemical and immunocytochemical studies. Planta 225: 485-498.

Monshausen, G. B., S. J. Swanson \& S. Gilroy. 2008. Touch sensing and thigmotropism. Pp. $91-122$ in S. Gilroy \& P. H. Masson (eds.), Plant Tropisms. Blackwell Publishing, Oxford.

Muller, G. B. \& G. P. Wagner. 1991. Novelty in evolution - restructuring the concept. Ann. Rev. Ecol. Syst. 22: 229-256.

O’Brien, T. P., N. Feder \& M. E. McCully. 1964. Polychromatic staining of plant cell walls by Toluidine blue O. Protoplasma 59: 368-373.

Olmstead, R. G., M. L. Zjhra, L. G. Lohmann, S. O. Grose \& A. J. Eckert. 2009. A molecular phylogeny and classification of Bignoniaceae. Am. J. Bot. 96: 1731-1743.

Omland, K. E. 1999. The assumptions and challenges of ancestral state reconstructions. Syst. Biol. 48: 604-611.

Ori, N., A. R. Cohen, A. Etzioni, A. Brand, O. Yanai, S. Shleizer, N. Menda, Z. Amsellem, I. Efroni, I. Pekker, J. P. Alvarez, E. Blum, D. Zamir \& Y. Eshed. 2007. Regulation of LANCEOLATE by miR319 is required for compound-leaf development in tomato. Nat. Genet. 39: 787-791.

Pace, M. R., Lohmann, L.G. \& V. Angyalossy. 2009. The rise and evolution of the cambial variant in Bignonieae (Bignoniaceae). Evol. Dev. 11: 465-479.

Pace, M.R., Lohmann, L.G. \& V. Angyalossy. 2011. Evolution of disparity between the regular and variant phloem in Bignonieae (Bignoniaceae). Am. J. Bot. 98: 602-618.

Pagel, M. 1999. The maximum likelihood approach to reconstructing ancestral character states of discrete characters on phylogenies. Syst. Biol. 48: 612-622.

Perez-Salicrup, D. R. 2001. Effect of liana cutting on tree regeneration in a liana forest in Amazonian Bolivia. Ecology 82: 389-396.

Pinna, M. C. C. 1991. Concepts and tests of homology in the cladistic paradigm. Cladistics 7: 367-394.

Putz, F. E. \& N. M. Holbrook. 1991. Biomechanical studies of vines. Pp. 73-97 in F. E. Putz \& H. A. Mooney (eds.), The Biology of Vines. Cambridge University Press, New York.

Raff, R. A. 1996. The Shape of Life: Genes, Development and the Evolution of Animal Form. Chicago Univ. Press, Chicago.

Raff, R. A. 2000. Evo-devo: the evolution of a new discipline. Nature 1: 74-79.

Riehl, T. E. \& M. J. Jaffe. 1982. Physiological studies on pea tendrils .13. Respiration is necessary for contact coiling. Physiol. Plant. 55: 192-196.

Rutishauser, R. \& P. Moline. 2005. Evo-devo and the search for homology ("sameness") in biological 
systems. Theory Biosci. 124: 213-241.

Schenck, H. 1893. Beiträge zur Biologie und Anatomie der Lianen im Besonderen der in Brasilien einheimischen Arten. II. Theil. Beiträge zur Anatomie der Lianen in A. F. W. Schimper (ed.), Botanische Mittheilungen aus den Tropen. Gustav Fisher, Jena.

Schneeberger, R., M. Tsiantis, M. Freeling \& J. A. Langdale. 1998. The rough sheath2 gene negatively regulates homeobox gene expression during maize leaf development. Development 125: 2857-2865.

Schnitzer, S. A. \& F. Bongers. 2002. The ecology of lianas and their role in forests. Trends Ecol. Evol. 17: 223-230.

Schnitzer, S. A. 2005. A mechanistic explanation for global patterns of liana abundance and distribution. Am. Nat. 166: 262-276.

Sharbel, T. F., M. L. Voigt, J. M. Corral, G. Galla, J. Kumlehn, C. Klukas, F. Schreiber, H. Vogel \& B. Rotter. 2010. Apomictic and sexual ovules of Boechera display heterochronic global gene expression patterns. Plant Cell 22: 655-671.

Sinha, N. R. 1999. Leaf development in angiosperms. Ann. Rev. Plant Physiol. 50: 419-446.

Slack, F. \& G. Ruvkun. 1998. Heterochronic genes in development and evolution. Biol. Bull-Us 195: 375-376.

Smith, K. K. 2003. Time's arrow: heterochrony and the evolution of development. Int. J. Dev. Biol. 47: 613-621.

Solereder, H. 1908. Systematic Anatomy of the Dicotyledons, Vols. I and II. Clarenton Press, Oxford.

Smith, L. G., B. Greene, B. Veit \& S. Hake. 1992. A dominant mutation in the maize homeobox gene, Knotted-1, causes its ectopic expression in leaf cells with altered fates. Development 116: 21-30.

Spangler, R. E. \& R. G. Olmstead. 1999. Phylogenetic analysis of Bignoniaceae based on the cpDNA gene sequences $r b c \mathrm{~L}$ and $n d h \mathrm{~F}$. Ann. Missouri Bot. Gard. 86: 33-46.

Swofford, D. L. \& W. P. Maddison. 1987. Reconstructing ancestral character states under Wagner parsimony. Math. Biosci. 87: 199-229.

Tattersall, A. D., L. Turner, M. R. Knox, M. J. Ambrose, T. H. N. Ellis \& J. M. I. Hofer. 2005. The mutant crispa reveals multiple roles for PHANTASTICA in pea compound leaf development. Cell 17: 10461060.

Tautz, D. 2002. Evo-devo graduates to new levels. Trends Genet. 18: 66-67.

Timmermans, M.C.P., A. Hudson, P. W. Becraft \& T. Nelson. 1999. ROUGH SHEATH2: A myb protein that represses knox homeobox genes in maize lateral organ primordia. Science 284: 151-153.

van der Heijden, G. M. F., T. R. Feldpausch, A. D. Herrero, N. K. van der Velden \& O. L. Phillips. 2010. Calibrating the liana crown occupancy index in Amazonian forests. Forest Ecol. Manag. 260: 549-555. 
Wagner, G. 2007. The developmental genetics of homology. Nat. Rev. Genet. 8: 473-479.

Wagner, G. P., J. Mezey \& R. Calabretta. 2005. Natural selection and the origin of modules. Pp. 3349 in W. Callebaut \& D. Rasskin-Gutman (eds.), Modularity: Understanding the Development and Evolution of Natural Complex Systems. MIT Press, Cambridge, Massachussets.

Waites, R., H. R. Selvadurai, I. R. Oliver \& A. Hudson. 1998. The PHANTASTICA gene encodes a MYB transcription factor involved in growth and dorsoventrality of lateral organs in Antirrhinum. Cell 93: 779-789.

Waites, R. \& A. Hudson. 1995. phantastica: a gene required for dorsoventrality of leaves in Antirrhinum majus. Development 121: 2143-2154.

Wiens, J. J. 1999. Polymorphism in systematics and comparative biology. Ann. Rev. Ecol. Syst. 30: $327-$ 362.

Wojciechowski, M. F., M. Lavin \& M. J. Sanderson. 2004. A phylogeny of legumes (Leguminosae) based on analyses of the plastid matK gene resolves many well-supported subclades within the family. Am. J. Bot. 91: 1846-1862.

Zhu, S. D. \& K. F. Cao. 2010. Contrasting cost-benefit strategy between lianas and trees in a tropical seasonal rain forest in southwestern China. Oecologia 163: 591-599. 


\section{Capítulo 2}

Not ALL TENDRILLED LEAVES ARE REGULATED EXCLUSIVELY By LEAFY/FLORICAULA: EXPRession Patterns of STM, LFY/FLO ANd PHAN in Bignonieae (Bignoniaceae, Lamiales)

Finally, it is a highly remarkable fact that a leaf should become metamorphosed into a branched organ which turns from the light, and which can by its extremities either crawl like roots into crevices or seize hold of minute projecting points...

Charles Darwin, 1865 


\section{RESUMo}

Folhas são os órgãos responsáveis pela fotossíntese na maioria das angiospermas. Estes órgãos sofreram significativas modificações funcionais e estruturais ao longo do tempo, e atualmente apresentam uma ampla diversidade de formas, tamanhos e arranjos. Nas famílias Fabaceae e Bignoniaceae, por exemplo, folíolos podem ser modificados em gavinhas, as quais são estruturas filiformes que se enrolam em outras plantas, usando-as como suporte para escalar. Apesar da importância das gavinhas para as plantas escandentes, muito pouco ainda é conhecido sobre a origem, desenvolvimento e estrutura geral das gavinhas em angiospermas. Atualmente, existem dados disponíveis sobre genes que controlam o desenvolvimento de gavinhas foliares apenas para Pisum sativum, limitando nosso conhecimento sobre a biologia das gavinhas em geral. Apesar dos genes KNOX1 controlarem o desenvolvimento foliar da maioria das espécies que possuem folhas compostas, em P. sativum KNOX1 não é expresso nos primórdios foliares. Por outro lado, o gene LEAFY/FLORICAULA (LFY/FLO), um gene de identidade floral, é o principal regulador do desenvolvimento foliar em P. sativum. Estes dados sugerem que o desenvolvimento de folhas que possuem gavinhas em outras espécies também poderia ser regulado por $L F Y / F L O$. Com o objetivo de investigar a estrutura, origem e base genética da formação de gavinhas foliares em Bignonieae (Bignoniaceae), realizamos um estudo detalhado das folhas em três representantes desta tribo que apresentam tipos diferentes de gavinha: Amphilophium buccinatorium (gavinhas multífidas), Dolichandra unguis-cati (gavinhas trífidas), e Bignonia callistegioides (gavinhas simples). Para estas três espécies nós: (1) investigamos a polaridade dos pecíolos, peciólulos e gavinhas através de estudos anatômicos; (2) clonamos os genes STM, PHAN e LFY/FLO através de RT-PCR; e (3) investigamos os padrões de expressão dos genes STM, PHAN e LFY/FLO durante o desenvolvimento das folhas através de hibridização in situ. Nossos resultados demostraram que todas as partes foliares, incluindo as gavinhas, apresentam polaridade ab-adaxial. Além disso, as gavinhas apresentam algumas características típicas de folíolos, corroborando a hipótese de que as gavinhas são folíolos modificados em Bignonieae. Em particular, transcritos dos genes STM e LFY/FLO foram detectados em folhas de Bignonieae em desenvolvimento, evidenciando que em representantes deste grupo folhas com gavinhas se desenvolvem de maneira diferente das folhas de Pisum sativum. Além disso, transcritos do gene PHAN foram detectados no domínio adaxial dos primórdios de gavinha em espécies com gavinhas ramificadas, em um padrão muito similar ao padrão visto durante o desenvolvimento dos folíolos, reforçando as 
evidencias de que gavinhas são folíolos modificados. Por fim, detectamos que PHAN e STM se expressam num padrão temporal e espacialmente coincidente, corroborando estudos prévios em outras plantas que possuem folhas compostas. Em particular, que os genes KNOX1 controlam o desenvolvimentos de folhas compostas na maioria das angiospermas, com a co-expressão de $S T M$ e PHAN estando relacionada com um maior grau de elaboração da lamina foliar. Além disso, os resultados sugerem que PHAN pode ter um papel importante no estabelecimento da polaridade em gavinhas. O possível papel dos genes STM, PHAN e $L F Y / F L O$ no desenvolvimento das folhas de Bignonieae é discutido.

Palavras-chave: Bignonieae, Bignoniaceae, desenvolvimento, expressão gênica, folhas compostas, gavinhas, LEAFY/FLORICAULA, lianas, PHANTASTICA, SHOOTMERISTEMLESS. 
Not all tendrilled leaves are regulated exclusively by $L E A F Y / F L O R I C A U L A$ : expression patterns of $S T M, L F Y / F L O$ and $P H A N$ in Bignonieae (Bignoniaceae, Lamiales)

Mariane Silveira de Sousa-Baena, ${ }^{1,2^{*}}$ Lúcia G. Lohmann, ${ }^{1 *}$ Magdalena Rossi, ${ }^{1}$ and Neelima Roy Sinha ${ }^{2 *}$

${ }^{1}$ Universidade de São Paulo, Instituto de Biociências, Departamento de Botânica, Rua do Matão, 277, CEP 05508-090, São Paulo, SP, Brazil.

${ }^{2}$ Section of Plant Biology, University of California at Davis, 1 Shields Avenue, Davis, CA 95616, USA.

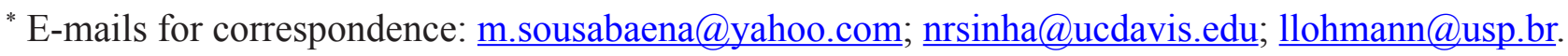

Running title: Expression of STM, PHAN and $L F Y / F L O$ in tendrils

\section{ACKNOWLEDGEMENTS}

We thank Andrew Doust and Cawas Engineer for helpful suggestions in the early stages of this study. This paper is part of the Ph.D. dissertation of M.S., which was supported by fellowships from the Conselho Nacional de Desenvolvimento Científico e Tecnológico (CNPq, Grant 140470/2007-7), and from the Coordenação de Aperfeiçoamento de Pessoal de Nível Superior (CAPES, Grant 4395-08-5), a crossdisciplinary training grant from MORPH (Molecular and Organismic Research in Plant History), and an NSF Developmental Mechanisms award to N.S. (Grant 0641696). 


\begin{abstract}
Leaves are responsible for photosynthesis in the majority of angiosperms. These organs have undergone major functional and structural modifications over time, and currently exist in a wide diversity of forms, sizes, and arrangements. In the Fabaceae and Bignoniaceae, for example, leaflets can be modified into tendrils, which are filiform structures that twine around other plants in search of support for climbing. Despite the importance of tendrils for climbing plants, little is still known about the origin, development and general structure of tendrils in the angiosperms. To date, no data is available on the genes that control leaf development in tendrilled species other than pea (Pisum sativum), limiting our current understanding on the biology of tendrils. Even though $K N O X 1$ genes control leaf development in the majority of compound-leaved angiosperms, in pea, KNOX1 is completely excluded from the leaf primordium; instead LEAFY/FLORICAULA ( $L F Y / F L O)$, a floral identity gene is a major regulator of leaf development in pea. This observation suggests that the development of other tendrilled-leaves might also be regulated by $L F Y / F L O$ as well. In order to gain a better understanding of the structure, origin and genetic basis of leaf tendrils, we conducted a detailed developmental study of leaf tendrils in three representatives of Bignonieae (Bignoniaceae) with different tendril types: Amphilophium buccinatorium (multifid tendrils), Dolichandra unguis-cati (trifid tendrils), and Bignonia callistegioides (simple tendrils). For these three species, we: (1) investigated the ab-adaxial polarity in petioles, petiolules, and tendrils through histological analysis; (2) cloned STM, PHAN and LFY/FLO through RT-PCR; and, (3) investigated the patterns of expression of STM, PHAN and LFY/FLO during leaf development through in situ hybridizations. Our results indicate that all leaf parts, including tendrils, have ab-adaxial polarity. In addition, tendrils present some characteristics that are typical from leaflets, which further corroborate earlier suggestions that tendrils indeed represent modified leaflets in Bignonieae. Furthermore, transcripts of both STM and LFY/FLO were detected in developing leaves, revealing that tendrilled leaves of Bignonieae develop differently from those of pea. Also, $P H A N$ transcripts were detected in the adaxial domain of the tendril primordia in branched-tendrilled species, in a pattern very similar to the pattern seen during leaflet development, reinforcing the evidence that tendrils are modified leaflets. Besides, PHAN and STM expression are temporally and spatially coincident. These results corroborate previous
\end{abstract}


findings for other compound-leaved species, in particular that $K N O X 1$ genes regulate leaf development in the majority of the angiosperms and that coexpression of STM and PHAN relate to a higher degree of leaf blade elaboration. Furthermore, these results suggest an important role for PHAN in the establishment of tendril polarity. The potential role of these three genes in Bignonieae leaf development is discussed.

Key words: ARP genes, Bignonieae, Bignoniaceae, compound leaves, development, gene expression, LEAFY/FLORICAULA, lianas, PHANTASTICA, SHOOTMERISTEMLESS, tendrils. 


\section{INTRODUCTION}

Leaves are responsible for photosynthesis in the majority of angiosperms. These organs have undergone major functional and structural modifications over time, and currently exist in a wide diversity of forms, sizes, and arrangements (Poethig, 1997; Sinha, 1999). For example, leaf parts can turn into tendrils, which are filiform structures that twine around in search of support for climbing (Putz and Holbrook, 1991). Diverse families, such as Fabaceae, Polemoniacae, Ranunculaceae, Papaveraceae, Asteraceae and Bignoniaceae, have developed this strategy, and use their tendrils to reach the canopy and get the necessary light for their development (Darwin, 1875; Kubitzki, 1993, 2004a, 2004b, 2007).

Bignonieae, a large monophyletic tribe within Bignoniaceae, is characterized by the presence of 2-foliolated leaves with the terminal leaflet modified into a tendril (Figs. 1 and 2), among other traits (Lohmann, 2006). The apex of the tendrils of Bignonieae is divided in different ways varying from simple or bifib, to trifid or multifid (several times trifurcated; Lohmann, 2006; Fig. 1). Ancestral character state reconstructions suggest that the ancestral tendril type in Bignonieae was trifid (Lohmann et al., 2011; Sousa-Baena et al., 2011), and that the evolution of the different tendril types involved heterochony (Sousa-Baena et al., 2011). Even though tendril variants have evolved several times in Bignonieae, they are often constant within clades, representing useful generic synapomorphies (Lohmann, 2003). In some species of Bignonieae, however, most individuals lack tendrils and present 3-foliolated leaves, suggesting that the activation/inactivation of genes controlling tendril formation may be achieved easily (Lohmann, 2003).

In general, angiosperm compound leaf development is controlled by class I Knotted-like (KNOXI) genes (Bharathan et al., 2002; Hareven et al., 1996). Four KNOX1 genes are found in Arabidopsis: STM, KNAT1, KNAT2, and KNAT6. (Lincoln et al., 1994; Long et al., 1996; Semiarti et al., 2001; Byrne et al., 2002). In simple leaved species, KNOX1 genes are expressed in the shoot apical meristem (SAM), where they are responsible for maintaining the meristematic state. These genes are then downregulated in leaf founder cells and during leaf development. By contrast, in compound leaved species, KNOX1 is downregulated in $\mathrm{P} 0$, but its expression is reactivated during the formation of leaflets, later in leaf development. This seems to be the most common mechanism employed by angiosperms to keep the 

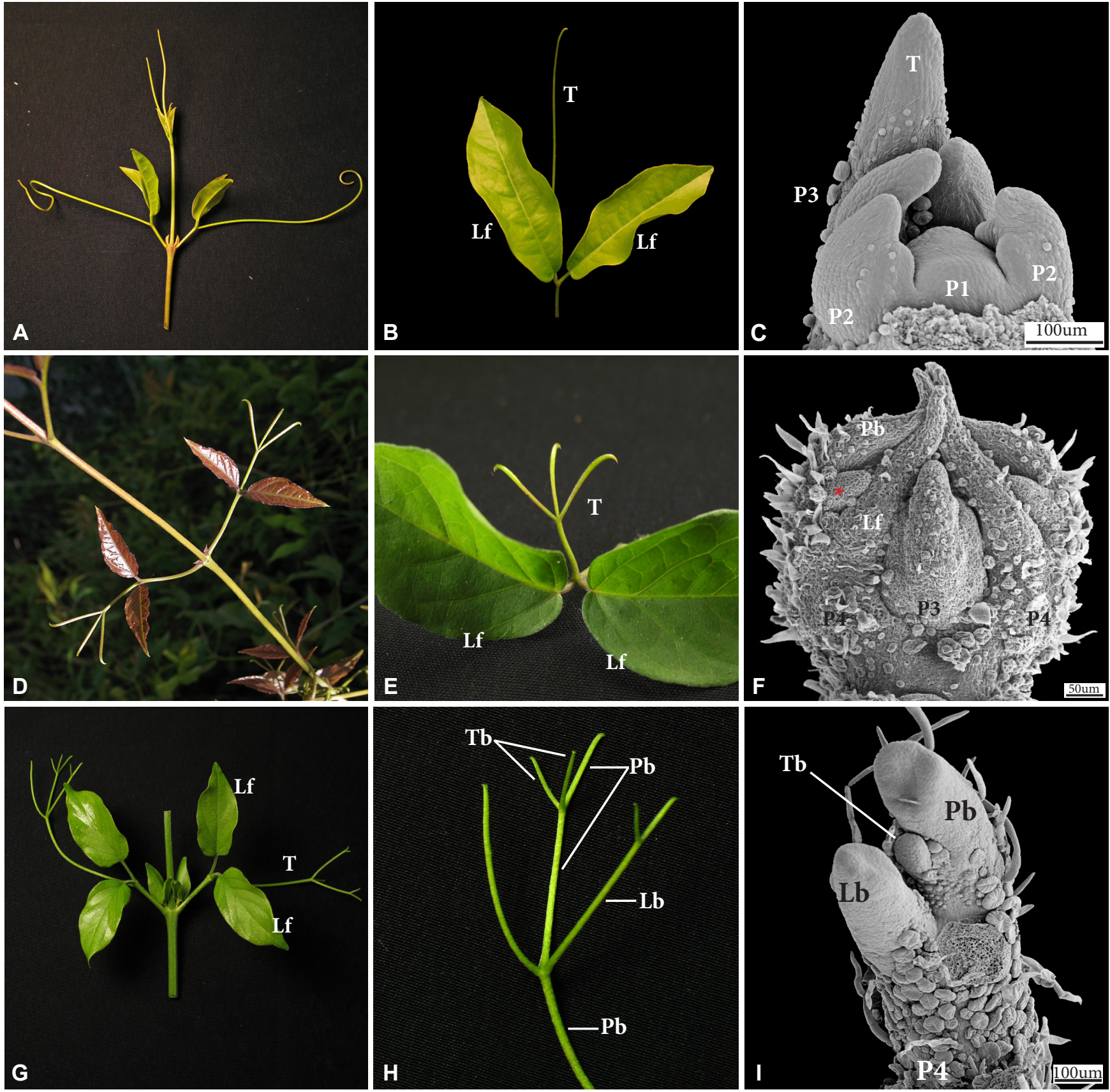

Figure 1. Leaf morphology of Bignonia callistegioides (A-C), Dolichandara unguis-cati(D-F), and Amphilophium buccinatorium (G-I). All three species have opposite phyllotaxy and the terminal leaflet modified into a tendril. C, F and I. Scanning electron microscopy (SEM) micrographs. C. Simple tendril at P3. F. Tendril primary and lateral (red asterisk) branches at P4. I. Detail of the tendril tertiary branches developing at $\mathrm{P} 4$ (leaflets were removed). $\mathrm{Lf}=$ leaflet, $\mathrm{T}=$ tendril, $\mathrm{Pb}=$ tendril primary branch, $\mathrm{Lb}=$ tendril lateral branch, $\mathrm{Tb}=$ tendril tertiary branch (C, D, F, G, H, I from Sousa-Baena et al. 2011). 
undifferentiated state in the leaf margins during secondary morphogenesis, allowing for a higher degree of elaboration of the leaf blade (Bharathan et al., 2002; Hareven et al., 1996; Hay and Tsiantis, 2006).

In pea (Pisum sativum), and other species belonging to the IRLC Clade ("Inverted RepeatLacking Clade") of legumes, another gene is employed in the maintenance of the meristematic state of the primordium marginal tissue (Gourlay et al., 2000; Champagne et al., 2007; Hofer et al., 2009). In these species, LEAFY/FLORICAULA (LFY/FLO) replaces the function of KNOX1 completely and the expression of KNOX1 is not detected in pea primordium at any stage (Hofer et al., 1997). LFY/FLO orthologs are usually known for controlling flower development in a wide range of simple and compound leaved angiosperms (Blazquez et al., 1997; Kramer and Hall, 2005). However, expression of LFY/FLO was also detected in the developing leaves from other angiosperms besides pea, such as Arabidopsis (Blazquez et al., 1997; Hempel et al., 1997), Petunia (Souer et al., 1998), Nicotiana (Kelly et al., 1995), Antirrhinum (Bradley et al., 1996), tomato (Molinero-Rosales et al., 1999), and Eschscholzia californica (Busch and Gleissberg, 2003).

The only alteration in the vegetative morphology of $L F Y / F L O$ (falsiflora) mutants of tomato is the diminished number of intercalary leaflets (Molinero-Rosales et al., 1999), indicating that LFY/FLO has a secondary role in leaf development. In addition, silencing of $L F Y / F L O$ in soybean, a 3-foliolated legume outside the IRCL clade, led to a reduction in the number of leaflets on the second node, indicating a minor role of LFY/FLO in soybean leaf development (Champagne et al., 2007). However, functional studies on other compound-leaved plants are not available, making the exact function of $L F Y / F L O$ orthologs in compound leaf development still uncertain.

Apart from the direct role of $L F Y / F L O$ during leaf development in peas, this gene has also been shown to play important roles in leaf development through interaction with other genes. For instance, during pea leaf development COCHLEATA represses the expression of LEAFY on stipules, while AFILA does the same on proximal leaflet primordia, and AFILA and TENDRIL-LESS repress LEAFY expression in tendril primordia (Gourlay et al., 2000; Hofer et al., 2009; DeMason and Chetty, 2011). Furthermore, KNOX1 has an epistatic interaction with ARP genes (Asymmetric leaves in Arabidopsis, Rough sheath 
2 in maize, and Phantastica in Antirrhinum), inducing cells to enter the differentiation pathway (Koltai and Bird, 2000; Byrne et al., 2000). In simple-leaved plants KNOX1 and ARP genes are expressed in complementary and non-overlapping patterns (Byrne et al., 2000; Timmermans et al., 1999; Tsiantis et al., 1999). However, their expression pattern is temporally and spatially coincident during compound leaf development (Koltai and Bird, 2000; Kim et al., 2003b). Leaf compounding is determined by a balance between the differentiation and indeterminacy programs in the leaf margins. The concerted expression of KNOX1 and ARP during leaf development is thought to have enabled the rise of compound leaves in angiosperms (Kim et al., 2003b). More specifically, the coordinated expression between STM (KNOX1 gene) and ARP genes seems to be mediated by a conserved noncoding regulatory sequence in the 5'upstream region of the STM orthologs, the K-box region (Uchida, et al. 2007).

Besides being involved in the compound leaf primordium differentiation process, ARP genes are also involved in the establishment of the ab-adaxial polarity of leaves in Euasterids (Waites and Hudson, 1995; McHale and Koning, 2004; Kidner and Timmermans, 2007). Adaxial and abaxial leaf surfaces present different tissue types and perform diverse functions, giving an inherent polarity to the leaves. Such polarity is initiated and maintained by multiple regulatory genes (Husbands et al., 2011). In Antirrhinum, tomato and Nicotiana, ARP genes are expressed on the adaxial surface of leaves and their suppression results in leaves with polarity defects (Waites and Hudson, 1995; Kim et al., 2003a; McHale and Koning, 2004). Furthermore, ARP mutants develop needle-like leaves or leaflets that are abaxialized, indicating a role of ARP genes in adaxial domain establishment (Waites and Hudson, 1995; Waites et al., 1998; Kim et al., 2003a; McHale and Koning, 2004; Kidner and Timmermans, 2007). In Pisum sativum, ARP was shown to be involved in the adaxial fate acquisition of leaflets, with its suppression resulting in needle-like leaflets but not in the formation of tendrils (Tattersal et al., 2005).

ARP genes thus seem to play distinct roles during the development of compound leaves controlled by LFY/FLO and KNOX1. In contrast, studies on NO APICAL MERISTEM and CUPSHAPED COTYLEDON (NAM/CUC) genes have shown that other regulatory genes involved in leaf development can interact in a similar way with KNOX1 and LFY/FLO. However, LFY/FLO and KNOX1 are part of different regulatory networks, and the nature of this interaction remains to be clarified (Blein 
et al., 2008). NAM/CUC genes are expressed during the development of organ boundaries, with their misexpression leading to the fusion of organs (Breuil-Broyer et al., 2004; Aida and Tasaka, 2006). In particular, compound leaves regulated by either KNOX1 or LFY/FLO both had fused leaflets or fusion between rachis and leaflets when the expression of $N A M / C U C$ was repressed. Pea leaves (LFY/FLO regulated) also showed fused tendrils when the expression of $N A M / C U C$ was repressed. Furthermore, the number of leaflets was reduced in all species studied, while the number of tendrils was reduced in pea (Blein et al., 2008).

A considerable amount of information on leaf development in model species has been produced over the last two decades (Tsukaya, 2010). However, the only tendrilled-species whose leaf development has already been studied among model species is pea. Pea leaf development is controlled by $L F Y / F L O$ instead of $K N O X 1$ genes as in most other angiosperms, making the results based on pea not generalizable to most other plant groups. Thus, very little is still known about the foliar tendril structure and development in other species outside the Fabaceae. Tendrilled leaves might, however, represent an interesting system to study organ polarity establishment due to the shifts in abaxial-adaxial polarity encountered in tendrilled leaves (i.e., while leaflets develop as normal flattened organs, with marked abaxial-adaxial polarity, tendrils develop as cylindrical structures).

Here, we study the structure of tendrils in Bignonieae and compare it with the general organization of tendrils in pea in order to trace a parallel between the anatomical organization of leaf parts among these especies. In order to test whether the development of leaves of Bignonieae was exclusively controlled by LFY/FLO and not by STM, we isolated orthologs of both of these genes in representatives of Bignonieae with different tendril types (simple, trifid and multifid), and analyzed their expression patterns through in situ hybridizations during development of the compound tendrilled-leaves. In addition, we cloned PHAN and analyzed its expression pattern through RNA in situ hybridizations in order to investigate the establishment of polarity in tendrils. We relate the patterns of expression of PHAN, STM and LFY/ FLO with leaflet and tendril development, and discuss the possible roles of these genes during leaf development in Bignonieae. 


\section{Material AND Methods}

\section{Taxon sampling}

For this study, we selected three species of Bignonieae with different tendril types: Bignonia callistegioides, with simple tendrils, Dolichandra unguis-cati, with trifid tendrils, and Amphilophium buccinatorium, with multifid tendrils (Fig. 1). Samples were collected in different localities at Davis, California (USA), where all these three species are grown as ornamentals. For details and voucher information see Table 1. These samples were used for the histological component of the present study as well as for the genetic portion of the study.

Table 1: Taxa sampled in the anatomical analysis and RNA expression study, followed by the voucher information, and collection localities.

\begin{tabular}{|c|c|c|}
\hline Taxon & Voucher information & Localities \\
\hline Bignonia callistegioides Cham. & Sousa-Baena 3 (DAV) & $\begin{array}{l}\text { United States. California. Davis. UC-Davis } \\
\text { Arboretum Terrace Garden. }\end{array}$ \\
\hline $\begin{array}{l}\text { Amphilophium buccinatorium } \\
\text { (DC.) L.G. Lohmann }\end{array}$ & Sousa-Baena 4 (DAV) & $\begin{array}{l}\text { United States. California. Davis. UC-Davis } \\
\text { campus. }\end{array}$ \\
\hline $\begin{array}{l}\text { Dolichandra unguis-cati (L.) } \\
\text { L.G. Lohmann }\end{array}$ & Sousa-Baena 5 (DAV) & $\begin{array}{l}\text { United States. California. Davis. UC-Davis } \\
\text { campus. Life Sciences Building courtyard. }\end{array}$ \\
\hline
\end{tabular}

\section{Anatomical study}

A detailed histological study was conducted in order to identify the plane of symmetry in the various leaf parts of three selected representatives of Bignonieae (A. buccinatorium, D. unguis-cati, and B. callistegioides). Analyses were conducted in young and mature petioles, petiolules, and tendrils. Fresh samples and embedded materials were used in these analyses, as follows:

Embedded material. Shoot apices were fixed for 16 hours in 4\% paraformaldehyde. Apices were subsequently dehydrated in a graded ascending series of ethanol and gradually embedded in paraplast for the anatomical studies (Garcês \& Sinha, 2009). Embedded specimens were sectioned using a rotary microtome, mounted on slides, and stained with toluidine blue (O'Brien et al., 1964). Sections were 
permanently mounted with "permount" (Fisher Scientific).

Fresh material. Hand sectioned material was cut in water, and then clarified in $50 \%$ bleach for 5 min. The material was subsequently rinsed in water five times and then stained with toluidine blue (O’Brien et al., 1964) for $30 \mathrm{~min}$. Sections were then rinsed in water until the excess of dye had been removed and mounted on $50 \%$ glycerol.

\section{Leaf developmental stages}

In this study, we followed leaf developmental stages that were previously established for Bignonieae (Sousa-Baena et al., 2011). In particular, P1 is defined as an undivided protuberance emerging from the shoot apical meristem, while P2 presents leaflet primordia defined in the flanks of the leaf primordium, with the tendril primordium being evident as the distal terminal part of the leaf primordium. In simpletendrilled species more advanced stages of development can be identified by the degree of epidermal differentiation. In branched-tendrilled species, P3 is marked by the development of the lateral branches of the tendril, and in multifid-tendrilled species, $\mathrm{P} 4$ is defined by the rising of the tertiary branches of the tendril.

\section{Gene cloning}

Total RNA was extracted from shoot apices using the RNeasy Mini Kit (Qiagen, cat. number 74104). A reverse transcription polymerase chain reaction (RT-PCR) using the total RNA was then performed to isolate STM, ARP and LFY/FLO from Bignonia callistegioides (BcSTM, BcPHAN, BcFLO), Dolichandra unguis-cati (DuSTM, DuPHAN, DuFLO), and Amphilophium buccinatorium

Table 2: Primers used in this study.

\begin{tabular}{llll}
\hline Gene & Primer name & Primer sequence & Source \\
\hline \multirow{2}{*}{ STM } & Kbox & 5'CTGACTACCACTANTTTAGGATTTNCTGTAAAAAGNCTGANNNNNNAAGCATAAAACCCGGGAG 3' & Uchida et al. 2007 \\
& DeSTM475(0)R & 5'GCATCTCACAGTAAGCCTCCATGAACTG 3' & Uchida et al. 2007 \\
\hline \multirow{2}{*}{ PHAN } & AmPHAN-F2 & 5'GAAGTTCCAGGACGAACTGCCAAAAGACTTGGTAAGTGGTGGGAAGT3' & This study \\
& AmPHAN-R1 & 5' CTGCTTCTTTTCTGTGCGCCGCCCATGCACGCTGCCCTTC 3' & This study \\
\hline \multirow{2}{*}{ LFY/FLO } & LFY1-F & 5'GTGACGAACCAAGTGTTCAGGTACGC 3' & This study \\
& LFY1-R & 5'GACGAAGCTTGGTGGGGACATACCAG 3' & This study \\
\hline
\end{tabular}


(AbSTM, AbPHAN, AbFLO). Degenerate primers were used to clone STM (Uchida et al., 2007). Primer sequences for ARP and $L F Y / F L O$ were based on sequences from the same genes in Antirrhinum majus. All primers and respective sequences are presented in Table 2. The region cloned for STM has $682 \mathrm{bp}$ and comprises the 5'UTR and part of the coding sequence (CDS) that includes part of the KNOX domain. For $L F Y / F L O$ we cloned a fragment of 286bp that also correspond to part of the CDS, more precisely to a highly conserved portion of the third exon. For ARP we cloned a fragment of $\sim 500 \mathrm{bp}$ that comprises the end of the second MYB repeat, but the major part of the fragment corresponds to the coding sequence downstream the MYB domain.

We used touchdown RT-PCR to clone all the studied genes. The RT-PCR was performed with the following reagents: $2 \mu l$ of cDNA, $3 \mu l$ of dNTPs (Promega, final concentration $=0.2 \mathrm{mM}$ each dNTP), $1 \mu 1$ of forward primer (final concentration $=0.2 \mathrm{mM}$ ), $1 \mu \mathrm{l}$ of reverse primer (final concentration $=0.2 \mathrm{mM}$ ), $5 \mu l$ of PCR reaction buffer (final concentration of $\mathrm{MgCl}_{2}=2 \mathrm{mM}$ ), $0.5 \mu$ of GoTaq ${ }^{\circledR}$ DNA Polymerase (Promega, final concentration $=2,5 \mathrm{u}$ ), and $37 \mu \mathrm{l}$ of distilled water. For $S T M$ and $L F Y / F L O$, reactions included an initial cycle of $5 \mathrm{~min}$ at $94^{\circ} \mathrm{C}$, followed by 10 cycles of $15 \mathrm{sec}$ at $94^{\circ} \mathrm{C}, 20 \mathrm{sec}$ at $54^{\circ} \mathrm{C}$, decreasing $1^{\circ} \mathrm{C}$ in each cycle, and 2 min at $68^{\circ} \mathrm{C}$, followed by 40 cycles of 15 min at $94^{\circ} \mathrm{C}, 20 \mathrm{sec}$ at $52^{\circ} \mathrm{C}$, and $2 \mathrm{~min}$ at $68^{\circ} \mathrm{C}$. with a final 1 min extension at $72^{\circ} \mathrm{C}$. For ARP, reactions included an initial cycle of 5 min at $94^{\circ} \mathrm{C}$, followed by 10 cycles of $15 \mathrm{sec}$ at $94^{\circ} \mathrm{C}, 20 \mathrm{sec}$ at $60^{\circ} \mathrm{C}$, decreasing $1^{\circ} \mathrm{C}$ in each cycle, and $2 \mathrm{~min}$ at $68^{\circ} \mathrm{C}$, followed by 40 cycles of $15 \mathrm{sec}$ at $94^{\circ} \mathrm{C}, 20 \mathrm{sec}$ at $54^{\circ} \mathrm{C}$, and $2 \mathrm{~min}$ at $68^{\circ} \mathrm{C}$, with a final 10 min extension at $72^{\circ} \mathrm{C}$.

\section{Gene orthology}

In order to assess gene orthology of the cloned sequences of STM, ARP and LFY/FLO orthologs obtained for the three species of Bignonieae, we: (1) aligned the obtained sequences with other angiosperm ortholog sequences; and, (2) performed a phylogenetic analysis based on the deduced amino acid alignment.

Sequence analyses. The cloned sequences of STM, PHAN, and LFY/FLO orthologs obtained for three species of Bignonieae (BcSTM, BcPHAN, BcFLO, DuSTM, DuPHAN, DuFLO, AbSTM, AbPHAN, 
Table 3: STM orthologs used to reconstruct the phylogeny of STM, followed by taxonomic information, and GenBank accession number.

\begin{tabular}{|c|c|c|c|c|}
\hline Ortholog & Species & Family & Order & Genbank accession number \\
\hline invaginata & Antirrhinum majus invaginata & Plantaginaceae & Lamiales & AY072735 \\
\hline hirzina & Antirrhinum majus hirzina & Plantaginaceae & Lamiales & AY072736 \\
\hline SrSTM & Streptocarpus rexii & Gesneriaceae & Lamiales & AY 655753 \\
\hline SsSTM & Streptocarpus saxorum & Gesneriaceae & Lamiales & AY 655754 \\
\hline STM & Arabidopsis thaliana & Brassicaceae & Brassicales & U32344 \\
\hline BrSTM & Brassica rapa & Brassicaceae & Brassicales & GU480585 \\
\hline BnSTM & Brassica napus & Brassicaceae & Brassicales & GU480584 \\
\hline ChSTM & Cardamine hirsuta & Brassicaceae & Brassicales & DQ512732 \\
\hline KNAT1 & Arabidopsis thaliana & Brassicaceae & Brassicales & NM_116884 \\
\hline KNAT2 & Arabidopsis thaliana & Brassicaceae & Brassicales & NM_105719 \\
\hline LeT6 & Lycopersicum esculetum & Solanaceae & Solanales & AF000141 \\
\hline TKn1 & Solanum lycopersicum & Solanaceae & Solanales & U32247 \\
\hline POTH1 & Solanum tuberosum & Solanaceae & Solanales & U65648 \\
\hline TobH1 & Nicotiana tabacum & Solanaceae & Solanales & AY169493 \\
\hline $\mathrm{PhSTM}$ & Petunia $x$ hybrida & Solanaceae & Solanales & AY112704 \\
\hline InSTM & Ipomoea nil & Convolvulaceae & Solanales & EU672819 \\
\hline TmSTM & Terniopsis minor & Podostemaceae & Malpighiales & AB512752 \\
\hline WsSTM & Weddellina squamulosa & Podostemaceae & Malpighiales & AB512748 \\
\hline PsSTM & Polypleurum stylosum & Podostemaceae & Malpighiales & AB512746 \\
\hline EeSTM & Euphorbia esula & Euphorbiaceae & Malpighiales & EF636205 \\
\hline $\mathrm{SbH} 1$ & Glicyne max & Fabaceae & Fabales & L13663 \\
\hline PsKn1 & Pisum sativum & Fabaceae & Fabales & AF080104 \\
\hline MtKNOX1 & Medicago truncatula & Fabaceae & Fabales & EF128056 \\
\hline MtKNOX6 & Medicago truncatula & Fabaceae & Fabales & EF128061 \\
\hline OSH1 & Oryza sativa & Poaceae & Poales & D16507 \\
\hline HvKnox3 & Hordeum vulgare & Poaceae & Poales & X83518 \\
\hline rs1 & Zea mays & Poaceae & Poales & NM_001111861 \\
\hline Kn1 & Zea mays & Poaceae & Poales & NM_001111966 \\
\hline AgaveKNOX1 & Agave tequilana & Asparagaceae & Asparagales & GU980050 \\
\hline EgKNOX1 & Elaeis guineensis & Arecaceae & Arecales & DQ890420 \\
\hline KNAT7 & Arabidopsis thaliana & Brassicaceae & Brassicales & AF308451 \\
\hline KNAT3 & Arabidopsis thaliana & Brassicaceae & Brassicales & X92392 \\
\hline
\end{tabular}


Table 4: ARP orthologs used to reconstruct the phylogeny of ARP, followed by taxonomic information, and GenBank accession number.

\begin{tabular}{|c|c|c|c|c|}
\hline Ortholog & Species & Family & Order & Gene bank accession \\
\hline PHAN & Antirrhinum majus & Plantaginaceae & Lamiales & AJ005586 \\
\hline FaPHAN & Fraxinus americana & Oleaceae & Lamiales & AY180136 \\
\hline VcPHAN & Vitex cannabifolia & Lamiaceae & Lamiales & AY180132 \\
\hline NtPHAN & Nicotiana tabacum & Solanaceae & Solanales & AY559043 \\
\hline LePHAN & Lycopersicon esculentum & Solanaceae & Solanales & AF148934 \\
\hline AhPHAN & Acacia hindsii & Fabaceae & Fabales & AY180134 \\
\hline PsPHAN & Pisum sativum & Fabaceae & Fabales & AF299140 \\
\hline MtPHAN & Medicago truncatula & Fabaceae & Fabales & DQ468322 \\
\hline LcPHANa & Lotus corniculatus & Fabaceae & Fabales & AY790244 \\
\hline LcPHANb & Lotus corniculatus & Fabaceae & Fabales & AY790245 \\
\hline GmPHANa & Glycine max & Fabaceae & Fabales & AY790252 \\
\hline GmPHANb & Glycine max & Fabaceae & Fabales & AY790253 \\
\hline AtAS1 & Arabidopsis thaliana & Brassicaceae & Brassicales & NM_129319 \\
\hline ChAS1 & Cardamine hirsuta & Brassicaceae & Brassicales & DQ512733 \\
\hline TmPHAN & Terniopsis minor & Podostemaceae & Malpighiales & AB512754 \\
\hline CdPHAN & Cladopus doianus & Podostemaceae & Malpighiales & AB512745 \\
\hline HjPHAN & Hydrobryum japonicum & Podostemaceae & Malpighiales & AB512742 \\
\hline PaPHAN & Pachira aquatica & Malvaceae & Malvales & AY180135 \\
\hline AfPHAN & Aquilegia formosa & Ranunculaceae & Ranunculales & AY180131 \\
\hline EcPHAN & Eschscholzia californica & Papaveraceae & Ranunculales & AY228766 \\
\hline $\mathrm{ZmRS} 2$ & Zea mays & Poaceae & Poales & AF143447 \\
\hline SmARP-1 & Selaginella moellendorffi & Selaginellaceae & Selaginellales & XM_002962269 \\
\hline SmARP-2 & Selaginella moellendorffi & Selaginellaceae & Selaginellales & XM_002965187 \\
\hline
\end{tabular}


and $A b F L O$ ) were submitted to BLASTn searches at the NCBI website in order to investigate the degree of similarity with other angiosperm sequences deposited in GenBank. The sequences from the three species of Bignonieae selected for the present study (B. callistegioides, D. unguis-cati and A. buccinatorium), sequences from Antirrhinum majus, sequences from other species belonging to Lamiales (Streptocarpus rexii and Streptocarpus saxorum for STM; Fraxinus americana and Vitex cannabifolia for PHAN; and Mimulus guttatus, Solenostemon scutellarioides, Syringa vulgaris and Titanotrichum oldhamii for FLO), and species to be used as outgroups were aligned using ClustalW1.4 (Hall, 1999). In particular, KNAT3 and KNAT7 (two class II Knotted-like genes from Arabidopsis thaliana) were selected as outgroups in the STM phylogeny; NEEDLY (the LFY/FLO ortholog in Pinus radiata) was used as outgroup in the LFY/FLO phylogeny; and Selaginella moellendorffii ARP-1 and ARP-2 were used as outgroups in the ARP phylogeny. The alignment was edited using BioEdit 7.0.5.3 (Hall, 1999). Since not all sequences of the STM genes included the 5'UTR, this region was trimmed from the sequences of representatives of Bignonieae and the alignment was performed only using the partial coding sequence cloned for STM. A complete list of the $S T M, \mathrm{ARP}$ and $L F Y / F L O$ sequences used in the phylogeny reconstruction is presented in Tables 3, 4, and 5, respectively, followed by their accession numbers. More specifically, residues 1 to 154 of STM, 87 to 266 of ARP, and 184 to 278 of $L F Y / F L O$ were selected for the phylogeny estimation.

Phylogenetic analyses. The orthology of the individual sequences of STM, ARP and LFY/FLO of Bignonieae (BcSTM, BcPHAN, BcFLO, DuSTM, DuPHAN, DuFLO, AbSTM, AbPHAN, and AbFLO) was further accessed through phylogeny reconstruction. The individual gene trees were estimated using maximum likelihood assumption and the software MEGA 5.05 (Tamura et al., 2011). The Jones-TaylorThornton model of amino acid change was used for the phylogeny reconstruction. The rate variation among sites was considered uniformly distributed. Gaps and missing data were eliminated only in pairwise sequence comparisons (pairwise deletion option). Tree support was estimated through ML bootstrap, using 1000 replications.

\section{Gene expression}

We investigated the pattern of expression of STM, PHAN, and LFY/FLO in the three representatives 
Table 5: $L F Y / F L O$ orthologs used to reconstruct the phylogeny of $L F Y / F L O$, followed by taxonomic information, and GenBank accession number.

\begin{tabular}{|c|c|c|c|c|}
\hline Ortholog & Species & Family & Order & $\begin{array}{c}\text { Genbank accession } \\
\text { number }\end{array}$ \\
\hline FLORICAULA & Antirrhinum majus & Plantaginaceae & Lamiales & M55525 \\
\hline $\mathrm{MgFLO}$ & Mimulus guttatus & Phyrmaceae & Lamiales & AY524042 \\
\hline SsFLO & Solenostemon scutellarioides & Lamiaceae & Lamiales & EF527822 \\
\hline SvFLO & Syringa vulgaris & Oleaceae & Lamiales & AY524037 \\
\hline GFLO & Titanotrichum oldhamii & Gesneriaceae & Lamiales & AY526319 \\
\hline FALSIFLORA & Lycopersicum esculetum & Solanaceae & Solanales & AF197936 \\
\hline StLFY & Solanum tuberosum & Solanaceae & Solanales & EU371047 \\
\hline NFL1 & Nicotiana tabacum & Solanaceae & Solanales & U15798 \\
\hline HaLFY & Helianthus annus & Asteraceae & Asterales & GU985596 \\
\hline CrLFY & Chenopodium rubrum & Amaranthaceae & Caryophyllales & EU410481 \\
\hline SLFY & Silene coeli-rosa & Caryophyllaceae & Caryophyllales & AJ311804 \\
\hline HbLFY1 & Hevea brasiliensis & Euphorbiaceae & Malpighiales & AY639379 \\
\hline SdLFY & Salix discolor & Salicaceae & Malpighiales & AY230817 \\
\hline PTLF & Populus balsamifera subsp. trichocarpa & Salicaceae & Malpighiales & U93196 \\
\hline BbLFY & Bauhinia bohniana & Fabaceae & Fabales & AY498922 \\
\hline GmLFY1 & Glycine $\max$ & Fabaceae & Fabales & EF198177 \\
\hline GmLFY2 & Glycine $\max$ & Fabaceae & Fabales & EF198178 \\
\hline UNIFOLIOLATA & Pisum sativum & Fabaceae & Fabales & AF010190 \\
\hline PpLFY & Prunus persica & Rosaceae & Rosales & EF175869 \\
\hline FvLFY & Fragaria vesca & Rosaceae & Rosales & FJ532000 \\
\hline CFL & Cucumis sativus & Cucurbitaceae & Cucurbitales & AF059320 \\
\hline EgLFY & Eucalyptus grandis & Myrtaceae & Myrtales & AY640313 \\
\hline CfLFY & Cedrela fissilis & Meliaceae & Sapindales & AY633622 \\
\hline MLFY & Mangifera indica & Anacardiaceae & Sapindales & FJ803362 \\
\hline PFL & Carica papaya & Caricaceae & Brassicales & DQ054794 \\
\hline LEAFY & Arabidopsis thaliana & Brassicaceae & Brassicales & DQ447103 \\
\hline VFL & Vitis vinifera & Vitaceae & Vitales & AF450278 \\
\hline TroLFY & Trochodendron aralioides & Trochodendraceae & Trochodendrales & AF230078 \\
\hline PlaraLFY & Platanus racemosa & Platanaceae & Proteales & AF106842 \\
\hline EcFLO & Eschscholzia californica & Papaveraceae & Ranunculales & AY188789 \\
\hline RFL & Oryza sativa & Poaceae & Poales & AB005620 \\
\hline LILFY & Lilium longiflorum & Liliaceae & Liliales & EF458319 \\
\hline NEEDLY & Pinus radiata & Pinaceae & Coniferales & U76757 \\
\hline
\end{tabular}


of Bignonieae through in situ hybridizations. For that, shoot apical meristems were fixed in $4 \%$ paraformaldehyde for 16 hours, dehydrated in a graded ascending series of ethanol, and gradually embedded in paraplast following the protocol of Garcês \& Sinha (2009). Sections of 9-12um were mounted on Probe-
Table 6: Amount of probe per slide for each gene.

\begin{tabular}{lccc}
\cline { 2 - 4 } Gene & Amphilophium & Bignonia & Dolichandra \\
\hline STM & $700 \mathrm{ng}$ & $700 \mathrm{ng}$ & $800 \mathrm{ng}$ \\
ARP & $700 \mathrm{ng}$ & $400 \mathrm{ng}$ & $800 \mathrm{ng}$ \\
LFY/FLO & $600 \mathrm{ng}$ & $600 \mathrm{ng}$ & $600 \mathrm{ng}$ \\
\hline
\end{tabular}

On-Plus microscope slides (Fisher Scientific, Pittsburg, Pennsylvania, USA), and incubated at $40^{\circ} \mathrm{C}$ overnight. Riboprobes were generated as in Garcês and Sinha (2009). Probes of 682bp, 509bp, and 286bp were used for the STM, ARP and LFY/FLO hybridizations, respectively. Probe hybridization, washing, and immunolocalization was done as in Garcês and Sinha (2009). The hybridization was performed at $53^{\circ} \mathrm{C}$ to $S T M$ and ARP, and at $54^{\circ} \mathrm{C}$ to $L F Y / F L O$. For details on the probe concentration used for each gene in the three species see Table 6. Slide pictures were adjusted for contrast and brightness on Adobe Photoshop CS5. Accession numbers for the othologs cloned in this study are given in the table 7.

Table 7: Accession numbers for the genes cloned in this study.

\begin{tabular}{llll}
\hline Gene & Ortholog & Species & $\begin{array}{c}\text { GenBank accession } \\
\text { number }\end{array}$ \\
\hline STM & AbSTM & Amphilophium buccinatorium & JN182849 \\
& DuSTM & Dolichandra unguis-cati & JN182851 \\
& BcSTM & Bignonia callistegioides & JN182850 \\
\hline PHAN & AbPHAN & Amphilophium buccinatorium & JN182846 \\
& DuPHAN & Dolichandra unguis-cati & JN182848 \\
& BcPHAN & Bignonia callistegioides & JN182847 \\
\hline AFY/FLO & AbFLO & Amphilophium buccinatorium & JN182843 \\
& DuFLO & Dolichandra unguis-cati & JN182845 \\
& BcFLO & Bignonia callistegioides & JN182844 \\
\hline
\end{tabular}

\section{RESULTS}

\section{Anatomical study}

Histological studies elucidated the internal organization of the tissues of young and mature petioles and tendrils, as well as a detailed understanding of the anatomical structure of petiolules in 


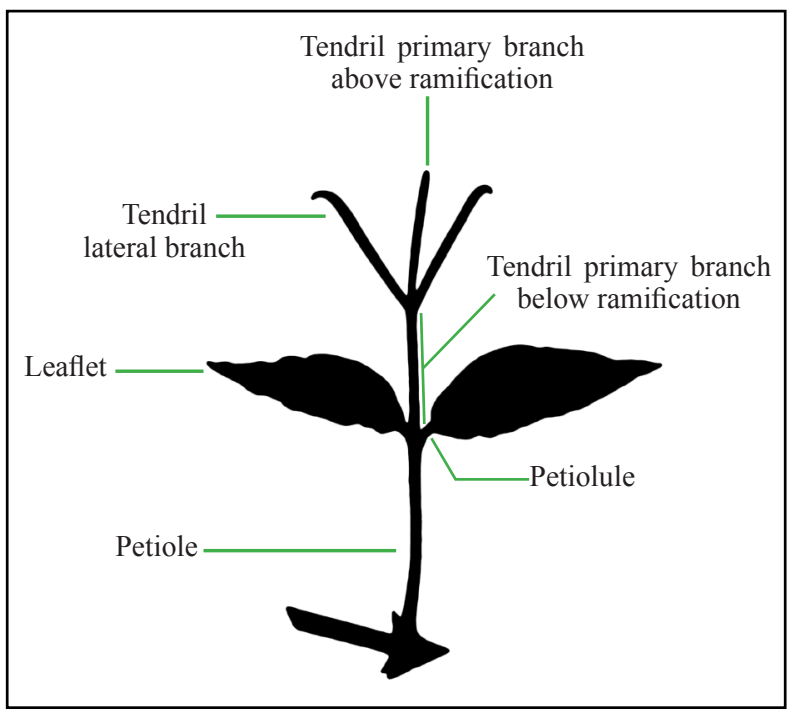

Figure 2. Schematic diagram showing the leaf parts of Bignonieae. the three selected representatives of Bignonieae ( $A$. buccinatorium, D. unguis-cati, and B. callistegioides). Leaf parts of Bignonieae are illustrated in figure 2.

Petiole polarity. The petioles from all studied species present a clear ab-adaxial polarity that can be identified by the shape of the petioles in cross section, and by the arrangement of their median vascular bundle, which is in general an open arc, with the gap facing the adaxial surface of the petiole. In cross-section, young petioles from A. buccinatorium and B. callistegioides are semi-circular, with vascular tissues also arranged in a semi-circle (Figs. 3A, 3B, 3D, 3E, 3G and $3 \mathrm{H})$. However, young petioles of $D$. unguis-cati are triangular, with vascular tissues arranged in an open V-shaped arc (Fig. 3C, 3F and 3I). Mature petioles of A. buccinatorium and B. callistegioides maintain the shape of the young stage in cross section (Figs. 3D-E). However, mature petioles of D. unguis-cati become elliptical with age (Fig. 3F). Because the inter-fascicular cambium produces vascular tissue between the bundles during development, the petiolar vascular system may seem disposed in a ring when the organ is mature. However, the vascular arc does not close completely even in the adults, with gaps being clearly visible in A. buccinatorium and B. callistegioides (Figs. 3G-H). In D. unguis-cati, the adaxial gap seen in the younger stages (Fig. 3C) disappears completely when the petiole becomes mature (Fig. 3F). However, in the mature form it remains possible to identify the region where the gap was present in the young form, and in the mature structure this region is completely filled by xylem fibers and secondary phloem (Fig. 3I). Furthermore, the mature petiole from all species present fiber caps in association with the phloem (Figs. 3D-F).

Petiolule polarity. In cross-section, the shape of the petiolules is similar to that from the petioles in A. buccinatorium and B. callistegioides (Figs. 4A and 4C). In A. buccinatorium however, the petiolule presents a less pronounced secondary growth than the petioles (Fig. 4A). Furthermore, the petiolule lacks a fiber cap associated with the phloem, and gaps remain present in the vasculature of the adaxial region 


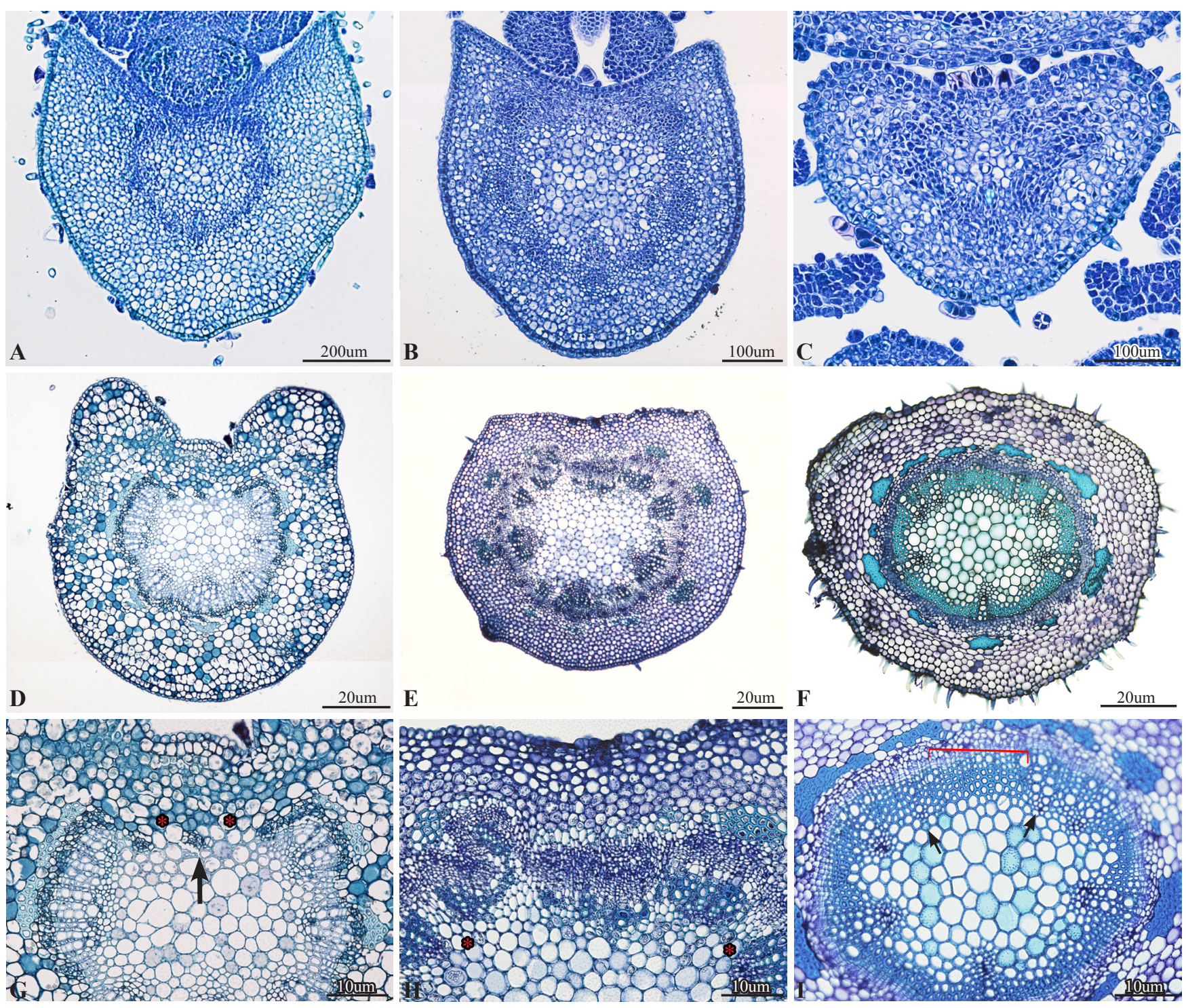

Figure 3. Tranversal sections of the petiole of A. buccinatorium (A, D, G), B. callistegioides (B, E, H), and D. unguis-cati (C, F, I). A-C. Young petioles, showing a lacuna in the vascular system (arrows). D-F. Mature petioles, showing the lacuna filled by vascular tissue derived from the interfascicular cambium (arrows). G-I. Higher magnification of the vascular tissue formed in the lacunas. In A. buccinatotium (G), the lacuna (asterisks) is not completely filled by vascular tissue (arrow). In $B$. callistegioides $(\mathrm{H})$, only a small portion of the lacuna is free of vascular tissue (asterisks), and in D. unguis-cati (I) the whole lacuna (bracket) is delimited by two protoxylem poles (arrows), and filled by vascular tissue.

orthologs from Bignonieae share an overall identity of $69 \%$ with PHANTASTICA, 63\% with NtPHAN and $61 \%$ with $L e P H A N$ at the nucleotide level. The deduced amino acid sequence alignment of all 23 sequences shows some conserved regions, including a highly conserved region that represents the end of the second MYB repeat (Suppl. figure 4).

A phylogenetic analysis of ARP genes was conducted using 23 ARP orthologs in total, including 
A
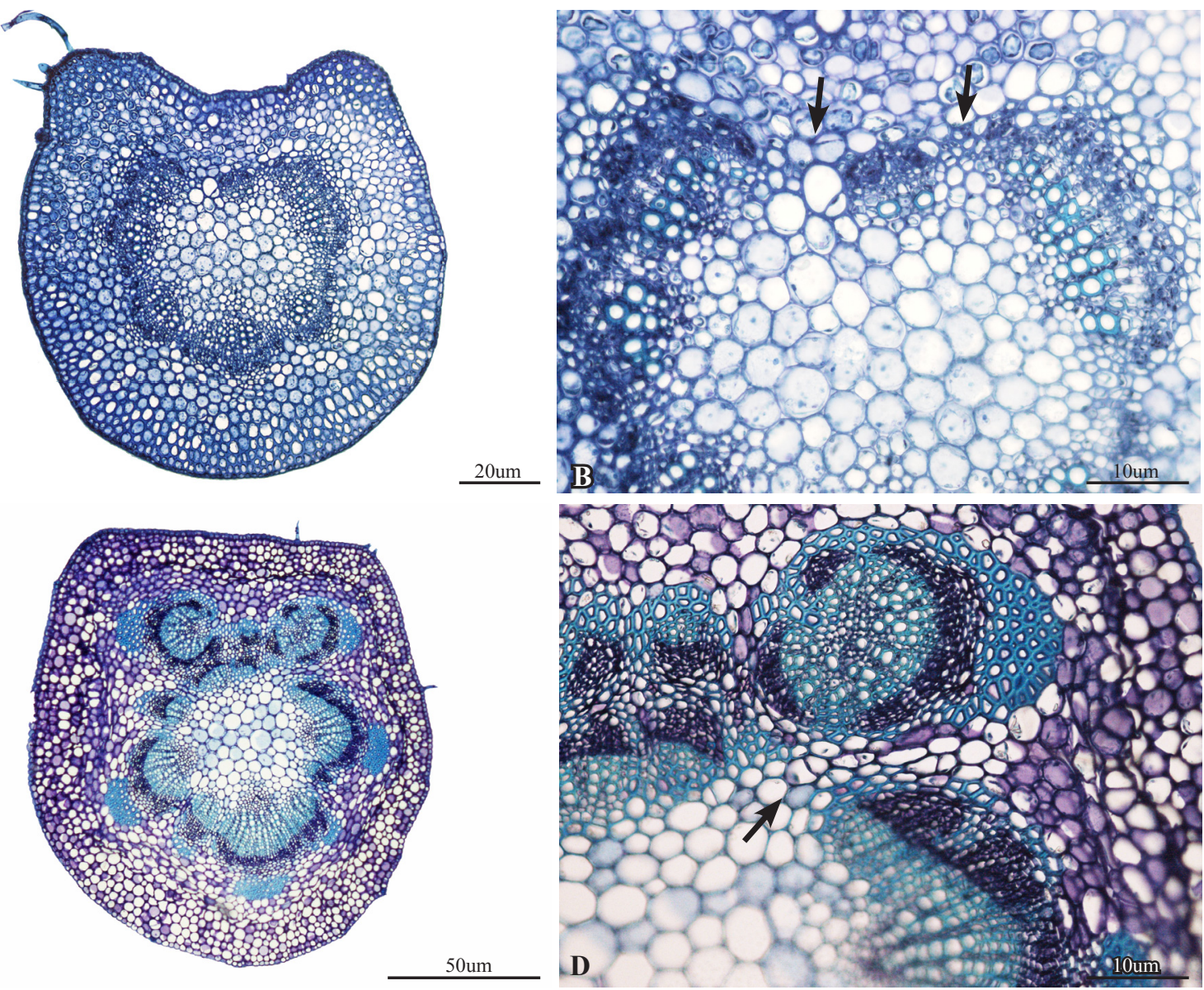

C

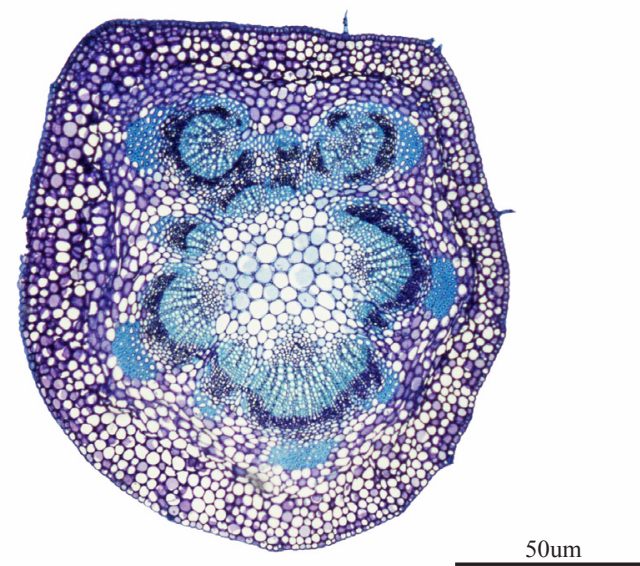

D
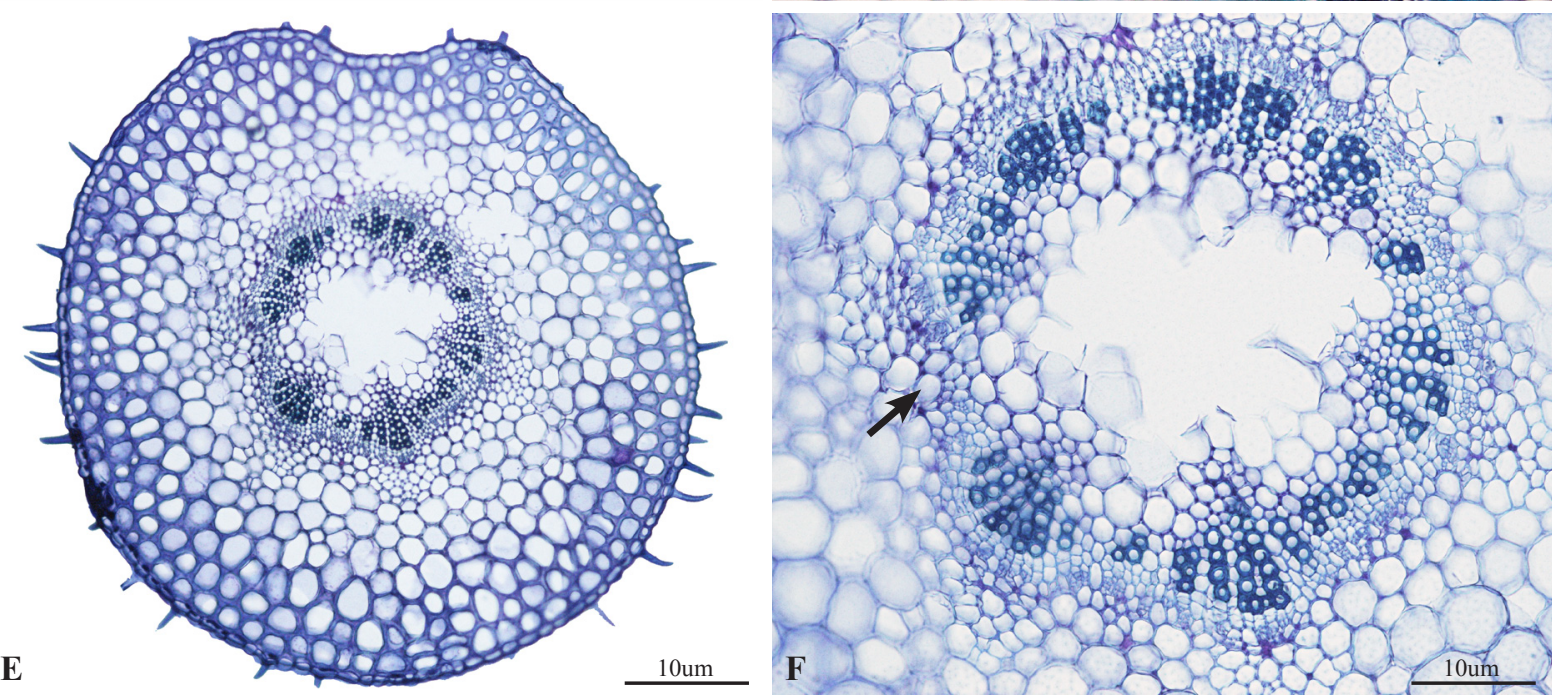

Figure 4. Transversal sections of adult petiolules of A. buccinatorium (A, B), B. callistegioides (C, D), and D. unguis-cati (E, F). A, C, E. Sections showing the shape of petioles in cross section and the disposition of the vascular system. B, D, F. Higher magnification of the vasculature showing lacunas in the vascular system (arrows). 
(Fig. 4B). In B. callistegioides the general organization of the petiolules is similar to that of the petiole, and the major difference in the anatomy of both is the presence of two accessory bundles that developed facing the adaxial side in the petiolules (Fig. 4C). Even though accessory bundles are present in the adaxial region, gaps are still visible in the main vasculature (Fig. 4D). The greatest structural differences between the petiole and petiolule are found in D. unguis-cati. In this species, the petiolule is nearly round in cross section, and presents a vascular secondary growth that is much less pronounced than that of the petioles, as well as lacks a fiber cap associated with the phloem (Fig. 4E). In addition, even though gaps are seen in the vascular system, these are present in a position that does not correspond to the position of gaps in the petiole (Fig. 4F).

Tendril polarity. All three species (A. buccinatorium, B. callistegioides, and D. unguis-cati) have bilaterally symmetrical tendrils that can be identified by a larger vascular bundle that is formed in the abaxial side. In $A$. buccinatorium a flattened leaf-like expansion develops in the tip of the tendrils however, the tendril is cylindrical right below this structure (Fig. 5A). Because of this difference in the structure of the tendril tip, the shape of the tendril is variable (Fig. 5B). In particular, the tendril tip has a semicircular shape in cross section that is similar to that of the leaflet primodium tip (Figs. 5C-D and $5 \mathrm{H}$ ), and gradually becomes roundish towards the proximal region (Figs. 5E-G and 5I). In the young tendrils, a developing vascular bundle is observed throughout the tendril (Figs. 5C-G). This bundle is dislocated to the abaxial surface (Fig. 5G), following the vascular pattern of the petiole (i.e., with the larger vascular bundle facing the abaxial side). The dislocated position of the vascular bundle makes the bilateral symmetry of the tendril evident even when the tendril assumes a round form in cross section (Fig. 5G). In the adults, the tendril develops a vascular arrangement in ring and presents some secondary growth (Fig. 5J).

In D. unguis-cati, the tendril is widely ovate in cross section (Fig. 6A). In the young tendrils, the vascular system is open, with a gap facing the adaxial surface (Fig. 6B). In the mature tendrils, the vascular system is closed due to the activity of the interfascicular cambium during development (Figs. 6C-D). This feature is more accentuated right below the ramification of the tendril tips (Fig. 6D), but is also visible in the lateral tendril branches (Fig. 6C). Mature tendrils present fiber caps associated with the 

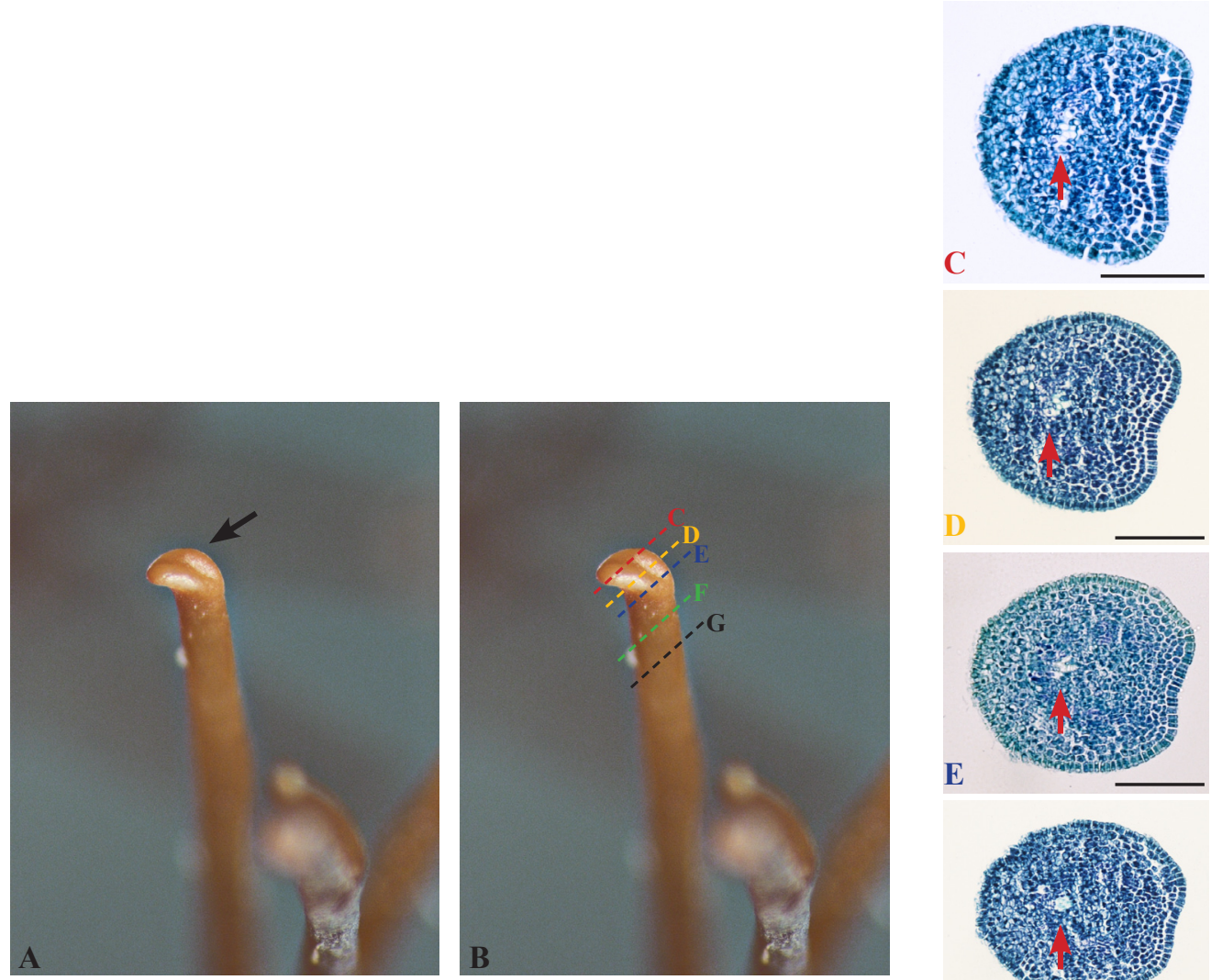

C

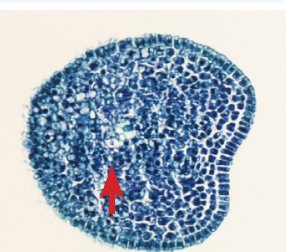

D

$\mathbf{E}$

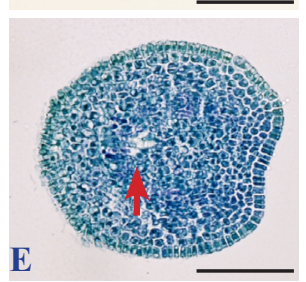

$\mathbf{F}$
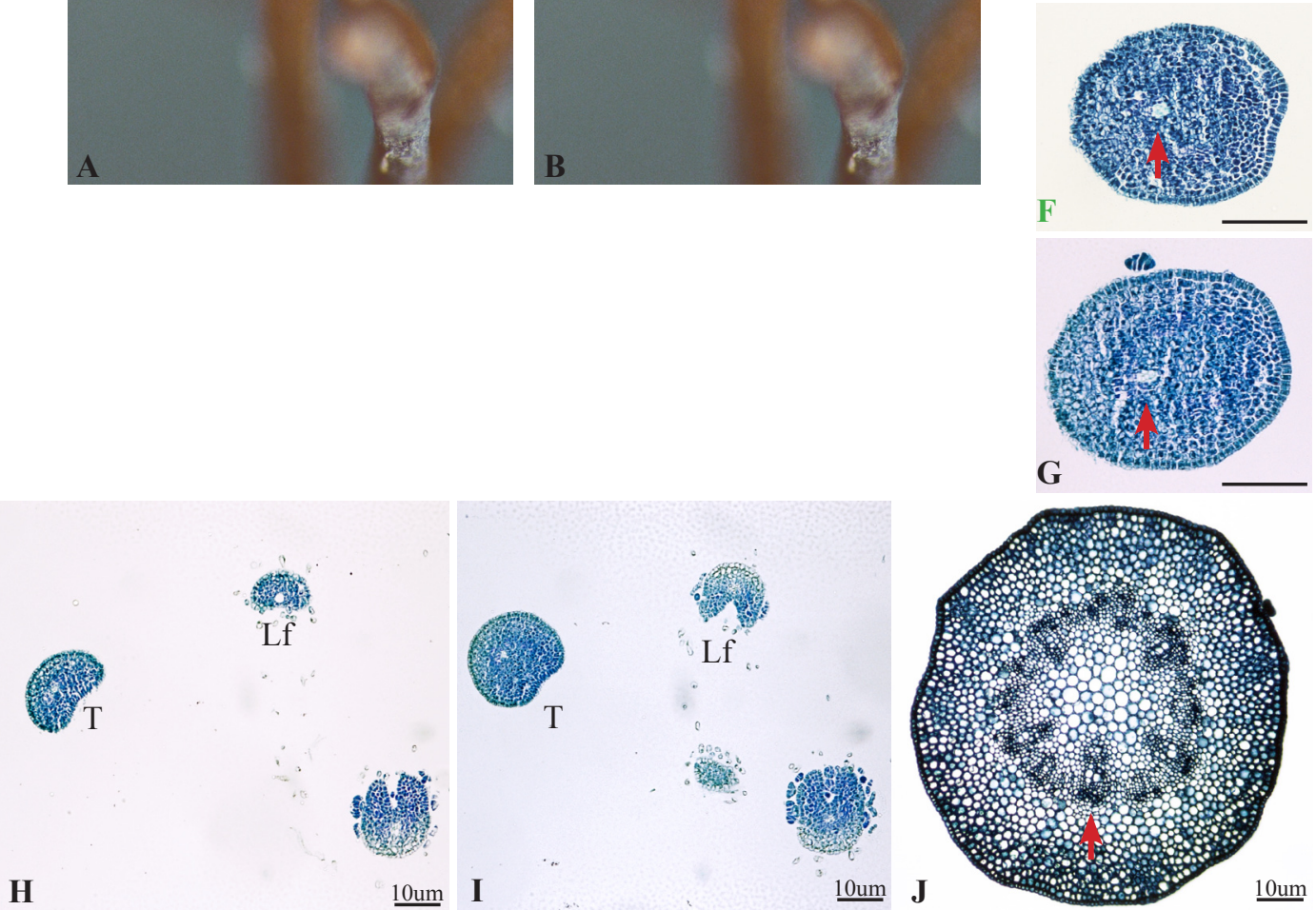

H

$\underline{10 u m}$ I

Figure 5. Transversal sections of tendrils of A. buccinatorium showing tendril shape and the vascular tissue disposition. A. Leaf-like tissue expansion in young tendril tips (arrow). C-G. Serial sections of young tendrils (letters correspond to those indicated in Figure B). Note that the bilateral symmetry can be identified by the larger vascular bundle in the abaxial side of tendrils (arrow). H-I. Serial sections of the tip of young tendrils and leaflet. H. Section illustrating the similar shape of the tendril tip (T) and leaflet (Lf). I. Section in a more proximal region of the tendril illustrating that in this region leaflet starts to acquire its typical form, becoming different from tendrils. J. Cross section of the median region of a mature tendril. Note the larger vascular bundle in the abaxial region (arrow), leading to a bilateral symmetry. Scale bar $=10 \mathrm{um}$. 

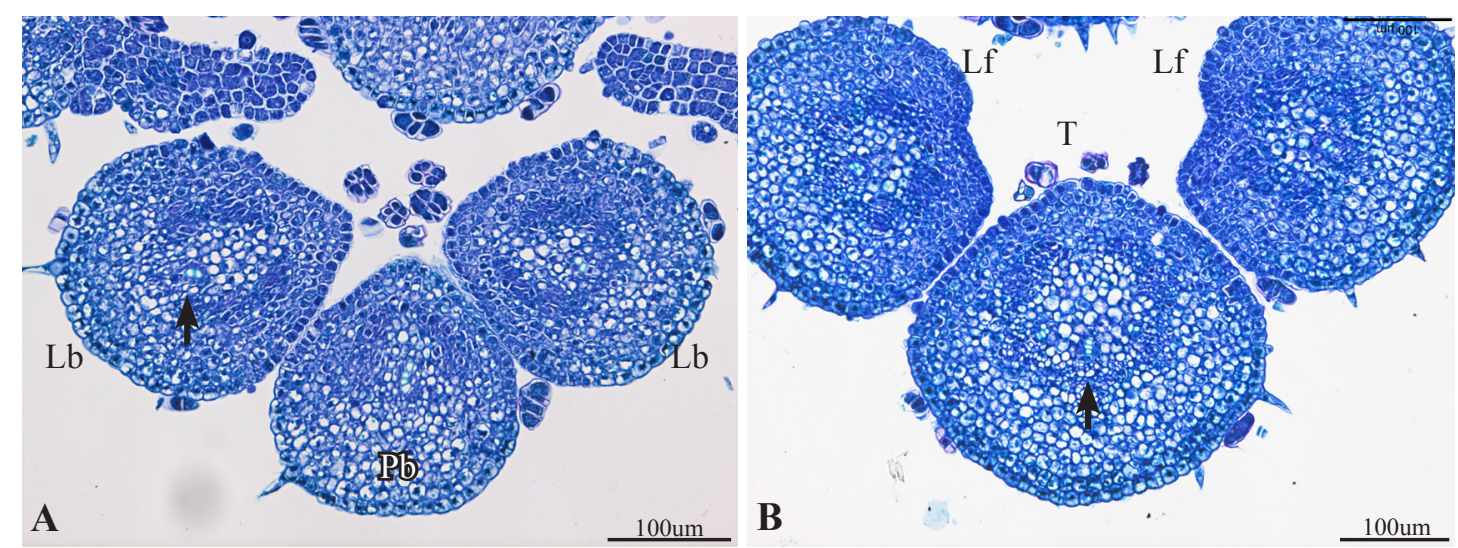

C

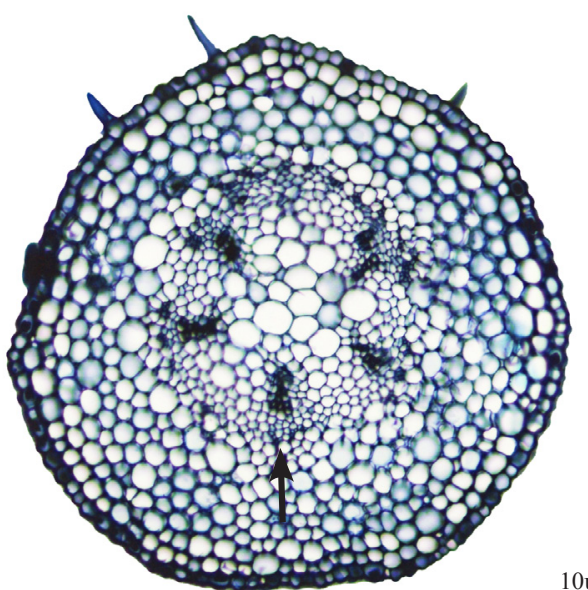

10um

$\mathbf{E}$

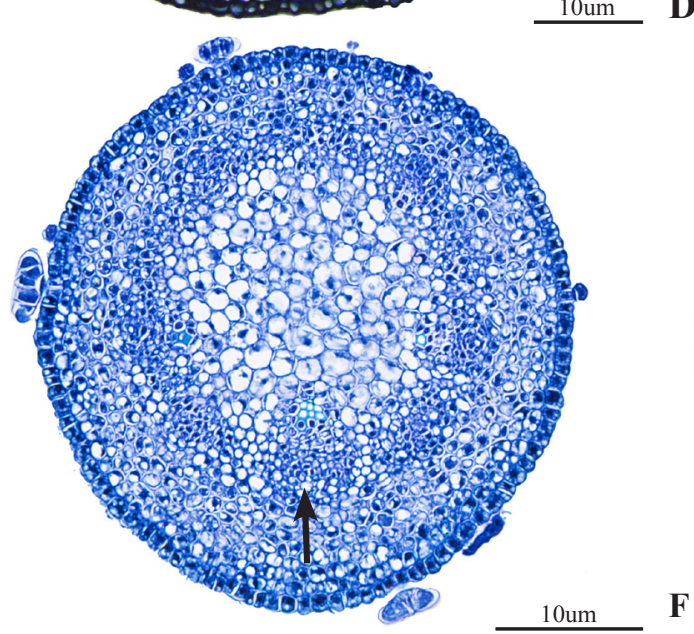

D

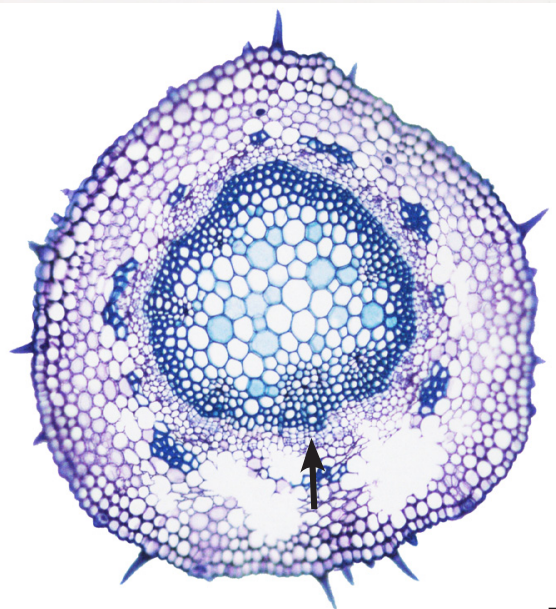

$10 \mathrm{um}$

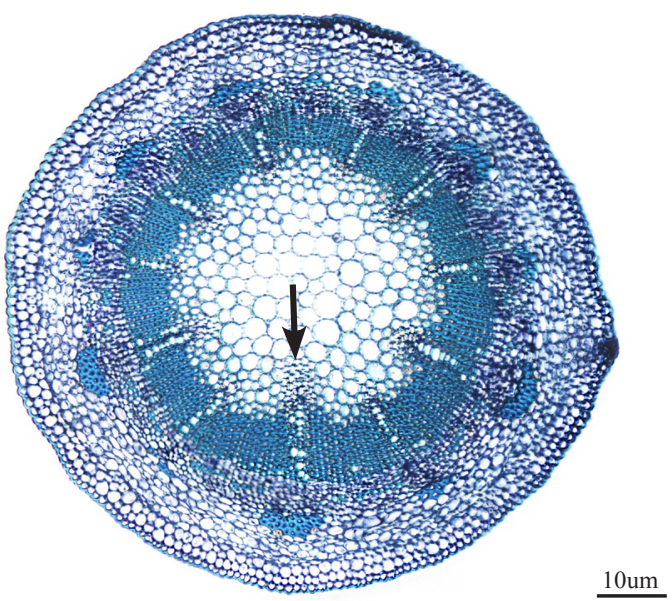

Figure 6. Transversal sections of tendrils of D. unguis-cati (A-D), and B. callistegioides (E-F). A. Sections of a young tendril showing the early stages of the development of the primary and lateral branches. B. Young tendril, section of a primary branch in the region below the ramification. Note that the tendril shape and vasculature arrangement are similar in the regions below and above the ramification in A. C. Mature tendril, cross section of tendril primary branch above the ramification. D. Cross section of a mature tendril showing a primary branch below the ramification point, where the secondary growth is more pronounced when compared with the portions above the ramification. E. Young tendril of $B$. callistegioides in cross section. Arrow indicates the larger vascular bundle in the abaxial side. F. Cross section of a mature tendril of $B$. callistegioides. Arrow indicates the larger vascular bundle in the abaxial side. 
phloem in the region below the ramification (Fig. 6D).

B. callistegioides presents the most radialized anatomy of all three species studied. In younger stages, the tendrils of $B$. callistegioides are circular in cross section, and present a dislocated vascular ring towards the adaxial side that generates a thicker abaxial cortex (Fig. 6E). In adult stage, the secondary growth is pronounced, with the vascular ring becoming centralized (Fig. 6F) and presenting fiber caps associated with the phloem (Fig. 6F).

\section{Gene cloning and orthology}

We cloned STM, ARP and LFY/FLO orthologs for three species of the tribe Bignonieae. The putative protein sequences were aligned with other ortholog sequences from several species of angiosperms in order to assess the degree of similarity among them. We further investigated whether the obtained sequences were genuinely orthologs to genes cloned for Bignonieae through phylogenetic analyses based on the deduced amino acid alignment. STM, PHAN and FLO orthologs cloned from Bignonieae species in this study are being collectively called BigSTM, BigPHAN and BigFLO in the text.

SHOOTMERISTEMLESS. The overall identity of BigSTM with other orthologs sequences at the nucleotide level was: $82 \%$ to $L e T 6,75 \%$ to TobHland $69 \%$ to PhSTM (based on alignment in Suppl. figure 1). The alignment of all 35 putative protein sequences presented a conserved region that corresponds to part of the KNOX domain (Suppl. figure 2).

A phylogenetic analysis was performed using 22 STM orthologs, 8 class I Knotted-like genes, and 2 class II Knotted-like genes. All three Bignonieae orthologs (AbSTM, DuSTM, and BcSTM) formed a monophyletic group that was clustered within the clade that contained Solanaceae orthologs. The clade composed of all BigSTM was sister to LeT6, the Solanum lycopersicum STM ortholog (Fig. 7). Relationships recovered in this tree did not correspond to the known relationships among these taxa (i.e., to the species phylogeny). For example, while BigSTM clustered with the Solanaceae STM, other Lamiales orthologs (SSSTM, SrSTM, hirzina and invaginata) were distantly related (Fig. 7).

ARP. Sequence alignment of BigPHAN and their orthologs (Suppl. figure 3) revealed that PHAN 


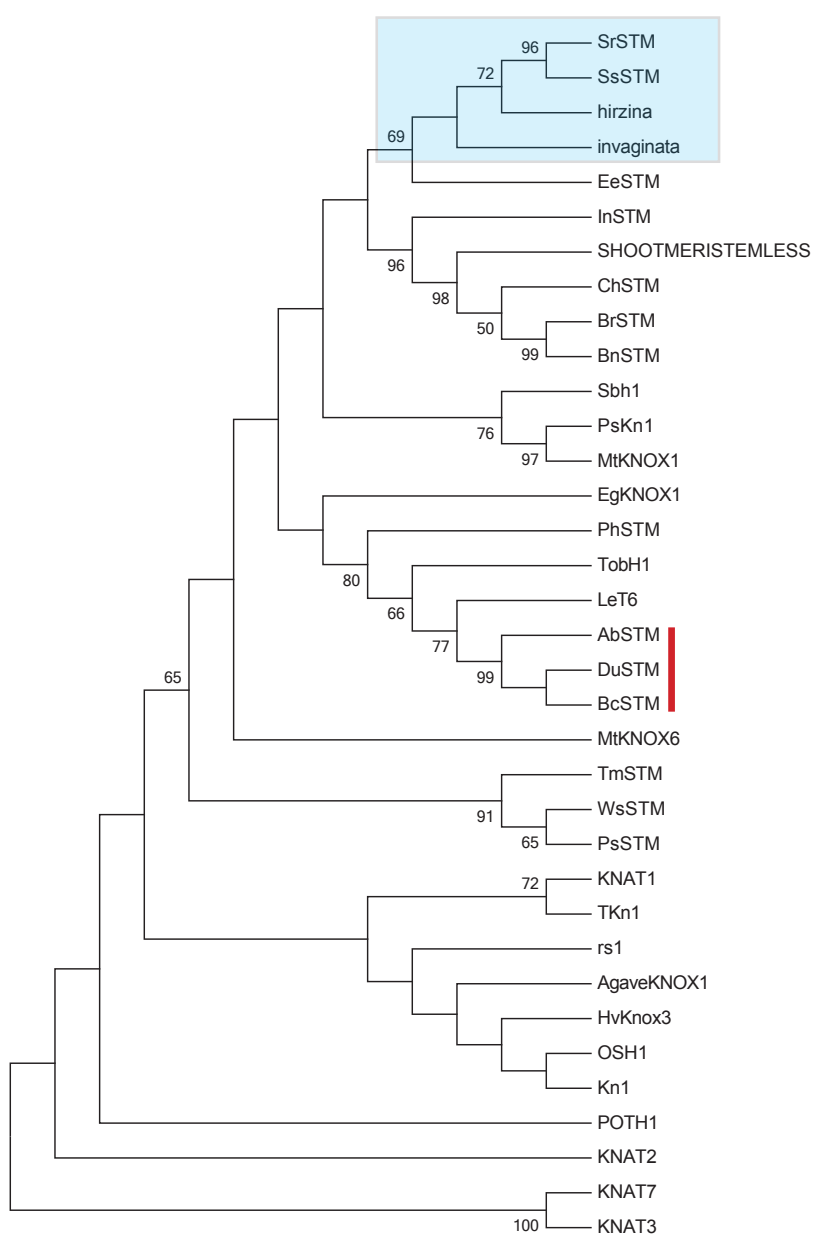

Figure 7. Single optimal maximum likelihood tree resulting from the analysis of the STM cloned for Bignonieae and respective orthologs from other taxa using the JTT model of aminoacid evolution. Red bar indicates STM genes cloned from Bignonieae. Blue box indicates the clade containing other representatives of Lamiales. Bootstrap values are indicated next to nodes with greater than $50 \%$ support. Class II Knotted-like genes from Arabidopsis thaliana were used as outgroups.

the three sequences of Bignonieae ARP genes, 9 sequences from model species (e.g., Arabidopsis thaliana, Antirrhinum majus, Nicotiana tabacum, Lycopersicum esculentum, Pisum sativum, Medicago truncatula, Glycine max, and Zea mays), some non-model species from other orders, and 2 from other Lamiales taxa. All three ARP Bignonieae orthologs (AbPHAN, DuPHAN, and BcPHAN) formed a monophyletic group that was sister to AmPHAN (i.e., PHANTASTICA from Antirrhinum majus), and closely related to $P H A N$ orthologs from the Solanaceae (Fig. 8). However, FaPHAN and VCPHAN, PHAN orthologs from other Lamiales (see Table 3) were more closely related PaPHAN, an ortholog from Paquira aquatica (Malvaceae). These three orthologs formed a monophyletic group that was distantly related to the BigPHAN clade. Overall, relationships recovered in this tree did not correspond to the known relationships among these taxa (i.e., to the species phylogeny).

LEAFY/FLORICAULA. Nucleotide alignment of the three BigFLO sequences with 33 ortholog sequences (Suppl. figure 5) revealed that $L F Y / F L O$ orthologs from Bignonieae share an overall identify of $86.5 \%$ with SSFLO (Solenostemon scutellarioides FLO ortholog), and 84.7\% with FLORICAULA, and $82.5 \%$ with NFL1.

A phylogenetic analysis of $L F Y / F L O$ was conducted using $33 L F Y / F L O$ orthologs in total, including the three sequences of Bignonieae FLO genes, 10 sequences from model species (e.g., Arabidopsis 


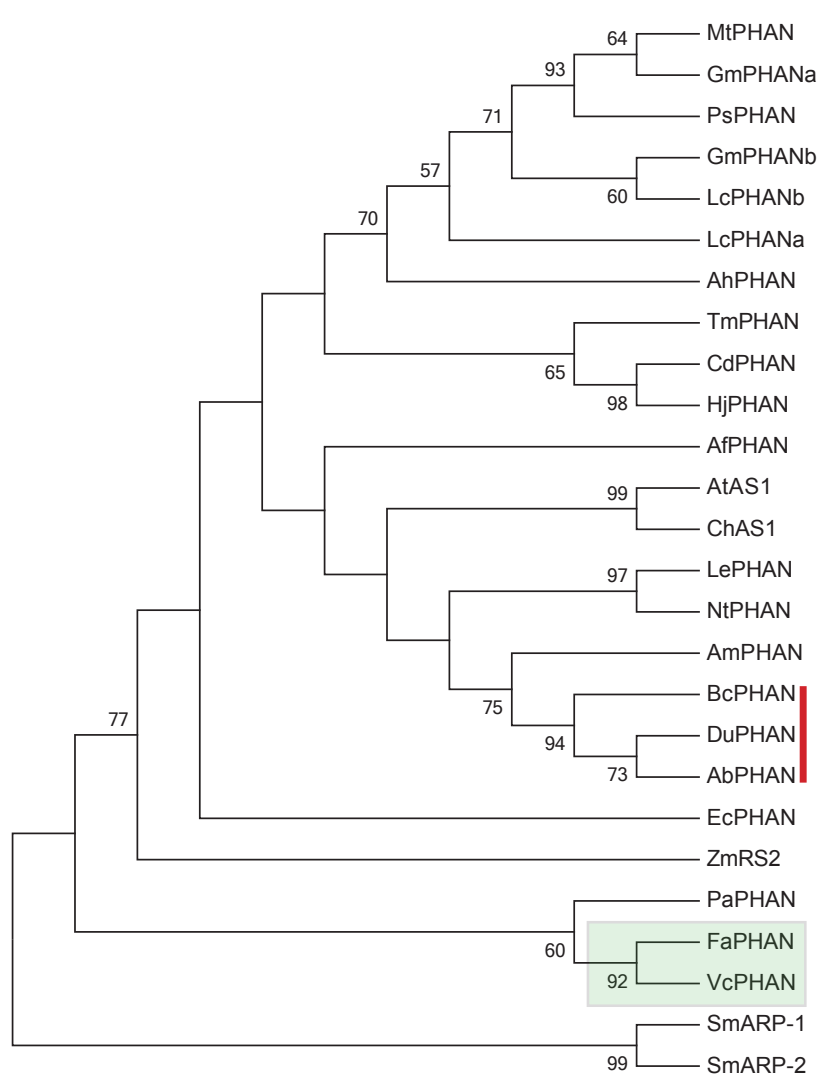

Figure 8. Single optimal maximum likelihood tree resulting from the analysis of the ARP genes cloned for Bignonieae and respective orthologs from other taxa using the JTT model of aminoacid evolution. Red bar indicates Bignonieae ARP genes. Green box indicates other Lamiales species used in the analysis. The numbers beside the branches represent bootstrap values $(>50 \%)$ based on 1000 replications. Selaginella ARP genes were used as outgroups. thaliana, Antirrhinum majus, Nicotiana tabacum, Solanum tuberosum, Lycopersicum esculentum, Pisum sativum, Glycine max, Populus balsamifera and Oriza sativa), some non-model species from other orders, and 4 from other Lamiales taxa.

The alignment of all orthologs showed that the third exon is highly conserved among these species (Suppl. figure 6). The phylogenetic analysis based on this alignment showed DuFLO, $A b F L O$ and $B c F L O$ formed a monophyletic group, sister to FLORICAULA from Antirrhinum majus (Fig. 9). This clade was nested within a clade that included species of Lamiales exclusively. Overall, relationships recovered in this tree did not correspond to the known relationships among these taxa (i.e., to the species phylogeny). Furthremore, very few branches presented bootstrap support larger than $50 \%$.

\section{Gene expression}

SHOTMERISTEMLESS. Expression of STM was detected in the shoot apical meristem (SAM), in the developing leaf primordia, and in the axillary buds of the three species analyzed, A. buccinatorium, B. callistegioides, and D. unguis-cati (Figs. 10A, 11A, and 12A). All species have opposite leaves, which allowed us to identify a lack of expression of STM in the middle of the SAM (P0), in the longitudinal sections that passed through the peripheral portions of the stem (Figs. 10E-F). On the other hand, sections passing through the stem midplane showed expression of STM in all other regions of the SAM (Figs. 


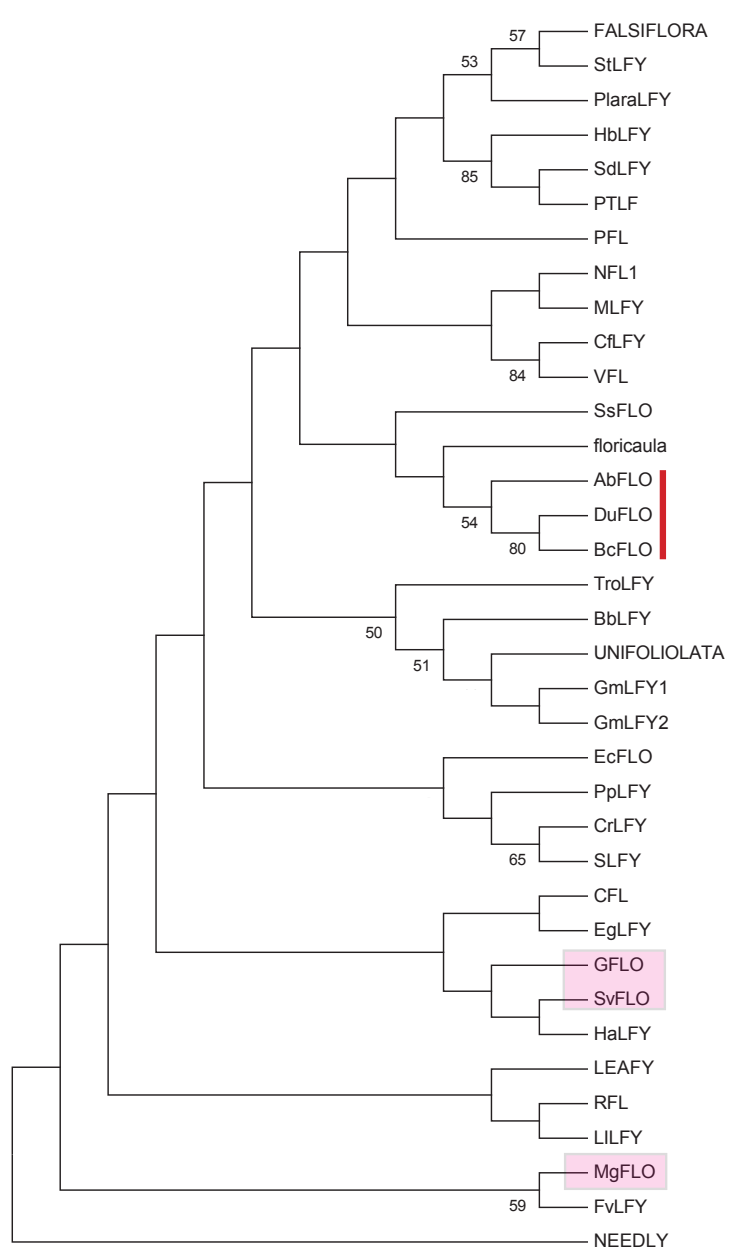

Figure 9. Single optimal maximum likelihood tree resulting from the analysis of the FLO cloned for Bignonieae and respective orthologs from other taxa using the JTT model of aminoacid evolution. Red bar indicates FLO genes cloned from Bignonieae. Pink box points out other Lamiales species used in the phylogeny. Bootstrap values are indicated next to nodes with greater than $50 \%$ support. Pinus radiata $L F Y$ ortholog (NEEDLY) was used as external group.
11B and 12B). High levels of expression of STM were detected in the leaflet primordia of all species (Figs. 10BD, 11C and 12D), with STM being expressed through the whole primordia during the earlier stages of leaf development (Fig. 12E). However, STM transcripts were detected in the boundary between adaxial and abaxial leaf surfaces and in the midrib vasculature in later stages of development (P3 and P4) (Figs. 10D, 11F and 12D).

In the two species with branched tendrils, $A$. buccinatorium (multifid tendrils) and D. unguis-cati (trifid tendrils), high levels of expression of STM were detected in the primary branch tips, in the region where the tendril lateral branches were developing (Figs. 10B and 11C-D). In A. buccinatorium, STM mRNA was detected in the central vascular bundle of the primary branch, in the adaxial region where tendril tertiary branches were developing, and also in the boundary between the abaxial and adaxial domains at late P3 (Fig. 10D). This pattern seems to mimic the pattern of expression found in leaflet primordia. STM expression was also detected in the adaxial domain of the lateral branches of tendrils (Fig. 10D). In B. callistegioides, a simple tendrilled species, STM was highly expressed in leaflet primordia and weakly expressed in tendril primordia (Figs. 12A-B). In tendrils, STM expression was detected in the vasculature and in the adaxial domain at early stages of development. STM was also slightly expressed in the vasculature at P4 (Fig. 12D). Moreover, STM mRNA was also detected in the developing blade of young leaves, where leaf tissues are still not differentiated. Expression of STM was uniform through the lamina in D. unguis-cati and B. callistegioides (Figs. 11E-F 

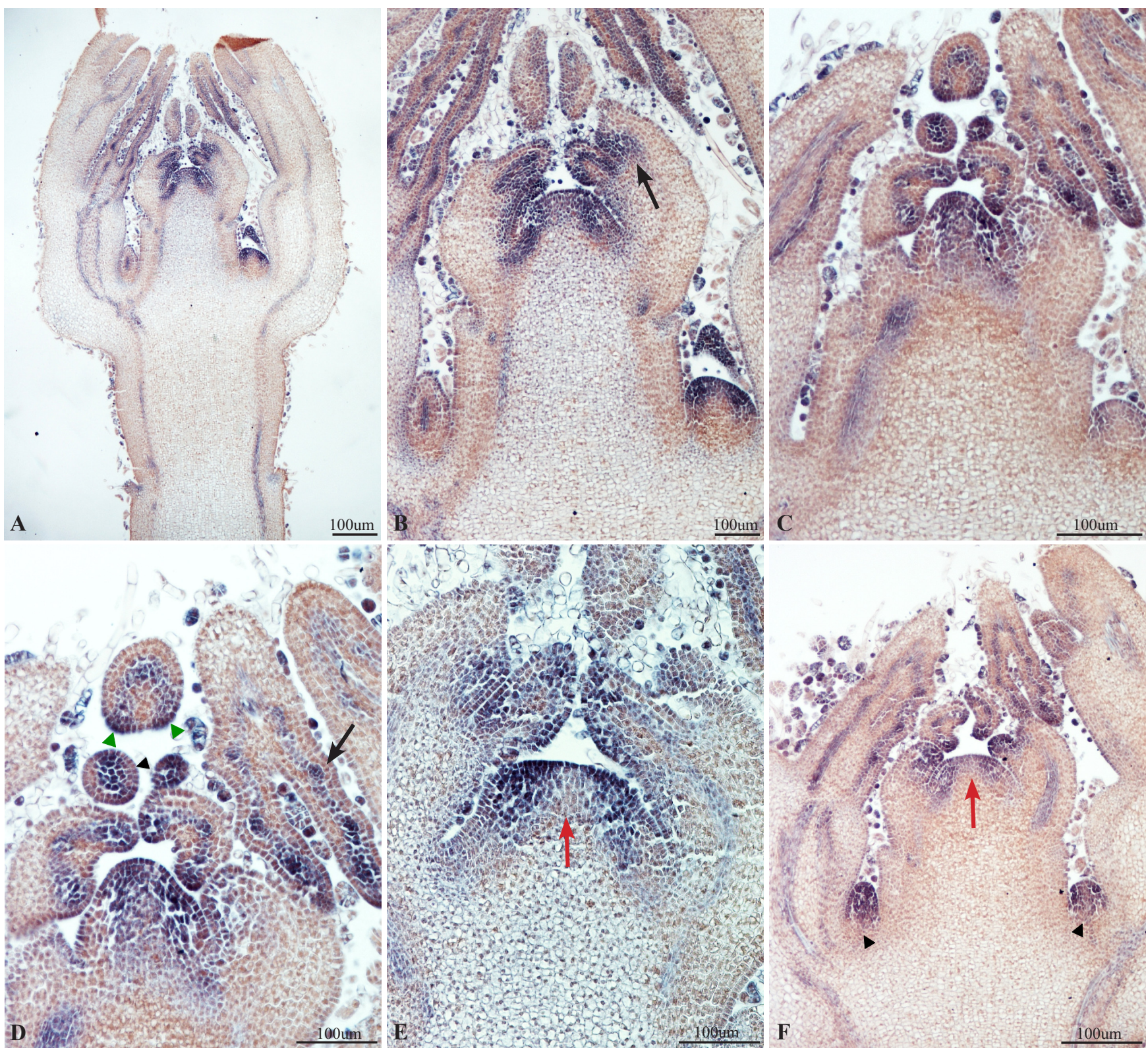

Figure 10. In situ hybridizations of AbSTM in shoot apices of A. buccinatorium. A. Expression of STM in the shoot apical meristem (SAM), in the tendrils, in the leaflet primordia, in the axillary buds and, in the older leaf primordium. B. Expression of STM in higher magnification illustrating that the expression is confined to the adaxial region of the tendril primordium (arrow). C. Expression of STM in the primary and lateral branches of the tendril. D. Higher magnification showing the expression of STM in the adaxial side of the lateral branches of the tendril (black arrowhead), in the region where the tertiary branches are being formed in the primary branch (green arrowhead), in the vasculature, in the boundary between the abaxial and adaxial domains, and in the lateral veins of older primordia (arrow). E. Detail showing the lack of STM expression in the center of the SAM (red arrow), where P0 is developing. F. Strong expression of STM in the axillary buds (arrowheads). 
and 12C) but, were stronger in the lateral veins of $A$. buccinatorium (Figs. 10C-D).

PHANTASTICA. PHAN transcripts were detected in the SAM, leaf primordia and axillary buds of all studied species (Figs. 13A, 16A and 17A). However, the patterns of expression varied among species, as described below.

In $A$. buccinatorium, a species with multifid tendrils, no $A b P H A N$ mRNA was detected in the center and flanks of the SAM at the more peripheral sections of the shoot apex (Fig. 13B). On the other hand, $A b P H A N$ transcripts were detected in the whole SAM in sections passing through the midplane of the stem (Fig. 13A). AbPHAN was strongly expressed in the tip of tendrils confined to the adaxial region, at P1 (Figs. 13C-D). Furthermore, expression of $A b P H A N$ was also detected in the vasculature of the leaf primordia (Fig. 13C). Serial sections of $\mathrm{P} 3$ showed that $A b P H A N$ is also expressed in the midrib vasculature of the leaflet primordia, as well as in the boundary between the abaxial and adaxial domains (Figs. 14A and D). PHAN transcripts were also detected in the adaxial region of the tendril tip (Fig. 14A and D). Sections in the region where tendril lateral branches were developing showed that $A b P H A N$ is strongly expressed in the lateral branches primordia (Figs. 14B and 14E). Furthermore, expression of AbPHAN was also found in the developing vasculature of tendril lateral branches primordia. However, expression of $A b P H A N$ was weaker in the tendril region below the insertion of the lateral branches, and was confined to a smaller domain of the adaxial region (Figs. 14C and 14F). Leaf serial sections at the fourth stage of development revealed that $A b P H A N$ is expressed in the adaxial side of the tip of the lateral branches of tendrils as well (Figs. 15A-B). However, the expression pattern of $A b P H A N$ changes in the median region of the lateral branches, and it is identified in the boundary between the adaxial and abaxial domains, as well as in the midrib vasculature (Fig. 15D). In tendril region in which new branches are not being formed, the expression of $A b P H A N$ is confined to the developing vasculature (Figs. 15C-E). A slight expression of $A b P H A N$ was also detected in the developing vasculature of the petiole (Fig. 15F). In older primordial $A b P H A N$ was detected in the developing lamina (Figs. 13A and 14A).

In D. unguis-cati, a species with trifid tendrils, strong expression of DuPHAN was detected in the whole SAM, including the flanks where new leaves were developing (Figs. 16A-B). In addition, DuPHAN transcripts were detected in the leaf primordia where lateral branches were being formed (Fig. 

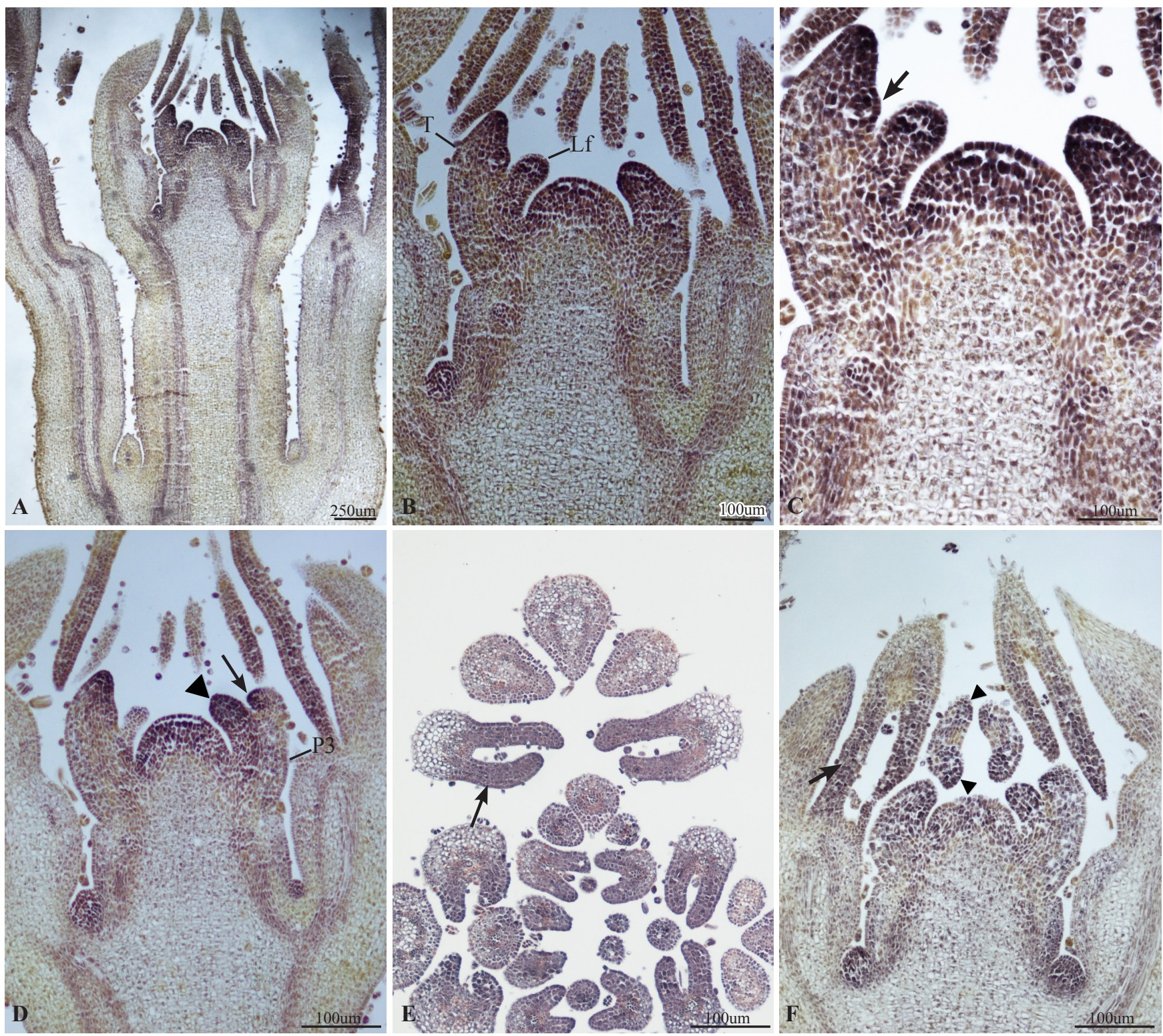

Figure 11. In situ hybridizations of DuSTM in shoot apices of D. unguis-cati. A. DuSTM transcripts were detected in the SAM, in the leaf primordia, and in the axillary buds. B. DuSTM is strongly expressed in tendril and leaflet primordium tips. C. Accumulation of DuSTM in the developing lateral branches of the tendril (arrow). D. Expression of DuSTM at early P3 in the entire leaflet primordium (arrowhead), and in the developing lateral branches of tendrils (arrow). E. Expression of DuSTM in the developing lamina of older primordia (arrow). F. DuSTM is expressed during lamina development in the older leaflet primordia (arrow and arrowheads).

16B-C) and where leaflets were developing (Fig. 16D). In P4, DuPHAN transcripts accumulated in the adaxial side of leaflets (Figs. 16E-F). In older primordia, DuPHAN was expressed in the developing lamina (Figs. 16B).

In $B$. callistegioides, a species with simple tendrils, expression of $B c P H A N$ was detected throughout 

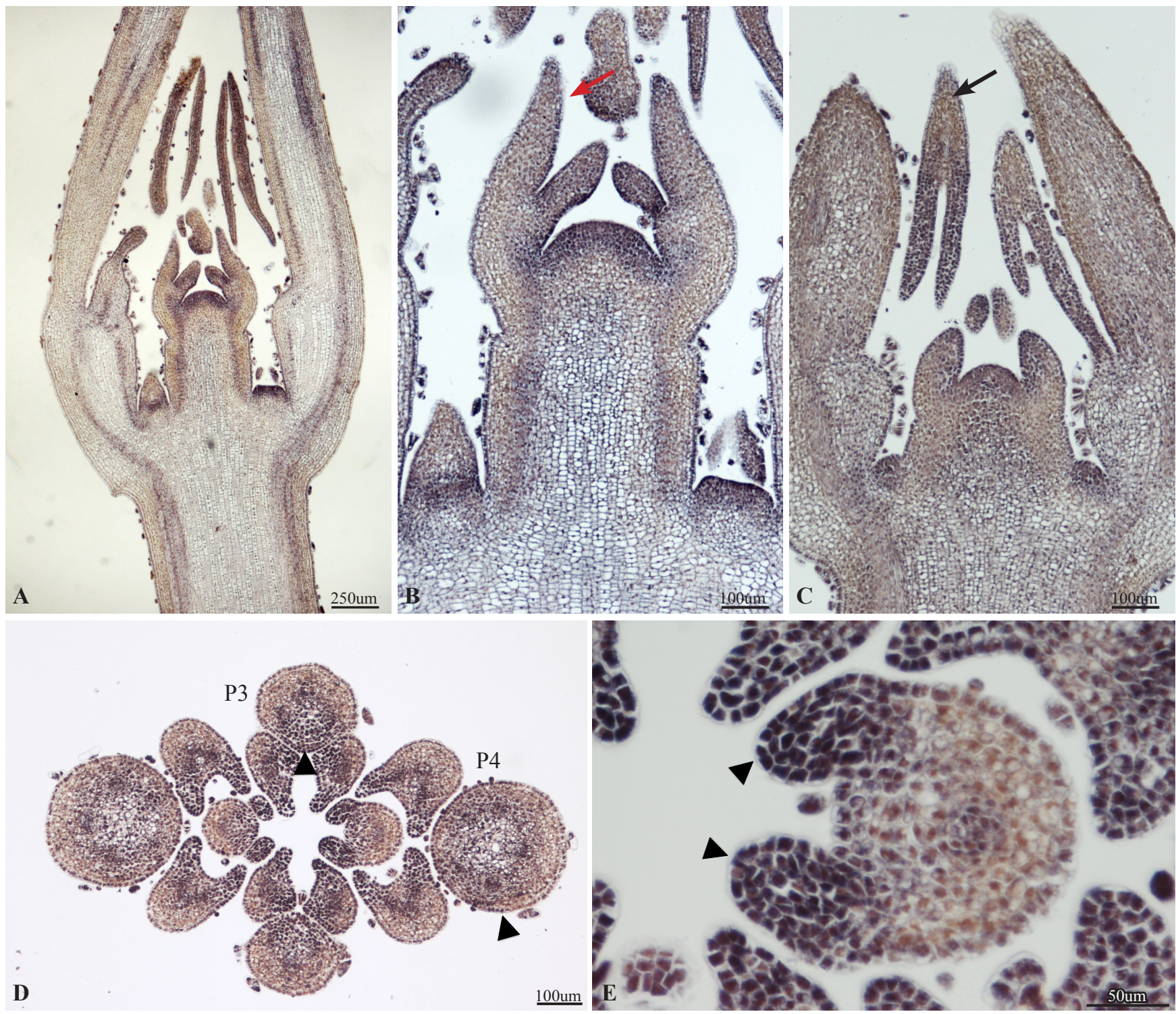

Figure 12. In situ hybridizations of BcSTM in shoot apices of B. callistegioides. A. Expression of BcSTM in the SAM, in the leaf primordia, and in the axillary buds. B. Tendril primary branch showing a lack of expression of STM (arrow) in P2. C. Older leaf primordium showing the expression of BcSTM throughout the developing lamina (arrow). D. Low concentration of $B c S T M$ trancripts in the adaxial region of the tendril (arrowhead) in P3, and in a tendril at P4. E. Strong expression of BcSTM during leaflet development in P2 (arrowheads).

the leaflet primordia, as well as in the tendril tip at P2 stage (Figs. 17A-B). At later developmental stages, expression of BCPHAN was concentrated in the adaxial region of the leaflet primordia and in its midrib vasculature (Figs. 17C-D). In addition, expression of BcPHAN was detected throughout the tendril tip and median region, instead of being confined to the adaxial side of the tendril tip like in the other species (Figs. 17C-E). 
FLORICAULA. FLO transcripts were detected in the SAM, in the leaf primordia, and in the axillary buds of all three species studied (Figs. 18A, 20A and 22A). In A. buccinatorium, AbFLO mRNA accumulates at the tip of the leaf primodia, especially in the adaxial side of the primordia (Fig. 18B). At P2 stage, AbFLO transcripts were also detected in the leaflet primordia, especially in the boundary between abaxial and adaxial domains, and in the midrib vasculature (Fig. 18B). In addition, $A b F L O$ was shown to be strongly expressed in the lateral buds, and in the vascular trace of the prophylls (Fig. 18C). Transverse serial sections from the shoot apex of $A$. buccinatorium including the primordia from P1 to P3 revealed that $A b F L O$ is weakly expressed in the leaflets, and tendril tip at P3 (Fig. 19A). As sections progress downwards, a more visible expression of $A b F L O$ is detected in the adaxial side of leaflets and tendrils. In this region, $A b F L O$ accumulates in the vasculature, as well as in the boundary between the abaxial and adaxial domains of tendrils, presenting an expanded expression domain in the adaxial side of the tendrils (Fig. 19B). In the following section, lateral branches were observed developing in the adaxial side of tendrils, coming out from the region where the expression domain was expanded in the previous section (Fig. 19C-D). In this region of the tendril, the expression of $A b F L O$ was confined to the adaxial domain of the tip of the lateral branches (Fig. 19E). Furthermore, the expression of $A b F L O$ presented a different pattern in the median region of the primordia of the tendril lateral branches, being more restricted and concentrated in the boundary between the abaxial and adaxial domains, as well as in the vasculature (Fig. 19F). In the tendril tip of P2 (Fig. 19G) a stronger expression of $A b F L O$ was detected in the adaxial domain when compared with the same region in P3. The section right below this region showed the same pattern of expression described for the corresponding region in P3 (Fig. 19H). However, the next sections through this region showed that are leaflet primordia that are developing in this region instead of tendril lateral branches (Fig. 19I). Sections through the basal region of the tendril primordium at $\mathrm{P} 3$ showed that the expression of $A b F L O$ is restricted to the vascular traces (Fig. 19I). Expression of $A b F L O$ is broader in the distal region of P1, comprising the whole adaxial domain (Figs. 19I-J). However, it becomes confined to the boundary between the abaxial and adaxial domains towards the median region of the tendril primordium (Figs. 19K-L). AbFLO is more weakly expressed in the basal regions of the primordium, with transcripts becoming restricted to the vascular traces. Furthermore, 


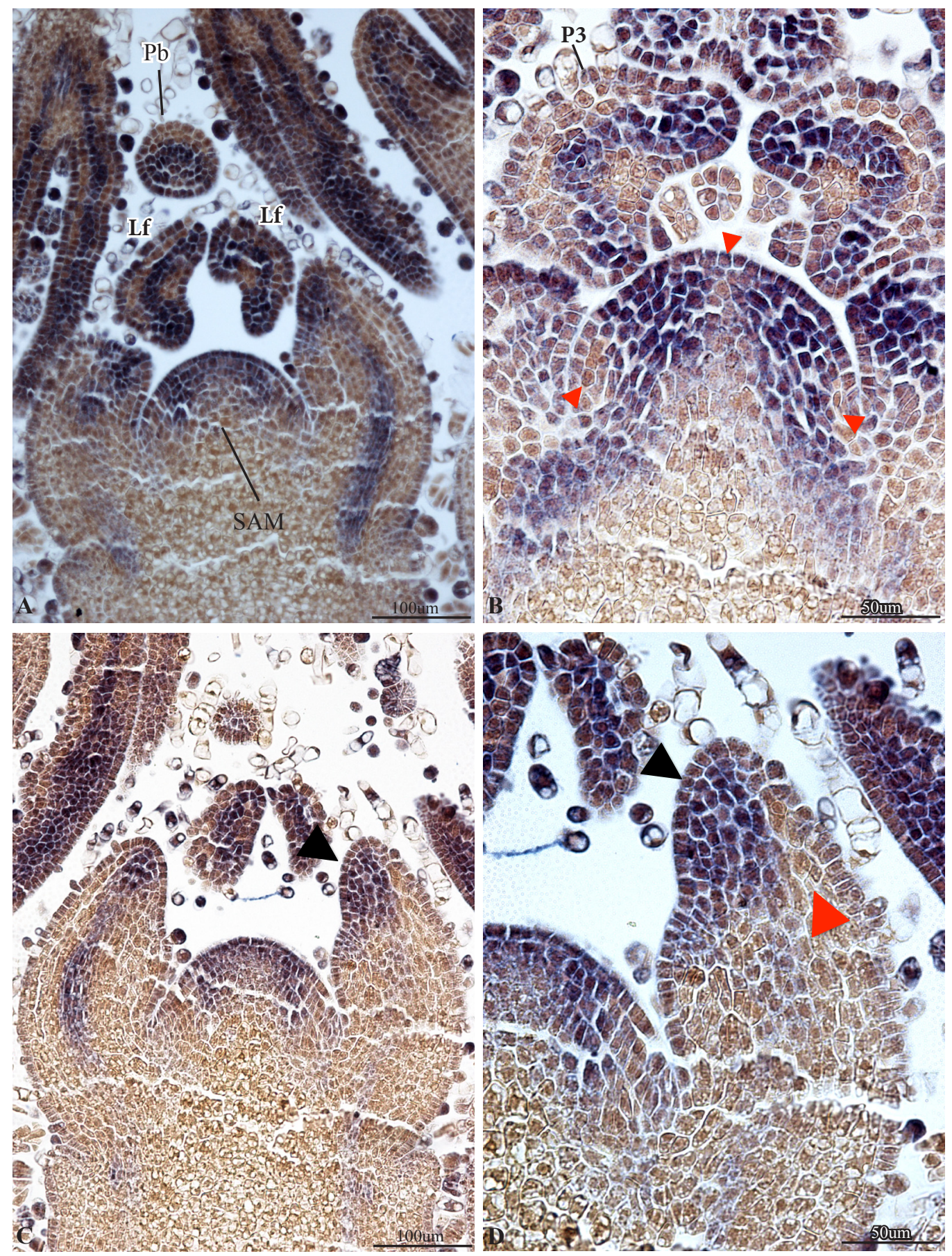

Figure 13. In situ hybridizations of $A b P H A N$ in shoot apices of $A$. buccinatorium. A. Accumulation of $A b P H A N$ transcripts in the SAM, leaflet, tendril primordia, and in the leaf primordium vasculature. B. AbPHAN transcripts were not detected in the flanks and in the center of the SAM (red arrows). AbPHAN was expressed in leaflet primordium in P3 stage, transcripts accumulated in the midrib vasculature, in the boundary between abaxial and adaxial domains, and in the developing blade. $\mathbf{C}$. Strong expression of AbPHAN in the tendril tip (arrowhead). D. Expression of AbPHAN concentrated in the adaxial region of the tendril tip (black arrowhead), and lacking in the abaxial region (red arrowhead). $\mathrm{Lf}=$ leaflet primordium; $\mathrm{Pb}=$ tendril primary branch. 

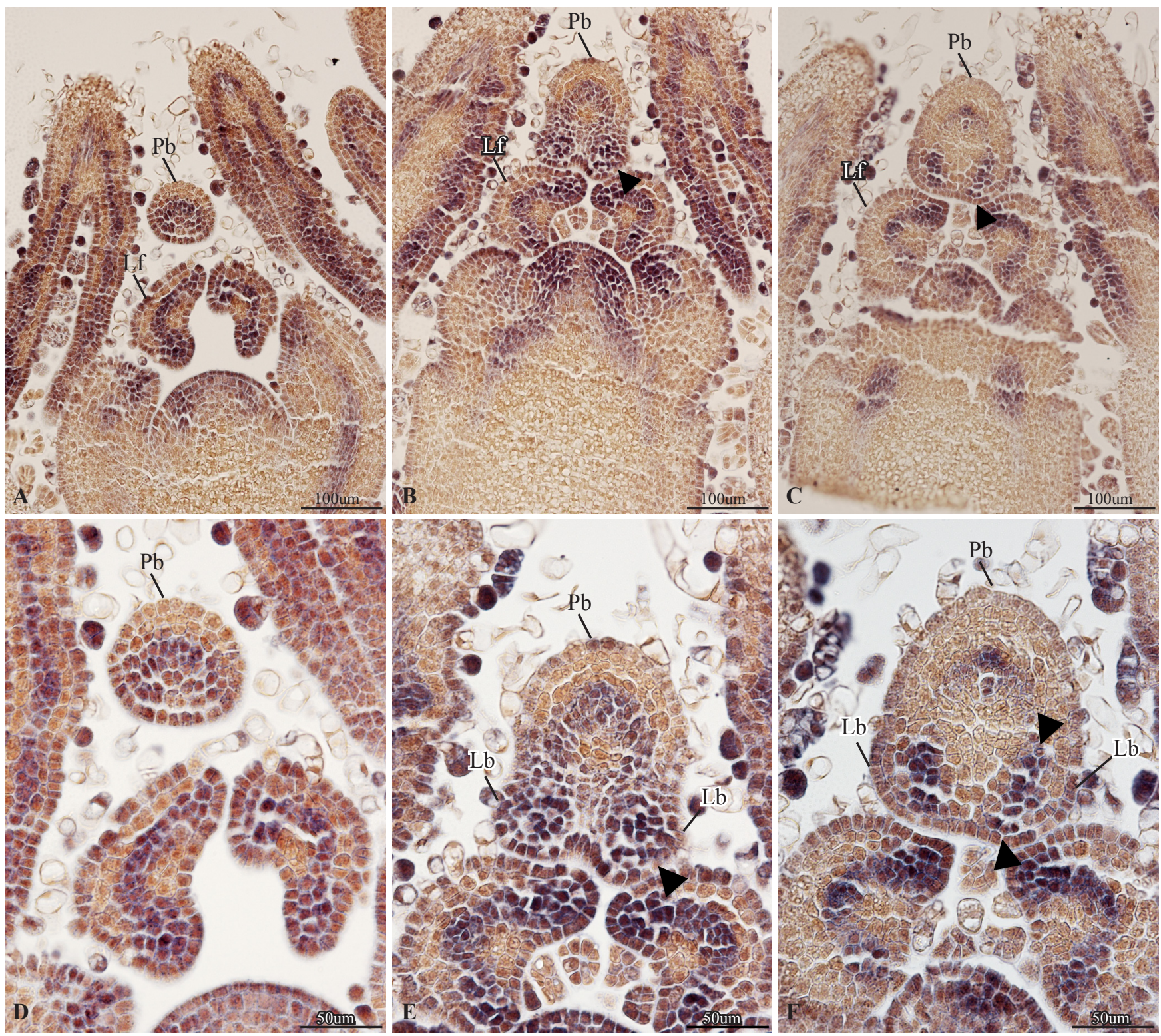

Figure 14. In situ hybridizations of $A b P H A N$ in leaves of A. buccinatorium at P3. A and D. AbPHAN expression was detected in the adaxial side of the tendril primary branch and in the leaflet primordia. This is showed in detail in the figure D. Note that only two layers of cell are not expressing $A b P H A N$ in the tendril primary branches. B and E. Strong expression of $A b P H A N$ in the region of the tendril where lateral branches are developing from the primary branch. $\mathbf{C}$ and $\mathbf{F}$. Accumulation of $A b P H A N$ transcripts in a more restricted domain of the tendril secondary branch primordium, possibly marking the adaxial domain (arrowheads in both figures) in a section passing right below the section presented in figures B and E.

AbFLO is expressed in the tip of the SAM (Fig. 19K), with sections below this region showing that the expresion of $A b F L O$ is excluded from the flanks of the SAM (Fig. 19M). A low concentration of $A b F L O$ transcripts was detected in the developing vascular bundles of the petioles at P2 and P3 stages (Figs. $19 \mathrm{~N}-\mathrm{O})$. 
The expression domain of FLO was broader in the other two focal taxa, D. unguis-cati and B. callistegioides. In the SAM of D. unguis-cati, DuFLO was expressed in the flanks, in several layers below the protodermis, and in the center of the meristem (Figs. 20A-B). DuFLO is strongly expressed in the new leaves that develop in the flanks of the meristem (Fig. 20B), in the leaflet primordia (Fig. 20C), and in the region of the tendril primordia where tendril lateral branches were being formed (Fig. 20A and 20C). In contrast, DuFLO expression was excluded from the region marking the boundary between the new emerging leaves and the meristem flank (Figs. 20D-E). More precisely, a few cells from the ground meristem, subjacent to P1, did not express DuFLO (Fig. 20E, red arrowheads). Furthermore, a constricted region of the protodermis, comprising of approximately 5 cells, did not express $D u F L O$ either. Moreover, expression of $D u F L O$ was also lacking from a band of cells subtending the axillary portion of the leaflet primordia, at the boundary between P3 and the meristem (Figs. 20E-F). In older primordia, expression of $D u F L O$ was detected in the developing lamina (Fig. 21A-B).

In $B$. callistegioides (simple tendrils), BcFLO presents an expression pattern that is similar to that of DuFLO in D. unguis-cati. Transcripts of BcFLO were detected in the SAM, leaf primordia, young stem, and axillary buds (Fig. 22A). However, no expression of $B c F L O$ was detected in the regions subtending the leaf primordium and axillary buds (Fig. 22B). Furthermore, a weaker expression of BcFLO was detected in a region of the primordium adaxial near the base of the developing leaflets (Fig. 22C). A strong expression of $B c F L O$ was detected in the tendril tip, especially in the adaxial side of the tendril primordia (Fig. 22C). In contrast, $B c F L O$ expression was excluded from the abaxial side of the primordia (Figs. 22C-E). In older primordia, BcFLO transcripts were evenly distributed through the developing lamina (Fig. 22D). Moreover, BcFLO is weakly expressed in the prophylls vasculature (Fig. 22F).

\section{Discussion}

In this study, we conducted a detailed histological analysis of different leaf parts in three representatives of Bignonieae (i.e., A. buccinatorium, B. callistegioides, and D. unguis-cati) that had different tendril types (i.e., simple, trifid, and multifid tendrils) and found out that all leaf parts, including tendrils, are bilaterally symmetrical. We further cloned the orthologs of STM, PHAN, and LFY/FLO from 

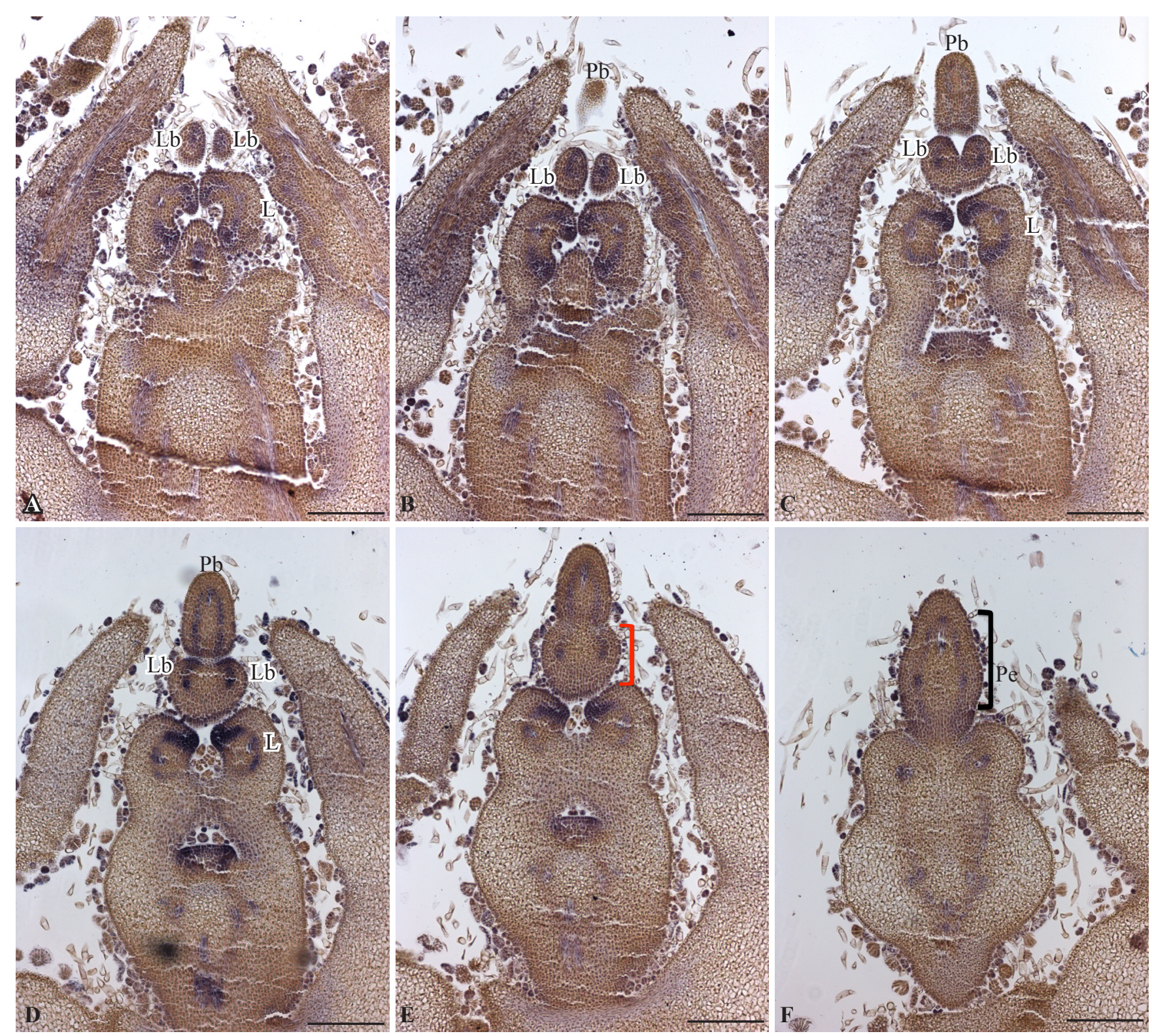

Figure 15. Serial sagittal sections of the leaf primordium of $A$. buccinatorium at the third stage of development showing in situ hybridizations of $A B P H A N$. A. Section at the distal region of the leaf primordium showing the accumulation of $A b P H A N$ trancripts in the adaxial region of the tendril and leaflet primordium (L). B and C. Tip of the tendril primary branch showing a lack of expression of $A B P H A N$. D. Expression of $A B P H A N$ in the vasculature of the tendril primary branch. E. Week expression of $A b P H A N$ in the tendril region right below its ramification (red bracket). F. Slight expression of $A b P H A N$ in the petiole vasculature. $\mathrm{Pe}=$ petiole. Scale $\mathrm{bar}=200 \mathrm{um}$.

the same species and analyzed their patterns of expression during leaf development. The interpretation of the molecular data in the light of the anatomical analysis allowed us to associate the patterns of gene expression with the establishment of tendril polarity. Transcripts of STM and LFY/FLO were detected in developing leaflets, revealing that tendrilled leaves of Bignonieae develop differently from those of pea. 
The data gathered in the present study provided important insights into the potential role of STM, PHAN, and $L F Y / F L O$ during the development of leaflets and tendrils.

\section{Polarity of tendrils and other leaf parts in Bignonieae}

Petiole polarity is generally correlated with leaf shape (Kim et al., 2003a). More specifically, plants with peltate palmate leaves generally show radially symmetric petioles. On the other hand, species with pinnate or peltate non-palmate compound leaves generally present petioles with a distinct adaxial domain, which are not completely radial in cross section. In order to further understand the origin of a cylindrical structure (tendrils) nested within an organ with dorsoventral polarity (leaves), we analyzed and compared histological sections of young and adult petioles, petiolules, and tendrils. We determined their plane of symmetry as an attempt to establish a connection between the polarity of petioles and petiolules and the rise of tendrils on the leaves.

All leaf parts analyzed from A. buccinatorium, B. callistegioides, and D. unguis-cati showed abadaxial polarity, with a more pronounced polarity in some parts (e.g., petioles) than others (e.g., tendrils). Petioles from $A$. buccinatorium and B. callistegioides showed a more pronounced ab-adaxial polarity than those of $D$. unguis-cati. In particular, the vasculature of $A$. buccinatorium and $B$. callistegioides never assumed a ring form, and had gaps that faced the adaxial side, even in the adults. In addition, petioles of $A$. buccinatorium developed wings or blade like outgrowth on the adaxial side. In contrast, the adult petiole of $D$. unguis-cati seems radial in symmetry although the young petioles of $D$. unguis-cati were more similar to the petioles from the other two species at this developmental stage. In particular, petioles were triangular in cross section and had the same gap in the vasculature facing the adaxial side, as the other species.

The bilateral symmetry of Bignonieae tendrils can be easily detected by the larger vascular bundle encountered on the abaxial side. This bundle can be identified from the first stages of development and remains distinct in the mature organ. Interestingly, although all leaf parts other than the leaflets have the same plane of symmetry, curious minor shifts in the general tissue organization were observed (Fig. 23). The two species with branched tendrils, A. buccinatorium and D. unguis-cati, showed the 


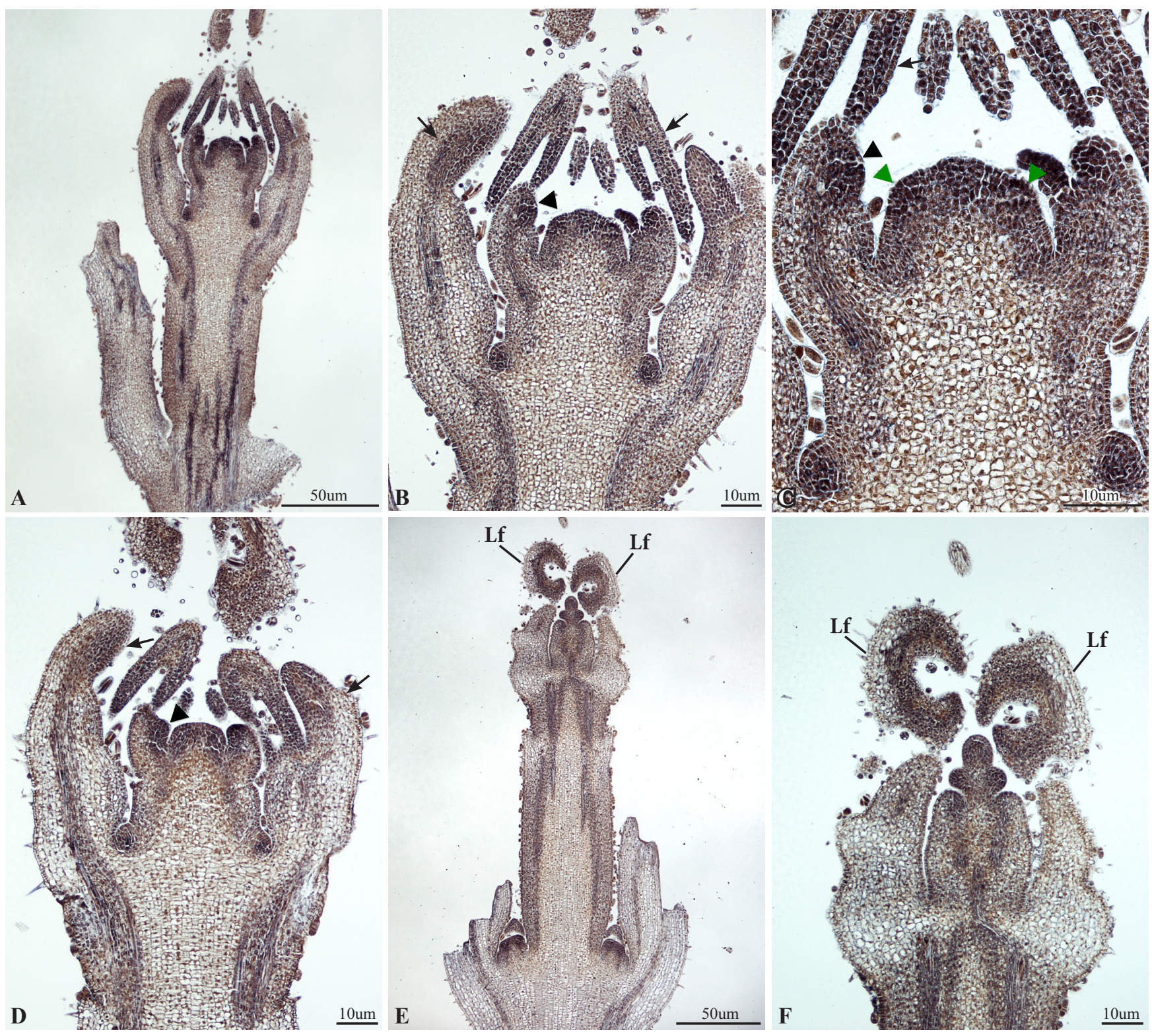

Figure 16. In situ hybridizations of DuPHAN in shoot apices of D. unguis-cati. A. DuPHAN mRNA was detected in the SAM, leaf primodium, axillary buds, stem, and vasculature of the leaf primordium. B. Higher magnification of the section in figure $\mathbf{A}$ showing the expression of DuPHAN in older leaf primordia (arrows), and during the formation of lateral branches of tendrils (arrowhead). C. Expression of DuPHAN in the flanks of the SAM (green arrowheads) where new leaves are beginning to develop. D. Strong expression of DuPHAN in the tissue proliferation that will give rise to leaflets (arrowheads). E. Expression of DUPHAN in the adaxial region of the older leaflet primordia. F. Detail showing the expression of DuPHAN in the adaxial region of the leaflet primordia.

most pronounced ab-adaxial polarity. In A. buccinatorium, tendril tips had blade-like tissue expansions that are very similar in structure to leaflet tips. This blade-like structure illustrates that the ability to form flattened organs is partially retained in the tendrils. At tendril maturity, this tip region undergoes a massive proliferation, giving rise to adhesive disks (Fig. 24). 
The abaxial and adaxial sides of leaflets have different types of epidermal cells. In Antirrhinum and pea, in particular, cells from the adaxial side of the midrib are different from those of the abaxial side. The needle-like leaflets of PHAN mutants of Antirrhinum and pea have cells that are typical from the abaxial epidermis throughout the circumference of the leaves/leaflets, providing further evidence of organ abaxialization (Waites and Hudson, 1995, 1998; Tattersal et al., 2005). In B. callistegioides and A. buccinatorium, the epidermal cells of tendrils are similar to those encountered on the midrib of the abaxial side of leaflets. On the other hand, the epidermal cells encountered throughout the tendril circumference of $D$. unguis-cati are similar to the epidermal cells encountered in the upper and lower epidermis of the midrib. More specifically, the leaflet midrib of D. unguis-cati have a ribbed projection on the adaxial side that is very similar to that formed in the tendrils (Fig. 25). The remaining cells of the tendril epidermis are similar to those encountered in the abaxial side of the leaflet midrib. These results indicate that the adaxial and abaxial domains were clearly retained in the tendrils of $D$. unguis-cati and that, even though tendrils seem to be radially symmetrical externally, the internal tissue organization of this organ actually has ab-adaxial polarity. This was also verified in the tendrils of pea, which have a larger vascular bundle in the abaxial side (Tattersal et al., 2005).

Pea tendrils have been thought to represent leaflets that lost their adaxial identity over evolutionary time (Lu et al., 1996; Tattersal et al., 2005), although the anatomical similarity between the rachis and tendrils of pea has also led to the interpretation that tendrils might represent an extension of the rachis instead (Tattersall et al., 2005). Molecular studies on CRISPA, the pea PHAN ortholog, showed that CRISPA mutants have radially symmetrical leaflets that are externally similar to tendrils. Besides loosing the leaflet blade and acquiring a cylindrical shape, PHAN mutants in pea and Antirrhinum, show abaxialized vasculature, with a solid central xylem bundle that is surrounded by a continuous circle of phloem (Waites and Hudson, 1995, 1998; Tattersal, et al., 2005). However, the development of tendrils in PHAN mutants seem to not be altered (Tattersal et al., 2005). The fact that the tendril in wild peas seem to have a different anatomical constitution compared to the abaxialized leaflets generated in $P H A N$ mutants has supported the hypothesis that tendrils represent extended rachises as opposed to radialized leaflets (Tattersal et al., 2005). However, the fact that tendrils do not naturally show the abaxialized 


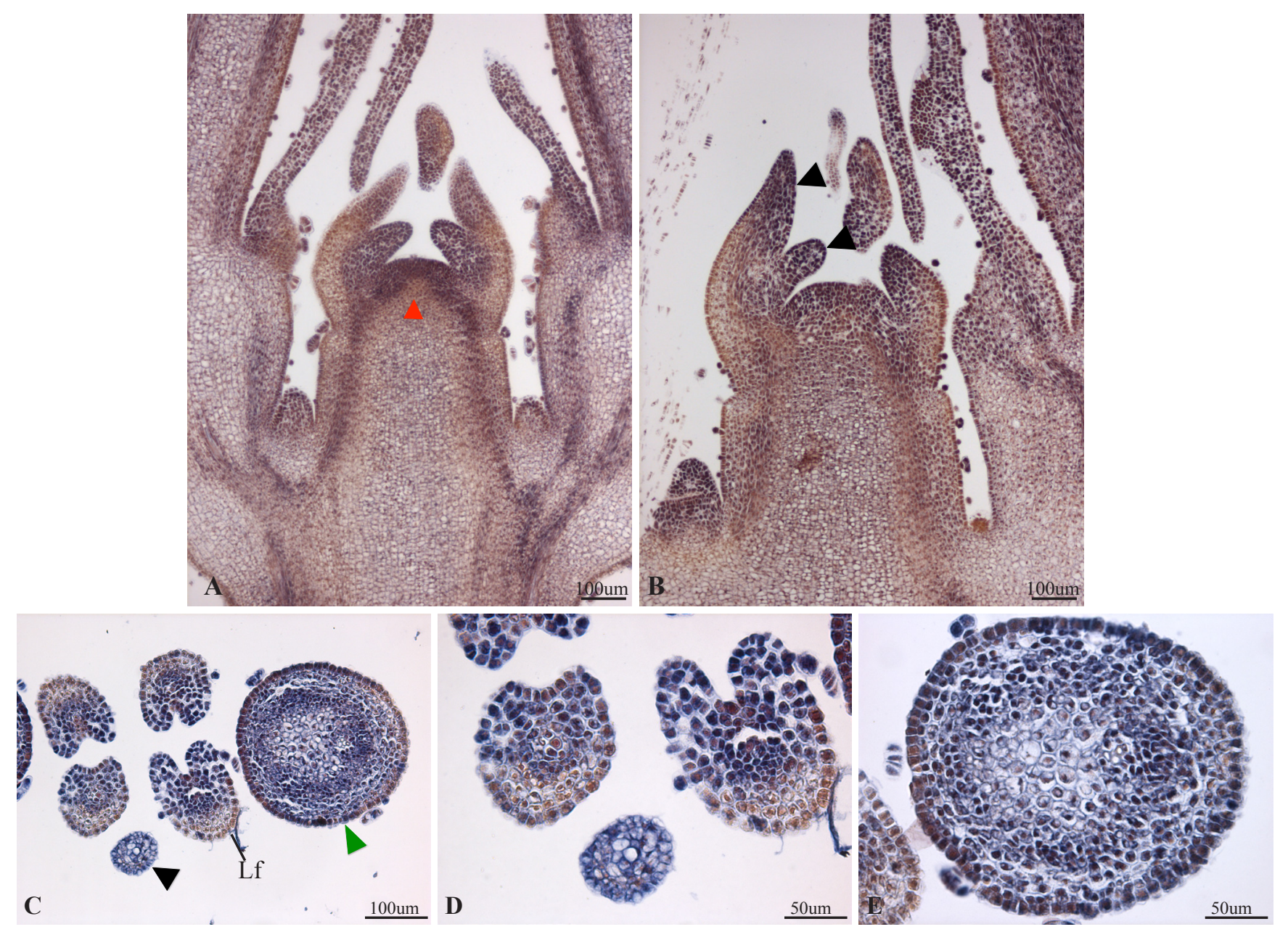

Figure 17. In situ hybridizations of $B c P H A N$ in shoot apices of $B$. callistegioides. A. BcPHAN mRNA was detected in the SAM, leaf primordium and in the stem vasculature, but not in the center of the SAM (red arrow). B. Expression of BcPHAN at the tendril tip and in the leaflet primordium (arrowheads). C. Expression of BcPHAN in the adaxial side of the leaflet primordium, and throughout the tendril tip (arrowhead), and median region (green arrowhead). D. Detail of the tendril tip illustrating the expression of $B C P H A N$. E. Detail of the tendril median region showing the expression of $B c P H A N$ throughout the whole tendril. $\mathrm{Lf}=$ leaflet primordium.

vascular arrangement encountered in leaflets of PHAN mutants, does not seem an adequate argument in favor of this hypothesis. The abaxialized esteles encountered in the leaflets of PHAN mutants are similar to the haplosteles encountered in the stem of ferns (Schmid, 1982). This type of stele is very rare within angiosperms, making it very unlikely that an angiosperm leaf would normally show this stele structure. It has also been hypothesized that the anatomical differences encountered between the leaflets of PHAN mutants and wild tendrils are attributable to tendrils being only partially abaxialized leaflets. However, this scenario makes it difficult to explain why a PHAN mutation does not affect tendril development in pea (Tattersal et al., 2005). The establishment of polarity represents a complex process that involves the 

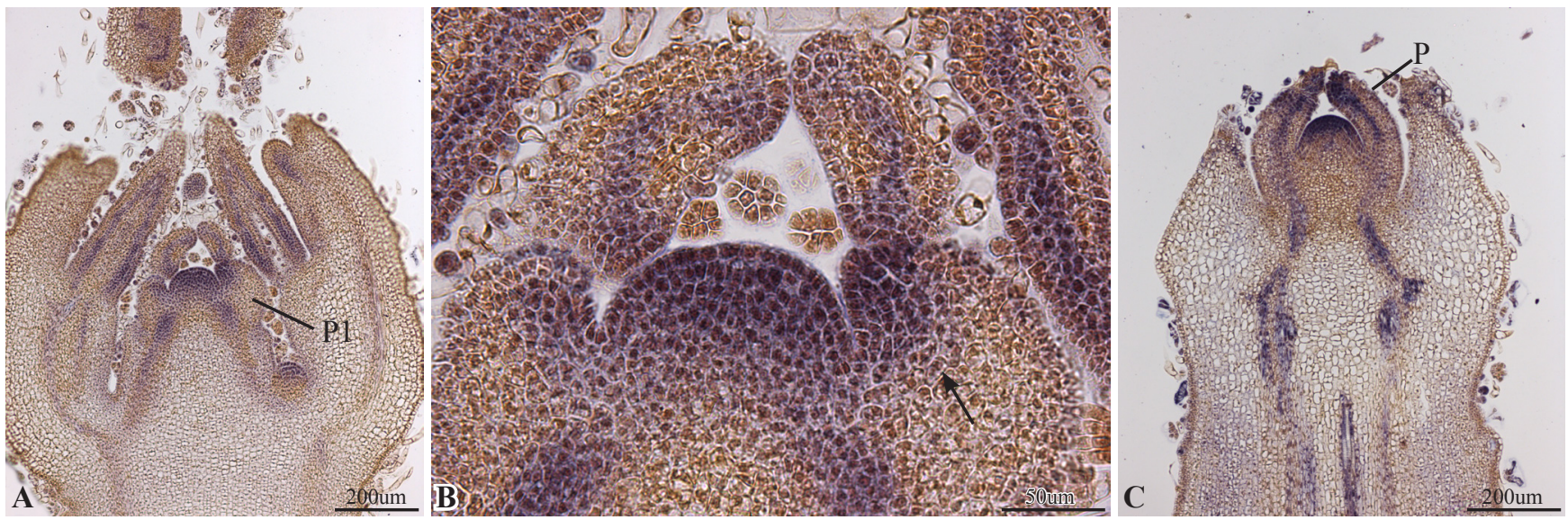

Figure 18. In situ hybridizations of $A b F L O$ in shoot apices of $A$. buccinatorium. A. Expression of $A b F L O$ in the SAM, leaf primordia, axillary buds, and stem vascular traces. B. Strong expression of $A b F L O$ in the adaxial region of the tip of the leaf primordium (arrow). C. AbFLO transcripts were detected in the axillary bud and in the vasculature of the prophylls. $\mathrm{P}=$ =prophyll.

formation of different tissues in specific regions of organs, and a coordinated multilayered control of individual mechanisms (Davies, 2005). It is currently known, however, that multiple genes associated with the establishment of the abaxial or adaxial identity regulate all of these events (Husbands et al., 2009). Hence, the lack of a convincing explanation of why tendril development is not affected in pea PHAN mutants does not represent a sufficient reason to reject the hypothesis that tendrils represent modified leaflets.

As mentioned earlier, the external similarity of leaf tendrils to leaflets from mutants of genes that regulate abaxial/adaxial identity has led to the hypothesis that tendrils might represent abaxialized leaflets (Waites and Hudson, 1995; McHale and Koning, 2004; Tattersal et al., 2005). Furthermore, it has also been shown that the expansion of leaf blades depends on established adaxial-abaxial domains as the juxtaposition of the abaxial and adaxial domains is a prerequisite to the outgrowth of the leaf blade (Waites and Hudson, 1995; McConnell et al., 2001). Thus, it is possible that the lack of an expanded lamina in the tendrils could result from disrupted adaxial-abaxial domain establishment, leading to the formation of abaxialized organs.

A heterochronic model compatible with the hypothesis that tendrils represent partially abaxialized leaflets was proposed to explain pea leaf development (Lu et al., 1996, Tattersall et al., 2005). The most well characterized mutants of pea leaves are afila (af) and tendril-less (tl). In afila plants, all leaflets are 
replaced by tendrils, while all tendrils are replaced by leaflets in $t l$ plants (Villani and DeMason, 1997). The heterochronic model considered the pleiofila mutant (afaf/tltl double mutant) as representing the ground state of pea leaves. During the development of pleiofila leaves, the leaf primordia would become parted and subsequently, leaflets would form at the tips of the ramifications of the leaf primordia. Under this scenario, tendrils would have arisen in pea by the precocious termination of the ramification program in the distal region of pea leaves, terminating the lamina outgrowth at the "ramification" tips (Lu et al., 1996). Thus, if the "branches" were left to fully develop (without tendril-less interference), leaflets would be formed at the tips of the ramifications. In this context, the "branches" of the leaf primordia would present an inherent capacity to form expanded blades. However, tendril-less would stop their development at the ramification step, not leading to the expansion of blades. If the ramifications of the leaf primordia indeed have a potential for blade expansion, then these regions probably show an inherent adaxial-abaxial polarity. So, considering this model, we can reason that although lamina expansion is dependent on a well-established adaxial-abaxial domain, the existence of an established adaxial-abaxial domain would not necessarily imply lamina expansion. Accordingly, tendrils might have adaxial-abaxial polarity, and still not develop a blade. In Bignonieae, expression of PHAN was detected delimiting the adaxial domain in tendrils, as well as in the lateral branches of tendrils, including the tendril regions in which no ramification or tissue expansion was seen (further details below).

Our histological studies indicated that Bignonieae tendrils are structurally different from those of pea. In particular, pea leaves have tendrils with an anatomical structure that is similar to that of the rachis. In contrast, Bignonieae tendrils seem to represent modified leaflets. More specifically, the vasculature organization of the tendrils of $D$. unguis-cati is similar to that of petioles, suggesting that tendrils of $D$. unguis-cati might be derived from petioles. On the other hand, the tendril epidermis of $D$. unguis-cati showed cell types on the abaxial and adaxial regions of the leaflet midrib suggesting that tendrils might represent modified leaflets. In contrast, no anatomical similarities was encountered between the tendrils and petioles of $A$. buccinatorium, but the leaf-like structure that develops at the tendril tips provides support for the hypothesis that these tendrils may represent modified leaflets. In B. callistegioides, the sole simple-tendrilled species examined, no anatomical similarities were encountered between tendrils 


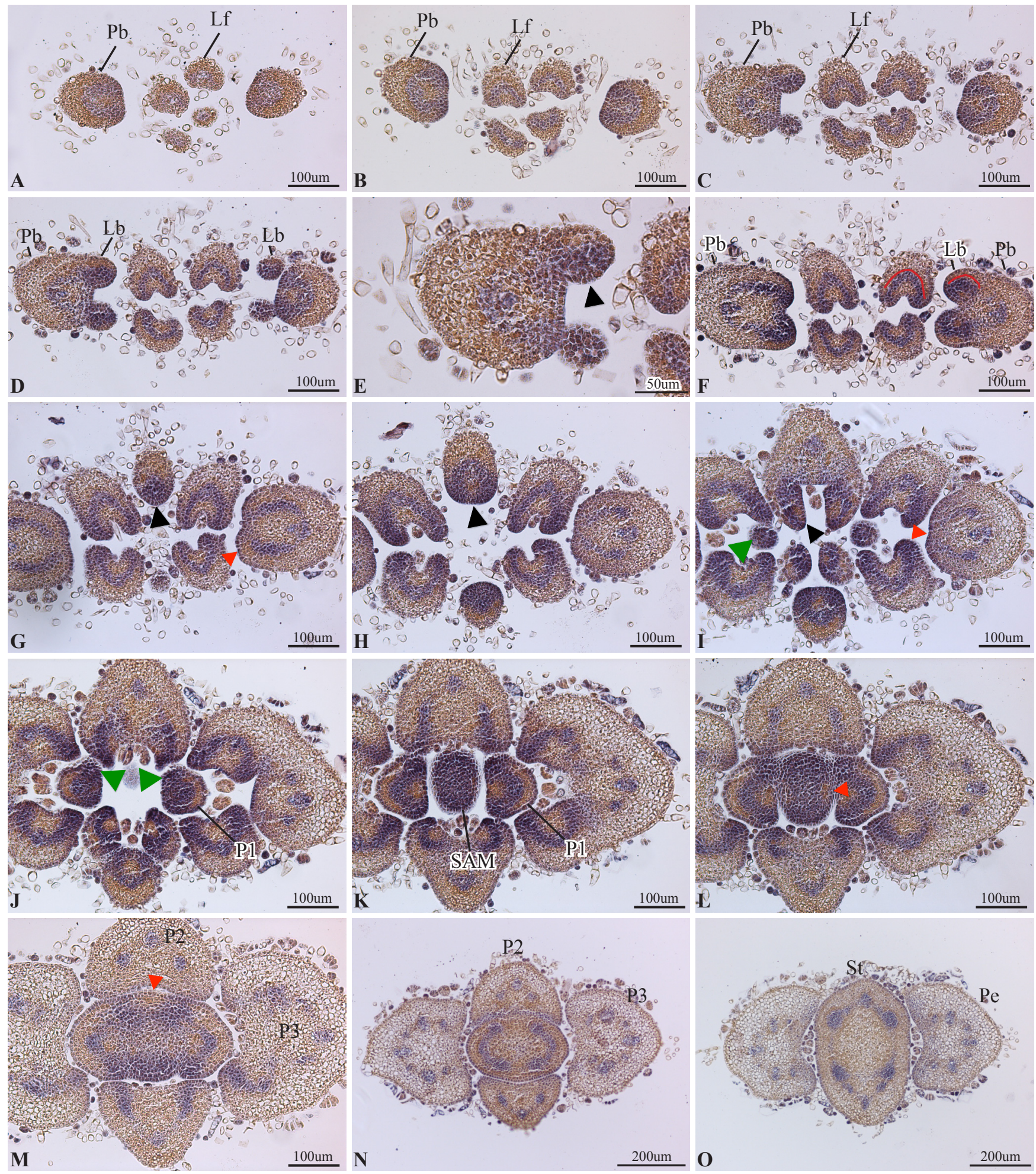


and leaflets. Such lack of similarity between these structures suggests that the simple tendrils of $B$. callistegioides may have stopped at earlier stages of development, hence lacking any of the leaflet features that would normally be formed at later stages of development according to the heterochronic model. In contrast, the branched-tendrilled species of Bignonieae, A. buccinatorium and D. unguis-cati, would have advanced further in the developmental pathway hence, producing higher orders of ramification, and tendrils characteristics that would be similar to leaflets. Interestingly, A. buccinatorium, the species with the most pronounced tendril polarity (including wings in the adaxial side) is the only species that has retained the capacity to produce flattened expansions (i.e., adhesive disks) in the tendril tips. Such observation corroborates earlier findings (Kim et al., 2003a), and suggests a correlation between petiole polarity and final leaf form. Indeed, it is possible that the regulation of the polarity establishment in tendrils of $A$. buccinatorium might be slightly different from that of B. callistegioides and D. unguis-cati, where tendrils of the latter never produce flattened structures associated.

\section{Gene orthology}

The gene trees reconstructed in the present study did not reflect the species phylogeny, but showed that Bignonieae orthologs are closely related to well-known orthologs from model species. Furthermore, the alignment of the nucleotide and protein sequences of STM, PHAN and LFY/FLO showed high degree of conservation among species of Bignonieae, the selected orthologs from model species, and those from

Figure 19. In situ hybridizations of $A b F L O$ in tranversal sections of the shoot apex of $A$. buccinatorium. A-B. Week expression of $A b F L O$ in the tendril and leaflet tips at P3. C-D. Transcripts of $A b F L O$ concentrated in the adaxial region of tendrils, where lateral branches are developing at P3. E. Detail of the tendril primordium showing strong expression of $A b F L O$ in the adaxial region of the tendril lateral branches (arrowhead). F. Expression of $A b F L O$ in the vasculature and in the boundary between the abaxial and adaxial domains of the lateral branches of the tendril. Note the coincident pattern of expression between the the leaflet and tendril lateral branches (red arcs). G-H. Transversal section below the region where the tendril lateral branches are being formed at $\mathrm{P} 3$, showing a lack of expression of $A b F L O$ in the adaxial region of the tendril at $\mathrm{P} 2$ (red and black arrows). I. Expression of $A b F L O$ throughout the tendril tip at P1 (green arrow), in the leaflet primordia at P2 (black arrow), and lack of expression in the adaxial side of the tendril at P3 (red arrow). J. Expression of AbFLO in the adaxial region at P1 (green arrows). K. Expression of $A b F L O$ throughout the SAM, in the P1 midrib vasculature, and in the boundary between the abaxial and adaxial domains. L. Lack of expression of AbFLO in a small area in the flanks of the SAM (red arrowhead). M. Lack of expression of $A b F L O$ in the flank of the meristem, marking the boundary between the next leaf primordium and the meristem (red arrow), and week expression of $A b F L O$ in the vasculature of petioles at P2 and P3 (N) and in the young stem (O). 


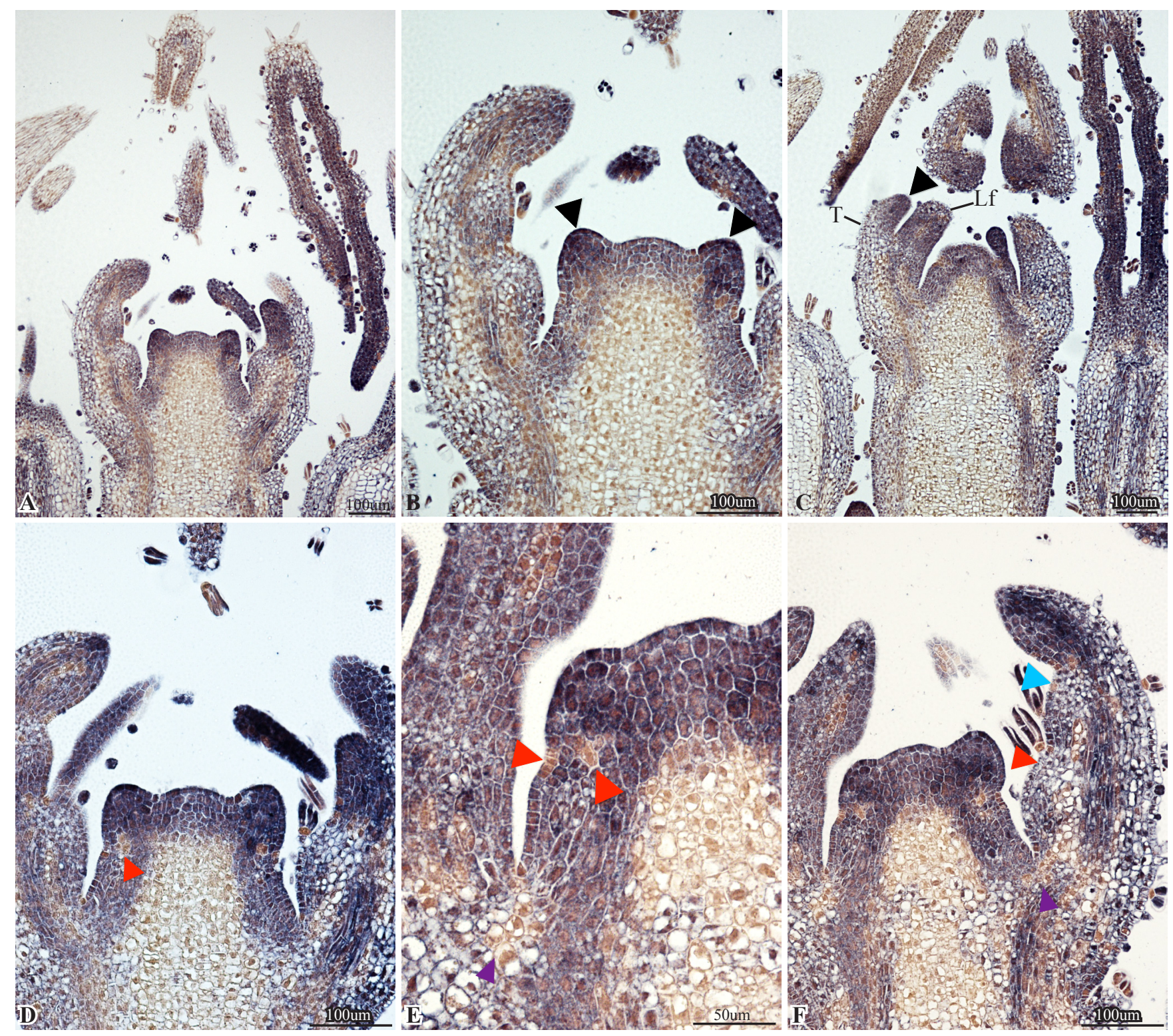

Figure 20. In situ hybridization of DuFLO in longitudinal sections of the shoot apex of D. unguis-cati. A. Expression of $D u F L O$ in the center and flanks of the SAM, and in leaf primordia. B. Detail of the shoot apex illustrating the strong expression of $D u F L O$ at P1 (arrowheads). C. Expression of DuFLO in the leaflet primordium and tendril tip (arrowhead) at P2. D. Lack of expression of $D u F L O$ in the region that comprises the boundary between the new emerging leaves and the meristem flanks (red arrowhead). E. Detail illustrating the lack of expression in the tissue that is subjacent to P1, that is the boundary between P1 and the meristem. Lack of DuFLO expression was also observed in some cells of the protodermis in the flanks of the SAM (red arrowheads). Note the lack of transcripts in the boundary between P3 and the meristem (purple arrowhead). F. Lack of $D u F L O$ transcripts in the boundary between the leaflet primordium and the tendril lateral branches at P3 (red arrowheads), and in the boundary between the tendril lateral and primary branches (blue arrowhead). Note that no expression of DuFLO was detected in the boundary between P3 and the meristem flank (purple arrowhead). Lf=leaflet; $\mathrm{T}=$ tendril. 


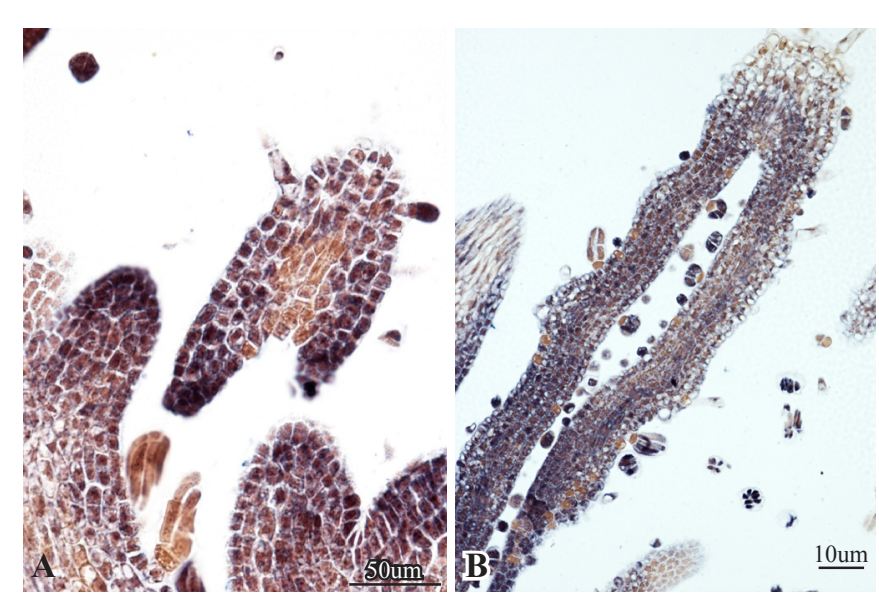

Figure 21. In situ hybridizations of DuFLO in the leaflet primordia of D. unguis-cati. A. Expression of DuFLO in the developing lamina but lacking from the midrib vasculature of a younger leaflet. B. Strong expression of DuFLO throughout the leaf blade, and low expression in the midrib vasculature of older leaf primordia.

representatives of the Lamiales. These pieces of evidence confirm that the genes cloned in this study are orthologous to the correspondent genes from model taxa. More specifically, DuSTM, $B c S T M$, and $A b S T M$ are more closely related to STM proteins from representatives of the Solanales than are to other representatives of the Lamiales. Interestingly, the clade formed by BigSTM is sister to LeT6 from tomato, another compound-leaved species. This close relationship is also indicated by the high nucleotide similarity between BigSTM and Solanaceae taxa (see Results). In addition, sequences of Bignonieae generally shared the same residue type with LeT6 in the most variable positions of the aminoacid alignment (Fig. 2).

The BigPHAN clade was sister to PHANTASTICA, from Antirrhinum majus, with LePHAN (Lycopersicum eculentum) and NtPHAN (Nicotiana tabacum) also being included in this same clade, and following the same pattern of relationships found with STM. The close relationship between the PHAN orthologs and the Solanaceae orthologs was also supported by the nucleotide and aminoacid alignments. In particular, Bignonieae sequences share the same residue type with Anthirrinum, tomato, and Nicotiana in the conserved regions outside the MYB domain. The high similarity found between Bignonieae (Lamiales) and Solanaceae orthologs might reflect the close phylogenetic proximity between the two plant orders (APG III, 2009).

The cloned $L F Y / F L O$ from Bignonieae was a region nested within the $\mathrm{C}$ domain, which is a DNA binding domain that is highly conserved among angiosperms (Maizel et al., 2005). Thus, the high degree of conservation observed in the $L F Y / F L O$ amino acid alignment was expected (Fig. 6). DuFLO, BcFLO, and $A b F L O$ formed a monophyletic group that was poorly supported as sister to FLORICAULA, from Antirrhnum majus (bootstrap support $>50 \%$ ). Despite the low bootstrap support, the alignment shows a 

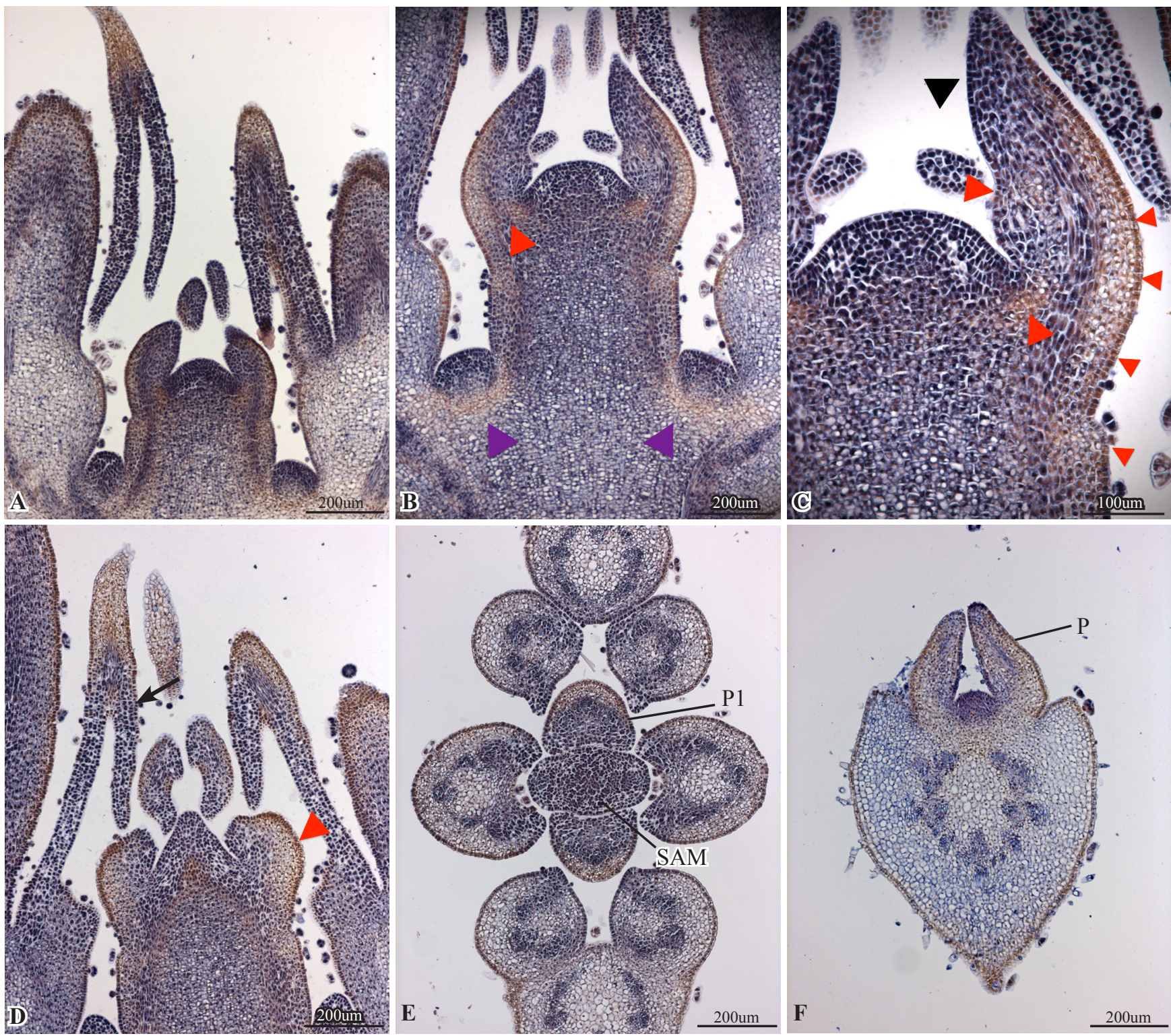

Figure 22. In situ hybridizations of $B C F L O$ in the shoot apices of $B$. callistegioides. A. Transcripts of $B c F L O$ in the SAM, leaf primordia, and axillary buds. B. Lack of $B c F L O$ in the boundary between the meristem and the axillary buds (purple arrowhead), as well as between the meristem and the leaf primordium (red arrowheads). C. Expression of BcFLO in the tendril tips (black arrowhead), with a lack of expression of $B c F L O$ indicated by red arrowheads. D. Lack of expression of $B c F L O$ throughout the abaxial side of the leaf primordium (red arrowhead), with the expression of $B c F L O$ throughout the developing lamina (arrow). E. Expression of $B c F L O$ in the entire SAM and in the adaxial side of P1. F. Strong expression of BcFLO in the axillary bud meristem and weak expression in the vasculature of the prophylls. 
high level of conservation between Bignonieae and other taxa, including the ortholog sequence from the outgroup Pinus radiata. Such high levels of sequence conservation corroborate the orthology between BigFLO and $L F Y / F L O$, with the low bootstrap support of most branches of the $L F Y / F L O$ phylogeny likely resulting from the low levels of sequence variation.

\section{STM, PHAN and $L F Y / F L O$ are expressed during tendril development in Bignonieae}

In this study we compare the expression patterns of BigSTM, BigPHAN and BigFLO during leaf development in representatives of Bignonieae with the patterns described to other compoundleaved species, such as tomato and pea. We further discuss the possible role of these genes during tendril formation in Bignonieae.

SHOOTMERISTEMLESS. In contrast to simple leaf primordia, compound leaf primordia keep an organogenetic zone in their margins where leaflets are formed; this tissue is called blastozone (Hagemann and Gleissberg, 1996; Champagne and Sinha, 2004; Barkoulas et al., 2007). To date, two genes are known to regulate blastozone function in seed plants, Class 1 homeodomain KNOTTED1-like (KNOX1) and LEAFY/FLORICAULA (Hofer et al., 1997; Bharathan et al., 2002). Even though KNOX1 transcription factors are primarily involved in the maintenance of the undifferentiatiated state of cells in the shoot apical meristem (Long et al., 1996), KNOXI also mediates the regulation of compound leaf development in several seed plant lineages (Bharathan et al., 2002). In compound leaves, KNOX1 genes are expressed in the blastozone, extending the meristematic capacity of this tissue, delaying the transition from the primary morphogenesis to secondary morphogenesis, and allowing the formation of leaflets (Bharathan et al., 2002; Hay and Tsiantis, 2010).

In early stages of the leaf development of Solanum lycopersicum, LeT6, the tomato STM ortholog, is highly expressed in the vascular traces and developing leaflet primordia. In older stages, LeT6 is expressed in the midrib vascular trace, and in a band of tissue that connects the midrib vascular trace and the leaflet margins (region called as "boundary between adaxial and abaxial domains" herein; Parnis et al., 1997; Janssen et al., 1998; Kim et al., 2003b). In young leaves of tomato, the expression of KNOX is 


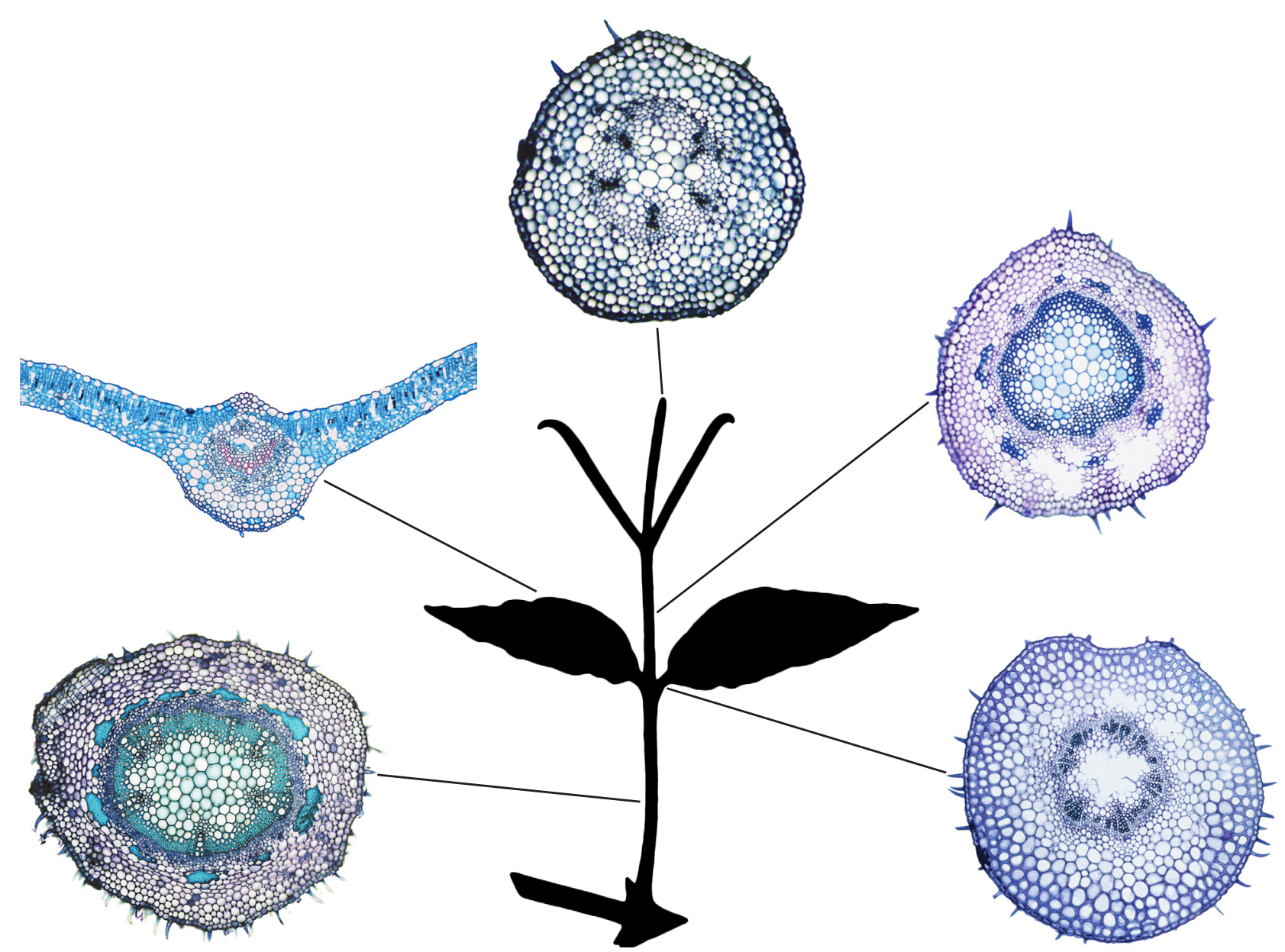

Figure 23. Schematic diagram of the leaf of D. unguis-cati illustrating the shifts in polarity. Anatomical sections illustrate the diverse internal organization of tissues in the different leaf parts.

restricted to leaf midribs and lateral veins (Parnis et al., 1997). In Bignonieae, STM mRNA was detected in the SAM and developing leaves, indicating that the blastozone activity of Bignonieae leaves is also regulated by $K N O X 1$, as reported for others compound-leaved species (Brarathan et al., 2002; Hay and Tsiantis, 2006). Early in leaf development, $S T M$ is expressed throughout the leaflet primordia, while the activity of STM is restricted to the boundary between adaxial and abaxial leaf domains and midrib vasculature in later stages of development. This expression pattern is consistent with the patterns of STM expression reported for tomato (Parnis et al., 1997; Janssen et al., 1998; Kim et al., 2003b). The expression of STM is strongly associated with the initiation of leaflets, as well as with the initiation of tendril lateral and tertiary branches. More specifically, STM mRNA was detected in the adaxial regions of the tendril primary branches, where tendril tertiary branches develop, as well as in the adaxial domain 

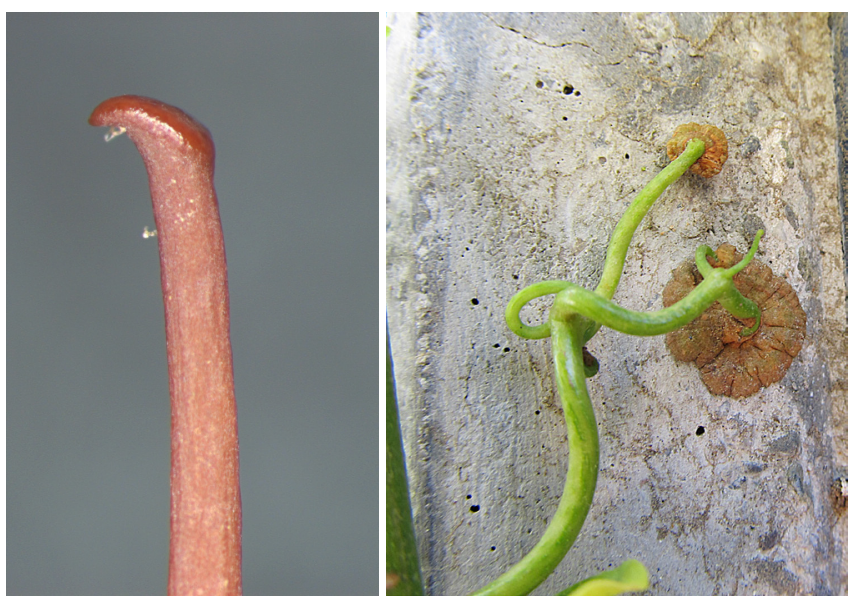

Figure 24. Tendrils of $A$. buccinatorium. A. Young tendril, illustrating the leaf-like expansion formed at the tendril tip.

B. Mature tendril, showing adhesive disks in the tendril tip.

of simple tendrils, which is likely associated with the lack of formation of lateral branches in this species. Indeed, expression of STM in simple tendrils was clearly associated with regions undergoing extensive cell division, which is consistent with the role of STM in preventing cell differentiation (Hay and Tsiantis, 2006; Shani et al., 2009). STM mRNA was also detected in the developing blade of young leaves of the three species of Bignonieae examined. In D. unguis-cati and B. callistegioides, STM was expressed uniformly through the lamina, while A. buccinatorium STM was strongly expressed in the lateral provascular strands, similar to what has been documented in tomato (Parnis et al., 1997).

Immunolocalization experiments demonstrated that $K N O X$ proteins accumulate in the leaf primordia of Cardamine hirsuta, a close relative of Arabidospsis thaliana that presents compound leaves (Hay and Tsiantis, 2006). The pattern of protein accumulation encountered in C. hirsuta was similar to that of LeT6 in tomato, and BigSTM in Bignonieae. In contrast, the expression of ChSTM was restricted to the outer cells layers of the leaf primordia, differently from what was observed for LeT6 and BigSTM (Hay and Tsiantis, 2006). Despite this difference in expression, silencing of STM in C. hirsuta indicated that STM maintains cells in an undifferentiated state longer, thus promoting leaflet initiation, as encountered in other compound-leaved species (Hay and Tsiantis, 2006). This pattern of reactivated expression of $K N O X$ in compound leaf primordia was also documented in other plant species. In particular, studies with compound-leaved Papaveraceae indicated that the expression of STM can vary between closely related 


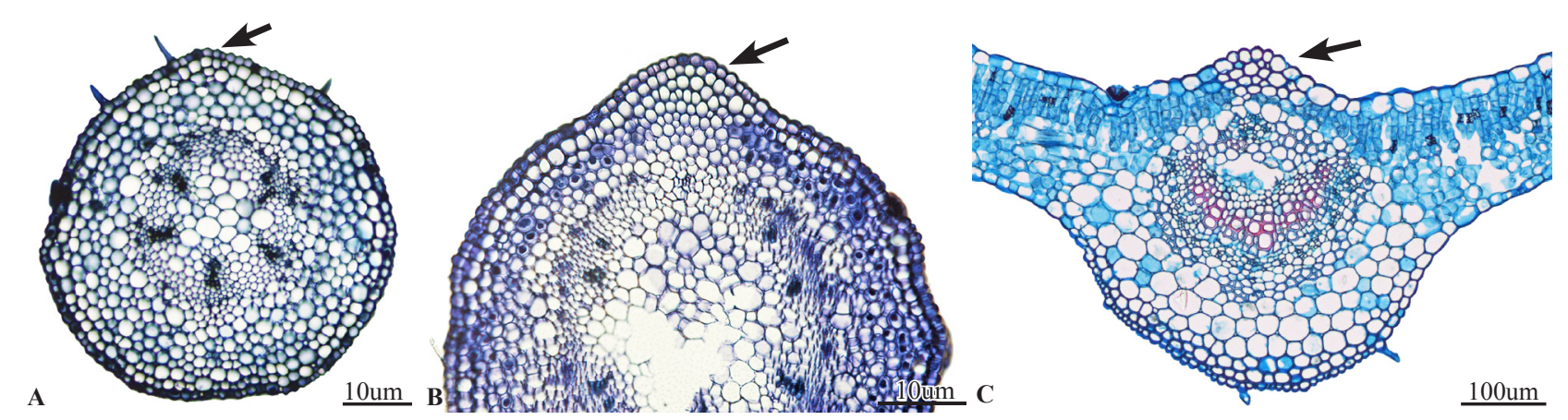

Figure 25. Dolichandra unguis-cati, tendril and leaflet anatomy, showing the ribbed tissue projection in the adaxial side of the tendrils (A and $\mathbf{B}$ ) and leaflets $(\mathbf{C})$, pointed out by arrows. Note that outside this region the epidermal cells are similar to the cells of the abaxial side of the leaflet midrib in $\mathbf{C}$.

species (Groot et al., 2005). In Eschscholzia californica, expression of STM was reactivated during leaflet development, while STM does not seem to be expressed during any stage of leaf development in Chelidonium majus (Groot et al., 2005). This data indicate that the function of KNOX may vary between closely related species bearing the same leaf type. In C. majus, specifically, it is possible that another KNOX1 gene may have taken over the function executed by STM in E. californica (Groot et al., 2005). In Bignonieae, the main difference encountered among the studied taxa was the weaker expression of STM during the development of simple tendrils as opposed to the stronger expression of STM in branched tendrils. The diminished expression of STM in simple tendril is likely associated with the lack of tissue proliferation in the blastozone responsible for the formation of lateral branches in branched tendrils.

PHANTASTICA. PHANTASTICA (PHAN) is a MYB-domain transcription factor that was described for Antirrhinum (Waites and Hudson, 1995). ASYMMETRIC LEAVES1 (AS1), and ROUGH SHEATH2 (RS2), are the MYB-domain transcription factors orthologs of PHAN that have been described for Arabidopsis and maize, respectively (Timmermans et al., 1999; Byrne et al., 2000). AS1, RS2, and PHAN are collectively known as ARP genes (Harrison et al., 2005). ARP genes are transcribed in organ founder cells and down-regulate $K N O X$ genes in leaf initials (Waites et al., 1998; Timmermans et al., 1999; Tsiantis et al., 1999; Byrne et al., 2000). In addition, ARP genes also present important roles for the establishment of adaxial-abaxial polarity in Antirrhinum, Nicotiana, tomato, and Cardamine hirsuta (Waites and Hudson, 1995; Kim et al., 2003a; McHale and Koning, 2004; Hay and Tsiantis, 2006). In tomato, expression of LePHAN was detected in the SAM, leaf primordia, and stem vascular traces. In 
young leaf primordia of tomato, LePHAN transcripts were detected throughout leaf primordia, however, LePHAN transcripts were restricted to the adaxial side of leaflets at later stages of development (Kim et al., 2003a, b). In subsequent stages of leaf development, LePHAN was strongly expressed in the leaflet primordia and in the developing leaflet lamina (Kim et al., 2003a, b).

In Bignonieae, expression of PHAN was detected in the SAM and developing leaves, similarly to the expression pattern documented for tomato. However, $P H A N$ transcripts were confined to the adaxial side of the tips of the young leaf primordia in Bignonieae, but were distributed throughout the young leaf primordia in tomato. In $A$. buccinatorium in particular, $P H A N$ was not expressed in the center of the SAM. As this species has opposite phyllotaxy, this lack of expression may be interpreted as a lack of expression of PHAN in P0. Alternatively, P0 may be positioned in the lateral region of the SAM, where strong expression of PHAN was detected (Fig. 13B). In this case, $P H A N$ would not be expressed in the center of the SAM, a pattern that is common in other angiosperms (Waites et al., 1998; Timmermans et al., 1999; Tsiantis et al., 1999; Byrne et al., 2000, Kim et al., 2003b). Expression of ARP genes is generally detected in leaf founder cells, where they repress $K N O X 1$ expression, allowing some degree of differentiation of tissues and the emergence of new leaves. In Antirrhinum, maize, Arabidopsis, and Nicotiana, expression of PHAN was documented in the leaf primordia but not in the center of the SAM (Waites et al., 1998; Timmermans et al., 1999; Tsiantis et al., 1999; Byrne et al., 2000,). Furthermore, lower levels of mRNA were detected in the center of the SAM than in the leaf primordia of tomato (Kim et al., 2003b). In contrast, expression of PHAN was detected throughout the SAM in D. unguis-cati, including the central region of the SAM and the flanks where new leaves were developing.

In Bignonieae, PHAN is strongly expressed during the initiation and development of leaflets, tendril lateral branches, and tendril tertiary branches. In A. buccinatorium, for instance, the expression of PHAN was higher in the region where tendrils were branching, and weaker in the tendril region right below the branching point, corroborating the importance of the expression of PHAN for ramification development. In the young primordia (e.g., P1 and P2), PHAN is expressed in the adaxial domain of the leaf primordium. In older stages, during leaflet development (e.g., P3), the expression of $P H A N$ is restricted to the midrib vasculature, and to the boundary between the adaxial and abaxial domains. In 
early $\mathrm{P} 4, A b P H A N$ is expressed in the adaxial side of the tip of the tendril lateral branches. Furthermore, the expression pattern of $A b P H A N$ changes in the median region of the lateral branch, and $A b P H A N$ mRNA is identified in the boundary between the adaxial and abaxial domains.

The same pattern of expression encountered in the tendril lateral branches of A. buccinatorium (between adaxial and abaxial domains), is observed in the leaflets of this same species, in the leaves of N. sylvestris and A. thaliana (McHale and Koning, 2004; Iwakawa et al., 2007), and in the leaflets of several compound leaved species (Kim et al., 2003a). In N. sylvestris specifically, NsPHAN is expressed throughout the emerging blade primordia, becoming restricted to the middle mesophyll in the expanding lamina (McHale and Koning, 2004). Similarly, AS1 transcripts were detected throughout young stages of the leaf primordium in $A$. thaliana, but AS1 gradually became restricted to the central region between the adaxial and abaxial domains in subsequent stages (Iwakawa et al., 2007). In Cardamine hirsuta, a close relative of $A$. thaliana with compound leaves, expression of ChAS1 was detected in the leaves but not it the SAM (Hay and Tsiantis, 2006). Unfortunately, however, more detailed studies of the patterns of PHAN expression are still lacking in C. hirsuta, and data is still not available on the patterns of expression of PHAN throughout the development of leaves.

Expression of PHAN in the SAM, stem and leaf vascular traces was detected in a variety of angiosperm species with compound leaves (Kim et al., 2003a). In particular, PHAN transcripts were detected throughout the whole adaxial side of the leaf primordia of the pinnately-compound leaved species, resembling the expression of $L e P H A N$ in tomato. In contrast, the expression of PHAN was confined to the distal region of the leaf primordia in the peltate palmate compound leaved species (Oxalis regnellii and Schefflera actinophylla). These species do not show anatomical evidence of bilateral symmetry in the petiole, and no PHAN transcripts were detected in the proximal region of the leaf primodium, which is radial in symmetry and will originate the petioles. In this study Vitex cannabifolia, a member of the Lamiales with non-peltate palmate compound leaves, presented a pattern of PHAN expression that was similar to that encountered in the species of Bignonieae analyzed herein.

In pea, the expression of $C R I$ (PHAN ortholog) is restricted to the middle mesophyll layers of 
the leaflet primodia, and is not polarized in the tendril primordia (Tattersall et al., 2005). This pattern is different from what was found in D. unguis-cati and A. buccinatorium, in which the expression of PHAN was restricted to the adaxial side of leaflets and to the tendril primordia. On the other hand, the expression of $C R I$ was similar to that described for B. callistegioides, a simple-tendrilled species, in which PHAN was expressed throughout the tendril primodia. Interestingly, $B$. callistegioides also presented the less accentuated bilateral symmetry among all species of Bignonieae examined, resembling pea tendrils. However, PHAN mutants did not lead to any changes in the development of pea tendrils (Tattersall et al., 2005). Nevertheless, pea leaves are regulated by $L F Y / F L O$, and no $K N O X 1$ expression is detected during leaf development. In contrast, expression of STM (KNOX1 gene) was detected during leaf development in B. callistegioides, and this gene probably has an important role during leaf development in this species. Given the epistatic relationship between PHAN and STM, it is possible that PHAN may present a higher impact for the establishment of polarity in B. callistegioides than it does in pea.

In D. unguis-cati and A. buccinatorium, the expression of $P H A N$ is polarized and restricted to the adaxial domain, thus not seeming disrupted. Therefore, other polarity determinants must be involved in the establishment of polarity and must be responsible for the absence of lamina development in the tendrils of these species. It has been hypothesized that the maintenance of well defined adaxial and abaxial domains during leaf development can be achieved through mutually antagonistic relationships between polarity determinants (Sun et al., 2002). Furthermore, the well-defined boundary between the adaxial and abaxial domains, as well as the juxtaposition between them is necessary for the expansion of the leaf lamina (Waites and Hudson, 1995; McConnell et al., 2001). Thus, it is possible that other genes involved in adaxial identity (e.g., PHAVOLUTA, REVOLUTA and PHABULOSA; McConnell et al., 2001) and/or genes responsible for abaxial domain establishment (e.g., YABBYs and KANADI; Eshed et al., 2004) may be involved in tendril formation. However, the exact function of ARP genes during the development of tendrils in Bignonieae can only be accessed through functional studies.

Interestingly, radialized leaves of PHAN mutants of Nicotiana sylvestris showed expression of PHAVOLUTA, a determinant of adaxial identity, in a pattern that was similar that encountered in wild type plants (McHale and Koning, 2004). In addition, the radialized leaves of N. sylvestris PHAN 
mutants presented subtended axillary meristems that are generally thought to be associated with adaxial leaf identity. $N$. sylvestris PHAN mutants also developed leaf blades, although presented a delayed differentiation of the palisade parenchyma. These findings indicate that even though $P H A N$ was silenced in those lineages, adaxial features were still present suggesting that $P H A N$ does not represent the major adaxial determinant in this species, possibly only being involved with the timing of differentiation of cell layers (McHale and Koning, 2004; Sun et al., 2002).

In A. thaliana, AS1 represses KNOX gene expression in the leaf (Byrne et al., 2000). On the other hand, coexpression of $K N O X$ and ARP proteins is observed in leaves of many compound leaved species (Kim et al., 2003a; Hay and Tsiantis, 2006). Coexpression of PHAN and STM may be involved not only in the activity of the blastozone during compound leaf development, but might also be involved in the maintenance of the indeterminacy state in other leaf regions where meristematic activity is prolonged, like in basal meristems of Streptocarpus (Nishii et al., 2010). In representatives of Bignonieae, PHAN is expressed in overlapping domains with STM during leaf development, similar to what has been documented for several other compound leaved species, likely allowing the rise of compound leaves in all of these taxa (Kim et al., 2003b).

LEAFY/FLORICAULA. The expression of $L F Y / F L O$ represents another pathway for the maintenance of the undifferentiated state of leaf margins in angiosperms. LFY/FLO regulates leaf development in Pisum sativum, which does not express KNOX1 genes in the leaf primordia at any stage. (Hofer et al., 1997, 2001; Tattersall et al., 2004). In pea, PSKN1 (STM ortholog) is expressed in the SAM but completely excluded from leaf primordia. (Hofer et al., 2001). In the species of Bignonieae analyzed in this study, transcripts of $L F Y / F L O$ were detected in the SAM, in the leaf primordia, and in the axillary buds. However, the patterns of expression varied between species, with D. unguis-cati and B. callistegioides presenting a similar pattern of $L F Y / F L O$ expression, and A. buccinatorium presenting an expression of $L F Y / F L O$ that resembles that of PHAN in this same species.

In $A$. buccinatorium, more specifically, the expression of $A b F L O$ was concentrated at the adaxial regions of the tips of the leaf primodia. In older stages of leaf development, LFY/FLO transcripts 
accumulate at the boundary between the abaxial and adaxial domains, and in the midrib vasculature. Contrary to the patterns of expression detected for PHAN, AbFLO is weakly expressed at the tendril tips, but more strongly expressed in the adaxial side of the tendrils, right below the tendril tips. In the median region of the tendrils $A b F L O$ is expressed in the boundary between leaf domains. In this region, strong expression of $A b F L O$ was detected in the tissue bulge that gives rise to lateral branches, indicating its importance for the establishment of lateral branches in tendrils. Sections in the basal region of P3 tendril primordia showed that the expression of $A b F L O$ is restricted to the vascular traces. Furthermore, $A b F L O$ is expressed in the tip of the SAM, and sections below this region showed that $A b F L O$ expression is excluded from the flanks of the SAM.

In D. unguis-cati and B. callistegioides, the other two species of Bignonieae studied, the expression domain of $L F Y / F L O$ was broader. In particular, $L F Y / F L O$ was expressed in several layers below the protodermis in the flanks of the SAM, as well as in the center of the meristem. LFY/FLO orthologs were also strongly expressed in the new leaves that were developing at the flanks of the meristem, in the leaflet primordia, and in the regions of the tendril primordia where tendril lateral branches were being formed. Furthermore, FLO expression was excluded from the region that marks the boundary between the new emerging leaves and the meristem flanks. Besides, FLO was also excluded from a constricted region of the protodermis, with approximately 5 cells. However, expression of $L F Y / F L O$ was detected in the developing lamina of older primodia.

The patterns of expression of $L F Y / F L O$ documented for representatives of Bignonieae were, however, different from those reported for pea (Hofer et al., 1997). In early stages of leaf development in pea, $L F Y / F L O$ was strongly expressed in the distal portion of the leaf primordium, but not in the SAM. LFY/FLO were, however, expressed in the expanding leaf margins in later stages of development (Hofer et al., 1997). Expression of $L F Y / F L O$ was encountered in the flanks of the SAM and in the emerging leaf primordia in a wide range of angiosperms, including species belonging to several simple leaved genera (Vitis, Populus, Eucalyptus, Arabidopsis, Actinidia, Impatiens, Petunia and Nicotiana), and species belonging to compound-leaved genera (Pisum, Lycopersicon and Eschscholzia; Busch and Gleissberg, 2003). Among all species of Bignonieae studied, D. unguis-cati was the only species that presented a 
pattern of $L F Y / F L O$ expression that was similar to that identified in other angiosperms (Fig. 20B). In $B$. callistegioides, a simple-tendrilled species, transcripts were also detected in the stem, and tendril tips, region that in this species do not undergo ramification, indicating that the expression of $L F Y / F L O$ was not associated with blastozone activity and tendril ramification in this species, but possibly with the general growth of the leaf primordia. More importantly, all species of Bignonieae analyzed presented expression of $L F Y / F L O$ in the center of the SAM, different from what was previously documented for most other species of angiosperms.

The compound leaves of Eschscholzia and Pisum develop acropetally, but present different patterns of expression of $L F Y / F L O$. In particular, while EcFLO transcripts accumulated in the regions of the blastozone where leaflets were emerging, transcript of PEAFLO accumulated at the tip of the leaflet and tendril primordia in Pisum (Busch and Gleissberg, 2003). Compound leaves of tomato, on the other hand, develop basipetally which has led scientists to question whether there would be any association between major regulators, and the mode of leaf development (Hofer et al., 2001). More specifically, it was hypothesized that basipetal differentiation might be associated with the expression of $K N O X 1$, while acropetal differentiation might be associated with the expression of LFY/FLO (Hofer et al., 2001). However, further studies have shown that the patterns of expression of LFY/FLO in Eschscholzia were different from those of Pisum. In addition, expression of STM was detected during the development of leaf pinna in Eschscholzia but not in Pisum (Groot et al., 2005). Leaves of Bignonieae develop acropetally (Sousa-Baena et al., 2011). Furthermore, the species investigated in this study presented concomitant expression of $L F Y / F L O$ and STM during leaf development, which is more similar to the expression patterns of Eschscholzia than of Pisum. This data reinforces the hypothesis that the development of pea leaves might represent an exception within angiosperms. Indeed, the expression pattern of FLO in Bignonieae seems to be more similar to that of tomato, in which TOFL, the tomato FLO ortholog, is expressed in the SAM, stem vascular traces, axillary buds, and developing leaves, with higher expression in the leaf adaxial side and leaf margins (Molinero-Rosales et al., 1999). Even though leaf primordia of tomato and Bignonieae leaf differentiate in opposite ways (basipetal versus acropetal), the pattern of expression of $L F Y / F L O$ was similar in these taxa, making it unclear what the exact function 
of $L F Y / F L O$ in vegetative shoot tips is, and corroborating the hypothesis that mode of differentiation is not associated with the pattern of expression of individual genes.

In tomato, for instance, loss of the expression of $L F Y / F L O$ only leads to minor alterations in the leaf adult form even though $L F Y / F L O$ is expressed in the SAM and developing leaves (MolineroRosales et al., 1999). In Antirrhinum, on the other hand, FLO is not expressed in vegetative meristems, but FLO mutants have altered phyllotaxies (Carpenter et al., 1995). Furthermore, Nicotiana LFY/FLO transgenic plants present an altered organogenesis of leaves and lateral branches (Ahearn et al., 2001), while transgenic apples overexpressing $L F Y / F L O$ show shortened internodes and a larger number of leaves (Flachowsky et al., 2010). Finally, Eschscholzia and Nicotiana showed downregulation of LFY/ FLO at P0 (Kelly et al., 1995; Busch and Gleissberg, 2003).

In Nicotiana and Impatiens, LFY/FLO mRNA accumulates at the base of young primordia, in the flanks of the primordia. In Nicotiana, specifically, a ring of transcripts was identified in transverse sections of the shoot apex (Kelly et al., 1995; Pouteau et al., 1997), while an interruption of the mRNA signal was observed next to the developing primordia (Kelly et al., 1995). This ring pattern of mRNA accumulation, with gaps associated to the developing primordia, suggests that $L F Y / F L O$ may play a role in the process of separation of the leaf primordia from the peripheral zone of the SAM. (Pouteau et al., 1997). A similar pattern was observed in representatives of Bignonieae in which a ring with a higher accumulation of transcripts was detected in tranverse sections of A. buccinatorium (Figs. 19M-N). Furthermore, a complete lack of expression was identified in the boundaries between the leaf primordia and the SAM of D. unguis-cati and B. callistegioides, as well as between the leaflet primordia and the tendril lateral branches, and between the tendril lateral and primary branches of D. unguis-cati (Fig. 20F). These findings suggests that $L F Y / F L O$ may have a role in the division of leaves from the SAM, as well as in the separation of leaf parts within the leaf primordia of those taxa.

The data gathered here suggests that the interaction of $L F Y / F L O$ with cadastral genes may be responsible for the process that delimits compartments and creates boundaries between the developing organs and the meristem, as well as the processes that create boundaries between leaf parts in the leaf 
primordia of species of Bignonieae. Cadastral genes are known to inhibit cell proliferation in the regions that delimit organogenic sites; more precisely they delineate the expression of identity genes, preventing their ectopic expression (Weigel and Meyerowitz, 1994). A case in which cadastral genes interact with $L F Y / F L O$ causing modifications in leaf shape has been reported in Arabidopsis (Lee et al., 1997; Chae et al., 2008). More specifically, the rise of leaf serration in the leaves of the mutants overexpressing UNUSUAL FLORAL ORGANS (UFO) is dependent on the interactions between LFY and UFO in Arabidopsis (Lee et al., 1997; Chae et al., 2008). Since LFY/ FLO is a floral identity gene (Schultz and Haughn, 1991; Blasquez et al., 1997) and naturally interacts with other genes that control flower development, the interaction of $L F Y / F L O$ with $U F O$, as well as with other floral genes, might be important for compound leaf development.

\section{Conclusions}

The tendrils of pea are thought to either represent modified leaflets or extended rachises. However, the exact origin of these tendrils is still not completely understood. The anatomical and genetic data gathered in this study indicate that tendrils of representatives of the tribe Bignonieae are derived from a modified terminal leaflet. However, while branched tendrils retain leaflet characteristics, simple tendrils do not present anatomical features that resemble those of leaflets. Even though species with simple tendrils maintain a bilateral symmetry, the adaxial domain of those species does not present the marked expression of PHAN encountered in species with parted tendrils. Despite that, simple tendrils are also thought to have originated from leaflets, following the patterns encountered in its close relatives with parted tendrils. Following the heterochronic model proposed to explain leaf development in pea, it is possible that $B$. callistegioides may have gone less far in the developmental route defined by the heterochronic model, leading to a lack of leaflet characteristics in the tendrils of this species.

In representatives of Bignonieae, STM showed the expected expression pattern thus STM likely performs the same role in the development of leaves of representatives of Bignonieae than it does in other compound-leaved taxa. In Bignonieae species, $P H A N$ is always expressed in the adaxial domain of branched tendrils and throughout the whole organ in simple tendrils. The variation of the expression 
of PHAN according to tendril types seems to relate to the establishment of polarity. In Bignonieae, the expression of STM overlaps with that of PHAN, which agrees with the data that is currently available for other compound-leaved species (e.g., tomato), but disagrees with gene expression patterns found during pea leaf development. Pea leaves development is controlled by LFY/FLO instead of KNOX1, and in this species the expression pattern of KNOX1 is very similar to that seen in Arabidopsis, a simpleleaved species. Thus, the fact that tendrilled leaves of representatives of Bignonieae expressed KNOX1 during development, represents one more strong evidence that compound leaves exclusively controlled by $L E A F Y$, as the leaves encountered in the IRLC clade of peas, might be an exception among the angiosperms. Lastly, the patterns of expression of FLO encountered in Bignonieae suggest that this gene may be involved in partitioning the primordia from the SAM, a role that has been previously attributed to FLO in Nicotiana and Impatiens. Under this scenario, it is possible that the expression of FLO may be antagonized by cadastral genes during leaf development, with the concerted expression of these genes setting the boundaries of new organs that emerge from meristematic zones (i.e., SAM and blastozone).

Results from the present study greatly advanced our understanding on the function of STM, PHAN and FLO during the development of the tendrilled leaves in Bignonieae. However, the hypothesized function of those genes can only be confirmed through functional studies. In model plants, these analyses are usually performed by stable genetic transformations. However, the study of gene function is still challenging in non-model taxa. Virus induced gene silencing (VIGS), a relatively new technique to downregulate gene expression in plants, emerged as a powerful tool for functional analyses in non-model species. Initial experiments with VIGS in Dolichandra unguis-cati, utilizing a vector based on Tobacco Rattle Virus (TRV), indicate that species of Bignonieae may be amenable to gene silencing through VIGS (M. Sousa-Baena et al., unpubl. data). Furthermore, plant tissue culture and transformation protocols have also been established to representatives of the plant family Bignoniaceae (Nandwani et al., 1995, 1996; Aslam et al., 2009), providing us with a starting point for the development of protocols for stable genetic transformation in species of the Bignonieae. Only with information on the silencing of STM, PHAN and FLO in representatives of Bignonieae will we be able to confirm the hypothesized functions of STM, PHAN and FLO for the development of tendrilled leaves in Bignonieae. 


\section{LITERATURE CITED}

Ahearn, K.P., Johnson, H.A., Weigel, D., and Wagner, D.R. (2001). NFL1, a Nicotiana tabacum LEAFY-like gene, controls meristem initiation and floral structure. Plant Cell Physiology 42: $1130-1139$

Aida, M., Beis, D., Heidstra, R., Willensen, V., Blilou, I., Galinha, C., Nussaume, L., Noh, Y., Amasino, R., and Scheres, B. (2004). The PLETHORA genes mediate patterning of the Arabidopsis root stem cell niche. Cell 119: 109-120.

Angiosperm Phylogeny Group - A.P.G. (2009). An update of the angiosperm phylogeny group classification for the orders and families of flowering plants: APG III. Botanical Journal of the Linnean Society 161: 105-121.

Aslam, M., Singh, R., Anandhan, S., Pande, V., and Ahmed, Z. (2009). Development of a transformation protocol for Tecomella undulata (Smith) Seem from cotyledonary node explants. Scientia Horticulturae 121: 119-121.

Barkoulas, M., Galinha, C., Grigg, S.P., and Tsiantis, M. (2007). From genes to shape: regulatory interactions in leaf development. Current Opinion in Plant Biology 10: 660-666.

Bharathan, G., Goliber, T.E., Moore, C., Kessler, S., Pham, T., and Sinha, N.R. (2002). Homologies in leaf form inferred from KNOXI gene expression during development. Science 296: 1858-1860.

Blazquez, M.A., Soowal, L.N., Lee, I., and Weigel, D. (1997). LEAFY expression and flower initiation in Arabidopsis. Development 124: 3835-3844.

Blein, T., Pulido, A., Vialette-Guiraud, A., Nikovics, K., Morin, H., Hay, A., Johansen, E., Tsiantis, M., and Laufs, P. (2008). A conserved molecular framework for compound leaf development. Science 322: 1835-1839.

Bradley, D., Vincent, C., Carpenter, R., and Coen, E. (1996). Pathways for inflorescence and floral induction in Antirrhinum. Development 122: 1535-1544. 
Breuil-Broyer, S., Morel, P., de Almeida-Engler, J., Coustham, V., Negrutiu, I., and Trehin, C. (2004). High-resolution boundary analysis during Arabidopsis thaliana flower development. Plant Journal 38: 182-192.

Busch, A., and Gleissberg, S. (2003). EcFLO, a FLORICAULA-like gene from Eschscholzia californica is expressed during organogenesis at the vegetative shoot apex. Planta 217: 841-848.

Byrne, M.E., Barley, R., Curtis, M., Arroyo, J.M., Dunham, M., Hudson, A., and Martienssen, R.A. (2000). Asymmetric leaves1 mediates leaf patterning and stem cell function in Arabidopsis. Nature 408: 967-971.

Byrne, M.E., Simorowski, J., and Martienssen, R.A. (2002). Asymmetric Leaves1 reveals knox gene redundancy in Arabidopsis. Development 129: 1957-1965.

Carpenter, R., Copsey, L., Vincent, C., Doyle, S., Magrath, R., and Coen, E. (1995). Control of flower development and phyllotaxy by meristem identity genes in Antirrhinum. Plant Cell 7: 2001-2011

Chae, E., Tan, Q.K., Hill, T.A., and Irish, V.F. (2008). An Arabidopsis F-box protein acts as a transcriptional co-factor to regulate floral development. Development 135: 1235-1245.

Champagne, C., and Sinha, N.R. (2004). Compound leaves: equal to the sum of their parts? Development 131: 4401-4412.

Champagne, C.E.M., Goliber, T.E., Wojciechowski, M.F., Mei, R.W., Townsley, B.T., Wang, K., Paz, M.M., R., G., and Sinha, N.R. (2007). Compound leaf development and evolution in the legumes. The Plant Cell 19: 3315-3316.

Darwin, C. (1875). The movements and habits of climbing plants. 2d ed. John Murray, London. 118pp.

Davies, J.A. (2005). Mechanisms of morphogenesis: the creation of biological form. Elsevier Academic Press. 374pp.

DeMason, D.A., and Chetty, V.J. (2011). Interactions between Ga, Auxin, and Uni Expression Controlling 
Shoot Ontogeny, Leaf Morphogenesis, and Auxin Response in Pisum Sativum (Fabaceae): Or How the Uni-Tac Mutant Is Rescued. American Journal of Botany 98: 775-791.

Eshed, Y., Izhaki, A., Baum, S.F., Floyd, S.K., and Bowman, J.L. (2004). Asymmetric leaf development and blade expansion in Arabidopsis are mediated by $K A N A D I$ and $Y A B B Y$ activities. Development 131: 2997-3006.

Fischer, E., Theisen, I., and Lohmann, L.G. (2004). Bignoniaceae. In K. Kubitzki and J. W. Kadereit (eds.). The Families and Genera of Vascular Plants. VII. Dicotyledons. Lamiales (Except Acanthaceae including Avicenniaceae). Springer-Verlag, Heidelberg, pp. 9-38.

Flachowsky, H., Hättasch, C., Höfer, M., Peil, A., and Hanke, M.-V. (2010). Overexpression of LEAFY in apple leads to a columnar phenotype with shorter internodes. Planta 231: 251-263.

Garcês, H.M.P., and Sinha, N.R. (2009a). Fixing and sectioning tissue from the plant Kalanchö daigremontiana. Cold Spring Harbour Protocols; 2009; doi:10.1101/pdb.prot5301.

Garcês, H.M.P., and Sinha, N.R. (2009b). In situ hybridization in the plant Kalanchoë daigremontiana. Cold Spring Harbour Protocols; 2009; doi:10.1101/pdb.prot5302.

Gourlay, C.W., Hofer, J.M.I., and Ellis, T.H.N. (2000). Pea compound leaf architecture is regulated by interactions among the genes UNIFOLIOLATA, COCHLEATA, AFILA and TENDRIL-LESS. The Plant Cell 12: 1279-1294.

Groot, E.P., Sinha, N., and Gleissberg, S. (2005). Expression patterns of STM-like KNOX and Histone H4 genes in shoot development of the dissected-leaved basal eudicot plants Chelidonium majus and Eschscholzia californica (Papaveraceae). Plant Molecular Biology 58: 317-331.

Hagemann, W., and Gleissberg, S. (1996). Organogenetic capacity of leaves: the significance of marginal blastozones in angiosperms. Plant Systematics and Evolution 199: 121-152.

Hall, T.A. (1999). BioEdit: a user-friendly biological sequence alignment editor and analysis program for Windows 95/98/NT. Nucleic Acids Symposium Series 41:95-98. 
Hareven, D., Gutfinger, T., Parnis, A., Eshed, Y., and Lifschitz, E. (1996). The making of a compound leaf: genetic manipulation of leaf architecture in tomato. Cell 84: 735-744.

Harrison, C.J., and Langdale, J.A. (2006). A step by step guide to phylogeny reconstruction. The Plant Journal 45: 561-572.

Harrison, C.J., Corley, S.B., Moylan, E.C., Alexander, D.L., Scotland, R.W., and Langdale, J.A. (2005). Independent recruitment of a conserved developmental mechanism during leaf evolution. Nature 434: 509-514.

Hay, A., and Tsiantis, M. (2006). The genetic basis for differences in leaf form between Arabidopsis thaliana and its wild relative Cardamine hirsuta. Nature Genetics 38: 942-947.

Hempel, F.D., Weigel, D., Mandel, M.A., Ditta, G., Zambryski, P.C., Feldman, L.J., and Yanofsky, M.F. (1997) Floral determination and expression of floral regulatory genes in Arabidopsis. Development 124: 3845-3853.

Hind, D.J.N. (2007). Asteraceae. In: K. Kubitzki, J.W. Kadereit, and C. Jeffrey (eds.). The Families and Genera of Vascular Plants. VIII. Eudicots. Asterales. Springer-Verlag, Heidelberg, pp. 90-122.

Hofer, J., Turner, L., Moreau, C., Ambrose, M., Isaac, P., Butcher, S., Weller, J., Dupin, A., Dalmais, M., Le Signor, C., Bendahmane, A., and Ellis, N. (2009). Tendril-less regulates tendril formation in pea leaves. Plant Cell 21: 420-428.

Hofer, J.M.I., Gourlay, C.W., Michael, A., and Ellis, T.H.N. (2001). Expression of a class 1 Knotted1like homeobox gene is down-regulated in pea compound leaf primordia. Plant Molecular Biology 45: 387-398.

Hofer, J.M.I., Turner, L., Hellens, R., Ambrose, M., Matthews, P., Michael, A., and Ellis, T.H.N. (1997). UNIFOLIOLATA regulates leaf and flower morphogenesis in pea. Current Biology 7: 581-587.

Husbands, A.Y., Chitwood, D.H., Plavskin, Y., and Timmermans, M.C.P. (2009). Signals and 
prepatterns: new insights into organ polarity in plants. Genes \& Development 23: 1986-1997.

Iwakawa, H., Iwasaki, M., Kojima, S., Ueno, Y., Soma, T., Tanaka, H., Semiarti, E., Machida, Y., and Machida, C. (2007). Expression of the ASYMMETRIC LEAVES2 gene in the adaxial domain of Arabidopsis leaves represses cell proliferation in this domain and is critical for the development of properly expanded leaves. The Plant Journal 51: 173-184.

Kadereit, J.W. (1993). Papaveraceae. In: K. Kubitzki, J.G. Rohwer, and V. Bittrich (eds.). The Families and Genera of Vascular Plants. II. Dicotyledons. Magnoliid, Hamamelid and Caryophyllid Families. Springer-Verlag, Heidelberg, pp. 494-505.

Kelly, A.J., Bonnlander, M.B., and Meeks-Wagner, D.R. (1995). NFL, the tobacco homolog of FLORICAULA and LEAFY is transcriptionally expressed in both vegetative and floral meristems. The Plant Cell 7: 225-234.

Kidner, C.A., and Timmermans, M.C.P. (2007). Mixing and matching pathways in leaf polarity. Current Opinion in Plant Biology 10: 13-20.

Kim, M., McCormick, S., Timmermans, M., and Sinha, N.R. (2003a). The expression domain of PHANTASTICA determines leaflet placement in compound leaves. Nature 424: 438-443.

Kim, M., Pham, T., Hamidi, A., McCormick, S., Kuzoff, R., and Sinha, N.R. (2003b). Reduced leaf complexity in tomato wiry mutants suggests a role for PHAN and $K N O X$ genes in generating compound leaves. Development 130: 4405-4415.

Koltai, H., and Bird, D.M. (2000). Epistatic repression of PHANTASTICA and class 1 KNOTTED genes is uncoupled in tomato. The Plant Journal 22: 455-459.

Kramer E. M., and Hall, J.C. (2005). Evolutionary dynamics of genes controlling floral development. Current Opinion in Plant Biology 8:13-18.

Lee, I.,Wolfe, D.S., Nilsson, O., and Weigel, D. (1997). A $L E A F Y$ co-regulator encoded by $U N U S U A L$ FLORAL ORGANS. Current Biology 7: 95-104. 
Lincoln, C., Long, J., Yamaguchi, J., Serikawa, K., and Hake, S. (1994). A knottedl-like homeobox gene in Arabidopsis is expressed in the vegetative meristem and dramatically alters leaf morphology when overexpressed in transgenic plants. The Plant Cell 6: 1859-1876.

Lohmann, L.G. (2003). Phylogeny, classification, morphological diversification and biogeography of Bignonieae (Bignoniaceae, Lamiales). Ph.D. Dissertation. University of Missouri-St. Louis, St. Louis, Missouri, USA.

Lohmann, L.G. (2004). Bignoniaceae. In: N. Smith, S.A. Mori, A. Henderson, D.W. Stevenson, and S. V. Heald (eds.), Flowering Plants of the Neotropics. Princeton University Press and the New York Botanical Garden, Princeton, pp. 51-53.

Lohmann, L.G. (2006). Untangling the phylogeny of neotropical lianas (Bignonieae, Bignoniaceae). Americam Journal of Botany 93: 304-318.

Lohmann, L.G. (2006). Untangling the phylogeny of neotropical lianas (Bignonieae, Bignoniaceae). Americam Journal of Botany 93: 304-318.

Lohmann, L.G. (2011). A new generic classification of Bignonieae (Bignoniaceae) based on molecular phylogenetic data and morphological synapomorphies. Annals of the Missouri Botanical Garden. (In press).

Lohmann, L.G., Stevens, P.F., and Kellogg, E.A. (2011). Twists in the phylogeny of Neotropical lianas (Bignonieae, Bignoniaceae): insights from morphology and molecules. Systematic Botany. (In press).

Long, J.A., Moan, E.I., Medford, J.I., and Barton, M.K. (1996). A member of the KNOTTED class of homeodomain proteins encoded by the STM gene of Arabidopsis. Nature 379: 66-69.

Lu, B., Villani, P.J., Watson, J.C., DeMason, D.A., and Cooke, T.J. (1996). The control of pinna morphology in wildtype and mutant leaves of the garden pea (Pisum sativum L.). International Journal of Plant Sciences 157: 659-673. 
Maizel, A., Busch, M.A., Tanahashi, T., Perkovic, J., Kato, M., Hasebe, M., and Weigel, D. (2005). The floral regulator $L E A F Y$ evolves by substitutions in the DNA binding domain. Science 308: 260-263.

McConnell, J.R., Emery, J., Eshed, Y., Bao, N., Bowman, J., and Barton, M.K. (2001). Role of PHABULOSA and PHAVOLUTA in determining radial patterning in shoots. Nature 411: 709-713.

McHale, N.A., and Koning, R.E. (2004). PHANTASTICA regulates development of the adaxial mesophyll in Nicotiana leaves. The Plant Cell 16: 1251-1262.

Molinero-Rosales, N., Jamilena, M., Zurita, S., Gomez, P., Capel, J., and Lozano, R. (1999). FALSIFLORA, the tomato orthologue of FLORICAULA and LEAFY, controls flowering time and floral meristem identity. Plant Journal 20: 685-693.

Nandwani, D., Mathur, N., and Ramawat, K.G. (1995). In-vitro shoot multiplication from cotyledonary node explants of Tecomella undulata. Gartenbauwissenschaft 60: 65-68.

Nandwani, D., Sharma, R., and Ramawat, K.G. (1996). High frequency regeneration in callus cultures of a tree Tecomella undulata. Gartenbauwissenschaft 61: 147-150.

Nishii, K., Moller, M., Kidner, C., Spada, A., Mantegazza, R., Wang, C.N., and Nagata, T. (2010). A complex case of simple leaves: indeterminate leaves co-express ARP and KNOX1 genes. Development Genes and Evolution 220: 25-40.

O’Brien, T.P., Feder, N., and McCully, M.E. (1964). Polychromatic staining of plant cell walls by Toluidine blue O. Protoplasma 59: 368-373.

Parnis, A., Cohen, O., Gutfinger, T., Hareven, D., Zamir, D., and Lifschitz, E. (1997). The dominant developmental mutants of tomato, Mouse-ear and Curl, are associated with distinct modes of abnormal transcriptional regulation of a Knotted gene. The Plant Cell Online 9: 2143-2158.

Poethig, R.S. (1997). Leaf morphogenesis in flowering plants. The Plant Cell 9: 1077-1087. 
Pouteau, S., Nicholls, D., Tooke, F., Coen, E., and Battey, N. (1997). The induction and maintenance of flowering in Impatiens. Development 124: 3343-3351.

Putz, F.E., and Holbrook, N.M. (1991). Biomechanical studies of vines. Pp. 73-97 in F. E. Putz \& H. A. Mooney (eds.), The Biology of Vines. Cambridge University Press, New York.

Schmid, R. (1982). The terminology and classification of steles: historical perspective and the outlines of a system. The Botanical Review 48: 817-931.

Schultz, E.A., and Haughn, G.W. (1991). LEAFY, a homeotic gene that regulates inflorescence development in Arabidopsis. The Plant Cell 3: 771-781.

Semiarti, E., Ueno, Y., Tsukaya, H., Iwakawa, H., Machida, C., and Machida, Y. (2001). The ASYMMETRIC LEAVES2 gene of Arabidopsis thaliana regulates formation of asymmetric lamina, establishment of venation and repression of meristem-related homeobox genes in leaves. Development 128: 1771-1783.

Sinha, N.R. (1999). Leaf development in angiosperms. Annual Review of Plant Physiology 50: 419446.

Souer, E., van der Krol, A., Kloos, D., Spelt, C., Bliek, M., Mol, J., and Koes, R. (1998). Genetic control of branching pattern and floral identity during Petunia inflorescence development. Development 125: 733-742.

Sousa-Baena, M.S., Sinha, N., and Lohmann, L.G. (2011). Evolution and development of tendrils in Bignonieae (Bignoniaceae, Lamiales). Annals of the Missouri Botanical Garden. (under review).

Sun, Y., Zhou, Q., Zhang, W., Fu, Y. and Huang, H. (2002). ASYMMETRIC LEAVES1, an Arabidopsis gene that is involved in the control of cell differentiation in leaves. Planta 214: 694-702.

Tamura, K., Peterson, D., Peterson, N., Stecher, G., Nei, M., and Kumar, S. (2011). MEGA5: Molecular evolutionary genetics analysis using maximum likelihood, evolutionary distance, and 
maximum parsimony methods. Molecular Biology and Evolution (In Press).

Tamura, M. (1993). Ranunculaceae. In: K. Kubitzki, J.G. Rohwer, and V. Bittrich (eds.). The Families and Genera of Vascular Plants. II. Dicotyledons. Magnoliid, Hamamelid and Caryophyllid Families. Springer-Verlag, Heidelberg, pp. 563-583.

Tattersall, A.D., Turner, L., Knox, M.R., Ambrose, M.J., Ellis, T.H.N., and Hofer, J.M.I. (2005). The mutant crispa reveals multiple roles for PHANTASTICA in pea compound leaf development. The Cell 17: 1046-1060.

Timmermans, M.C.P., Hudson, A., Becraft, P.W., and Nelson, T. (1999). ROUGH SHEATH2: A Myb protein that represses knox homeobox genes in maize lateral organ primordia. Science 284: 151 153.

Tsiantis, M., Schneeberger, R., Golz, J. F., Freeling, M., and Langdale, J. A. (1999). The Maize rough sheath2 gene and leaf development programs in monocot and dicot plants. Science 284: 154-156.

Tsukaya, H. (2010). Leaf development and evolution. Journal of Plant Research 123: 3-6.

Uchida, N., Townsley, B., Chung, K.-H., and Sinha, N.R.(2007). Regulation of SHOOTMERISTEMLESS genes via an upstream-conserved noncoding sequence coordinates leaf development. Proceedings of the National Academy of Sciences 104 15953-15958.

Villani, P.J., and DeMason, D.A. (1997). Roles of the $A f$ and $T l$ genes in pea leaf morphogenesis: characterization of the double mutant (afaf/tltl). American Journal of Botany 84: 1323-1336.

Waites, R., and Hudson, A. (1995). phantastica: a gene required for dorsoventrality of leaves in Antirrhinum majus. Development 121: 2143-2154.

Waites, R., Selvadurai, H.R.N., Oliver, I.R., and Hudson, A. (1998). The PHANTASTICA gene encodes a MYB transcription factor involved in growth and dorsoventrality of lateral organs in Antirrhinum. Cell 93: 779-789. 
Weigel, D. and Meyerowitz, E. M. (1994). The ABCs of floral homeotic genes. Cell 78: 203-209.

Wilken, D. H. (2004). Polemoniaceae. In: K. Kubitzki (ed.). The Families and Genera of Vascular Plants. VI. Dicotyledons. Celastrales, Oxalidales, Rosales, Cornales, Ericales. Springer-Verlag, Heidelberg, pp. 300-312. 


\section{Supplemental data}


Supplemental figure 1. SHOOTMERISTEMLESS nucleotide alignment.

AbSTM
DuSTM
BcSTM
invaginata
hirzina
SrSTM
SsSTM
SHOOTMERISTEMLESS
BrSTM
BnSTM
ChSTM
KNAT1
KNAT2
LeT6
TKn1
POTH1
TobH1
PhSTM
InSTM
TmSTM
WsSTM
PsSTM
EeSTM
Sbh1
PsKn1
MtKNOX6
MtKNOX1
OSH1
HvKnox3
rs1
Kn1
AgaveKNOX1
EgKNOX1
KNAT7
KNAT3

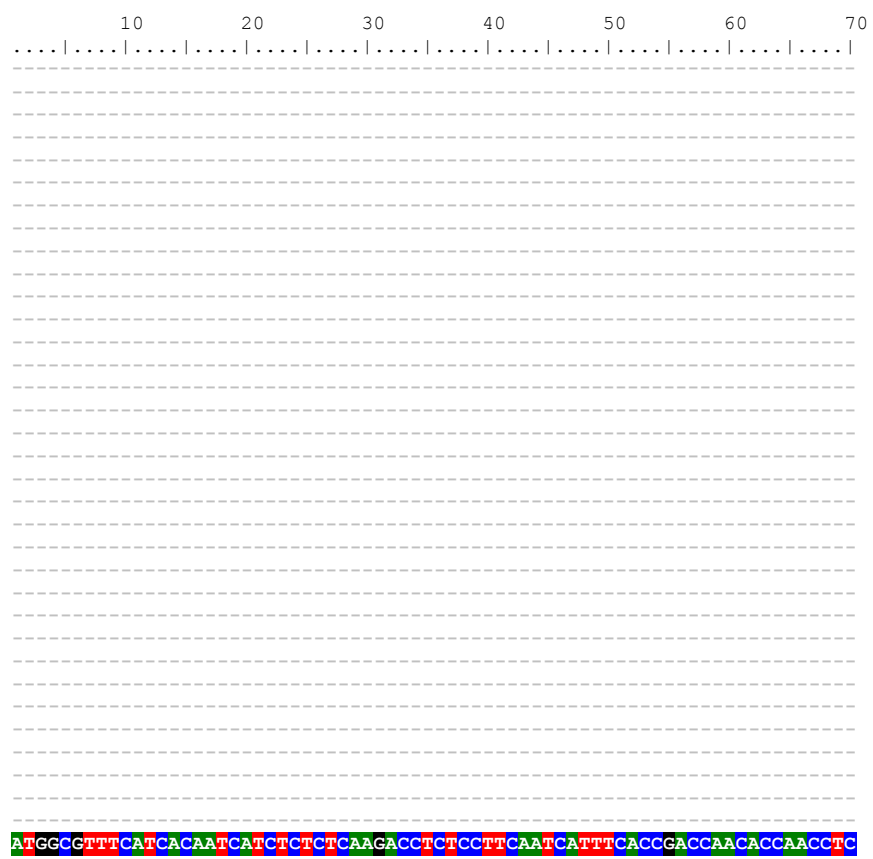

AbSTM
DuSTM
BcSTM
invaginata
hirzina
SrSTM
SsSTM
SHOOTMERISTEMLESS
BrSTM
BnSTM
ChSTM
KNAT1
KNAT2
LeT6
TKn1
POTH1
TobH1
PhSTM
InSTM
TmSTM
WsSTM
PsSTM
EeSTM
Sbh1
PsKn1
MtKNOX6
MtKNOX1
OSH1
HvKnOx3
rs1
Kn1
AgaveKNox1
EgKNOX1
KNAT7
KNAT3

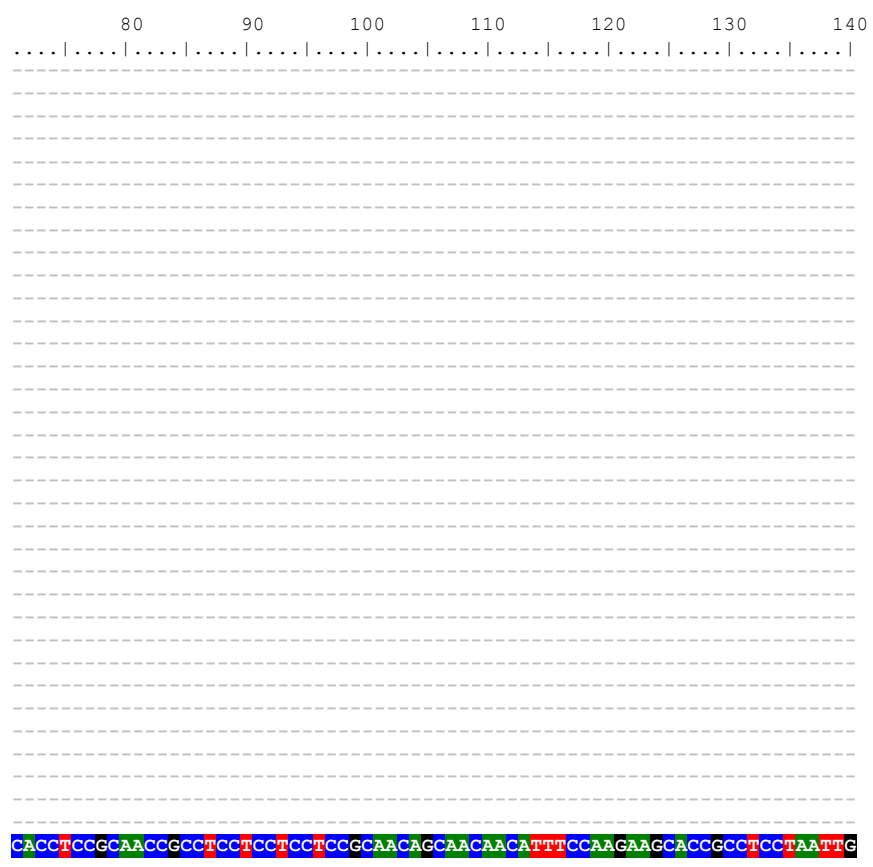




AbSTM
DuSTM
BcSTM
invaginata
hirzina
SrSTM
SsSTM
SHOOTMERISTEMLESS
BrSTM
BnSTM
ChSTM
KNAT1
KNAT2
LeT6
TKn1
POTH1
TobH1
PhSTM
InSTM
TmSTM
WsSTM
PsSTM
EeSTM
Sbh1
PsKn1
MtKNOX6
MtKNOX1
OSH1
HvKnox3
rs1
Kn1
AgaveKNox1
EgKNOX1
KNAT7
KNAT3

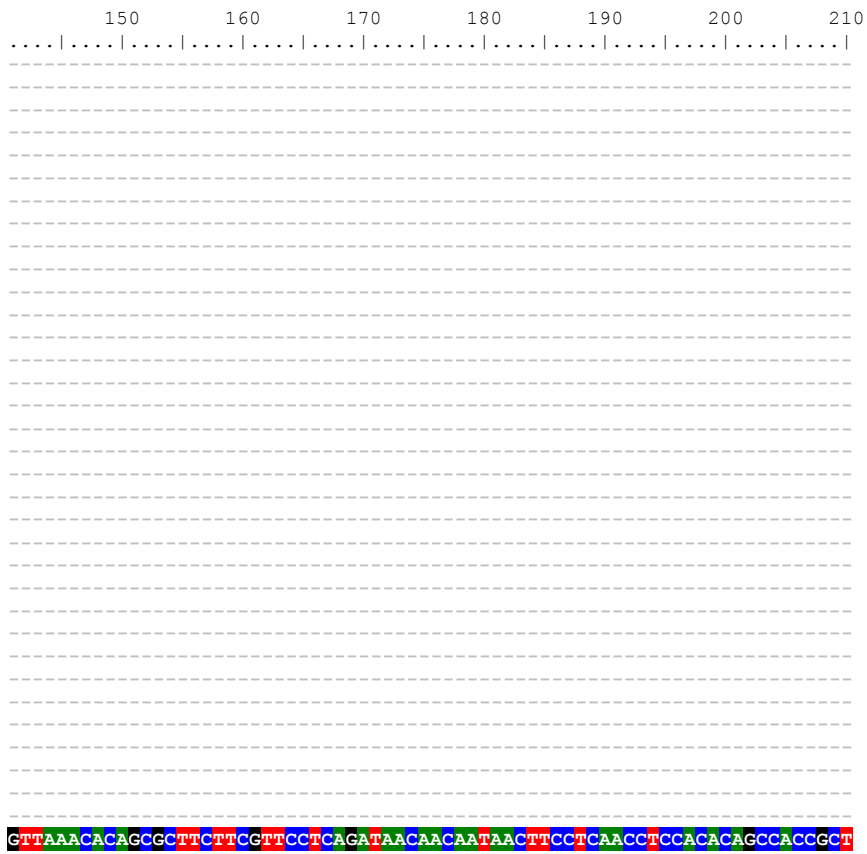

AbSTM

DuSTM

invaginata

hirzina

SrSTM

SHOOTMERISTEMLESS

BrSTM

BnSTM

ChSTM

KNAT1

KNAT2

LeT6
TKn1

POTH1

TobH1

PhSTM

InSTM

TmSTM

WSSTM

PsSTM

Sbh1

PsKn1

MtKNOX6

MtKNox

OSH1

HvKnox3

rs1
Kn1

AgaveKNox1

EgKNOX1

KNAT7

GTTAAACACAGCGCTTCTTCGTTCCTCAGATAACAACAATAACTTCCTCAACCTCCACACAGCCACCGC

KNAT3

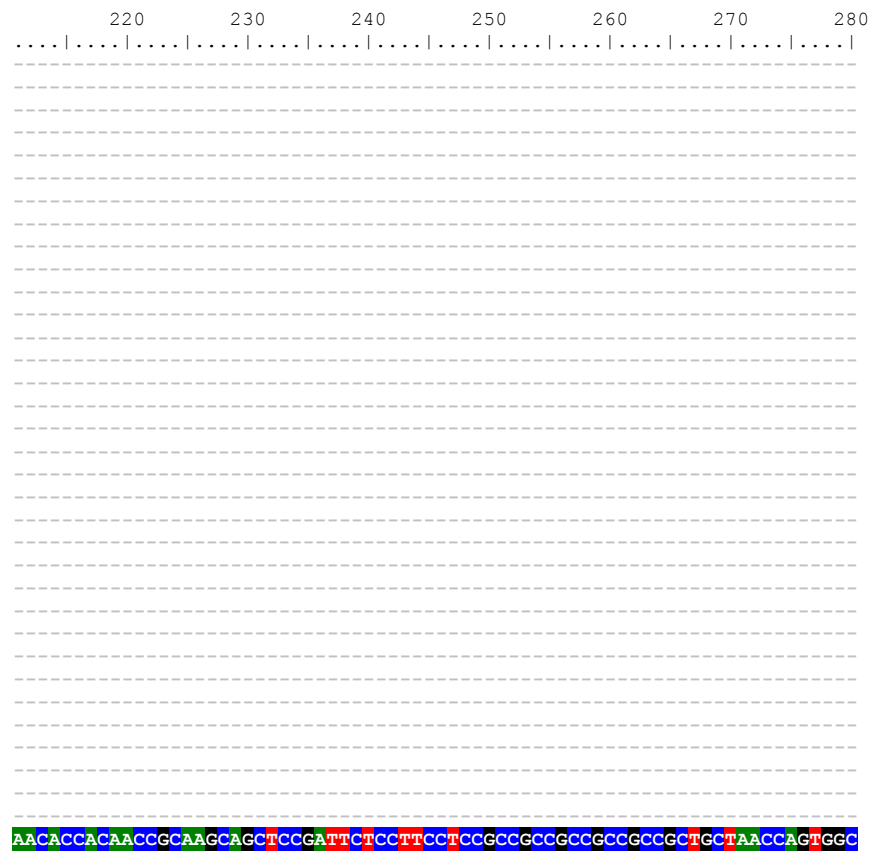



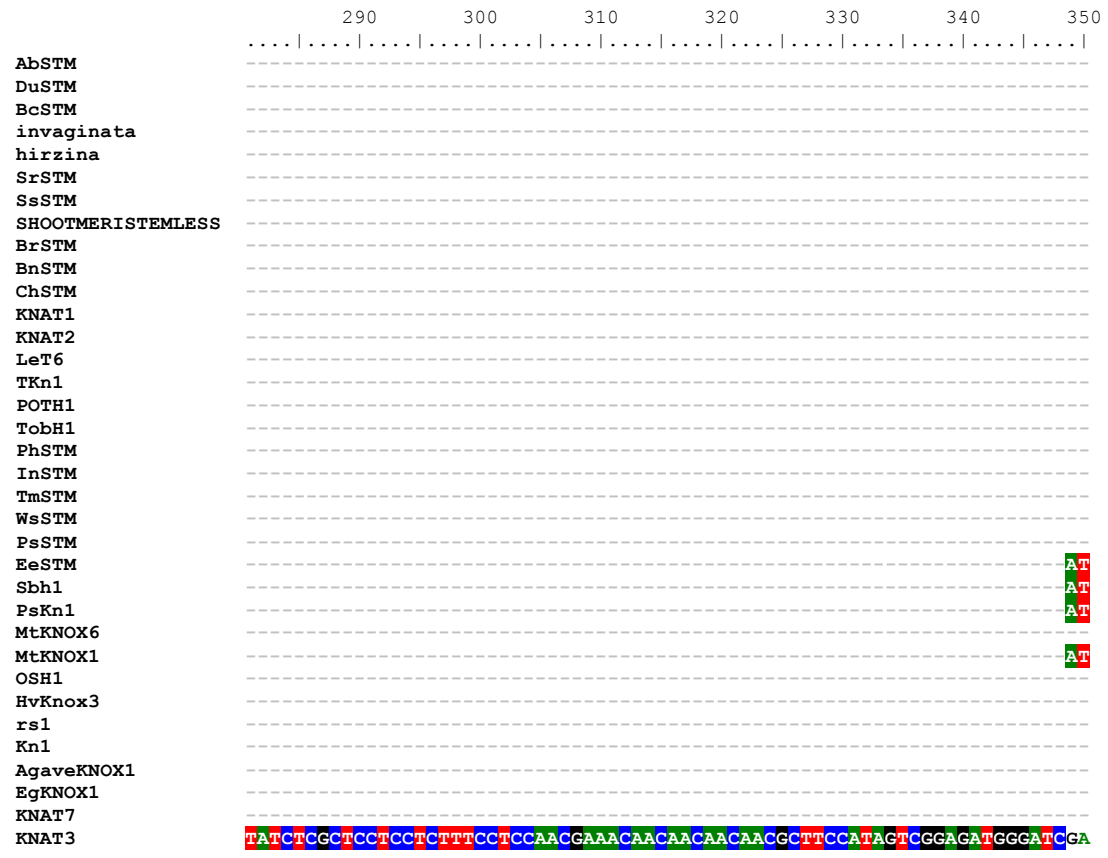

AbSTM

BuSTM

invaginata

hirzina

SrSTM

SHOOTMERISTEMLESS

BrSTM

BnSTM

KNAT1

KNAT2

LeT 6

TKn1

POTH

TobH 1

PhSTM

InSTM

WsSTM

PSSTM

EeSTM

Sbh1

PTKNox6

MtKNOX

MtKNOX

HvKnox 3

rs 1

Kn1

AgaveKNOX

EgKNoX1

KNAT7

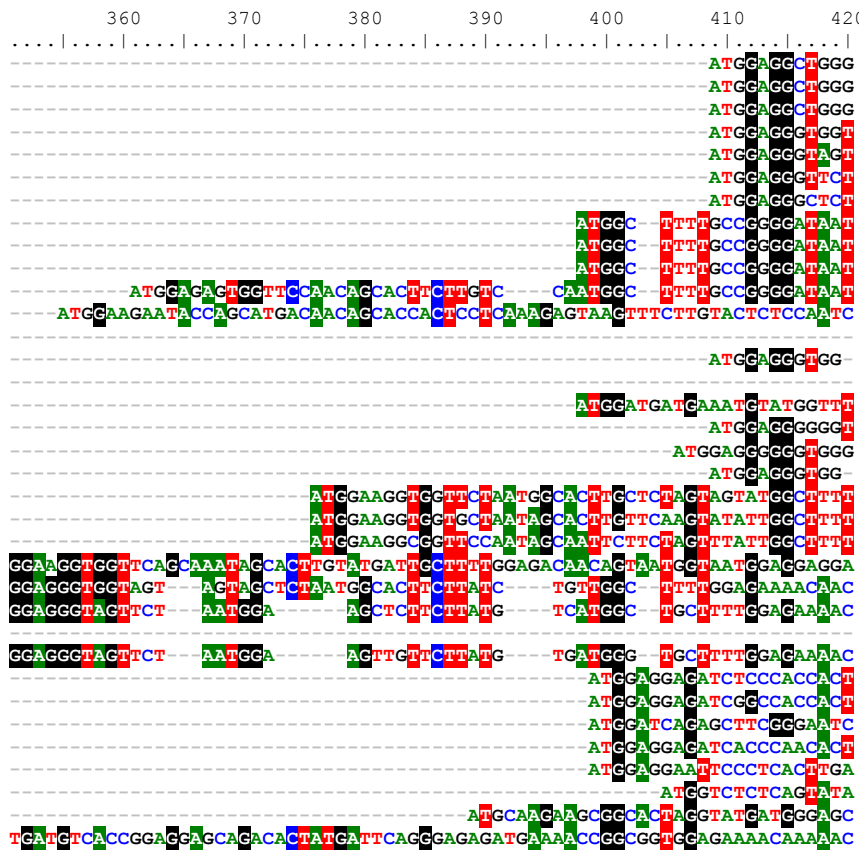




AbSTM
DuSTM
BcSTM
invaginata
hirzina
SrSTM
SsSTM
SHOOTMERISTEMLESS
BrSTM
BnSTM
ChSTM
KNAT1
KNAT2
LeT6
TKn1
POTH1
TobH1
PhSTM
InSTM
TmSTM
WsSTM
PsSTM
EeSTM
Sbh1
PsKn1
MtKNOX6
MtKNOX1
OSH1
HvKnox3
rs1
Kn1
AgaveKNox1
EgKNOX1
KNAT7
KNAT3
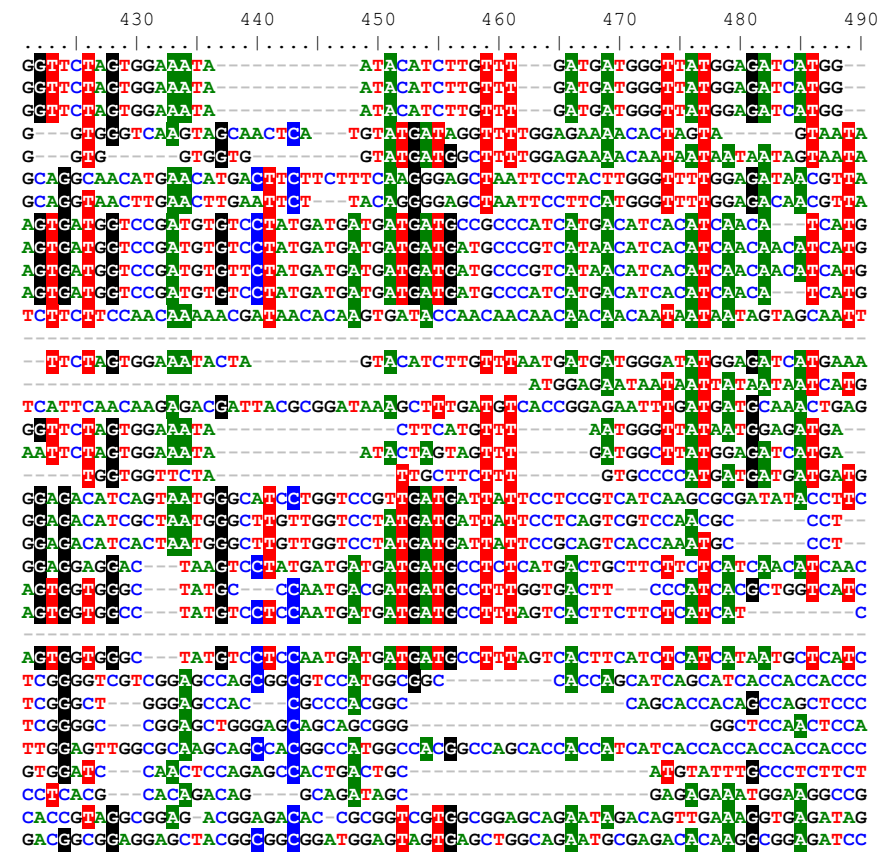

AbSTM
DuSTM
BcSTM
invaginata
hirzina
SrSTM
SsSTM
SHOOTMERISTEMLESS
BrSTM
BnSTM
ChSTM
KNAT1
KNAT2
LeT6
TKn1
POTH1
TobH1
PhSTM
InSTM
TmSTM
WsSTM
PsSTM
EeSTM
Sbh1
PsKn1
MtKNOX6
MtKNOX1
OSH1
HvKnOx3
rs1
Kn1
AgaveKNox1
EgKNOX1
KNAT7
KNAT3

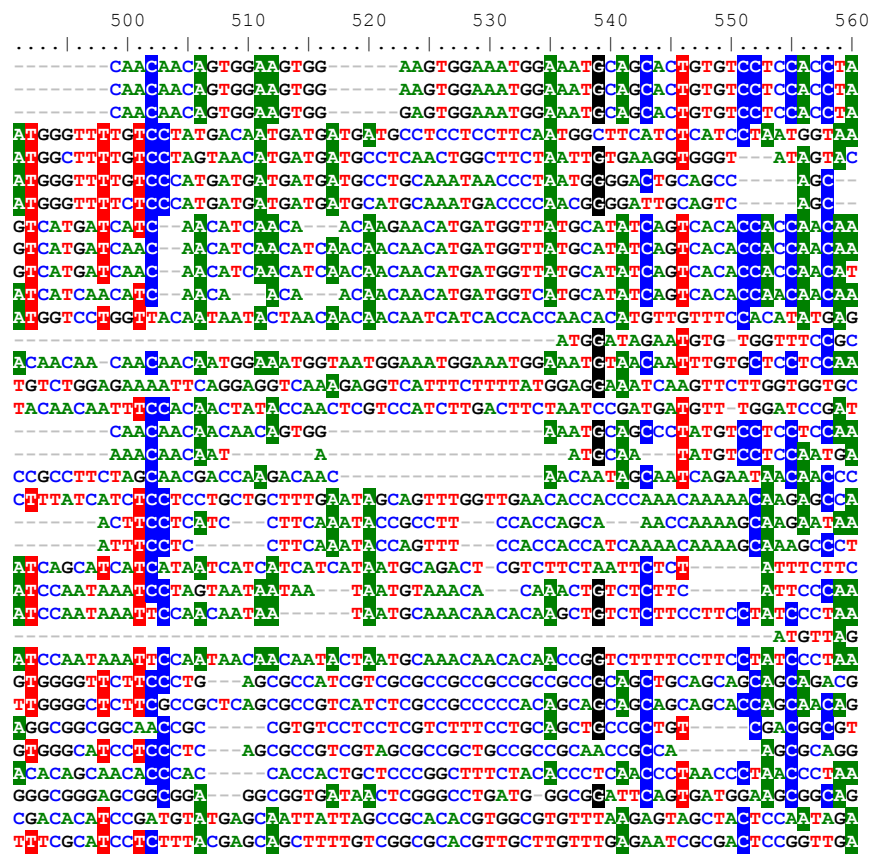




AbSTM
DuSTM
BCSTM
invaginata
hirzina
SrSTM
SsSTM
SHOOTMERISTEMLESS
BrSTM
BnSTM
ChSTM
KNAT1
KNAT2
LeT6
TKn1
POTH1
TobH1
PhSTM
InSTM
TmSTM
WsSTM
PsSTM
EeSTM
Sbh1
PsKn1
MtKNOX6
MtKNOX1
OSH1
HvKnOx3
rs1
Kn1
AgaveKNox1
EgKNOX1
KNAT7
KNAT3

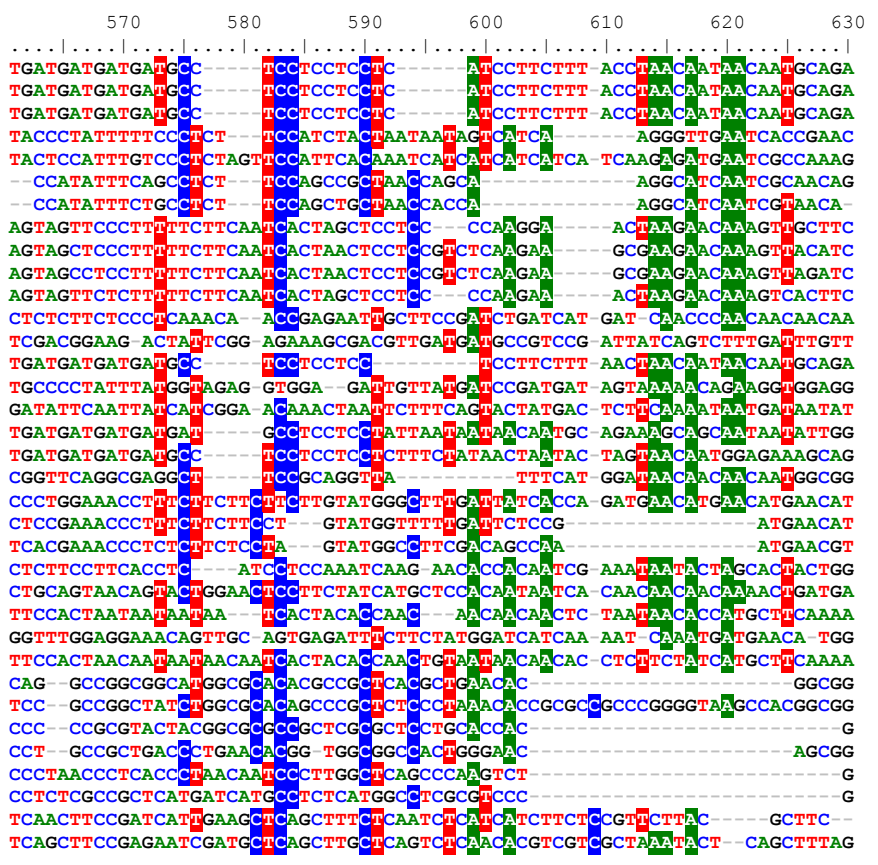

AbSTM
DuSTM
BcSTM
invaginata
hirzina
SrSTM
SsSTM
SHOOTMERISTEMLESS
BrSTM
BnSTM
ChSTM
KNAT1
KNAT2
LeT6
TKn1
POTH1
TobH1
PhSTM
InSTM
TmSTM
WsSTM
PsSTM
EeSTM
Sbh1
PsKn1
MtKNOX6
MtKNOX1
OSH1
HvKnOx3
rs1
Kn1
AgaveKNox1
EgKNOX1
KNAT7
KNAT3

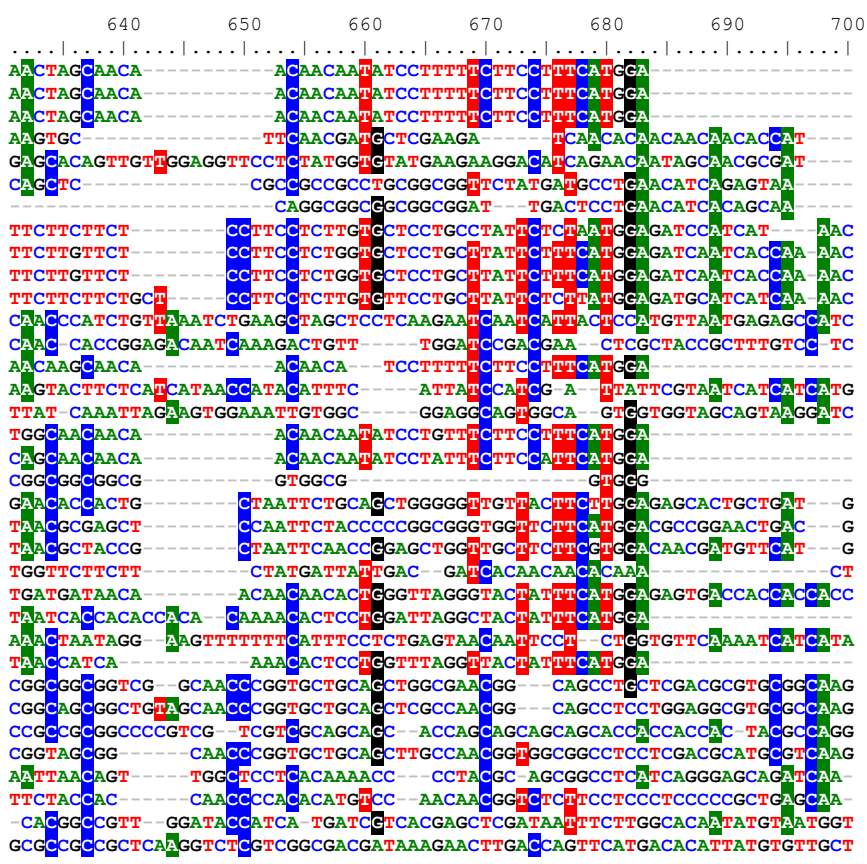




AbSTM
DuSTM
BCSTM
invaginata
hirzina
SrSTM
SsSTM
SHOOTMERISTEMLESS
BrSTM
BnSTM
ChSTM
KNAT1
KNAT2
LeT6
TKn1
POTH1
TobH1
PhSTM
InSTM
TMSTM
WSSTM
PsSTM
EeSTM
Sbh1
PsKn1
MtKNOX6
MtKNOX1
OSH1
HVKnOx3
rs1
Kn1
AgaveKNOX1
EgKNOX1
KNAT7
KNAT3

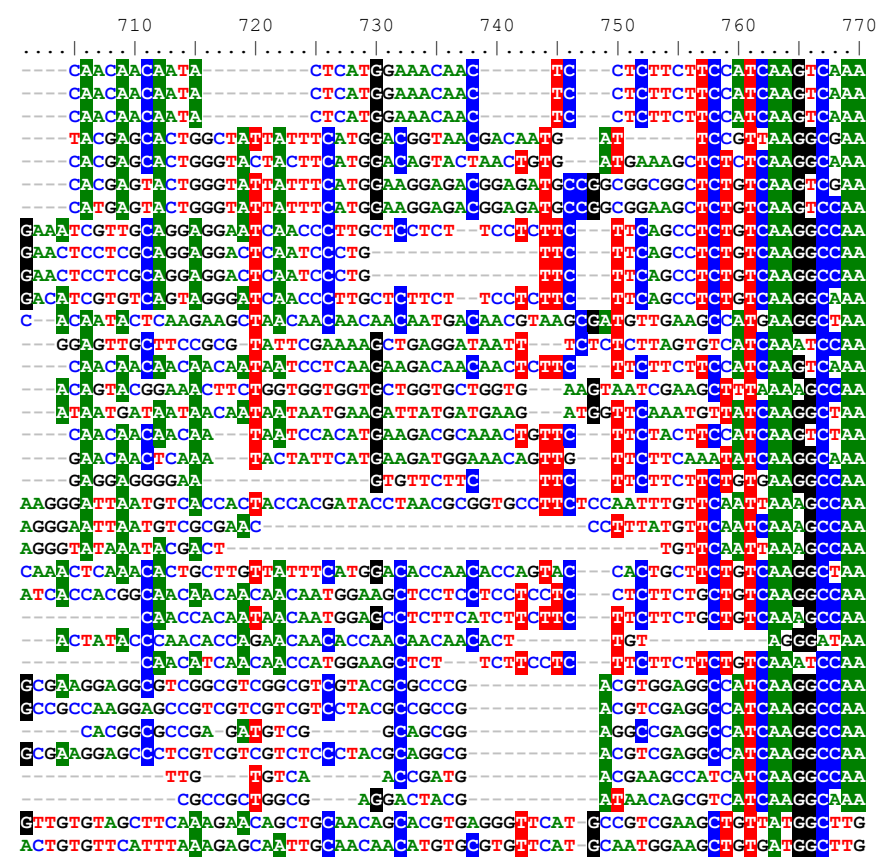

AbSTM
DuSTM
BcSTM
invaginata
hirzina
SrSTM
SsSTM
SHOOTMERISTEMLESS
BrSTM
BnSTM
ChSTM
KNAT1
KNAT2
LeT6
TKn1
POTH1
TobH1
PhSTM
InSTM
TmSTM
WsSTM
PsSTM
EeSTM
Sbh1
PsKn1
MtKNOX6
MtKNOX1
OSH1
HvKnOx3
rs1
Kn1
AgaveKNox1
EgKNOX1
KNAT7
KNAT3

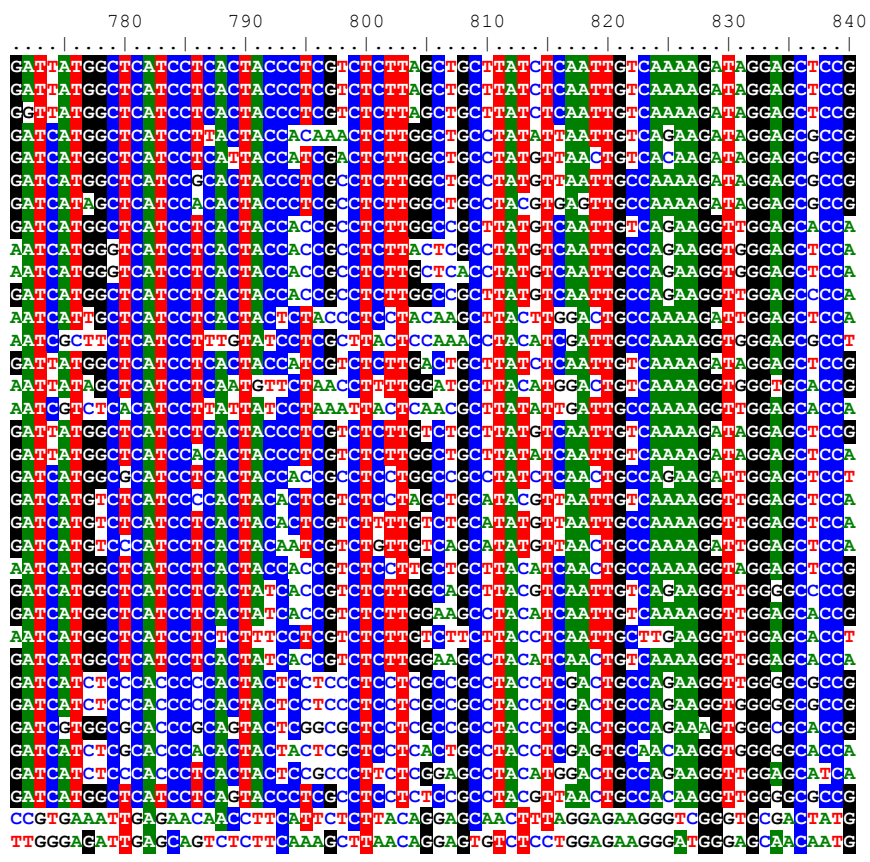




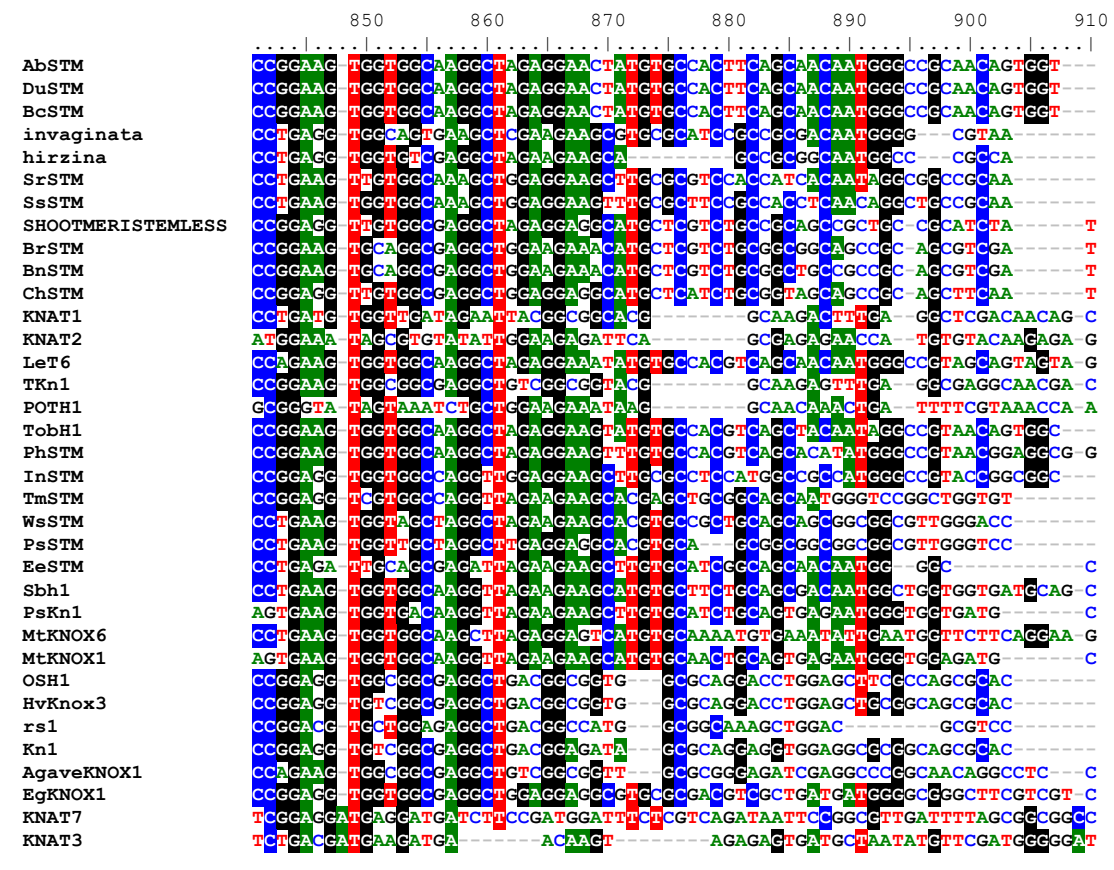

AbSTM
DuSTM
BCSTM
invaginata
hirzina
SrSTM
SsSTM
SHOOTMERISTEMLESS
BrSTM
BnSTM
ChSTM
KNAT1
KNAT2
LeT6
TKn1
POTH1
TobH1
PhSTM
InSTM
TmSTM
WsSTM
PsSTM
EeSTM
Sbh1
PsKn1
MtKNOX6
MtKNOX1
OSH1
HvKnOx3
rs1
Kn1
AgaveKNox1
EgKNOX1
KNAT7
KNAT3

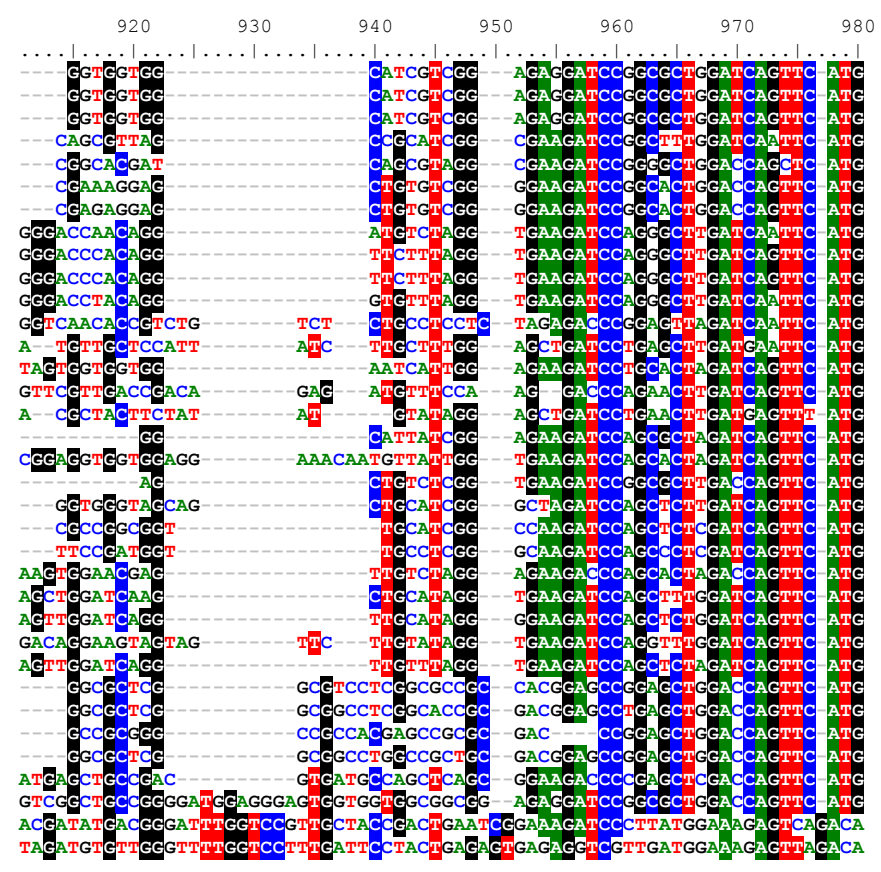




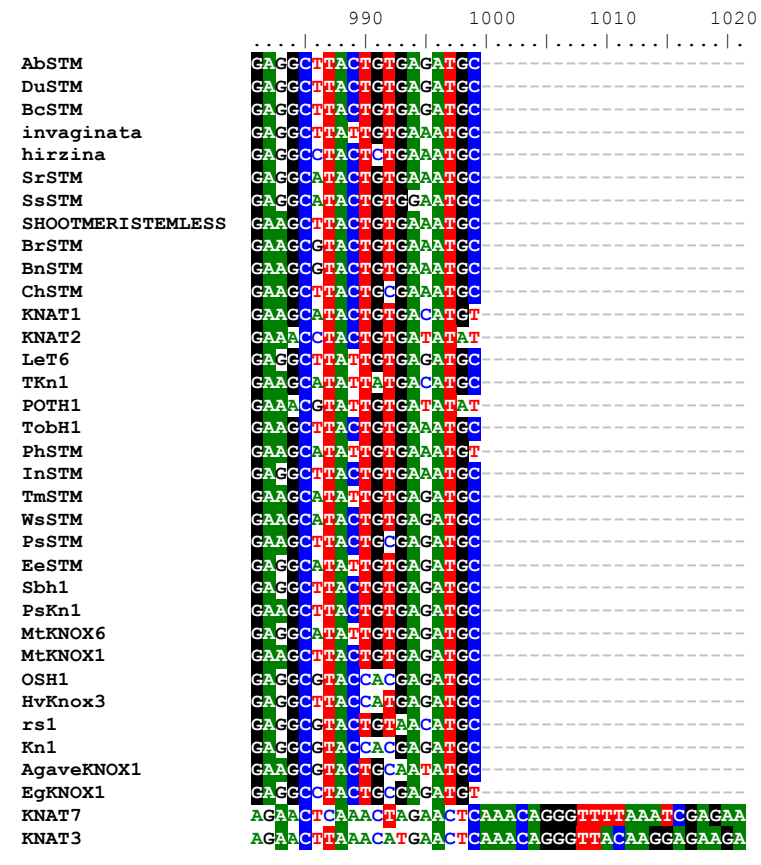


Supplemental figure 2. Deduced amino acid sequence alignment of SHOOTMERISTEMLESS orthologs used to reconstruct the phylogeny of STM. The KNOX domain is indicated by a solid black line.

AbSTM
DuSTM
BcSTM
invaginata
hirzina
SrSTM
SsSTM
SHOOTMERISTEMLESS
BrSTM
BnSTM
ChSTM
KNAT1
KNAT2
LeT6
TKn1
POTH1
TobH1
PhSTM
InSTM
TmSTM
WsSTM
PsSTM
EeSTM
Sbh1
PsKn1
MtKNOX6
MtKNOX1
OSH1
HvKnox3
rs1
Kn1
AgaveKNOX1
EgKNOX1
KNAT7
KNAT3

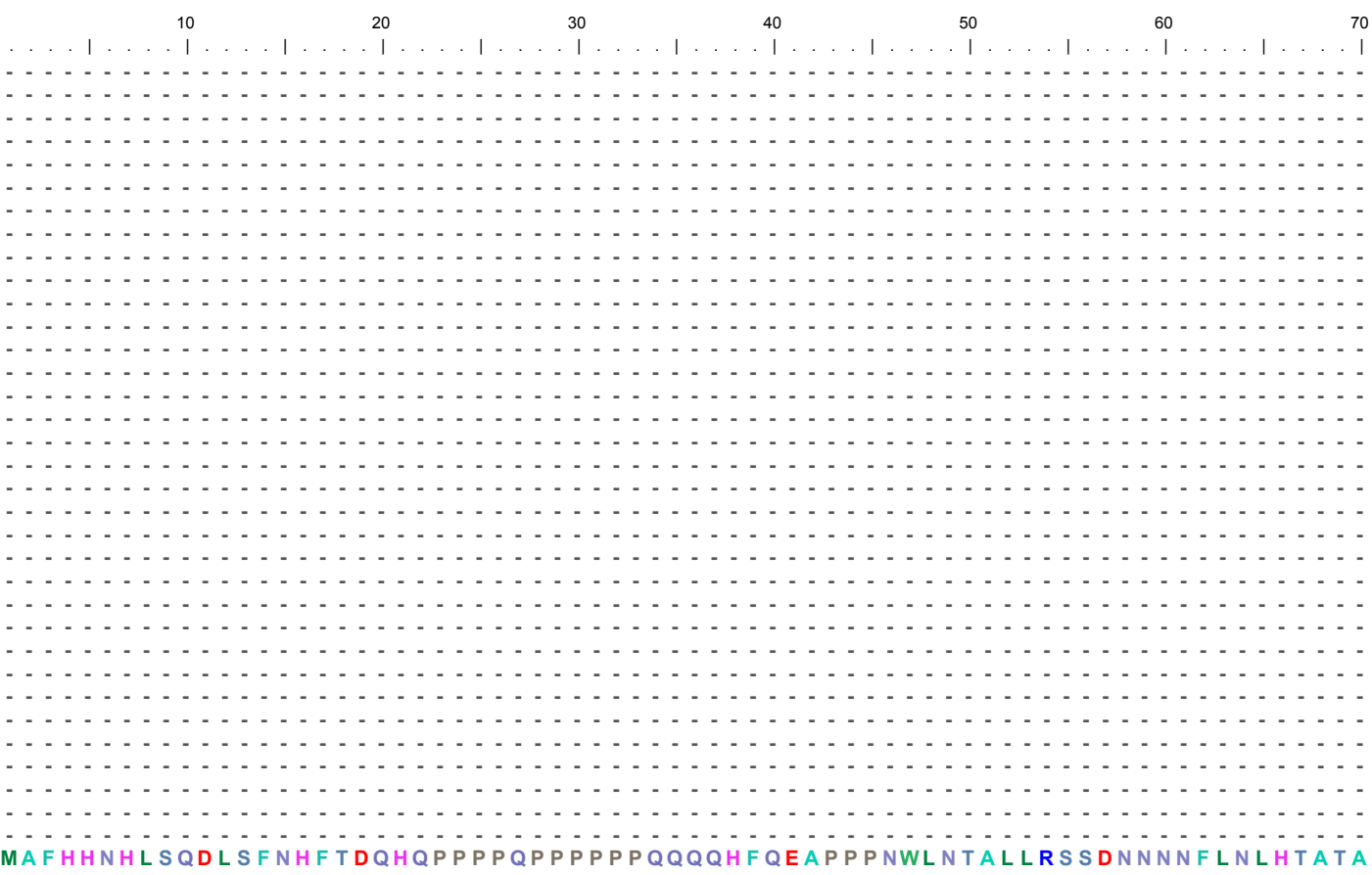

AbSTM
DuSTM
BcSTM
invaginata
hirzina
SrSTM
SsSTM
SHOOTMERISTEMLESS
BrSTM
BnSTM
ChSTM
KNAT1
KNAT2
LeT6
TKn1
POTH1
TobH1
PhSTM
InSTM
TmSTM
WsSTM
PsSTM
EeSTM
Sbh1
PsKn1
MtKNOX6
MtKNOX1
OSH1
HvKnox3
rs1
Kn1
AgaveKNOX1
EgKNOX1
KNAT7
KNAT3

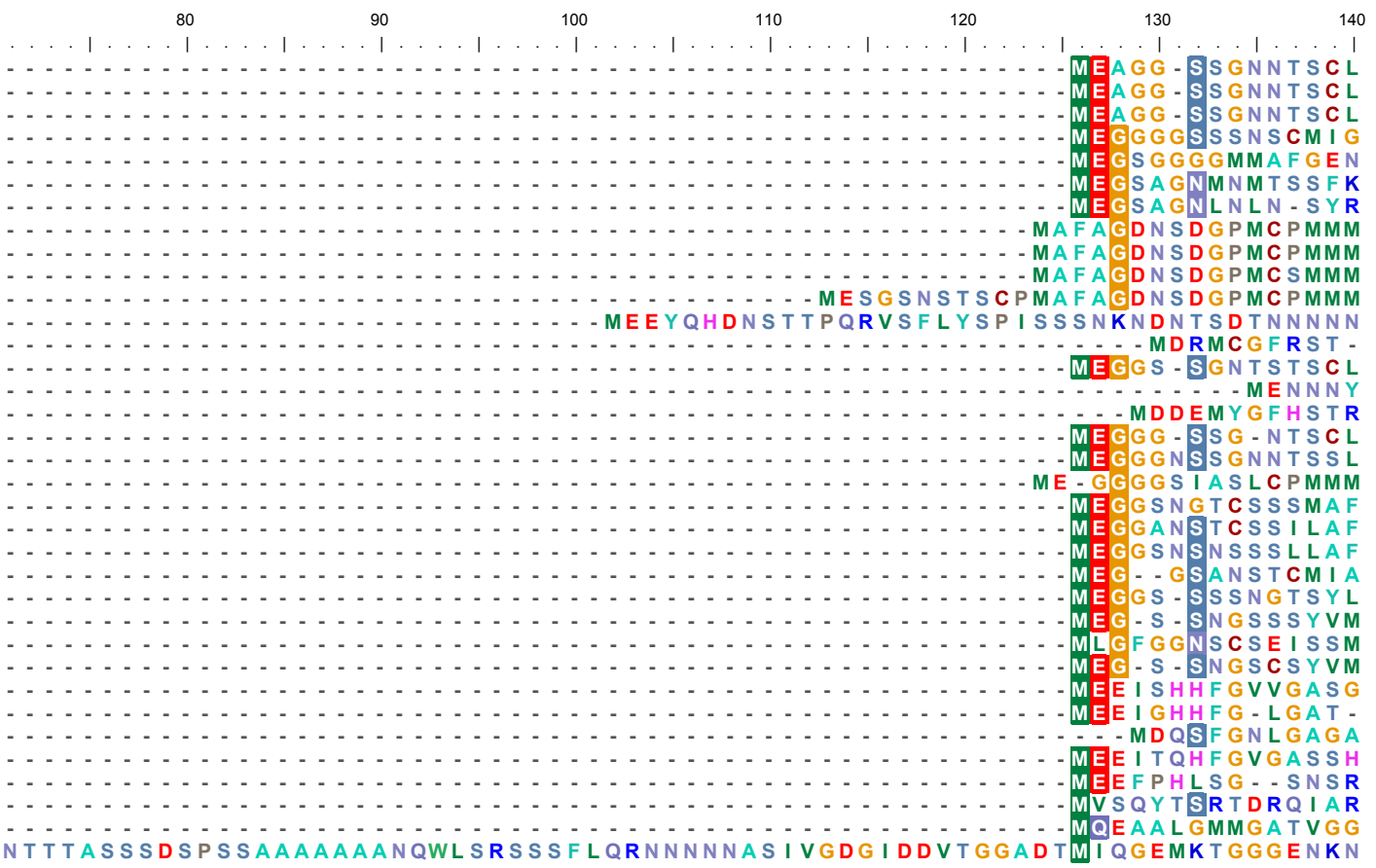




AbSTM
DuSTM
BcSTM
invaginata
hirzina
SrSTM
SsSTM
SHOOTMERISTEMLESS
BrSTM
BnSTM
ChSTM
KNAT1
KNAT2
LeT6
TKn1
POTH1
TobH1
PhSTM
InSTM
TmSTM
WsSTM
PsSTM
EeSTM
Sbh1
PsKn1
MtKNOX6
MtKNOX1
OSH1
HvKnox3
rs1
Kn1
AgaveKNOX1
EgKNOX1
KNAT7
KNAT3

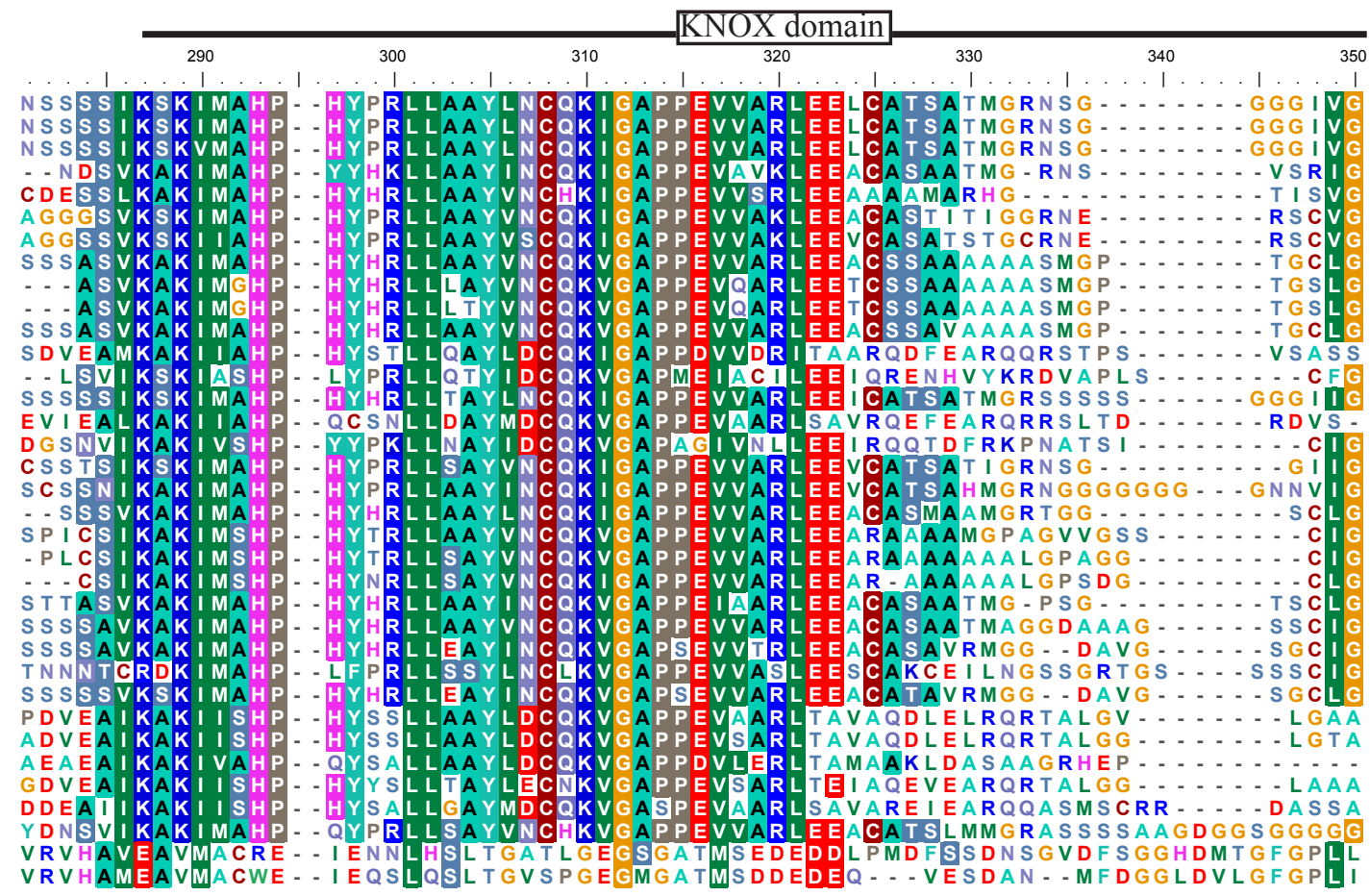

AbSTM
DuSTM
BcSTM
invaginata
hirzina
SrSTM
SsSTM
SHOOTMERISTEMLESS
BrSTM
BnSTM
ChSTM
KNAT1
KNAT2
LeT6
TKn1
POTH1
TobH1
PhSTM
InSTM
TmSTM
WsSTM
PsSTM
EeSTM
Sbh1
PsKn1
MtKNOX6
MtKNOX1
OSH1
HvKnox3
rs1
Kn1
AgaveKNOX1
EgKNOX1
KNAT7
KNAT3

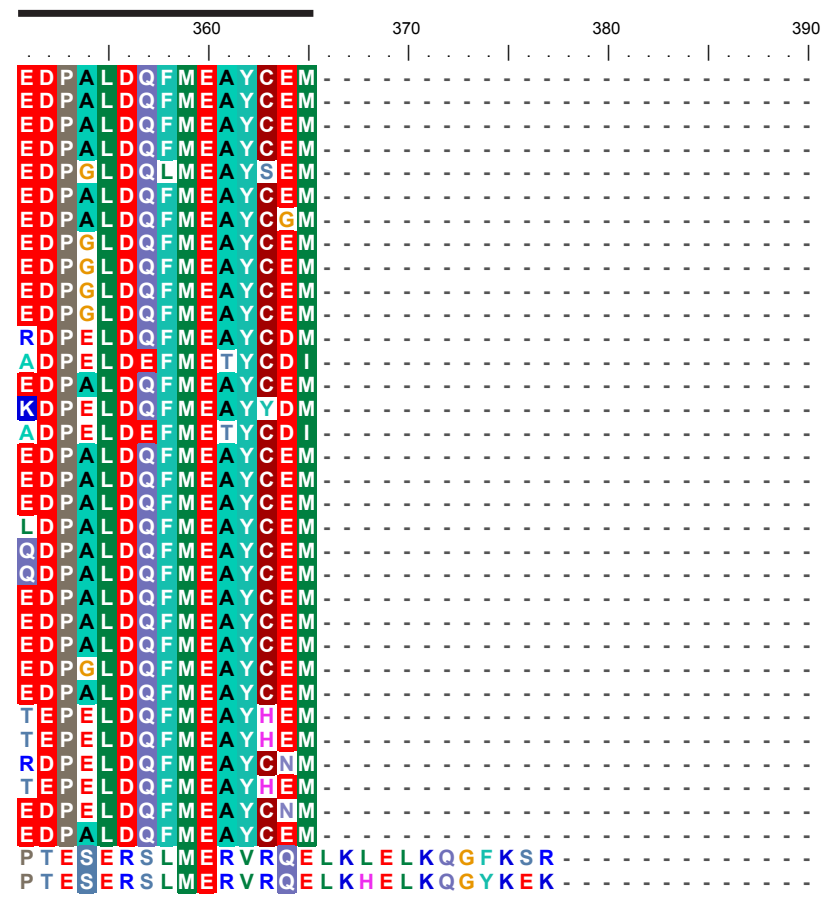


Supplemental figure 3. $A R P$ genes nucleotide alignment.

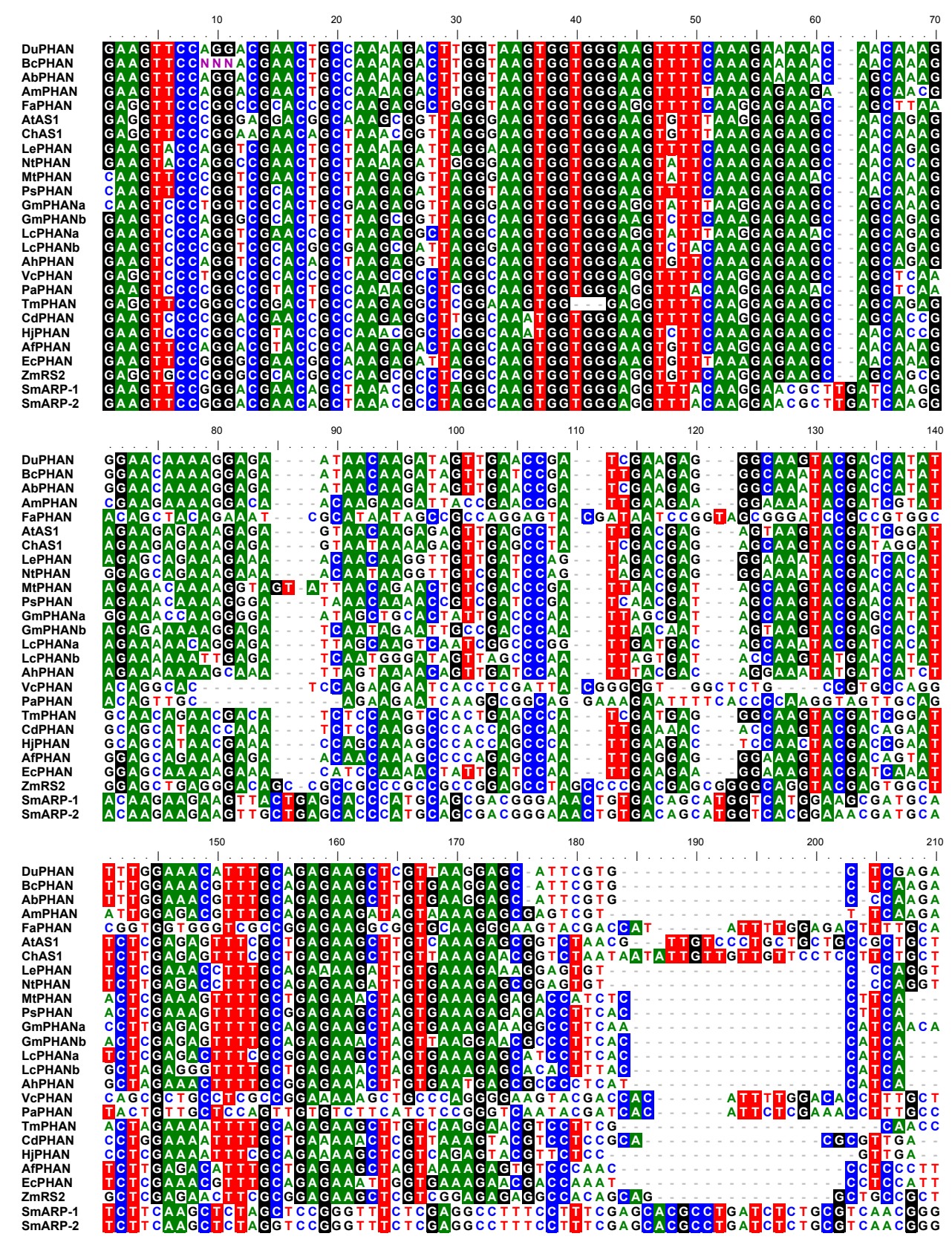




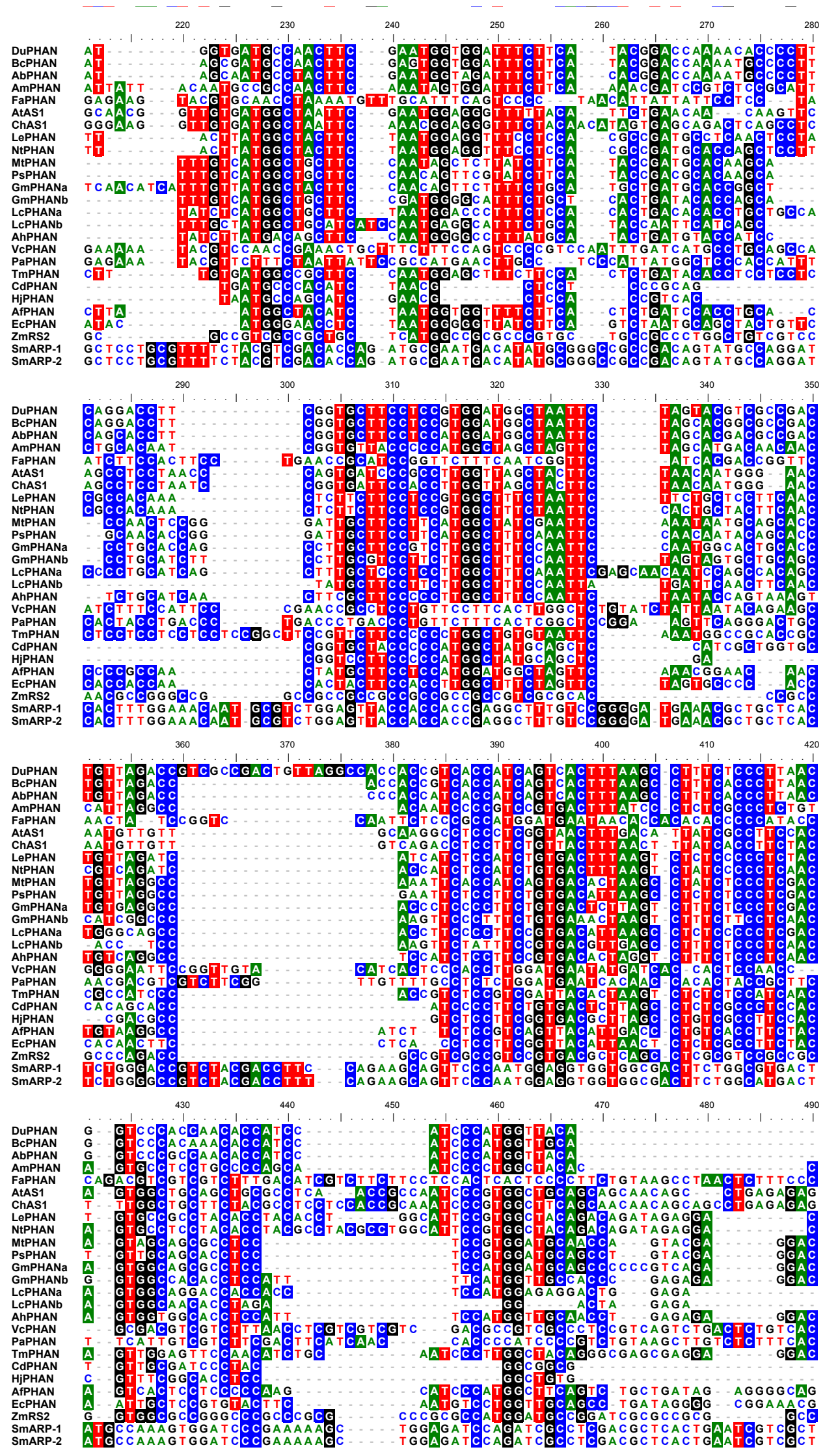



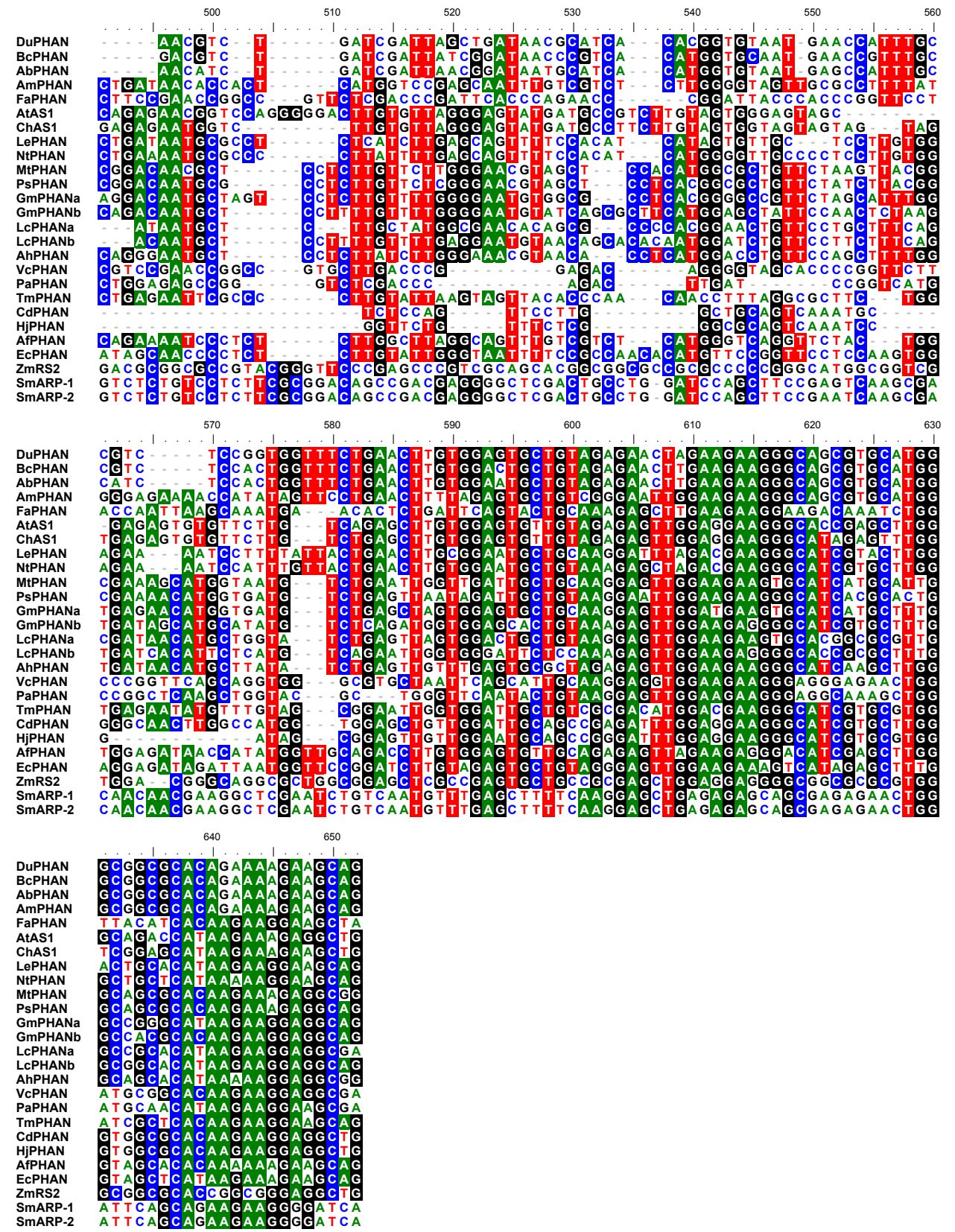
Supplemental figure 4. Deduced aminoacid sequence alignment of $A R P$ orthologs used to reconstruct the phylogeny of $A R P$. Black lines indicates part of the second MYB repeat.

MYB repeat

$10 \quad 20$

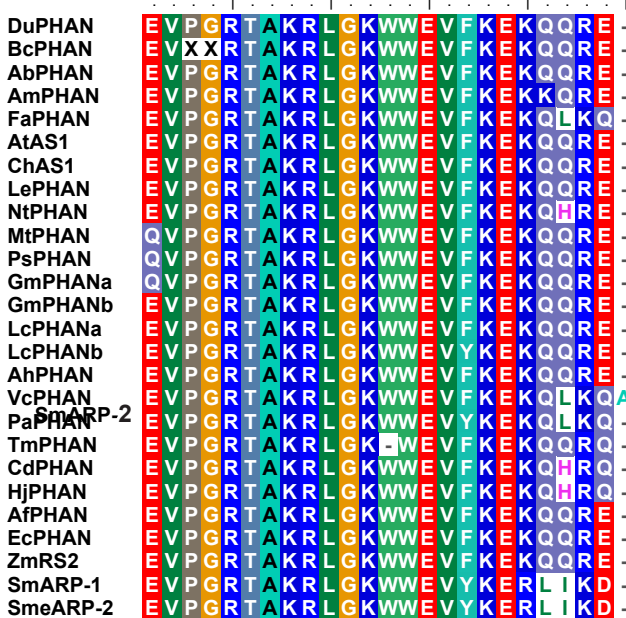

90

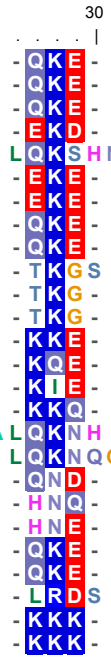

100

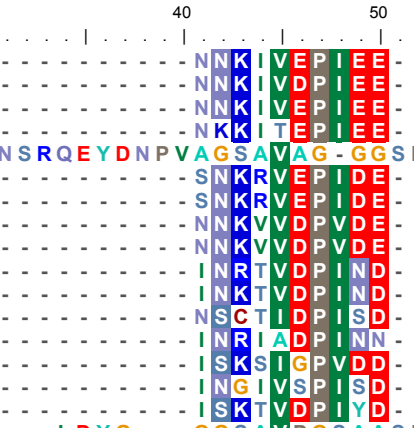

50

60

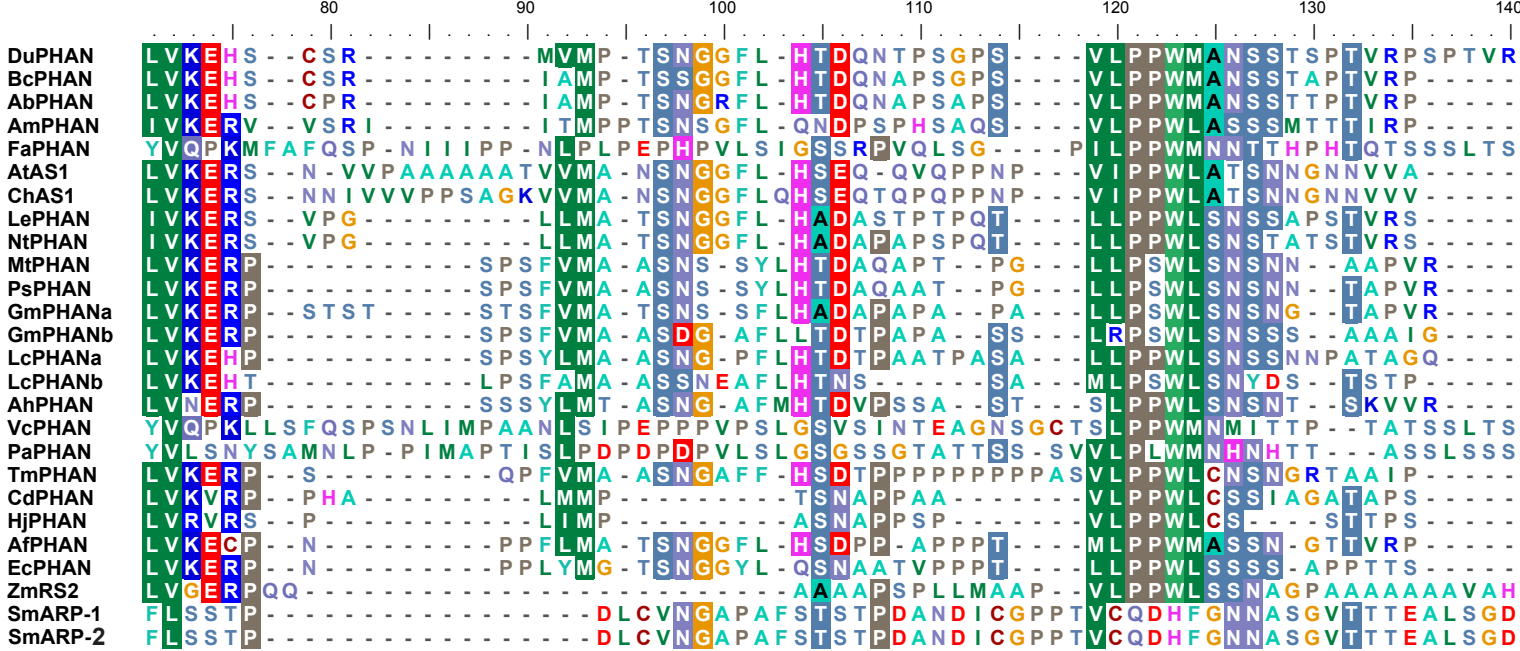

SmARP-2

160

180

190

200

DuPHAN

BcPHAN

AbPHAN

AmPHAN

FaPHAN

AtAS1

LePHAN

NtPHAN

MIPHAN

PSPHAN

GmPHAN

GmPHAN

LcPHANa

AhPHAN

VCPHAN

PaPHAN

TmPHAN

CdPHAN

HJPHAN

AfPHAN

EcPHAN

ZmRS2

SmARP-1

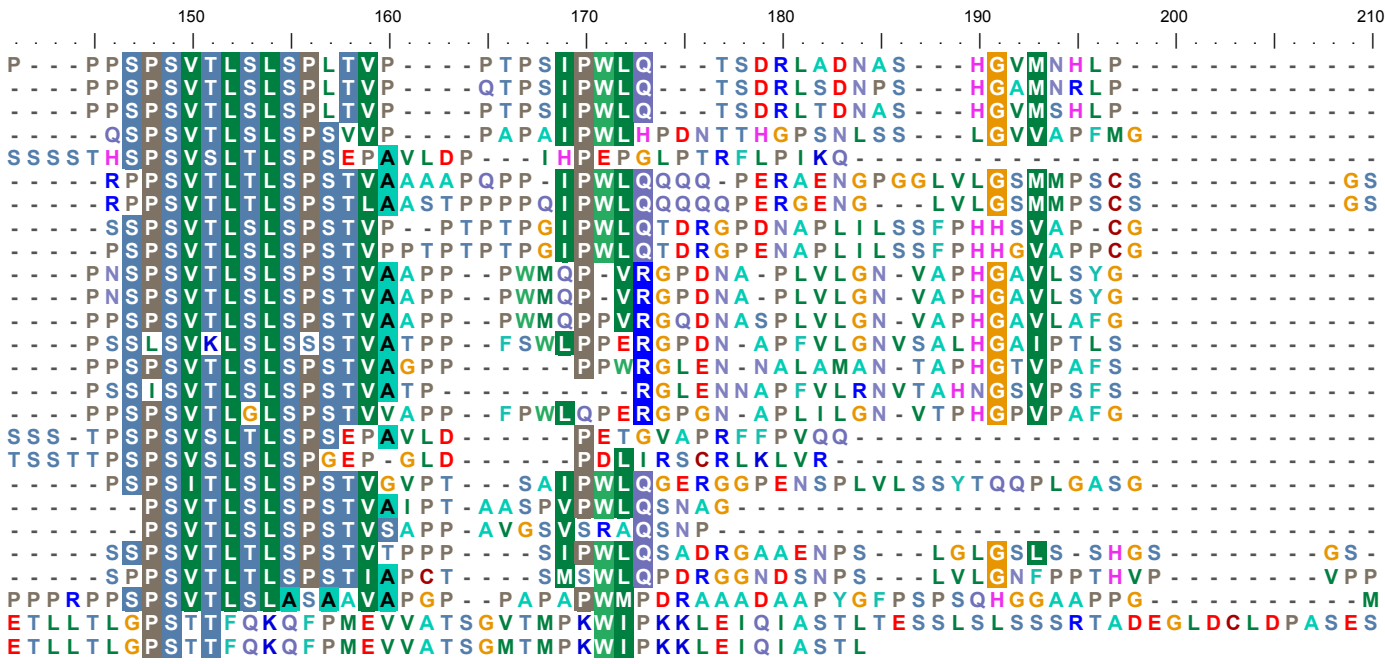


Supplemental figure 5. LEAFY/FLORICAULA nucleotide alignment.
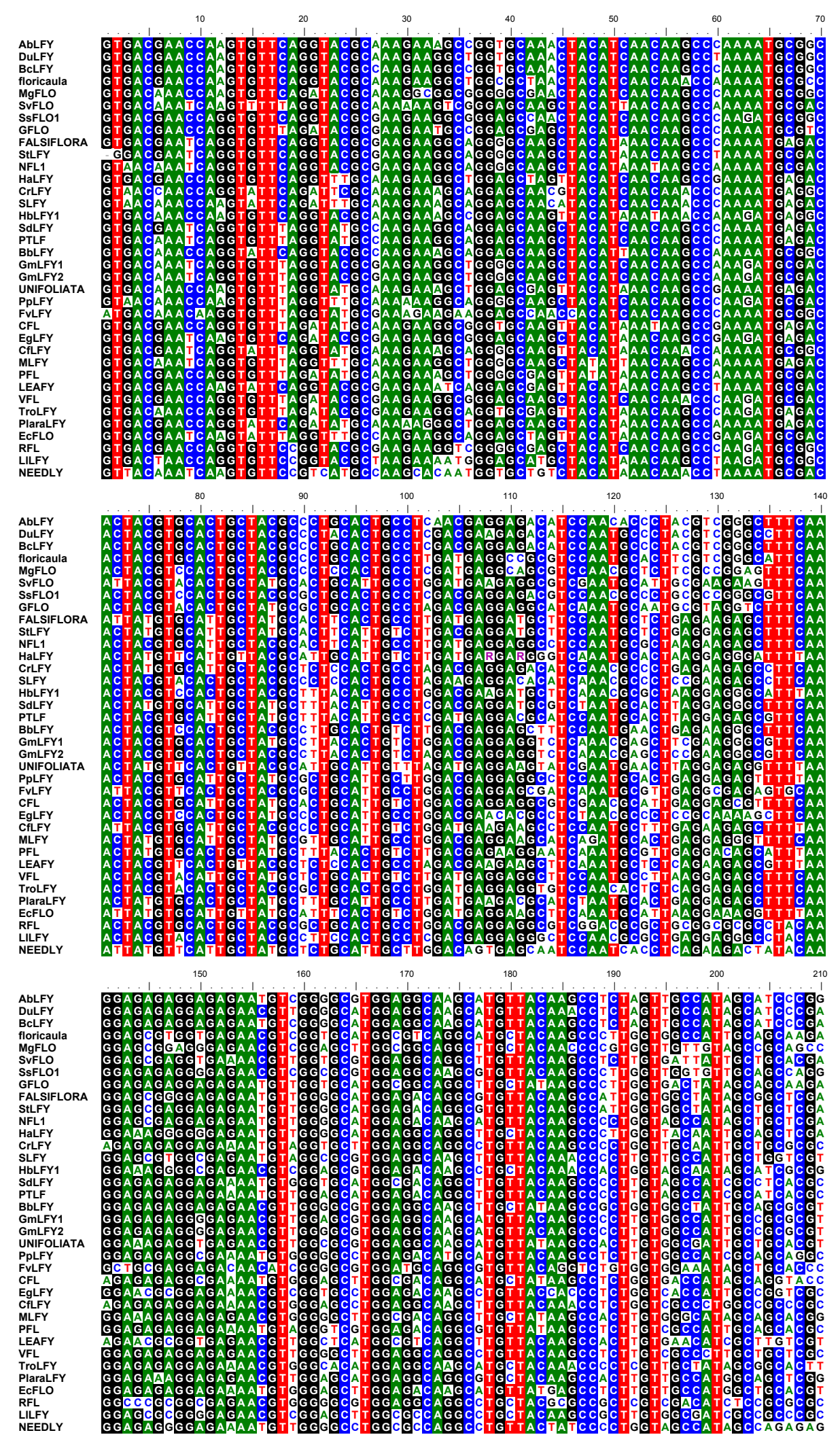

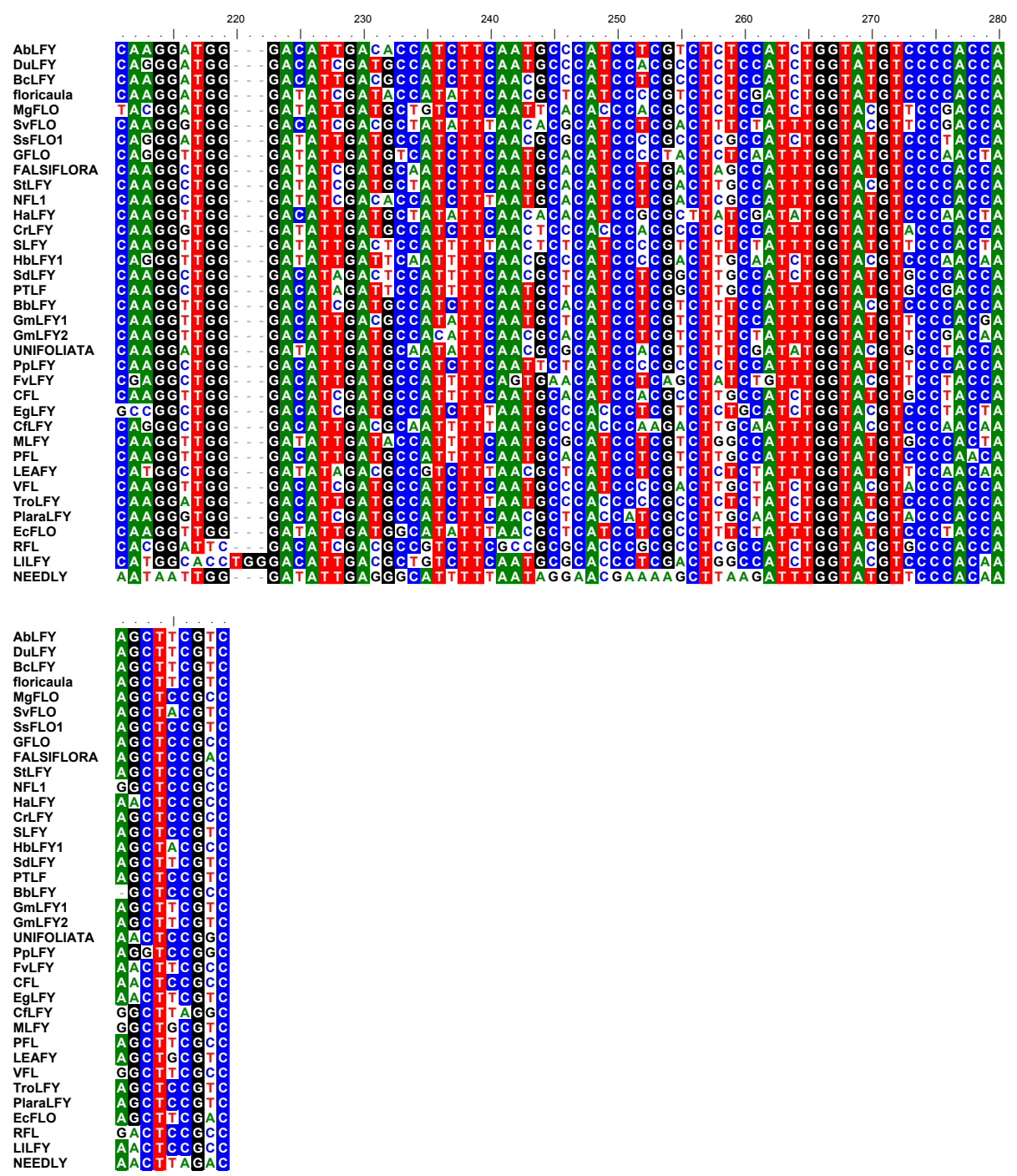
Supplemental figure 6. Deduced aminoacid sequence alignment of LEAFY/FLORICAULA orthologs used to reconstruct the phylogeny of $L F Y / F L O$.

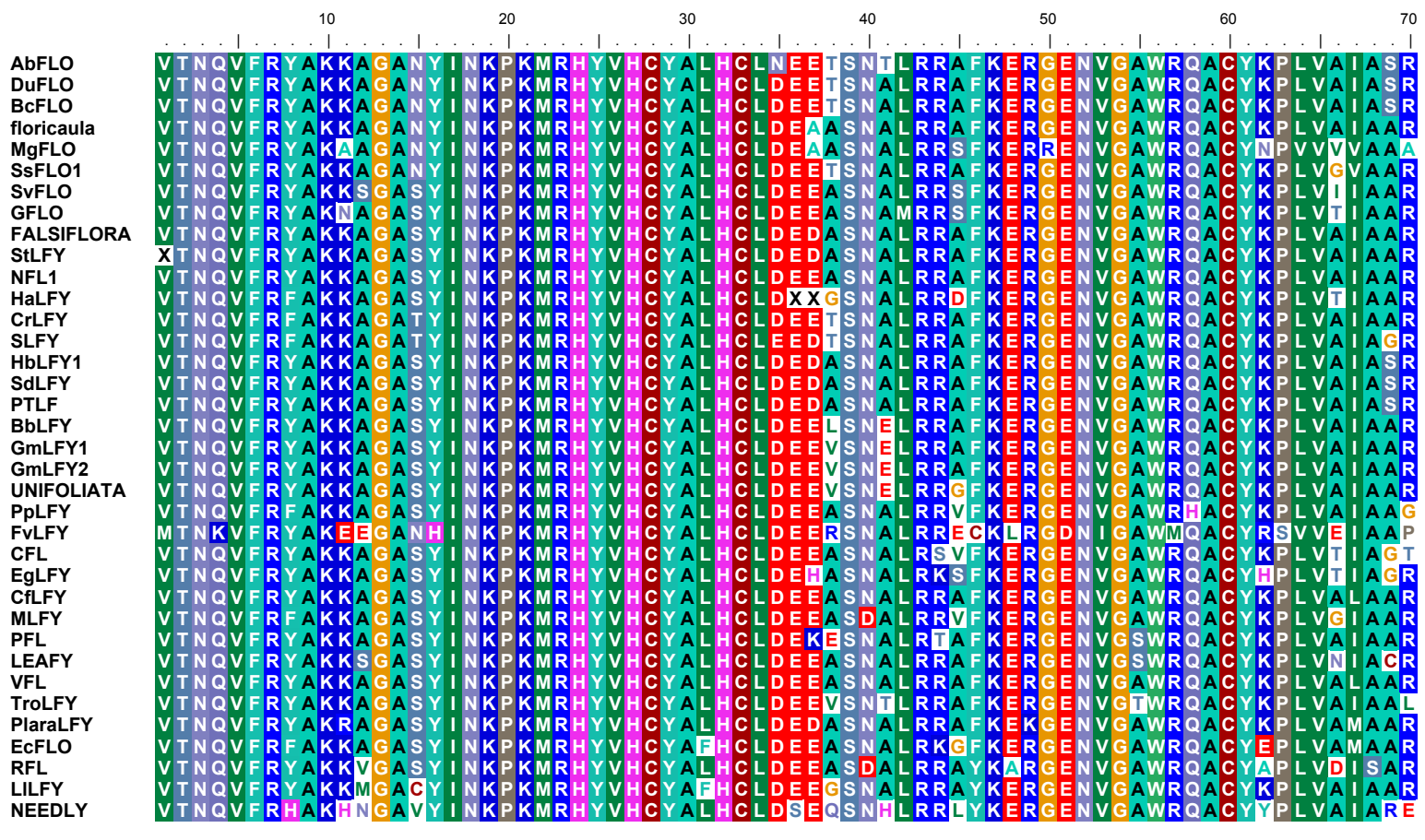

80

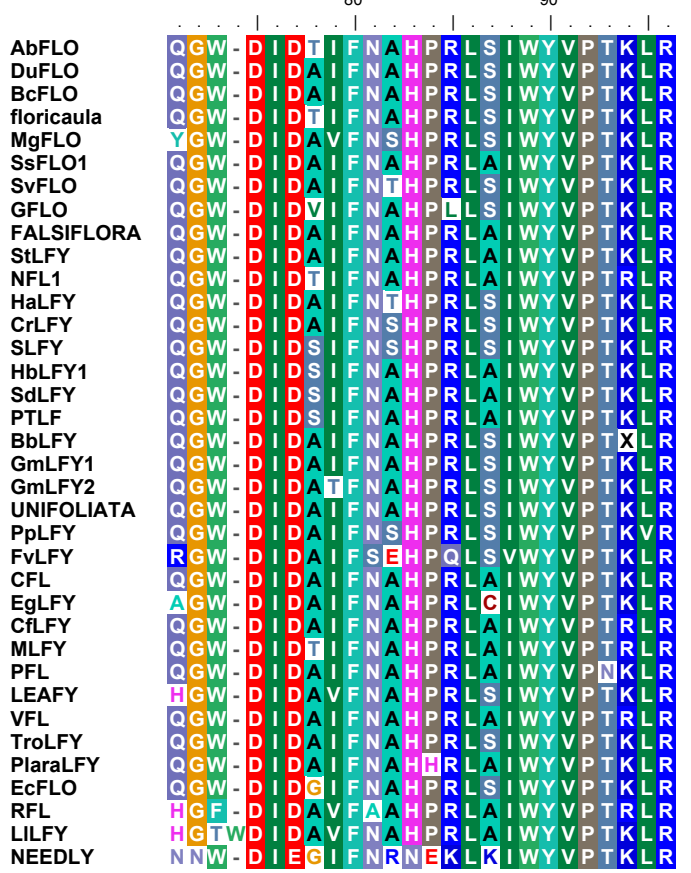




\section{Conlcusão Geral}

Plant's become climbers, in order, it may be presumed, to reach the light, and to expose a large surface of leaves to its action and to that of the free air. This is effected by climbers with wonderfully little expenditure of organized matter, in comparison with trees, which have to support a load of heary branches by a massive trunk.

Charles Darwin, 1865

"On the movements and habits of climbing plants" Journal of the Linnean Society of London 9: 1-118. 


\section{Conclusão Geral}

O objetivo desse estudo foi investigar a evolução dos diferentes tipos de gavinhas foliares encontrados em Bignonieae, bem como seu padrão de desenvolvimento, visando compreender como mudanças no padrão de desenvolvimento das folhas geraram a diversidade de tipos de gavinhas encontradas em Bignonieae atualmente. Para tal, analisamos os padrões evolutivos obtidos através de reconstruções de estados ancestrais do caráter "tipo de gavinha", bem como investigamos o desenvolvimento de gavinhas através de microscopia de varredura e secções anatômicas. Além disso, clonamos os ortólogos dos genes SHOOTMERISTEMLESS, PHANTASTICA e LEAFY/FLORICAULA em três espécies de Bignonieae com diferentes tipos de gavinhas, e analisamos o padrão de expressão destes genes durante o desenvolvimento das folhas, de forma a elucidar os genes envolvidos na regulação do desenvolvimento das gavinhas em Bignonieae.

O primeiro capítulo dessa tese foca nas reconstruções de estados de caracteres ancestrais e na análise do desenvolvimento de 11 espécies de Bignonieae, incluídas em 7 gêneros e representando espécies com gavinhas simples, trífidas e multífidas. Os estudos através de microscopia de varredura nos permitiram definir o padrão geral de desenvolvimento de folhas em Bignonieae, revelando que as folhas se desenvolvem de maneira acrópeta. Mais especificamente, estes estudos nos permitiram identificar a sequência de eventos que ocorre durante o desenvolvimento das folhas, definindo os estágios e as principais diferenças no desenvolvimento das folhas entre espécies com gavinhas simples e ramificadas. A interpretação dos padrões ontogenéticos de gavinhas à luz dos mapeamentos do caráter "tipo de gavinha" sobre uma robusta filogenia da tribo Bignonieae revelaram algumas tendências evolutivas interessantes. Mansoa e Dolichandra, gêneros que possuem gavinhas trífidas e são derivados de um ancestral direto que já possuía gavinhas trífidas, apresentam os ramos das gavinhas bem definidos no terceiro estágio de desenvolvimento. Diferentemente, Tanaecium pyramidatum, que também possui gavinhas trífidas, apresenta um atraso no desenvolvimento dos ramos da gavinha quando comparado à Mansoa e Dolichandra. Em T. pyramidatum, os ramos das gavinhas apresentam um desenvolvimento heterocrônico e se tornam claramente discerníveis apenas no sexto estágio de desenvolvimento. Além disso, foi observado que as folhas desta espécie apresentam características típicas de gavinhas simples 
durante o seu desenvolvimento, em particular uma precoce diferenciação da epiderme foliar, mescladas à características típicas de gavinhas ramificadas, como a atividade meristemática prolongada da região da blastozona localizada no ramo principal da gavinha. Desta maneira, concluiu-se que a presença de características típicas de gavinhas simples em uma espécie com gavinhas trífidas indica que o ancestral direto desta espécie possuía gavinhas simples, corroborando as reconstruções baseadas em ACCTRAN (parcimônia) e máxima verossimilhança. Além disso, as espécies de Bignonia estudadas apresentaram um padrão de desenvolvimento idêntico ao de Fridericia e Cuspidaria, gêneros com gavinhas simples bem estabelecidas, provenientes de ancestrais com gavinhas simples, e aninhados em um grande clado onde a grande maioria das espécies possui gavinhas simples. Assim, concluiu-se que embora o gênero Bignonia inclua um grande diversidade de tipos de gavinhas, o ancestral deste gênero provavelmente possuía gavinhas simples, também corroborando as reconstruções realizadas com base nos algoritmos ACCTRAN e máxima verossimilhança. De uma forma geral, os dados ontogenéticos corroboraram as reconstruções baseadas em ACCTRAN e máxima verossimilhança em quase todas as instâncias. Estas reconstruções indicam que o ancestral de Bignonieae, ou pelo menos do clado “core Bignonieae", possuía gavinhas trífidas, sugerindo que todos os outro tipos de gavinhas evoluíram a partir de um ancestral com gavinhas trífidas, através de mudanças na atividade da blastozona foliar, com uma cessação precoce da atividade da blastozona no caso das gavinhas simples, ou uma atividade mais prolongada da blastozona no caso das gavinhas ramificadas.

O segundo capítulo da presente tese focou na regulação gênica e origem das gavinhas foliares em Bignonieae. A espécie com gavinhas foliares mais estudada até o presente momento é Pisum sativum. Nesta espécie o desenvolvimento de folhas é exclusivamente regulado pelo gene $L F Y / F L O$, em contraste com todas as outras angiospermas analisadas até hoje, onde o desenvolvimento das folhas é regulado pelos genes $K N O X 1$. Este fato nos levou a hipotetizar que talvez as folhas de Bignonieae, também fossem reguladas exclusivamente pelos gene $L F Y / F L O$. Para elucidar essa questão, analisamos a expressão dos genes STM e LFY/FLO através de hibridização in situ em três espécies de Bignonieae com diferentes tipos de gavinhas. Detectamos que STM é expresso durante o desenvolvimento de folhas em Bignonieae, evidenciando que as folhas de Bignonieae e Pisum se desenvolvem de maneiras diferentes. Em Bignonieae, 
o gene STM é fortemente expresso nas regiões do primórdio foliar que estão se dividindo para formar as diversas partes da folha (p.ex., folíolos ou ramos das gavinhas). Assim, o padrão de expressão do gene STM em Bignonieae é similar ao padrão já documentado para outras plantas com folhas compostas, de forma que este gene provavelmente desempenha em Bignonieae a mesma função desempenhada em outras plantas espécies. Mais especificamente, este gene provavelmente atua de forma a prolongar a manutenção de um estado indiferenciado na blastozona foliar, permitindo uma maior elaboração da lamina foliar. O gene $L F Y / F L O$ também é expresso nas folhas em desenvolvimento de Bignonieae, num padrão que sugere que este gene pode estar envolvido na demarcação dos limites entre os primórdios foliares e o meristema apical caulinar, e também na delimitação dos órgãos que estão emergindo na blastozona foliar (p.ex., folíolos e ramos das gavinhas).

Neste segundo capítulo, também investigamos organização dos tecidos em todas as partes foliares, bem como a expressão do gene PHAN através de hibridização in situ durante o desenvolvimento das folhas, no intuito de averiguar a origem exata das gavinhas em Bignonieae. Em ervilha a origem das gavinhas ainda não está completamente esclarecida, com algumas teorias postulando que as gavinhas representam folíolos abaxializados. Assim, buscamos similaridades anatômicas entre as gavinhas e outras partes foliares, bem como buscamos identificar o plano de simetria de cada uma das partes da folha, no intuito de averiguar se os domínios adaxial e abaxial estavam presentes nas gavinhas. Concluímos que todas as partes da folha apresentam simetria bilateral, inclusive as gavinhas. Além disso, encontramos similaridades anatômicas entre as faces adaxial e abaxial da nervura central do folíolo e das respectivas faces na epiderme das gavinhas de D. unguis-cati. Detectamos também a formação de uma estrutura muito similar a estrutura de um folíolo jovem na ponta das gavinhas de A. buccinatorium. Interpretamos esses resultados como uma forte evidência de que as gavinhas de Bignonieae representam folíolos modificados. Ainda assim, para obtermos uma noção mais acurada sobre a delimitação dos domínios abaxial e adaxial em gavinhas de Bignonieae, investigamos o padrão de expressão de $P H A N$, e encontramos que este gene se expressa apenas nessa na porção adaxial da folha nos representantes de Bignonieae. Verificamos que o gene $P H A N$ apresenta um padrão de expressão polarizado em gavinhas ramificadas, se expressando apenas no domínio adaxial. Além disso, detectamos que o padrão de expressão do gene $P H A N$ é muito 
similar em folíolos e gavinhas de Bignonieae, representando mais um indício de que as gavinhas não representam folíolos abaxializados mas são, mesmo assim derivadas de folíolos em Bignonieae. Em $B$. callistegioides, que possui gavinhas simples, o gene $P H A N$ apresentou um padrão de expressão diferente, sendo expresso por todo o primórdio da gavinha, e não apenas no domínio adaxial. Esta variação no padrão de expressão do gene $P H A N$ em tipos diferentes de gavinhas parece estar relacionado com a formação polaridade nestes órgãos e possivelmente com o padrão de ramificação das gavinhas, visto que apenas gavinhas simples não apresentaram domínios adaxial e abaxial definidos. Assim podemos dizer que a presença de domínios abaxial e adaxial bem definidos são um pré-requisito para a ocorrência de ramificações em gavinhas e folíolos, corroborando a hipótese de que a justaposição entre os domínios adaxial e abaxial representa um pré-requisito para a expansão da lamina foliar. Verificamos também, que os genes PHAN e STM apresentam domínios de expressão que se sobrepõe espacial e temporalmente durante o desenvolvimento de folhas em Bignonieae, da mesma forma como ocorre em outras espécies com folhas compostas.

Este estudo evidenciou que abordagens integrativas, com a utilização de dados de várias naturezas, como morfológicos, anatômicos, ontogenéticos, e de regulação gênica, aliados as reconstruções de estados ancestrais de caráter, podem contribuir grandemente para um melhor entendimento da história evolutiva de características morfológicas. Além disso, abordagens integradas como esta nos permitem identificar os processos evolutivos responsáveis pelo surgimento da diversidade fenotípica. Neste estudo, os dados ontogenéticos trouxeram novas evidências que corroboraram algumas reconstruções de caracteres ancestrais em detrimento de outras, de forma a esclarecer alguns pontos de ambiguidade gerados nas reconstruções de caracteres ancestrais. $\mathrm{O}$ fato dos dados ontogenéticos sustentarem algumas hipóteses de evolução dos diversos tipos de gavinhas mas não outras, demonstrou a importância de estudos integrados para a elucidação de padrões de evolução de caracteres.

Outro ponto importante desse estudo foi o estabelecimento de uma arcabouço de conhecimento sobre o desenvolvimento de folhas em Bignonieae. Utilizando várias abordagens, delimitamos os estágios de desenvolvimento em folhas com diferentes tipos de gavinhas, bem como confirmamos que as gavinhas são de fato folíolos modificados. Além disso, elucidamos que as folhas de Bignonieae se desenvolvem de 
maneira acrópeta e, diferentemente de ervilhas, apresentam um desenvolvimento controlado por genes KNOX1. Estes dados evidenciam que aparentemente não existe nenhuma relação entre a ausência da expressão do KNOX1 no desenvolvimento foliar e no surgimento de gavinhas foliares. Esse conhecimento não somente servirá como base para outros estudos abordando o desenvolvimento de folhas na família Bignoniaceae como um todo, como também servirá como base para estudos comparativos entre gavinhas foliares de outros grupos de plantas (p.ex., Polemoniaceae, Asteraceae, Bignonieae e ervilhas). Além disso, os padrões de expressão encontrados para o gene PHAN em Bignonieae evidenciam que gavinhas foliares em Bignonieae podem representar outro excelente sistema para o estudo de genes e mecanismos envolvidos no estabelecimento da polaridade de órgãos em geral.

Apesar de termos demonstrado neste estudo que alguns genes, já conhecidos por regular o desenvolvimento de folhas compostas em outras espécies de angiospermas, também se expressam durante o desenvolvimento de folhas em Bignonieae, a função destes genes só poderá ser confirmada através de estudos envolvendo silenciamento gênico. Testes preliminares mostraram que é possível utilizar o VIGS, Virus Induced Gene Silencing (i.e., silenciamento gênico pós-transcricional empregando vetores virais) em Dolichandra unguis-cati, abrindo novas possibilidades para o silenciamento gênico de representantes da tribo Bignonieae. Além disso, já existem protocolos de cultura de tecidos e transformação por Agrobacterium disponíveis para Tecomella, outro representante da família Bignoniaceae. Embora nem sempre espécies aparentadas respondam bem a um mesmo protocolo de cultura de tecidos e transformação, os protocolos existentes para Tecomella servirão como um ponto de partida para o desenvolvimento de tais protocolos para plantas da tribo Bignonieae. 


\section{CAPA}

A ilustração da capa da tese contém uma mescla de imagens incluindo desenhos feitos por George Darwin (1, 2, 4, 5, 6, 8, 9, 11 e 13, seguidas da legenda original) para o ensaio "On the movements and habits of climbing plants" de Charles Darwin publicado em 1865, Journal of the Linnean Society of London 9: 1-118, e imagens desta tese.

1: Clematis glandulosa, with two young leaves clasping twigs, with the clasping portions thickened.

2: Smilax aspera.

3: Dolichandra unguis-cati, seção tranversal do ramo principal da gavinha, porção abaixo da ramificação.

4: Solanum jasminoides, section of a petiole some weeks after it had clasped a stick.

5: Solanum jasminoides, with one of its petioles clasping a stick.

6: Vitis vinifera. Flower-tendril, with a scale at its base.

7: Dolichandra unguis-cati, seção tranversal do peciólulo foliolar.

8: Ampelopsis hederacea. Tendril, several weeks after its attachment to a wall, with the branches thickened and spirally contracted, and with the extremities developed into disks. The unattached branches have withered and dropped off.

9: Corydalis claviculata. Leaf-tendril, of natural size.

10: Bignonia callistegioides, micrografia de varredura mostrando os primórdios foliares nos estágios 1 e 2.

11: Bignonia. Unnamed species from Kew.

12: Amphilophium buccinatorium, seção sagital. Figura mostrando a hibridização in situ de RNA do gene AbPHAN, ortólogo do PHANTASTICA de Antirrhinum majus em A. buccinatorium.

13: Ampelopsis hederacea. Tendril, with the young leaf.

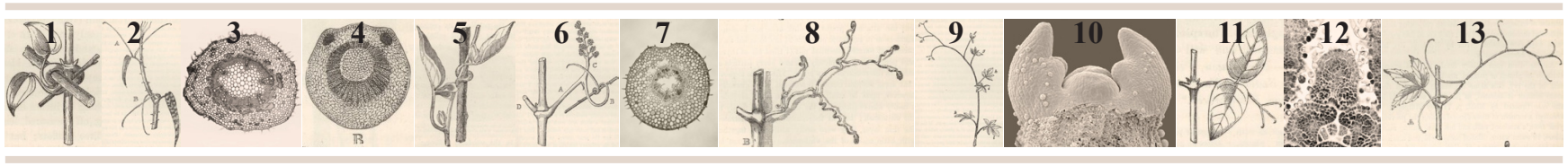


